This item was submitted to Loughborough's Research Repository by the author.

Items in Figshare are protected by copyright, with all rights reserved, unless otherwise indicated.

\title{
A practical assessment of spraying and welding processes for the hard- facing of grey cast iron
}

PLEASE CITE THE PUBLISHED VERSION

\section{PUBLISHER}

(c) D. Womersley

\section{PUBLISHER STATEMENT}

This work is made available according to the conditions of the Creative Commons Attribution-NonCommercialNoDerivatives 2.5 Generic (CC BY-NC-ND 2.5) licence. Full details of this licence are available at: http://creativecommons.org/licenses/by-nc-nd/2.5/

\section{LICENCE}

CC BY-NC-ND 2.5

\section{REPOSITORY RECORD}

Womersley, D.. 2019. "A Practical Assessment of Spraying and Welding Processes for the Hard-facing of Grey Cast Iron”. figshare. https://hdl.handle.net/2134/26955. 


\section{LLoughborough University}

This item was submitted to Loughborough University as an MPhil thesis by the author and is made available in the Institutional Repository (https://dspace.Iboro.ac.uk/) under the following Creative Commons Licence conditions.

\section{Ccreative \\ $\begin{array}{lllllllllllllllllllll}\mathrm{C} & \mathrm{O} & \mathrm{M} & \mathrm{M} & \mathrm{O} & \mathrm{N} & \mathrm{S} & \mathrm{D} & \mathrm{E} & \mathrm{E} & \mathrm{D}\end{array}$}

Attribution-NonCommercial-NoDerivs 2.5

You are free:

- to copy, distribute, display, and perform the work

Under the following conditions:

Attribution. You must attribute the work in the manner specified by the author or licensor.

Noncommercial. You may not use this work for commercial purposes.

No Derivative Works. You may not alter, transform, or build upon this work.

- For any reuse or distribution, you must make clear to others the license terms of this work.

- Any of these conditions can be waived if you get permission from the copyright holder.

Your fair use and other rights are in no way affected by the above.

This is a human-readable summary of the Leqal Code (the full license).

Disclaimer

For the full text of this licence, please go to: http://creativecommons.org/licenses/by-nc-nd/2.5/ 


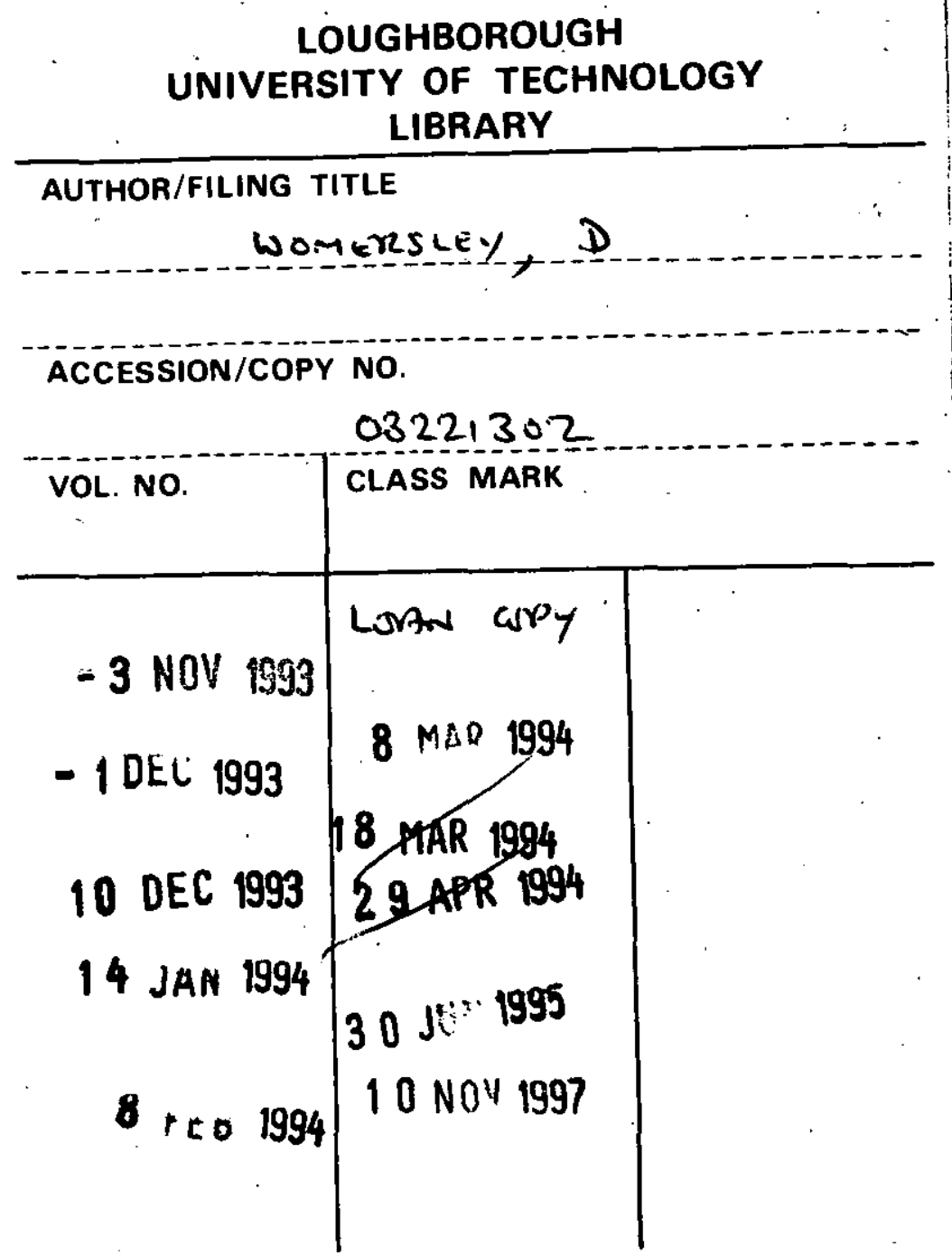





\section{A PRACTICAL ASSESSIENT OF SPRAYIIG AND WELDIMG PROCESSES FOR THE HARDFACING OF GREY CAST IRON}

by

D. WOMERSLEY

A thesis submitted in partial fulfilment of the requirements for the award of the degree of viaster of Philosophy of the Loughborough University of Tecinnology

Harch 1988

(C) D. WOMERSLEY 1988 
Loughborough iniveretty

of Technotogy Utbreny

Ins 89


ACKNOWLEDGEMENTS 


\section{Acknowledgements}

The author wishes to thank the following:

Dr. N. P. Fletcier, acting Director of the Centre for Industrial Studies, for his permission to undertake the investigation, also for his help and encouragement.

Dr. A. J. Clegg, for his guidance, advice and encouragement.

Mr. R. E. Phelps, for his continual support.

Technical Tutors in the Centre for Industrial studies especially Mr. C. Wood and Mr. G. Corliss for their expertise in casting and grinding.

Technicians Mr. D. Hurrell and N.r. T. Smith for their help with the photography. 
CONTENTS 


\section{CONTEITS}

$\underline{I t \in m}$

Page ĩo.

Synopsis

Introduction

CLAPTER 1

Literature Survey

1.1 Hardfacing

1.1.1 Reasons for Hardiacin $\mathbb{B}$

1.2 Wickel-Base Alloys

1.2.I Applications of the ifickel-Base Alloys

1.2.2 Nickel - Chromium - Boron jardfacing

$$
\text { Alloys }
$$

1.2.3 Expansion and Contraction ô $\mathrm{Ni}-\mathrm{C} . \mathrm{-}-\mathrm{B}$

$$
\text { Alloys }
$$

1.3 Grey Cast Iron BS 1452: 1977

1.3.1 Expansion and Contraction of Grey Cast Iron

1.3.2 Apolications of Grey Cast Iron

1.3.3 Preparation of Grey Cast Iron Prior to Hardfacing

1.3.4 Preheating of Grey Cast Iron Prior to Hardfacing

1.4 Spraying and Welding Processes

1.5 Dilution

1.6 Hear

1.6.1. Abrasive Wear

1.6.2 Classification of Abrasive viear

1.6.3 Abrasive ilear of $\mathrm{Ni}-\mathrm{Cr}-\mathrm{B}$ Hardiacing Allioys 
1.7.1 Fume Extraction and Ventilation 26

1.7.2 Respiratory Hazards. 27

1.7.3 Equipment Safety $=7$

1.7.4 Personal Protection 27

1.8 Summary of Literature Survey

1.j.I Grey Cast Iron Substrate ¿8

1.8.2 Ni - Cr - B Harafacing Alloy 29

1.3.3 Spraying anc "̈elding Processes 29

$\begin{array}{lll}1.3 .4 & \text { Safety } & 30\end{array}$

CHAPTER 2

Spraying and "relding Processes 31

2.1 Thermal Spraying 31

2.1.I Operating Tecinique 31

2.1.2 Fusing Tecinnique $\quad 35$

2.2 Powder Spray Helding 37

Z.E.I Operating Technique 39

2.3 oxy-acetylene relding 40

2.3.1 Operating Technique 40

2.4 Tungsien Inert Gas Helding 42

2.4.1 Operating Technique 42

CHAPTER 3

Experimental Work 44

3.1 Aorasive :Hear Testing 44

3.2 Hardness Testing 50

3.2.1 Surface Hardness 50

3.Ż.2 Macro hardiness 50

3.3 Optical ivicroscopy

3.4. Electron probe licroanalysis 52

3.5 Preparation of Specimens for Hardiacing

Experiments 
3.5.1 Production of the Substrate

3.5.2 Preparation of the substrate suriace

3.6 Mardiacing operations

3.6.1 Thermal Spraying

54

3.6́.2 Powder Spray ":elding 56

3.6.3 Oxy-acetylene :Eldine 57

3.6.4 Tungsten Inert Gas "elding 58

3.? Surface Grinuing Deposition

CHAPTER 4

Results

4.1 Abrasive "year Test Results

4.1.1 Control Data

4.1.2 Hardifacing Processes

4.1.3 Comparative Results Presentation

4.2 Surface Hariness Test Results

4.3 Macro Hardness Profile Fesults

4.4 Electron Probe Microanalysis

4.5 Optical Microscopy

\section{CHAPTER 5}

Discussion of the Results

5.1 Abrasive :fear Tesing

5.1.1 Control Specimens

128

5.1.2 Hardiaced Surfaces

5.1.3 Statistical Analysis of vear Test Results 137

5.2 Surfece Hartness Testing

5.2.1 Statistical Analysis of Surface Hardness. Results

5.3 Macro Hardness Profile Tests

5.4 Electron probe :icroanalysis

5.5 Optical Microscopy. 
5.6 Operator Factor 147

5.6.1 Thermal Spraying 147

5.6.2 Powder Spray ::elding 148

5.6.3 Oxy-acetylene

5.6.4 Tungsten Inert Gas :ielding 148

5.7 Discussion Sumary $\quad$ I49

CHAPTER 6

Conclusions 152

CHAFTER ?

Suggestions for Further Vork 155

$\begin{array}{ll}\text { REFEREIICES } & 157\end{array}$

APPEIDICES

1. Derivation of Uear Volume Formula for Reciprocating Diamond Tests - 162

2. Wear Volume Vs Load Detailed Results 164

3. Wacro Hardness Profile Detailed Results 200

4. Electron Probe Microanalysis Detailed Reslilts 204

5. Wethod for Statistical Analysis of Hear and Surface. Hardness Test Results. 236 


\section{IIST CE TAELES}

Table ilo.

Page iio.

I. Deposit Thickness and Dilution

2. Thermai Spraying Tables for lietco Type $2 P$ Thermospray Gun

3. Travel Speeds

4. Regulator Pressure Settings and hozzle Sizes

5. Grey Cast Iron 10 Scratches.

6. Grey Cast Iron 50 Scratches.

7. Grey Cast Iron 100 Scratches

8. Grey Cast Iron 500 Scratches.

9. Thermal Spraying

1 Layer Deposit

10 Scratches

10. Thermal SEräying

2 Iayer Deposit

10 Scratches

11. Thermal spraying

I Layer Deposit

50 scratches

12. Thermal sprayine

2 Layer Deposit

50 scratches

13. Thermal spraying

1 Layer Deposit

100 scratcines.

14. Thermal Spraying

2 Layer Deposit

100 Scratcines.

15. Thermal spraying

I Layer Deposit

500 Scratches

16. Thermal Sprajing

2 Layer Deposit

500 scratches

17. . Powder spray Helding

1 Layer Deposit

10 Scratches

18. Powder spray welding

2 Layer Deposit 
19. Powder spray thelding

1 Layer Deposit

50 Scratches

20.. Powder Spray $\because e l d i n \Xi$

2 Layer Deposit

50 Scratches

21. Powder Spray :telding

1 Layer Deposit

100 Scratches

22. Powder Spray "Jelding

2 Layer Deposit

100 Scratches

23. Powder Spray ilelding

1 Layer Deposit

500 Scratches.

24. Powder Spray Welding

2 Layer Deposit

500 scratches

25. Oxy-acetylene Welding

1 Layer Deposit

10 scratches

25. Oxy-acetylene Helding

2 Layer Deposit

10 Scratches.

27. Oxy-acetylene ielding

1 Layer Deposit

50 Scratches

28. Oxy-acetylene "yelding

2 Layer Deposit

50 scratches

29. Oxy-actjlene velding

1 Layer Deposit

100 Scratches

30. Oxy-acetylene Wielding

2 Layer Deposit

100 Scratches.

31. Oxy-acetylene :Ielding

1 Lajer Deposit 500 scratches

32. oxy-acetylene :ielding

2 Layer Deposit

- 500 scratches

33. Tungsten Inert Gas \#̈lding I Layer Deposit I0 Scratches 
34. Tungsten Inert Gas :":elding

$乏$ Layer Deposit

10 Scratches

35. Tunesten Inert Gas Welding

1 Layer Deposit

50 Scratches

36. Tungsten Inert Gas Heloing 2 Layer Deposit 50 Scratches

37. Tungsten Inert Gas ":elding

1 Layer Deposit 100 Scratches.

38. Tungsten Inert Gas Welding

2 Layer Deposit 100 Scratches

39. Tungsten Inert Gas. Wel ding

1 Layer Deposit 500 Scratcines

40. Tungsten Inert Gas WeIding

2 Layer Deposit 500 scratches.

41. Thermal Spraying

Surface Hardness. 106

42. Powder Spray Welding Surface Hardness 107

43. Oxy-acetylene "yelding Surface Hardness. 1.08

44. Tungsten Inert Gas. Welding Surface Hardness

45. Thermal Spraying

1 Layer Deposit

Macro Hardiness

46. Thermal Spraying

2 Layer Deposit Nacro Hardness

47. Powder spray Vielding

1 Layer Deposit

Macro Hardness.

48. Powder Spray Welding

2 Layer Deposit Hacro Hardness.

49. Oxy-acetylene Welding

1 Layer Deposit

- Hacro hardness

50. oxy-acetylene $\because e l d i n g$

2 Layer Deposit 
5I. Tunesten Inert Gas Helding 1 Lajer Deposit Yiacro Hardiness

52. Tunesten Inert Gas Hacro Hardness

53. Electron Probe Microanalysis Approxinate Percentage ini

54. Electron Probe Microanalysis Approximate Percentage $\mathrm{Cr}$

55. Electron Proce licroanalysis Approximate Percentage Si

56. Electron Probe Microanalysis Approximate Percentage $\mathrm{Fe}$

57. Relative Percentäges of ":ear Thermal Sprajing 130

58. Relative Percentages of ilear Powder Spray Welding

59. Relative Percentages of Hear Oxy-acetylene Welding

60. Relative Percentages of Hear Tunfsten Inert Gas Welding

61. I Layer and 2 Layer Deposits Relative to The Cast Iron Substrate

62. 2 Layers Relative to 1 Layer Deposits

63. Statistical Analysis of l.:ear Test Results. One Layer Comparisons

64. Statistical Analysis of $\because$ ear Test Results Two Layer Comparisons

65. Statistical Analysis of Mear liest Results - One Layer Vs Two Layer Comparisons

66. Statistical Significant Differences 


\section{IIST OF PLATES}

Plate No.

Page No.

2. 1 Separation of Depositec Coating

2. Separation of Fused Coating 37

3. I Reciprocating Diamond Scratch Testing Vachine 47

4. I Thermal Spraying licrostructure. I

4. 2 Thermal Spraying Microstructure 120

4. 3 Thermal Spraying Interface unetched 121

4. 4 Thermal Spraying Interiace Etcined I2I

4. 5 Powder spray WeIding licrostructure I22:

4. 6 Powder Spray Welaing Microstructure I22

4. 7 Powder Spray "̈elding Interface unetched I23:

4. 8 Powder Spray Heldin Interface Etched I23:

4. 9 Oxy-acetylene :ielding Nicrostructure I 24

4.10 Oxy-acetylene Welding Microstructure 124 .

4.11 Oxy-acetylene Welding Interface Unetched I25

4.12 Cxy-acetylene Welding Inter face Etched 125

4.13 Tungsten Inert Gas Welding Microstructure I:26:

4.14 Tungsten Inert Gas Welding Microstructure 126

4.15 Tungsten Inert Gas Welding Interface Unetched I27.

4.16 Tungsten Inert Gas Welding Interface Etched I27. 


\section{IIST OF FIGURES}

Figure ĩo.

Pase ño.

1. I Undercutting

1. 2 Rough Threading

1. 3 Overlapping Technique

2. 1 Hetco Type 2p.Thermospray Gun

2. 2 Carourizing Flame

2. 3 Powder Spray \#elding Blowpipe

2. 4 Angle of Hardfacing Rod and Blowpipe

2. 5 Preparation of the Tungsten Electrode

3. I Detail of Diamond Scratch Testing

3. 2 Cutting Procedure for Test specimens

3. 3 Derivation of llear Volume

3. 4 Measurement of Scratch Width

4. I Wear. VoIume Vs Load Grey Cast Iron

4. 2 Wear Volume Vs Load Thermal Spraying 10 Scratches.

4. 3 Wear Volume Vs Load Thermal Spraying 50 scratches

4. 4 Wear Volume Vs Load Thermal Spraying 100 Scratches

4. 5 Wear Volume. Vs Load Thermal Spraying 500 scratches

4. 6 "iear Volume Vs Load Powder Spraying

10 Scratches

4. 7 Wear Volume Vs Load Powder Spraying 50 scratches

4. 8- Hear Volume Vs Load powder Spraying 100 Scratches. 
4. 9 :: vear Volume Vs Load Dowder Spraying

500 scratcines

4.10 :iear Volume is Load Oxy-acetylene

10 Scratches

4.11 Wear Volume is Load Oxy-aceiylene

50 Scratches

4.12 Wear Volime Vs Load Oxy-acetylene

100 Scratcines

4.13 Hear Volume Vs Load Oxy-acetylene

500 Scratches

4.14 Wear Volume Vs Load Tungsten Inert Gas

10 Scratches.

4.15 Wear Volume Vs Load Tuigsten Inert Gas

50 Scratches

4.16 Wear Volume Vs Load Tungsten Inert Gas 100 Scratches

4.17 Vear Volume Vs Load Tungsten Inert Gas 500 Scratches

1 Layer Deposits

10 Scratches.

102

4.19

2 Layer Deposits

Io scratches.

102

4.20 1 Layer Deposits

50 scratcies

.103

4.21

2 Layer Deposits

50 Scratches

.103

4.22 1 Layer Deposits 100 Scratches

.104

4.232 Layer. Deposits 100 Scratches

.104

4.241 Layer Deposits 500 scratches

1.05

4.25 2 Layer Deposits 500 Scratches.

4.26 HV Vs Depth of Coating Thermal Spraying

- Macro Harciness 
4.27 WI Vs Deptin of Coating Powder Spray

WeIding Hacro Eardness

4. 33 tIV Is Degth of Coatine Oxy-acetylene

:.elaiñ i.acro Larciness

4.29 Hy Vs bepth of Coatine Tungsten Inert Gas

$\because$ :Iding llacro Harciness 


\section{APPEMDICES}

\section{LIST OF TADIES}

pable lio.

Dage i:io.

I. Wear Volume is Load Grey last Iron

10 Scratches.

164

2. Wear Volume Vs Ioad Grey Cast Iron

50 Scratches

3. Uear Volune Vs Load Grey Cast Iron

100 Scratches

4. Uear Volume Vs Load Grey Cast Iron 500 Scratches

5. Vear Volume Vs Load Thermal spraying

1 Layer Deposit 10 Scratines.

6. : iear Volume Vs Load Thermal Sprajing

$$
2 \text { Layer Deposits } 10 \text { Scratcies }
$$

7. Wear Volume Vs Load Thermal Spraying

1 Lajer Deposit 50 Scratches

8. Wear Volume Vs Load Thermal Spraying
2 Layer Deposits
50 scratches.

171

9. Hear Volume Vs Load Thermal spraying

1 Layer Deposit 100 Scratches

10. Wear Volume Vs Load Thermal Spraying

$$
2 \text { Layer Deposits } 100 \text { Scratches }
$$

11. "iear Volume Vs Load Thermal Spraying
1 Layer Deposit
500 Scratches

12. Wear Volume Vs Load Thermal Spraying

$$
2 \text { Iayer Deposits } 500 \text { Scratches }
$$

13. - Vear Volume Vs Load powder spray welding

1 Layer Deposit 10 Scratches 
14. Wear Jollime is Load powder spray lieluing
2 Layer Dejosits
10 Scratches

15. Uear Voluke is Load Po:.der Syray Ueiding

I Layer Dejosit 50 scratches

178

16. Wear Volure Is Load powder Spray :̈elding
2 Layer Deposits
50 scratches

17. Vear Volume Vs Load Fowder Spray Vielding

1 Layer Deposit 100 Scratches

180

18. Wear Voluke Us Load powder Spray ielding

$$
2 \text { Layer Deposits } 100 \text { Scratches }
$$

19. $\because e a r$ Volume Vs Load Powder spruy $̈$ ieldine

$$
1 \text { Layer Deposit } 500 \text { Scratcies }
$$

20. Wear folume is Load powder spray Helding

$$
2 \text { Layer Deposits } 500 \text { Scratches }
$$

21. Wear Volume Vs Load Oxy-acetylene :ielding

$$
1 \text { Layer Deposit } 10 \text { Scratches. }
$$

22. Wear Voluxe Vs Load oxy-acetylene :̈elding

$$
2 \text { Layer Deposits } 10 \text { Scratcines }
$$

23. Wear Volume vs Load Oxy-acetylene iielding

$$
1 \text { Layer Deposit } 50 \text { scratches }
$$

24. Wear Volume vs Load Oxy-acetylene :̈elding

$$
\text { ¿ Layer Deposits } 50 \text { Scratches }
$$

25. Wear Voluxe is Load $0 x_{j}$-aceijlene ijeiding

$$
1 \text { Layer Deposit } 100 \text { scratches }
$$

26. Wear. vollue is Load oxy-aceiylene :̈eIding

$$
\text { ¿ Layer Dejosits } 100 \text { scratches }
$$

27. Hear Volume vs Load Oxy-aceiylene ".elding

$$
\text { - } 1 \text { Layer Deposit } 500 \text { Scratches }
$$

28. "iear Volume Vo Load Cxy-acetylene ".eldinf

$$
2 \text { Layer Deposits } 500 \text { Scratches }
$$


¿3. iear jolume is Load Tungsten Inert Gas \#elding
1 iajer Deposit
10 Scratches

30. Uea: Volune is Load Tungsten Inert Gas :ieiding

2 Lajer Jeposits 10 scratches

31. đear Vollue is Load Tungste: Inert Gas :.eidinä 1 Layer Deposit 50 Scratcines 194

32. Wear Volume Vs Load Tunesten Inert Gas $\because E I d i n g$
2 Lajer Deposits
50 Scratches

33. Hear Volume Vs Load Tunester Inert Gas :"Elding̈.
1 Layer Devosit
100 Scratches

34. Uear Voilume Vs Load Tungsten Ineri Gas Ueiding 2 Layer Deposits 100 Scratches

35. Vear Volure Vs Load Tungsten Inert Gas Welding
1 Layer Deposit
500 Scratches

36. Wear Volume Vs Load Tungsten Inert Gas Vielding

2 Layer Deposits 500 Scratches

37. Macro Hardness. I Layer Deposit

Thermal Spraying

30. Macro Hardness

2 Layer Deposits

Thermal Spräying

200

39. Macro Hardness

1 Layer Deposit

Powder Spray :elaing

201

40. Macro Harciness

2 Layer Deposits

Fo:.:der soray "̈eldinğ

201

41. Hacro iarciness

1 Layer Jeposit

oxy-acetylene ::elding

42. Macro liarúness

¿ Layer Deposits

$\because x y-a c e r y l e n e \operatorname{reldin}_{\vec{B}}$ 
43. Hacro Gardness 1 Layer Jeposit

Tunesten Inert Gas ․elding

44. ¿acro Faraness z Lajer jejosits

Tunestes: Ineri Gas .. Eläing 
SYNOPSIS 


\section{SIIOPSIS}

Eillions of vounds are lost every year in industry tinroligh Morn parts and Wastage of materiais. Ey applyine hardiaced coatings to parts or componerts most slijecied to breardown through wear, their working lifetime can be extended. The Iiterature survey on hardiacing showed that very litile work has been conducted on the hardfacing of cast iron despite the iact that this is the most widely used cast material. For this reason a orey cast iron conforming to BS 1452 : 1977 and in general use in: Agriculture, Aircrait, Automotive, Construction, Foundry, General Engineering, Nining, Nuclear, Oil, Power Stations and Ra.ilways, was selected for the investigation.

In many of the appilications for which cast iron is used wear may result in the need to replace the casting. The cost of replacing a single component which has failed can be high for several reasons. To minimise costs, the component user would wish to hold minimum or no stocks. The foundry would charge a higher cost for a one-off casting to recover set-up costs and potential scrap, cosis which would be aosorbed over longer production runs. In addition there would be a delay factor in obtaining a replacement casting wnich would lead to a down time cost. For these reasons and those related to the more efficient use of materiais, it vas considered that the methods for producing hardiaced coatinüs on cast iron, and their characteristics, was worthy or investigation.

The thesis reports the results of an investigation into the potential-assessment " 0 " spraying and welding processes for the hardiacing of grey cast iron to resist abrasive wear. Hith Erey cast iruns having a relatively low meltinä temperature it 
was necessary to ind a low melting temperature hardiacing alloy to avoid certain constituents, such as drapinte, from being burned olit of tre cast iron. The hardiacing ailoy

chosen to neet these requirenents las a richel-chromium-ooron alioy wich is comrencially available in po"der anci "as cast" rod form and offers good naraness and acrasion resistance. It was also necessary to find tre appropriate spraying and welding processes to deposit the hardfacing alloy onto the cast iron. The processes finaliy selected for consideration were:

1. Thermal spraying

2. Powder spray welding

3. Oxy-acetylene welding

4. Tungsten inert gas. weldiñ̈ (TIG)

The programme for the research was divided into two stäes:

1. The assessment of the procedures and technique for spraying and welding.

2. The assessment of the deposited hardifacing ailoy for abrasion resistance and hardness.

The thesis reports in detail the application procedures and teciniques considered to be the most suitable for spraying and welding the $N i-C r-B$ alloy onto a grey cast iron. In adcition the thesis reports the assessment of the quality of one layer and two layer deposits for abrasion resisiance and nardiness. The abrasion resistance was deternined using̈ a reciprocating diamond scratcin testing macinine. The results were ootained in the form of "wear volume" which is proportional to the width of the scratch. A statistical analysis, based on tine standard error of the mean, was carried out on the wear test results to show if any sienificant difierences occurred when each of the four processes were compared one with-another. 
The hardness of the coating car be affected if the alloy is diluted by the substrate, consequently it was necessary to measure the hardiness of the coating vitin the following tests:

1. Surface hardness

2. Niacro hardress across the interface of the hardiaced deposits, bond area and substrate.

The surface hardness results were al so tested by statistical analysis to see if any significant difierences occurred when each of the four processes were compared one with another. The above hardness tests were complemented by Electron Prode Yicroanalysis (EPMA) which measured the percentage of elements across the deposit/substrate interiace and provided an indication of the presence and degref of dilution of the harafacing alloy by the substrate.

It was also considered that an optical microscopy study of the interface sholid be conducted to provide information about the integrity of the interface.

From the overall results of the investigation it would appear that the Powder spray welding process orovided the best wear resistance closely followed by the Thermal spraying process, Oxy-acetylene welding process and the TIG velding process.

The spraying processes provided a more controlled, thinner coating with a smootiner surface finisi and low to negligible dilution of the hardfacing alloy with the cast iron substrate. The coatings required very little surface grinding to provide a smooth surface and would ve particularly suited to close tolerance engineering applications. The wear resistance and hardness of the coatings appeared to be good on both one layer and two layer deposits.

The welding processes showed a- thicker, rougher surface 
finish with a minimum of dilution and distortion on the two layer deposits. Heavy surface grinding was required to provide a smootin finish. The wear resistance and hardnesses of the coatings were not good especially on the one layer deposits, the reason for this appeared to be dilution of the hardfacing alloy with the cast iron substrate.

The welding processes would be particularly slited to where thicker coatings are required. 
INTRODUCTION 


\section{INTRODUCTION}

This investigation has the objective of establishing the practical procedures for optiuising the abrasion resistance of nardfacing coatings on Erey cast iron. Grey cast iron, conforming to BS 1452 (1), was chosen because it is the single most important cast material and a survey of the literature shoved that, although work has been conducted on steel suostrates, little research has been conducted into the hardfacing of cast irons. Cast iron has many fields of application such as: Agriculture, Aircraft, Automotive, Construction, Foundry, Mining, Nuclear, Cil, Power stations and Railways.

In many of these applications wear may be a problem which requires the replacement of castings or where possible, the reclamation of these castings. The cost of replacing a single component which has failed can be high for several reasons. To minimise costs, the component user would wish to hold rinimum or no stocks. The foundry would charge a higher cost for a oneoff casting to recover set-up costs and potential scrap, costs which would be amortized over longer procuction runs. In addition there would be a delay factor in obtaining a replacement casting which vould lead to a down time cost. For these reasons and thuse related to the more efficient use of materials, it was considered that the methods for producing hardfaced coatings on cast iron, and their characteristics, was vorthy of investigation. Grey cast irons are available in seven grades, these are: $10,12,14,17,20,23$ and 26.

The cast iron used in the investigation had a composition within the following range: (2) 
C $3.22 \%-3.32 \%$, Si $1.97 \%-2.08 \%$, Mn $1.56 \%-1.66 \%$,

P $0.104 \%-0.137 \%$, S $0.036 \%-0.038 \%$.

This composition produces a grey cast iron between grades 14 and 17 which have a tensile strength between $220 \mathrm{~N} / \mathrm{mm}^{2}$ and $260 \mathrm{~N} / \mathrm{mm}^{2}$. Grey cast iron components can be seen in use in all the major industries such as:

Automotive Engineering, Chemical Engineering, Civil Engineering, Electrical Engineering, General Engineering, Iron and Steel industry, Marine Engineering, Mining and Textiles.

With grey cast irons having a melting temperature range of $1130^{\circ} \mathrm{C}-1250^{\circ} \mathrm{C}$, it was necessary to find a low melting temperature hardfacing alloy, to avoid certain constituents, such as graphite from being burnt out of the cast iron.

The hardfacing alloy to meet the above requirements was. chosen from a list of Nickel-base alloys, which are comercially available in powder, as cast rod, tubular wire and flux coated electrode form. The alloy is a Nickel - Chromium - Boron alloy which has a relatively low melting temperature $964^{\circ} \mathrm{C}-1003^{\circ} \mathrm{C}$ (3), compared to the grey cast iron substrate.

The Ni - Cr - B alloy also offers good hardness and abrasion resistance. It is easy to apply because it contains "self fluxing" agents, (4) and it is less expensive than its alternatives, for example cobalt - base alloys (5 - 8).

After currying out a literature survey on spraying and welding processes, it was found that the processes most suitable for depositing the Ni - Cr - B hardfacing alloy would be:

Plasma arc spraying

Thernal spraying

Powder spray welding

Narual Metal arc welding (MMA) 
Tungsten Inert Gas Helding (TIG)

Oxy-acetylene welding

Metalic Inert Gas weIding ( IG)

Plasma arc spraying is the most modern of all the siaying processes and is mainly favoured for the high meltinë temperature metals and alloys. (9) It has a fast deposition rate but tine equiprent is extremely expensive.

Thermal spraying is less expensive than tine Plasma arc sprajing and can be used to apply a variety of metal and alloyed powders at fast speeds. The process can also be made portable. Powder spray welding equipment is portable and inexpensive It uses a conventional oxy-acetylene welding blowpipe with a special powder feed attachment. The deposition rate is slower than the other two processes mentioned.

Yanual metal arc welding (MMA) is a fast deposition process which uses flux coated electrodes and is mainly suited to building up heavy deposits. The process involves aelting the parent metal in the fusion zone. The equipment depending on its size can be expensive and can be made portable.

Tungsten inert gas welding (TIG) is an alternative to the likA process, with the advantage that the arc is not as forceful, therefore less severe compared with the MA process. An "as cast" rod is deposited in an argon gas sinield to prevent oxidation. The equipment is expensive but the process can be used for other welding agjications. Tnt equipment can also be made portable.

Oxy-acetylene velding deposits an "as cast" rod, like the TIG process. Trie process is sumetimes described as bräe welding (10), rather than fusion welding, because the parerit metal does not become molten. The equipment is inexpensive and can gener- 
ally be found in most welding workshops. It is portable and can easily be adapted to carry olit spraying, welding, preheating and flame cutting.

letallic inert gas welding ( $\because I G)$ deposits a continuous tubular wire (7), with the alloy forming the core, which is shrouded in a gas sinield. The deposition rate is very fast and involves melting the parent metal in the fusion zone. The equipment is expensive but by changing the wire and gas shield, it can be adapted to other welding applications. The equipment can also be made portable.

A major problem that occurs when depositing hardfacing alloys by spraying or welding is dilution, that is, of the hardfacing alloy by the substrate material. The dilution problem is greater with the arc processes because they melt the parent metal at the fusion zone. There are many factors that affect dilution. Evidently single layers of alloy will have a greater dilution than will multi-layers. The technique used to deposit the alloy can also affect the dilution for example, the greater the amount of weaving the greater the dilution (II). Dilution with the substrate material can cause a significant decrease in the hardness and wear resistance of the deposited coating.

The spraying and welding processes decided upon to deposit the $\mathrm{Ni}-\mathrm{Cr}-\mathrm{B}$ alloy in the investiogation were:

Thermal spraying

Powder særay welding

Oxy-acetylene welding

Tungsten inert gas welding (TIG)

They were all selected for the following reasons:

1. The processes can be normally found in most welding workshops. 
2. The equipment is not too expensive.

3. Dilution of the hardfacing alloy by the substrate can be kept to a minimum.

4. All the processes are or can be made portable.

Different application procedures and techniques, involving different levels of operator skills, are required for the deposition of hardfacing alloys by each of the above processes.

To take into account both the requirements for application procedures and the assessment of the wear characteristics of the coatings the experimental programe was divided into two sections.

1. The application procedures and techniques of the spraying and welding processes.

2. The assessment of the hardness. and wear resistance (abrasion) of the $\mathrm{Ni}$ - Cr - B hardfacing alloy after deposition. 
CHAPTER 1

LITERATURE SURVEY 


\section{CHAPTER 1}

\section{LITERATURE SURVEY}

\subsection{Hardfacing}

fiardfacing is a process in which a layer of alloyed metal is deposited onto a softer and cheaper material, or substrate, to improve the wear resistance of the base metal (12).

Hardfacing extends the working lifetime of parts or components most slibjected to wear and breakdown and hard faced surfaces can last up to five times longer (13) than unprotected surfaces, depending on the alloy lised.

The use of surfacing materials to improve the wear resistance of parts against abrasion, impact and corrosion dates back to about 1906 (14).

\subsubsection{Reasons for Hardfacing}

The main reasons for hardfacing can be considered under three headings:

1. Economics

2. Reclamation

3. Coating new parts

\section{Econornics}

In most circumstances, economic considerations dominate the justification for hardfacing. Ellis and Garrett (15) expressed surprise therefore, that economic criteria appeared to be the least well documented and most confusing aspect of hardfacing technology.

In 1966 a Government inquiry under Professor Jost (16) estimated that industry was losing more than $£ 500$ million per annum in worn parts because of its failure to appreciate 
the problem and now it could be overcome. Twenty years later the estimates now exceed $₫ 2$ billion (17). The total world costs. for maintenance are enormous, to say nothing of the wastage of materials and energy and the depletion of metal and fossil fuel reserves, some of which will, by the year 2000 , be in short supply $(18,19)$.

In view of the need for energy and materials conservation it seems more than likely that in the future composite materials, including those produced by welding, will be utilisedincreasingly to save on expensive and scarce metals (20).

\section{Reclamation}

The most comnon use of hardfacing is to build up worn areas on used components to improve their service life. This will enable production to be maintained for longer periods without shut down and, additionally, will improve the rate of production and the quality of the product (10).

Often the time taken to obtain a spare part is extended, so replacements must be ordered far in advance. If the Iife of the rachine corponent is indeterminate, the spare may be in store for many years. Not only is working capital tied up, the related interest inay be high and aggravated by the cost of space, stores handling, insurance etc. . A relatively small investment in surfacing equipment may make possible the repair of a vast array of production macinines at snort notice (17). According to Shailes (2l) it is possible to show in some cases a saving of as ruch as $50 \%$ for a part that has had its surface refurbished when compared to buying or thanufacturing a new part.

\section{Coating Neiv Parts}

Increasingly couponents are being harafaced before being 
put into service. Consequently, hardfacing may be considered as a production process, from the design stage, ratiner than merely a reclamation process ( $2 \bar{c}$ ). Many mechanical parts are made from costly sophisticated base metals, for example aluminium bronze gear box selector forks(23, 24) al though only certain areas require specialised properties. Ey applying coatings, such as hardfacing alloys of superior wear resistance, to these areas, many such parts could be produced from inexpensive retals at a fraction of the cost (25) and without the need for heat treatment.

Design engineers must be educated in the need for materials conservation and the potential for improving component life by specifying techniques such as hardfacing.

\subsection{Nickel - Base Alloys}

Alloys containing about $75 \%$ nickel and $20 \%$ chromium, together with a few per cent of boron, have good corrosion and wear resistance (26). The hardness values of the deposited alloys generally range from $350 \mathrm{HV}-790 \mathrm{HV}$ (27). They have extremely good hot hardness up to about $650^{\circ} \mathrm{C}$, after which the hardness falls off rapidly due to their low melting temperature which ranges from $964^{\circ} \mathrm{C}-1152^{\circ} \mathrm{C}$ (3).

Since their development the Nickel-base alloys have been manufactured in powder, "as cast" rod, tubular wire and flux coated electrode form. The powder, "as cast" rod and tubular wire can be bought commercially but the coated electrodes normally have to be made to order and bought in large quantities for them to be economical to manufacture.

Recently in Britair the alloys have been manufactured by continuous casting $(5,6)$ producing a close tolerance hardfacing rod in any length. This opens up for the first time 
the use of the materials in mechanised welding processes. Nickel-base alloys are mostly suited to powder and"as cast" rod, because they are the "self fluxing" type (4). The fluxing agents winch are added to the alloy are boron and silicon. These fluxing agents have the ability to dissolve oxides of iron, nickel or chromium and form a hard, smooth protective film wich prevents atmospheric oxidation.

All the Nickel-base "self fluxing" alloys are very low in ductility and they also have high thermal expansion coefficients. Consequently, in base materials having a low thermal expansion coefficient there is always a chance of cracking. During cooling, if the coating shrinks appreciably more or faster than the base material, high stresses develop and the ductility and elasticity of the coatings may not be enough to prevent cracking (28).

\subsubsection{Applications of the Nickel-base Alloys}

Because the alloys exhibit: good metal to metal wear; good low stress scratch abrasion; abrasion and corrosion resistance; and a retention of hardness at elevated temperatures (29); they are used for numerous applications. Typical applications for nickel-base hardracing alloys are: (30)

Agriculture:- Bean and cane knives, drill shoes and scraper knives, plough shares and potato diggers. Automotive and Aircraft:- Arrester hooks, jiEs and fixtures, cams, bearing surfaces, exhaust valves (diesel), rocker arms, water pump shafts. Construction:- Cable drums, dredger pinion shafts, tractor sprockets.

Foundry:- Conveyor parts, mill guides, sand dredgers, shot blast equipment. 
Ninina:- Coal washers, pump impellors and spider rings. Railways:- Flange tracks, shackle pins, dall joints,

track frogs and wagon couplers.

Also, according to Allnat and Bell ( 8 ), extensive experience has shown that a number of traditional nickel-base alloys offer good surface protection for engineering components in Nuclear ervironutents.

1.2.2 Nickel - Chromium - Boron Hardfacing Alloys

The Ni - Cr - B alloy to be deposited in the investiöation was chosen from the list of nickel-base alloys which are commercially availabie. The alloy was chosen because it offers good abrasion resistance and its low melting temperature, relative to the other hardfacing alloys available, was an essential requirement with grey cast iron being used as the substrate.

In 1937 Cole and Edmonds (31) were granted a patent for a nickel - chromilu - boron hardfacing alloy narned COLMONOY* after their names (COL from CULE, MON from EDNONDS and OY from ALLOY). They found that Ni - Cr alloys could be hardened by tine introduction of boron. Subsequentiy a whole range of $\mathrm{Ni}$ - $\mathrm{Cr}$ - B alloys has been developed to meet the demand for a variety of mechanical properties.

The typical composition of the alloy chosen is (3): Chromiun - 15\%, Boron - 3\%, silicon - 4\% - 5\%, Iron $4 \%-5 \%$, Nicirel - Balance.

The nickel provides corrosion resistance whereas chromium inproves high temperature oxidation resistance and increases

* COllionor is the registered tradenark of wall ColnoNoY CORPORATION 
strength and wear resistance. Boron is present mainly in the form of nicrel or chromium boride particles. These are dispersed througholit the Ni - Cr alloy matrix and are responsible for much of the hardness and abrasion resistance. Boron, together with silicon, lowers the melting point of the eutectic/ solid solution matrix and tinis reduces the application temperature requirec (32). The melting temperature of the alloy is between $964^{\circ} \mathrm{C}-1003^{\circ} \mathrm{C}$ (3).

The hardness of the deposited alloy is usually between $710 \mathrm{HV}-790 \mathrm{HV}$ (27) but hardness of up to $4600 \mathrm{HV}$ have been recorded $(33,34)$. However, it should be emphasized that hardness alone is known to be a poor guide to abrasion life (35), wich derives principally from the structure. ii. - Cr - B alloys exhibit a complex structure containing chromium carbide, and chromium boride particles, which exnibit the characteristic of extremely high hardness. The alloy has a long freezing range, some $100^{\circ} \mathrm{C}$ between liquidus and solidus temperatures. This permits the alloy to retain its shape and rigidity during̈ fusing, reducing the chance of sagging or running (34). The low melting of the nickel eutectic matrix limits the use of the alloy to below $950^{\circ} \mathrm{C}(29)$.

\subsubsection{Expansion and Contraction of Ni - Cr - B Alloys}

$\mathrm{Ni}$ - Cr - B alloys have a high coefficient of expansion and have a tendency to crack during applicatiun. On surfaces which are flat, cylindrical or curved, shear and tensile stresses can be developed as the coating is applied.

Slow cooling of the alloys after deposition is essential as they have a tendency to crack when cooled too rapidly. Cooling can be carried out in a furnace or by covering the component with sand or insulating powder. 


\subsection{Grey Cast iron BS 1452: 1977 (1)}

Cast iron is an alloy uf severul elements but accoriing to BS 1452 the composition of the iron sholid be left to the discretion of the manufacturer.

In grey cast iron the majority of the carion present is in the free state, as graphite and this graphite is normally in flake form. The melting temperature of grey cast iron is in the range of $1130^{\circ} \mathrm{C}-1250^{\circ} \mathrm{C}$.

There are seven grades of Erey iron castings:

$10,12,14,17,20,23$ and 26 vihich correspond to the following tensile strengths:

$150,180,220,260,300,350$ and $400 \mathrm{~N} / \mathrm{mm}^{2}$.

\subsubsection{Expansion and Contraction of Grey Cast Iron}

The fraction of its length which a metal will expand when heated through one degree rise in temperature is termed its coefficient of linear expansion (this also applies to contraction when the metal is cooled). The coefficient of linear expansion of cast iron is 0.000010 per degree Celcius $(36)$.

The expansion and contraction of cast iron is of great importance to the welding operator. This is because of the large forces or stresses that can be generated during welding. The low ductility of grey cast irons and their inability to relieve plastically can cause the castinfs to fracture.

During some welding processes, such as $0 x y$-dicet ${ }_{j} l e n e$ welding, the workpiece normally absorbs a considerable amount of heat and this can be advantageous since it eliminates the steep thermal gradients that create the internal stresses (13). 


\subsubsection{Applications of Grey Cast Iron}

A grey cast iron, with a tensile strength between $220 \mathrm{~N} / \mathrm{mm}^{2}$ and $260 \mathrm{~N} / \mathrm{mm}^{2}$, was used for the investigatior: From the literature survey it would appear that this grey cast iron is the most commony used by such industries. as the following (37):

Automotive, Chemical Engineering, Civil Engineering, Electrical Engineering, General Engineering, Iron and Steel Industry, Marine Engineering, Mining and Textiles. Typical components produced in grey cast iron include: Bottle moulds, chain and gear wheëls, crane drums, crankshafts, fly wheels, general pumps and machine tools. Components of grey cast iron can also be found in plant such as:

Compressors; diesel engines, earthmoving plant, general engineering machines, quarry machinery, tractors and transmissions.

In view of its wide usage, grey cast iron is likely to encounter a variety of wear mechanisms. Provided below are three examples of grey cast iron components subjected to abrasive conditions which have been coated with a Ni - Cr - B hardfacing alloy.

1. Reclaiming the drive rolls on a barrel painting machine. The cost of the reclaination was a quarter of the price of new rolls and increased the service life from two months to eighteen months. This resulted in a cost saving of over $90 \%$ (32).

2. Worn cable grooves in crane druins were rebuilt and then remacinined to their original profile, with great cost savings. 
3. Class bottle moulds were clad to extend their service Iife with consequent economic advantages (24).

\subsubsection{Preparation of Grey Cast Iron prior to Hardiacing}

The sliccess of any nardfacing operation depends on the preparation of the substrate suriace. If the surface is not prepared correctly then the coating will not bond to the substrate (33). Several methods can be lised to prepare the surface and the most common methods are:

1. Pre-cleaning (38) must be carried out if the surfaces have oil, grease or other foreign matter on them. It is good practice to use a solvent wash or degreasing filuid and then heat to approximately $290^{\circ} \mathrm{C}$ to drive out any oil from the pores of the cast iron.

2. Undercutting ( 38 ) is carried out on cylindrical components by machining and the depth of the undercut is usually determined by the service conditions. Shoulders at the ends of the undercut sections should be opened at about a $40^{\circ}-50^{\circ}$ angle, with respect to the axis of the component, see FIG. I.I

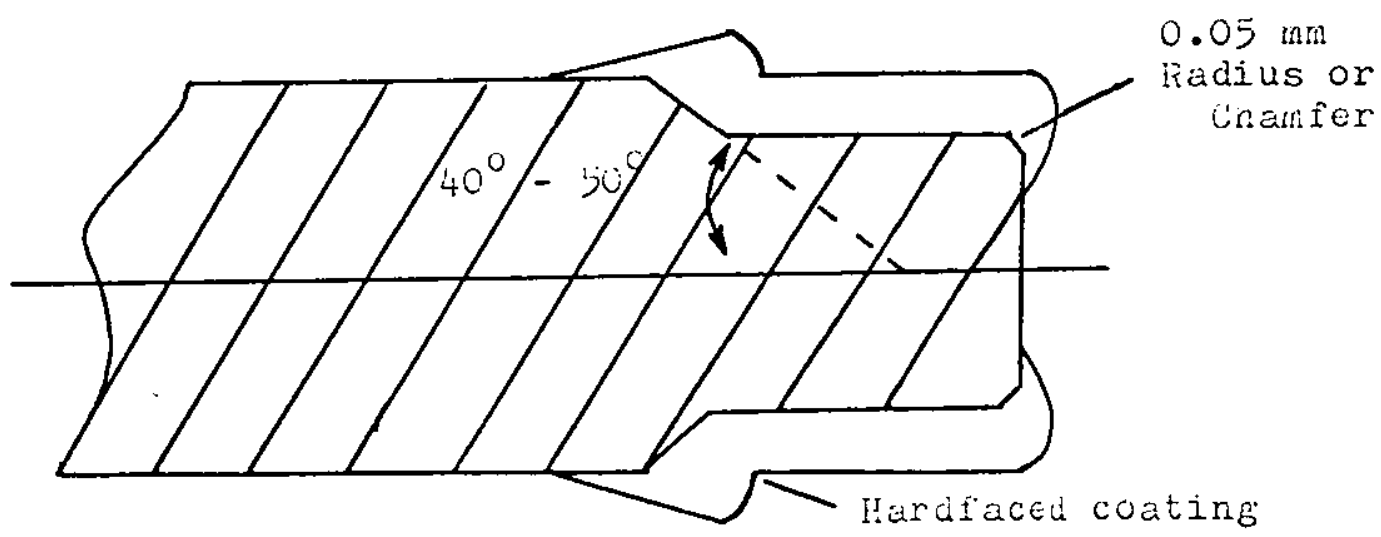

FIG. 1.1 UNDERCUTIING 
3. Rough threading $(37,38)$ of some cylindrical comporents cari be accomplished by using a $60^{\circ}-70^{\circ}$ pointed tool with a negative back rake. A full deptin thread should be cut in a single pass, see FIG. 1.2

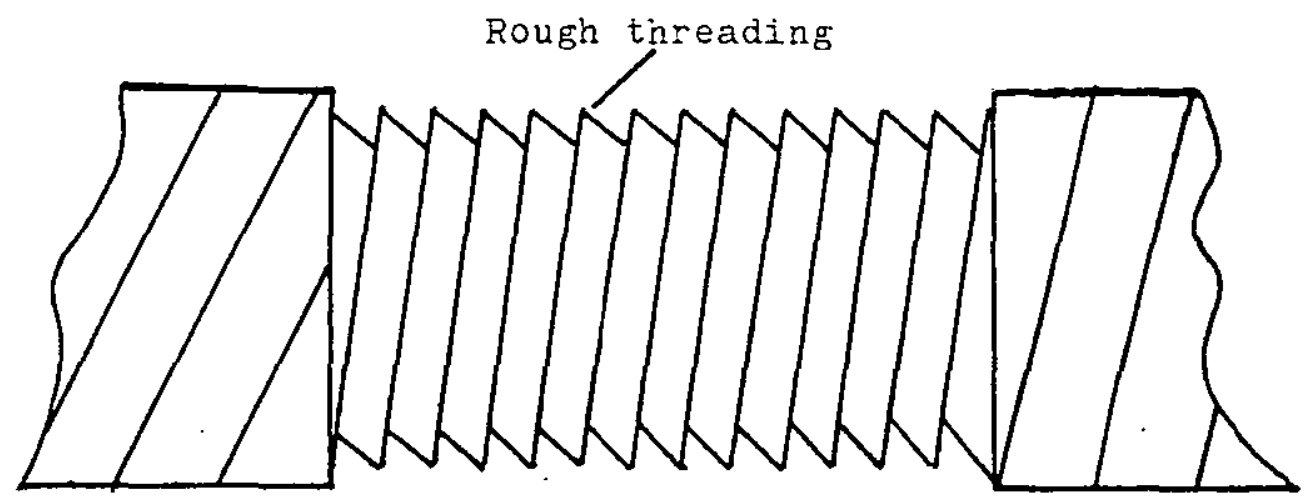

FIG. 1.2 ROUGH THREADING

4. Grit blasting $(38-40)$ is generally considered to be the most satisfactory and versatile method, al though this is contested by Ballard (41). The amount that the surface needs roughening by the grit depends on the type and thickness of the coating being deposited.

\subsubsection{Preheating of Grey Cast Iron prior to Hardfacing}

Preheating may be necessary for the following reasons:

1. To prevent cracking;

2. To reduce residual stresses;

3. To reduce distortion

The entire part to be hardfaced may be preneated or it may be preheated locally if only part of the surface is to be coated. :hen local oreheatine is apylied to grey cast iron extreme care is required in the initial stages to avoid 
cracking die to thermal snock (24).

The preheating temperature for grey cast iron is between $400^{\circ} \mathrm{C}-500^{\circ} \mathrm{C}$ (except for Thermal sprajing process, see 2.1.1) and correct control of the terperature is important ( $4 \dot{1})$. Furnace preheating is the best metrod but if a furnace is not available then either a propane burner or oxy-acetylene torch may be used anc the temperature measured using a surface contact pyrometer or heat sensitive crayons.

\subsection{Spraying and Velding Processes}

There is a large number of spraying and welding processes. available for depositing hardfacing alloys. From the literature survey it was found that the following processes appear to be tine most suitable for depositine the nickel-base alloys:

1. Piasma arc spraying

z. Thermal spraying

3. Powder spray welding:

4. Marual metal arc welding (MMA)

5. Tunssten inert gas welding (TIG)

6. oxy-acetylene welding

7. Metallic inert gas welding (MIG)

\section{Plasma arc spraying}

Plasma arc spraying is the most modern of all the spraying processes but the equipment cost is very expensive and, according to Matting (9), the process is mainly favoured when high temperature metals, carbides, oxides or cermets are to be sprayed. Up to $4.5 \mathrm{~kg} / \mathrm{hr}$ of hardfacing powder can be deposited using a $40 \mathrm{KW}$ Plasma arc spraying head (43).

\section{Thermal spraying}

Thermal spraying is an alternative to the Plasma arc sprayinğ, it is less expensive and can apply an infinite 
variety of metals, alloys, ceranics and cermets at speeds and costs which are econonicaliy feasiole (44). The process can be rade portable.

\section{Powder spray welding}

Powder spray welding is an extension to the oxy-acetylene welding process. It involves using the same blowpipe but with the addition of a special powder feed attachment. The equipment is portable and inexpensive. When not used for spraying the equipment can be quickly changed over for the conventional gas welding process.

\section{Manual metal arc (MA) welding}

Manual metal arc (MMA) welding is a fast deposition process using flux coated electrodes. It is a popular hardfacing method and is well suited to building up heavy deposits on large areas (26). The process involves melting the parent metal in the fusion zone. The fusion zone then becomes mixed or diluted in with the hardfacing alloy. If cast iron is used as the substrate it is probable that essential constituents, such as graphite, would be burnt out. The equipment is inexpensive and is usually portable.

\section{Tungsten inert gas (TIG) welding}

Tungsten inert gas (TIG) welding is an alternative to the MMA process with the advantage that the arc is much softer and therefore does not melt the surface area quite so severely. A tungsten electrode initiates the arc which is shrouded by an argon gas shield to reduce oxidation. An as cast rod is used as the depositing alloy. The deposition rate is slower than the MMA process and equipment costs are expensive but the process can be used for other welding operations, mainly for aluminium and its alloys. The process can 
be made portabie.

Oxy-acetylene welding

Oxy-acetylene welding can Eenerally be found in all welding workshops. The process deposits an as cast rod, like TIG, and is sometimes described as orazing (10) ratier tinan welding because the parent metal does not become molten. The equipment is portable, inexpensive and versatile because it can be used for spraying, welding, preheating or flame cutting operations at low costs, virtualiy anjwhere.

Metallic inert gas (MIG) welding

Metalic inert gas (NIG) welding uses a continuous tubular wire (7) with the alloyed powder forming the core which is shrouded in a gas shield. Like MA, dilution caused through melting the parent material is high. The deposition rate is fast and the process is mainly used for building up heavy deposits over large areas. The equipment is expensive but can be easily converted for other applications just by changing tine wire and gas shield. The equipment is also portable. The spraying and welding processes chosen to deposit the $\mathrm{Ni}-\mathrm{Cr}-\mathrm{B}$ alloy in the investigation are:

Thermal spraying, Powder spray weldiñ̈, Oxy-acetylene welding and TIG welding.

The processes were selected from the seven processes for the following reasons:

1. The processes can be generally found in most welding workshops.

2. The equipment costs are not too expensive, compared to some of their alternatives.

3. Dilution with the parent metal can be kept to a minimum. 
4. All the processes are or can be made portable.

The processes selected for the investication are discussed in greater detail in LHAPTER 2 .

\subsection{Dillition}

Dilution is defined by Davies (II) in tine following way: Wher two metals are fusion welded together, the rinal composition consists of an admixture of parent plate and welding wire. The parent plate has melted in with the filler and has diluted it".

Dilution by the substrate durinö nardfacing appears to be a greater proviem with arc processes than it does with the Oxy-acetylene or Powder spraying processes. A comparison of dillition effects is provided in Table 1 (2l). It can be seen that in the case of tine open arc process, dilution could cause a significant decrease in the hardness of the coating.

\section{Table 1}

\begin{tabular}{|l|c|c|}
\hline \multicolumn{1}{|c|}{ Process } & Deposit tnickness. & $\begin{array}{c}\text { Dilution } \\
\text { Single layer }\end{array}$ \\
\hline TIG & $1.6 \mathrm{~mm}-5.0 \mathrm{~mm}$ & $5 \%-10 \%$ \\
Thermal spraying & $0.5 \mathrm{~mm}-2.4 \mathrm{~mm}$ & NIL \\
Powder spray welding & $0.5 \mathrm{~mm}-3.0 \mathrm{~mm}$ & Up to $5 \%$ \\
Oxy-acetylene & $1.6 \mathrm{~mm}-5.0 \mathrm{~mm}$ & Up to $5 \%$ \\
Open arc & $2.5 \mathrm{~mm}$ & Up to 30\% \\
\hline
\end{tabular}

Deposit Thicknesses and Dilution (21)

To minimise the dilution in arc processes the current must be kept as low as possible, consistent with the production of a sound bead of alloy (32) and this must be combined with a two layer deposit (45). 
The wide range of dilution exnibited by tine velding processes does not imjly lacs of control. However, it reflects. the wide variations that can occur depending on the weldine conditions i.e. current, travel speed and the welding technique. One technique includes a degree of overlapping of acijacent weld beads. By overlapping, the alloy is being mixed with the adjacent alloyed bead so less alloy is actually being diluted with the substrate, see FIG. 1.3 .

Mixing of a proportion of parent metal with deposited alloy can affect the composition and the microstructure, and hence the wear resistance (46).

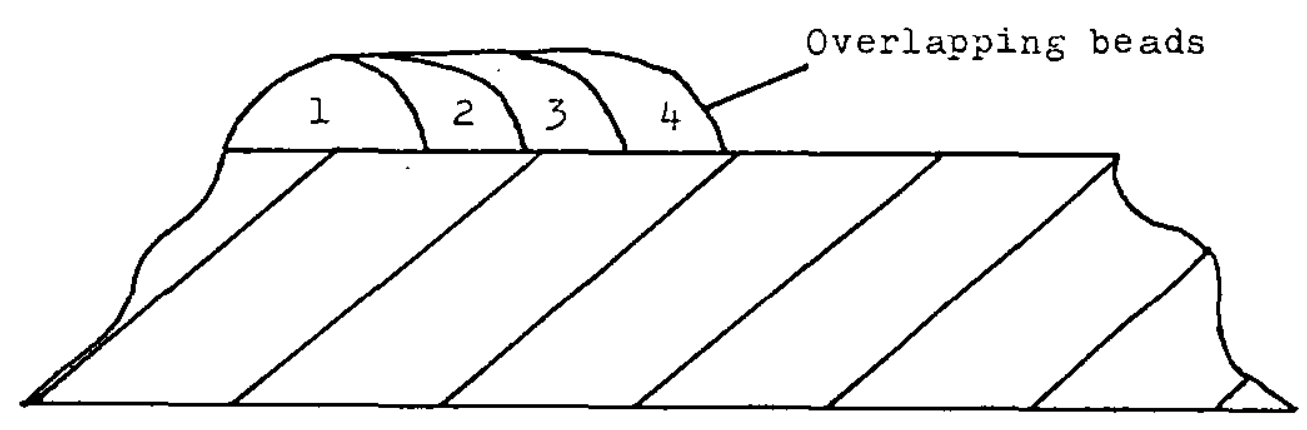

FIG. 1.3 OVERLAPPING TECHNIQUE

\subsection{Wear}

Wear, in the general sense, has been known to uan since his earliest days, however, only since the mechanical age has it been specially studied witn a view to its prevention or miniaization. It was not until the be ginneng of tne Pwentieth Century tinat any considerable attention was paid to the improvement of surfaces for tine prevention oi wear. Faced vith, for exattples, nigher working speeds of machinery, artificial abrasives, tine rise of the interral conbustion engine and. the replactent of the old self-nardened steeis oy hagn speed 
cutting-tool steels, Engineers folind the need for a greater understanding of sliffaces and their suscejtibility to wear (47). Wear may be defined as the deterioration or a surface during use (48) and it occurs in a wide variety of operations. No general rule holds for all manifestations of wear. It is affected by a variety of conditions such as: the type of lubricant; temperature; hardness; surface finish; presence of foreign materials and the chemical nature of the environment (49). In many wear situations a combination of these variables makes it very difficult to determine the precise type of wear which has occurred.

Wear (17, 50, 51) encountered in industrial situations can be broken down into various categories and the frequency with which the various main types of wear occur is estimated to be as follows:

Abrasion 50\%; Adhesion 15\%; Erosion 8\%; Fretting 8\%; Chemical 5\%; Niscellaneous $14 \%$.

\subsubsection{Abrasive Wear}

Abrasive wear is usually caused by particles, often nonmetallic, present in one or both of the mating materials or in the environment in which they operate. These particles score the metal and tear away elongated chips or slivers from the surface $(18,50)$. The rate of abrasion is governed largely by the harciness of the surface, its strength and possibly its toughness (47). Because hardness is a majur factor this explains why materials hardened on the surface are used wherever possible for wearing surfaces. 1.6.2 Classification of Abrasive Mear

Abrasive wear can be classified according to one of three causes (42): gouging; grinding; or scratching, al tholigh 
there may be some overlap between them.

Gouging abrasion involves nigh stresses on a large scale, usually associated with impact in service, tris leads to a plastic flow in tine metal base (52) and usually occurs when the abrading agent is anchored or well supported in some way. If the surface is too soft for the application, prominent grooves are cut into the wearing surface under the gouging action of the abrasive material.

Grinding abrasiun results from extremely high compressive or shear stresses which occur when small hard particles are crushed or nipped between metallic faces. The broken abrasive grains are sharp and score the metal.

Scratching abrasion is often known as erosion and the low stresses produced are the result of sharp particles travelling at speed $(4 \hat{C})$. The contact between the surfaces is. slight and the abrasive material is composed of extremely sharp particles of high abrasive power, not usually broken up by the stresses involved.

\subsubsection{Abrasive Wear of $\mathrm{Ni}-\mathrm{Cr}-\mathrm{B}$ Hardfacing Alloys}

Relatively little information is available on the abrasive wear of $\mathrm{Ni}-\mathrm{Cr}-\mathrm{B}$ alloys. However, in the literature it is asslimed by researchers that these alloys have an excellent wear resistance $(7,29,53)$.

\subsection{Safety}

\subsubsection{Funie Extraction and Ventilation}

Welding processes produce fumes and the degree of hazard to the welding operator depends on the composition of the fumes and gases and their concentration in the air inhaled. Fumes may contain ozone and oxides of nitrogen along with other compounds. To avoid the toxic and roxious effects of 
these fumes, suitaole ventilation or extraction systems are required when carrying out spraying and welding operations.

\subsubsection{Respiratory Hazards}

Materials in finely divided form may be danaging to the respiratory system to a varying degree. Grit blasting and spraying (54) both produce dusts which snould be considered as hazardous, especially when grit blasting or spraying toxic materials.

Chromium alloys are extremely hazardous. When spraying or welding these metals complete respiratory protection must be used by the operator.

\subsubsection{Equipment Safety}

All oxy-acetylene equipment mist conform to British Standards and a booklet by the Health and safety at work Executive Committee (55) refers to these British Standards and provides general guidance on the safe use of compressed gases for welding, heating and deposition of metals.

For the construction and use of electric arc welding equipment BS 638 (56) must be followed. A booklet by the Department of Employment and Productivity (57) on Electric arc welding gives general guidance on safety, construction and use of electric arc welding equipment in industrial and other employments.

1.7.4 Personal protection

Welding processes have a hish heat output and produce infra red and uitra violet light. Exposure to these hazards requires the following protection for the welding operator:

1. Eye protection regulations came into operation on the loth April 1975 (58) and must be followed. For arc welding and gas welding yrocesses, sinields 
and goggles must be lised that conforr to BS 1542 and the filters or lens shall conform to BS 679 .

2. Protective clothing for welding operators should conform to BS 2653 and requires clothing such as: (a) Leather aprons to sinield the body from heat given off from the welding process and to prevent burns as a result of small glooules or metal falling onto tinigins and legs.

(b) Leather gloves are necessary to shield hands and forearms from heat, sparks and radiation from the electric arc.

(c) Boots and leggings to protect the feet and legs in the same way as the hands and forearms.

\subsection{Summary of Literature Survey}

\subsubsection{Grey Cast Iron Substrate}

A grey cast iron, with a tensile strength of between $220 \mathrm{~N} / \mathrm{mm}^{2}$ and $260 \mathrm{~N} / \mathrm{mm}^{2}$ was chosen as the substrate for the investigation. From the literature survey it wolld appear that this type of grey cast iron is in common use by such industries as the following:

Automotive, Chemical Engineering, Civil Engineering,

Electrical Engineering, General Engineering, Iron and Steel Industry, Narine Engineering, Nining and Textiles. With the grey cast iron having a melting terperature range of $1130^{\circ} \mathrm{C}-1250^{\circ} \mathrm{C}$ a hardfacing alloy with a lower melting teimprature had to be selected to avoid certain constituents such as, graphite from being burnt out of the cast iron. However, the alloy must still provide good hardness and abrasion resistance. 


\section{8 .2 il - Cr - B Hardfacing Alloy}

A Ni - Cr - B alloy with a typical composition of $\mathrm{Cr}-15 \%, \mathrm{~B}-3 \%, \mathrm{Si}-4 \%-5 \%, \mathrm{Fe}-4 \%-5 \%, \mathrm{Ni}-\mathrm{Bal}$ ance was chosen from the list of commercially available nickelbase alloys to meet the above objectives. The Ni - Cr - B alloy has a low meltinf temperature $964^{\circ} \mathrm{C}-1003^{\circ} \mathrm{C}$; a hardness range of $710 \mathrm{HV}-790 \mathrm{HV}$ and it also provides good abrasion resistance. The alloy is available in powder, "as cast" rod, tubular wire and flux coated electrode form. The alloy is the "self fluxing" type and provides ease of application and the ability to dissolve oxides of iron, nickel or chromium and form a hard smooth protective film which prevents atmospheric oxidation.

\subsubsection{Spraying and Welding Processes}

The spraying and weloing processes were chosen from a list of seven processes that appeared from the literature survey to be the most suitable for depositing tine $\mathrm{Hi}-\mathrm{Cr}-\mathrm{B}$ alloy, these viere:

Thermal soraying; Powder spray welding; Oxy-acetylene welding; TIG welding.

The processes were selected for the following reasons:

1. Dilution with the slibstrate is a problem when hardfacing because it can reduce the hardness and wear resistance of the deposit, so the processes had to produce minimal dilution.

2. The processes can generaliy be found in nost velding worksiops.

3. The equipment costs are minimal compared to some of their alternatives. 
4. All tine processes can be made portable, so deposition of the alloy can de carried out virtually anywinere.

5. Various levels of welding operator skills are required to use the processes.

\section{8 .4 Safety}

When setting up and using the equipment for spraying or welding, good safety practice is essential and British Standards must be followed, especially in tine following areas:

Extraction and ventilation; Respiratory protection;

Personal protection; and Construction of equipment. 
CHAPTER 2

SPRAYING AND WELDING

PROCESSES 


\section{CHAPTER 2}

\section{SPRAYING AID WELDING PROCESSES}

\subsection{Thermal Soraying}

Thermal sprajing (59) is the term developed from the original process known as metal spraying or metallizing. However, because non metallic niaterials are also sprayed, the process of metal spraying is more aptIy described as Thermal spraying. The spraying process was invented in 1910 by $\operatorname{Dr}$. Schoop $(30,60)$ in Switzerland. Fis first work was carried out by spraying heated metal powder, but he later developed an automatic wire feed pistol or gun for metal spraying.

Abolit 1945 a process to spray hardfacing alloys in powder form onto a surface to provide a deposit, which colld be subsequently heated and welded, was discovered and the spray weld process was born (29). In the last twenty five years techniques involvine the use of Plasma arc (59.) and Electron beam (61) for spraying coatings have been develoged, but the equipment is expensive.

The most economic process lised is Thermal spraying (powder process) using acetylene as the fuel gas. As two operations are lised in this process, spraying followed by fusing, the process is sometimes described as the spray Fused process $(26)$.

\subsubsection{Operating Technique}

The powdered alloy is fed by a trigger mechanism, see FIG. 2.I (62), from a hopper or canister winich is attached. to the gun and passes through the heating zone of the flame. 


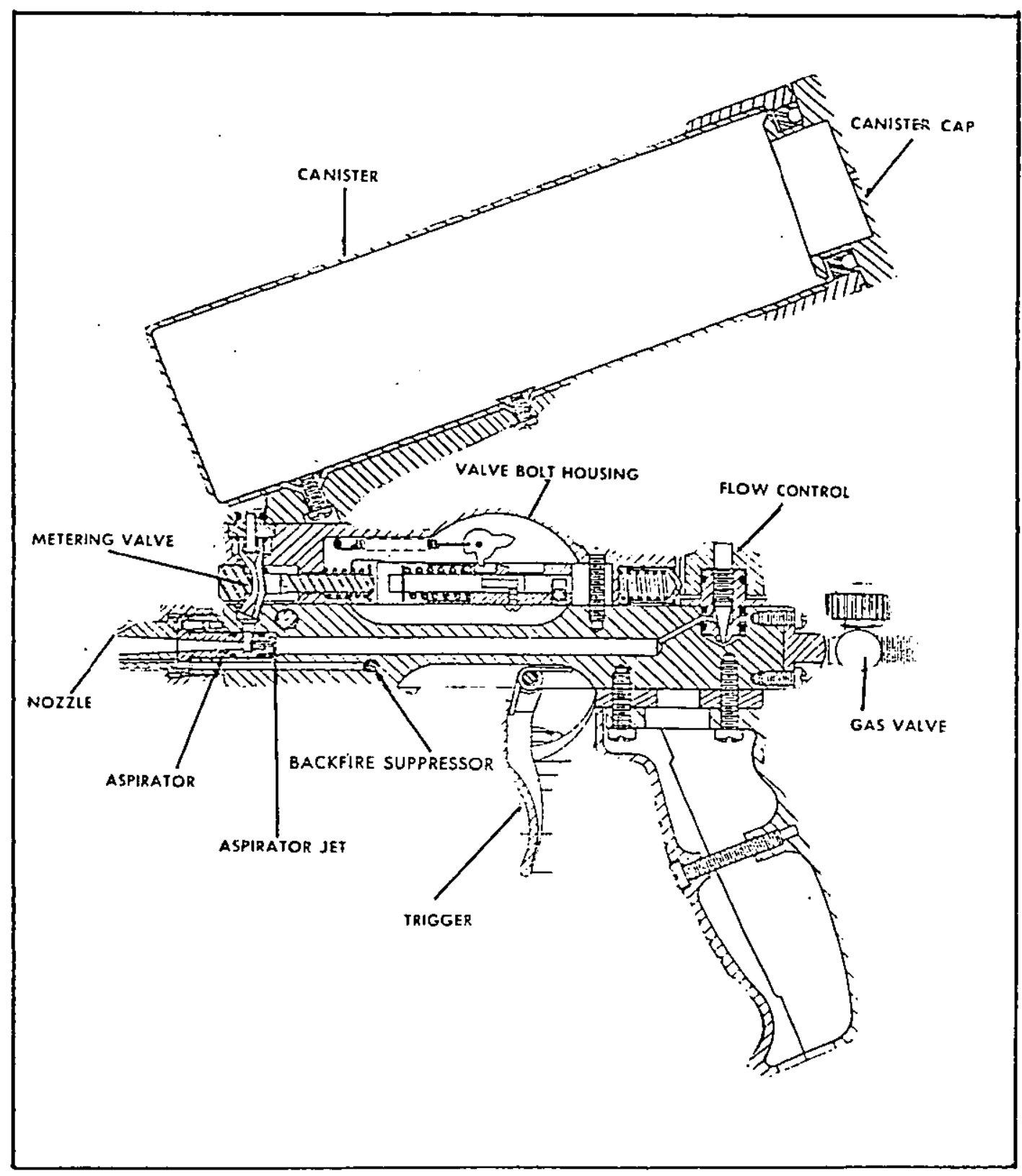

EIG 2.1 Metco Type 2P Thermospray Gun(62) 
The powcier melts to produce fine particles which are then projected by the flame, the ener $\mathrm{Ey}$ is provided by tine expanding fuel gas mixtures ( 8 ), onto the prepared substrate.

The chart figures supplied by the spray gun manufacturers should be followed as closely as possible for the gas flow, powder feed and nozzle distances, see Table 2 (62). After preheating the substrate to $93^{\circ} \mathrm{C}$ (38) the flow control valve is set to the required number of clicks, see Table 2. The powder is then sprayed onto the substrate and, depending on the substrate being stationary or rotated in a Iathe, the travel speeds provided in Table 3 should be used. During application of the powder the substrate temperature should be kept below $260^{\circ} \mathrm{C}$ otherwise the substrate may overheat and coating stresses are increased. This may cause cracking or separation of the coating as shown in Plate 2.I.

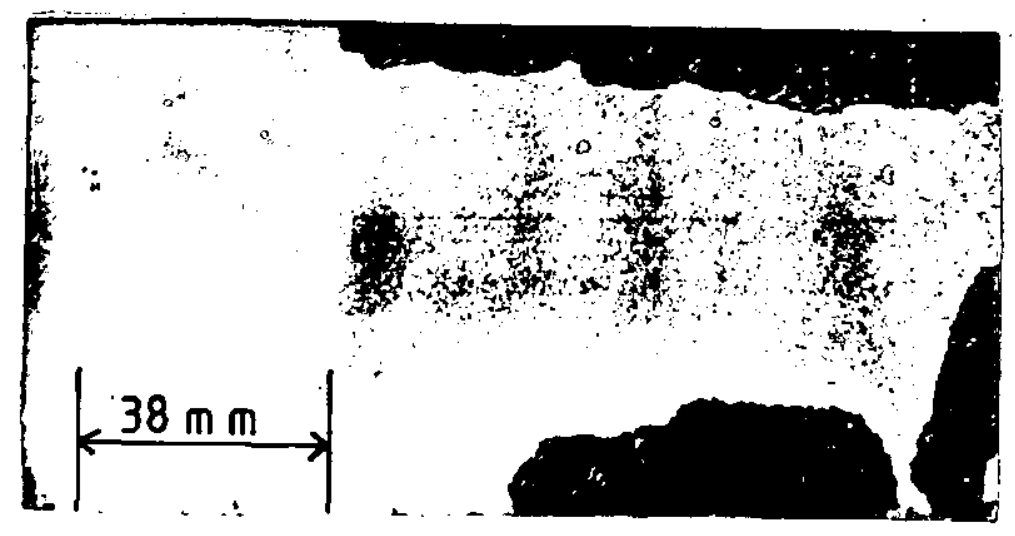

PLATE 2.1 Separation of Deposited Coating 
Table 2

\begin{tabular}{|c|c|c|c|c|c|c|c|c|c|c|c|c|c|c|c|c|c|}
\hline \multirow[b]{2}{*}{ 总 } & \multirow[b]{2}{*}{ 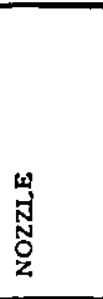 } & \multirow{2}{*}{ 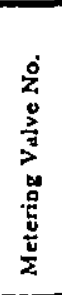 } & \multirow{2}{*}{ 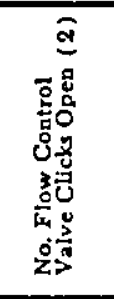 } & \multicolumn{3}{|c|}{ 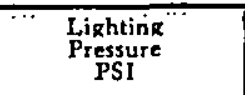 } & \multicolumn{3}{|c|}{$\begin{array}{c}\text { Flow } \\
\text { Meterer } \\
\text { Readings }\end{array}$} & \multicolumn{4}{|c|}{$\begin{array}{l}\text { Consumption } \\
\text { Per Hour (3) }\end{array}$} & \multirow{2}{*}{ 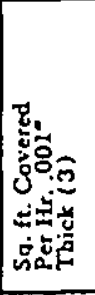 } & \multirow{2}{*}{ 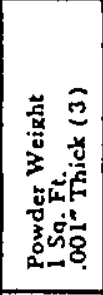 } & \multirow{2}{*}{ 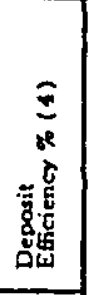 } & \\
\hline & & & & 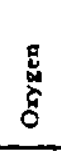 & 递 & 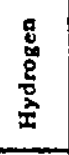 & 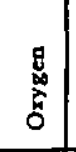 & $\begin{array}{l}\frac{8}{2} \\
\frac{8}{8} \\
\frac{8}{4}\end{array}$ & 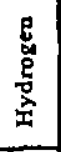 & $\begin{array}{l}j \mathrm{u} \\
\text { ju․ } \\
\text { ud }\end{array}$ & 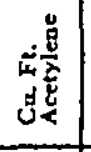 & 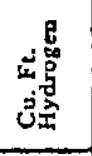 & 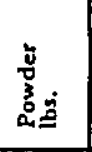 & & & & \\
\hline 1 & 2 & 3 & 4 & 5 & 6 & 7 & 8 & 9 & 10 & 11 & 12 & 13 & 14 & 15 & 16. & 17 & \\
\hline $12 \mathrm{C}$ & P7 & 1 & $8-16$ & 12 & 10 & & 24 & 28 & & 35 & 25 & & 11 & 250 & .044 & 95 & \\
\hline$\cdot 15 \mathrm{E}$ & P7 & 1 & $8-16$ & 12 & 10 & & 24 & 28 & & 35 & 25 & & 11 & 270 & .041 & 95 & \\
\hline (7) $\quad 15 \mathrm{~F}$ & P7 & 2 & $12-16$ & 15 & & 15 & 20 & & 40 & 30 & & 148 & 9 & 215 & .042 & 95 & \\
\hline $\pm 16 \mathrm{C}$ & P7 & 1 & $8-16$ & 12 & 10 & & 24 & 28 & & 35 & 25 & & 12 & 280 & .043 & 95. & \\
\hline $18 \mathrm{C}$ & P7 & 1 & $8-16$ & 12 & 10 & & 24 & 28 & & 35 & 25 & & 10 & 230 & .043 & 95 & \\
\hline $31 \mathrm{C}$ & P7 & 2 & $8-16$ & 12 & 10 & & 24 & 28 & & 35 & 25 & & $7^{1 / 2}$ & 160 & .046 & 95 & \\
\hline (6) $32 \mathrm{C}$ & $\mathrm{P} 7$ & 2 & $8-16$ & 12 & 10 & & 24 & 28 & & 35 & 25 & & 7 & 165 & .043 & 95 & “ \\
\hline (7) $34 \mathrm{~F}$ & P7 & 2 & 8.14 & 15 & & 15 & 20 & & 40 & 30 & & 148 & 7 & 120 & .057 & 90 & \\
\hline $41 \mathrm{C}$ & P7 & 2 & 8-16 & 12 & 10 & & 24 & 28 & & 35 & 25 & & 6 & 145 & $.04 \mathrm{I}$ & 90 & \\
\hline $42 \mathrm{C}$ & P7 & 2 & $8-16$ & 12 & 10 & & 24 & 28 & & 35 & 25 & & $6^{1 / 2}$ & 175 & .037 & 95 & \\
\hline $43 C$ & P7 & 2 & $8-16$ & 12 & 10 & & 24 & 28 & & 35 & 25 & & 7 & 170 & .041 & 90 & \\
\hline 54 & P7 & 2 & $12-14$ & 15 & & 15 & 20 & & 40 & 30 & & 148 & $41 / 2$ & 320 & .014 & 85 & \\
\hline 55 & P7.B & 5 & $13-15$ & 15 & & 15 & 20 & & 40 & 30 & & 148 & 6 & 145 & .042 & 95 & \\
\hline (11) 101 & P7-C. & 5 & $6-12$ & 14 & $\cdot 12$ & & 30 & 30 & & 47 & 28 & & $21 / 4$ & 125 & .018 & 90 & \\
\hline (11) 105 & P7-C & 5 & $6-12$ & 14 & 12 & & 30 & 30 & & 47 & 28 & & 2 & 105 & .019 & 80 & \\
\hline (11) 201 & P7-C & 5 & $6-12$ & 14 & 12 & & 30 & 30 & & 47 & 28 & & $21 / 4$ & 80 & .028 & 80 & \\
\hline$(10)+404$ & $\mathrm{P} 7-\mathrm{B}$ & 5 & $12-14$ & 17 & 15 & & 28 & 28 & & 46 & 28 & & 8 & 185 & .043 & 75 & \\
\hline
\end{tabular}

Thermal Spraying Tables for Metco Type 2P Thermospray Gunl62.L 
Because $i j$ - Cr - B alloys are porous, as sprayed, and will shrink by approximately $20 \%$ when fused, an allowance for tinis sirinicage rust be made when applying the coating.

\section{Tabie 3}

\begin{tabular}{|c|c|}
\hline Surface speed metres/min. & Traverse per revolution \\
\hline 5 & $13 \mathrm{~mm}$ \\
8 & $9 \mathrm{~mm}$ \\
13 & $6 \mathrm{~mm}$ \\
\hline
\end{tabular}

\section{Travel Speeds}

When using hand held guns on stationary work a traverse of $300 \mathrm{~mm}$ should be made within $2-6$ seconds. The width of the strip aimed for at each pass should be between $13 \mathrm{~mm}$ and $18 \mathrm{~mm}$.

\subsubsection{Fusing Technique}

The object of the fusing operation is to convert the porous deposit into a sound, homogeneous coating securely bonded to the substrate. This operation is best carried out while the substrate is still warm from the spraying operation as this will reduce cracking or separation of the unfused coating.

Fusing is carried out by using a conventional oxy-acetylent blowpipe with a large multi-jet nozzle. However, depending on the size of the component being coated, a furnace or induction heating can be used. The flane technique is the most flexible method and can be applied to a wide variety of components. When usinö a blowpipe for neatinö, a carburizing 
flame is used, see FIG. 2.2, because this is a soft flame and will stop the surface coating flowing unevenly:

The substrate and unfused coating snould be heated uniformly to $350^{\circ} \mathrm{C}$ keeping the nozzle a distance of between $100 \mathrm{~mm}$ - $150 \mathrm{~mm}$ away. If the coating is heated too rapidly the coating will expand and separate from the substrate see Plate 2.2.

The nozzle is brought to within $40 \mathrm{~mm}$ of the coating and about $25 \mathrm{~mm}$ from the edge of the workpiece, the flame is. oscillated slightly as the melting point is approached. For the Ni - Cr - B alloy being used, this is between $964^{\circ} \mathrm{C}$ $1003^{\circ} \mathrm{C}(26)$. Once fusion has been initiated, which is shown by a glazing or glassy shine, the torch is moved slowly along the workpiece so that the glazing traverses the whole surface.

The fusing operation should not be interrupted once started. On completion of the fusing operation, the flame is moved back along the surface to ensure that the fused coating has bonded. The thickness. of the deposit can be from $0.05 \mathrm{~mm}$ to $2.5 \mathrm{~mm}$, with a deposition rate of up to $4 \mathrm{~kg} / \mathrm{hr}$.

Slow cooling after depositing the coating is essential to avoid any cracking taking place.

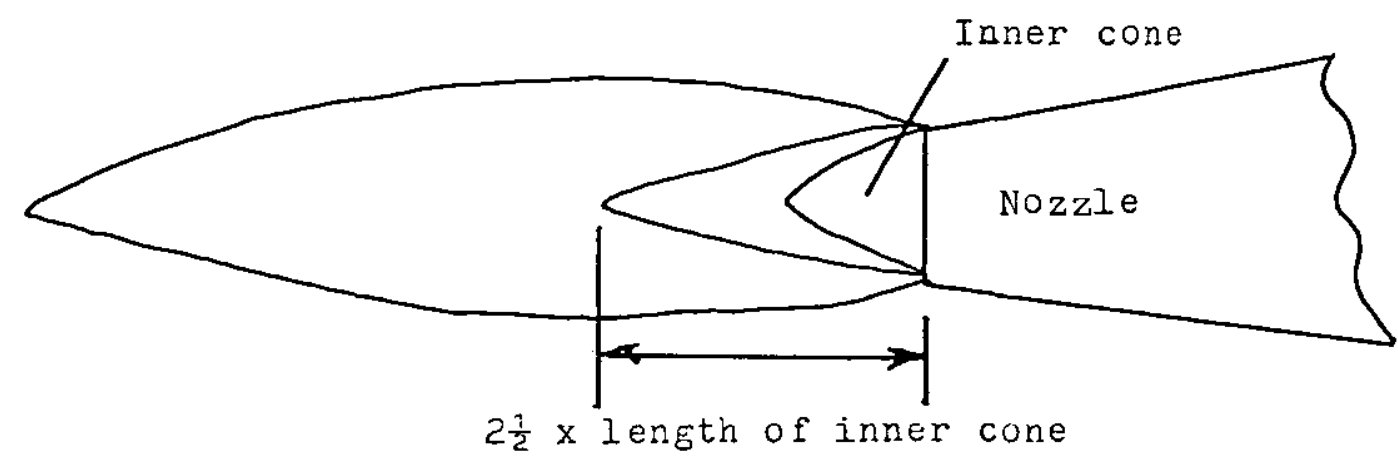

FIG. 2.2 CARBURIZING FLAVE 


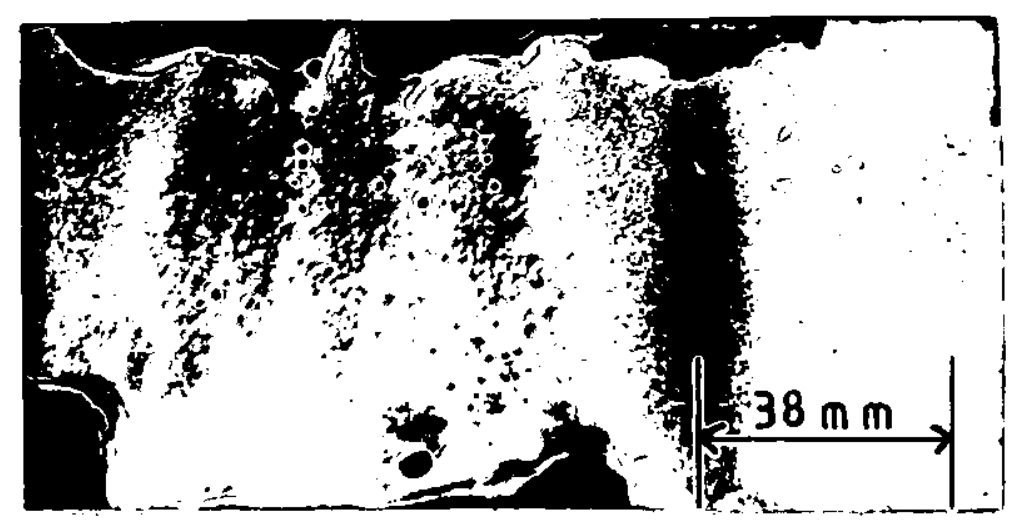

\section{PLATE 2.2 Separation of Fused Coating}

\subsection{Powder Spray Welding}

Powder spray welding is not really a. welding process because bonding takes place by diffusion (46) and the substrate is not melted.

The principle of the Powder welding process is that the powders are induced into a special oxy-acetylene blowpipe FIG. 2.3 and deposited onto the substrate.

The powder spray blowpipe consists of a standard oxyacetylene blowpipe, with a powder feed attachment which has been introduced between the gas control valves and the welding nozzle. The attachment consists of a gas mixing chamber, powder hopper and powder control mechanism.

When the oxygen and acetylene flows through the blowpipe they are mixed in the normal manner in the gas mixing chamber and the mixed gases then flow through into the powder mixing chamber. On depressing the powder control lever the powder is fed into the mixing chamber and is mixed with the 


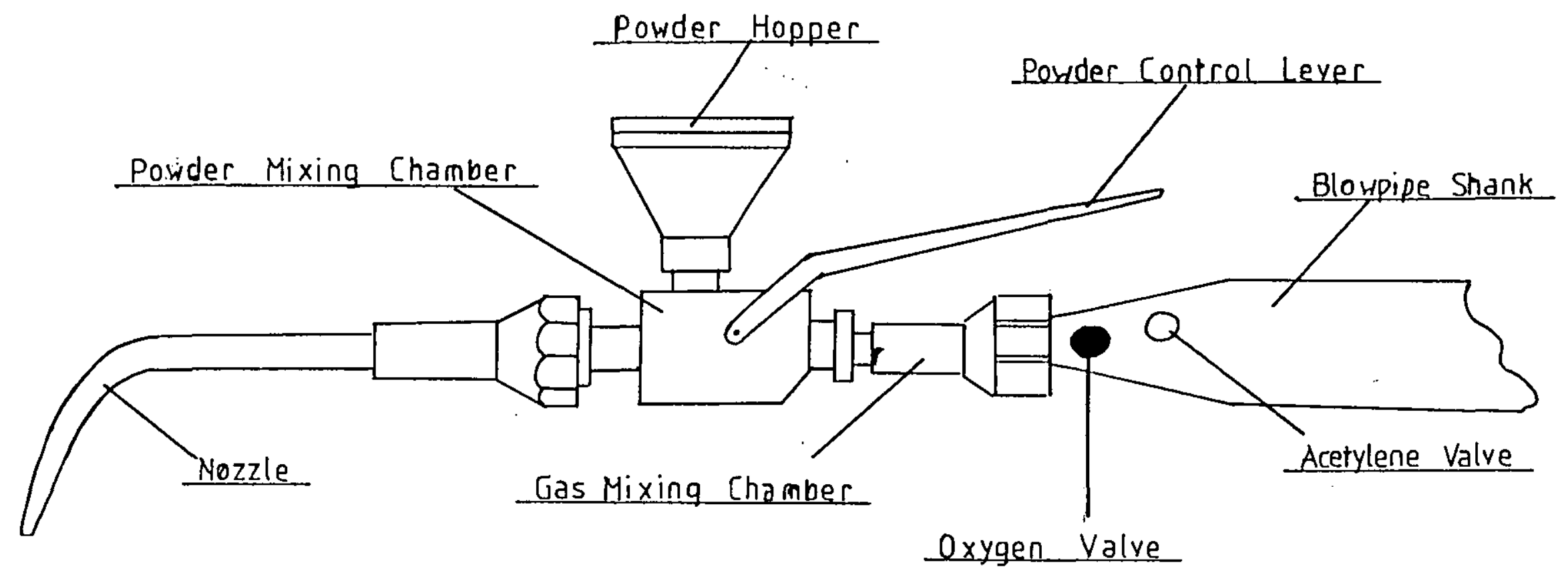

FIG 2.3 Powder spray welding blowpipe 
gas stream. It then jasses throligh a further orifice into the welding nozzle. The powder is oreneated in the inner cone of the flame FIG. 2.2 and, depending on its size and shape, the powder is molten by the time it reaches the substrate to be suriaced.

\subsubsection{Operating Tecinnique}

The regulator pressure settings and nozzle sizes that should be used are shown in Table 4 (6.3).

Table 4

\begin{tabular}{|c|c|c|c|c|}
\hline \multirow{2}{*}{$\begin{array}{c}\text { Nozzle } \\
\text { Size }\end{array}$} & $\begin{array}{c}\text { Oxygen } \\
\text { p.s.i. }\end{array}$ & $\begin{array}{c}\text { Acetylene } \\
\text { p.s.i. }\end{array}$ & \multicolumn{2}{|c|}{ Average Consumption $\mathrm{ft}^{3} \mathrm{~h}$} \\
\cline { 3 - 5 } & & Oxygen & Acetylene \\
\hline 7 & $8-10$ & $8-10$ & 11 & 10 \\
10 & $10-12$ & $10-12$ & 12 & 11 \\
13 & $12-15$ & $12-15$ & 13.5 & 12.5 \\
\hline
\end{tabular}

Regulator Pressure Settings and lozzle sizes

The flame is set to the carburizing condition, see FIG. 2.2. After preneating tine substrate to $500^{\circ} \mathrm{C}$ it is then brought to its fusing temperature. To avoid oxidation and to help minimize dilution, an initial layer is sprayed lightly and rapidly over the substrate surface. This is an effective way of securing the coating to the substrate during fusing. Otherwise oxidation has a tendency to prevent proper diffusion, leaving the coating still separate from the substrate $(34)$

The facing rlins are carried out with the travel direction from right to left, leftward tecinique $(64,65)$.. A small area of the slibstrate slirface is neated until it begins 
to show sizns of melting. At this time a small amount of powder is sprayed onto the surface and the flame is held there until tine alloy fuses. Tris procedure is repeated until the whole surface is covered.

On large surfaces a slight weaving action, with a travel distance $0 i$ between $20 \mathrm{~mm}-25 \mathrm{~mm}$ is used. Powder is introcuced on the olitward weaving motion and heat alone is applied on the inward motion. This method appears to be more suitable than using straight narrow beads.

The thickness of the deposit is governed by the rate of flow of powder and movement of the blowpipe. This can be from $0.05 \mathrm{~mm}$ to $3.0 \mathrm{~mm}$ thickness, with a deposition rate of up to $5 \mathrm{~kg} / \mathrm{hr}(46)$.

After depositing the alloy to avoid the possibility of cracking slow cooling is essential.

\subsection{Oxy-acetylene welding}

The oxy-acetylene welding consists essentially of melting the "as cast" hardfacing rod, by means of a conventional oxy-acetylene blowpipe and depositing it onto the substrate, whose surface is kept just above the hardfacing alloy!s melting point. The process is sometimes described as brazed welding ( 9 ) rather than fusion welding. As the substrate does not become molten, dilution is kept to a minimum.

\subsubsection{Operating Technique}

The regulator pressure settinis anc nozzle sizes are the same as those for Powder spray welding, see Table 4. The flame is adjusted to the carburizing condition, see FIG. 2.2. After preheating the substrate to $500^{\circ} \mathrm{C}$ the surface is brought to its fusing temperature. Care whst be taken with grey cast iron because its surface does not "sweat" to indicate 
that the fusing temperature is being reached and the iron may easily saf or melt. It is advantaoous therefore, when coating grey cast iron with this process, to rapidly deposit a very thin layer on the surface. This will practically eliminate dilution in the second layer and stop the substrate from sagging or melting̈.

The direction of travel is the leftward technique (64, 65) with the angle of the blowpipe at $60^{\circ}-70^{\circ}$ to the workpiece and the angle of the hardiacing rod at $60^{\circ}$, see FIG. 2.4 .

A slight weaving action of tine blowpipe, to produce deposits of approximately $25 \mathrm{~mm}$ wide, appears to be more successful when coating large areas than using straight narrow beads.

The deposit. thickness can be from $1.0 \mathrm{~mm}$ up to $5.0 \mathrm{~mm}$ depending on the diameter of the harufacing rod used and the number of layers deposited. The deposition rate is slow with a maximum of $\mathrm{l} \mathrm{kg} / \mathrm{hr}$ (46). Due to the high heat input to the workpiece distortion or warping can occur.

After depositing the coating slow cooling is essential to avoid any cracking taking place.

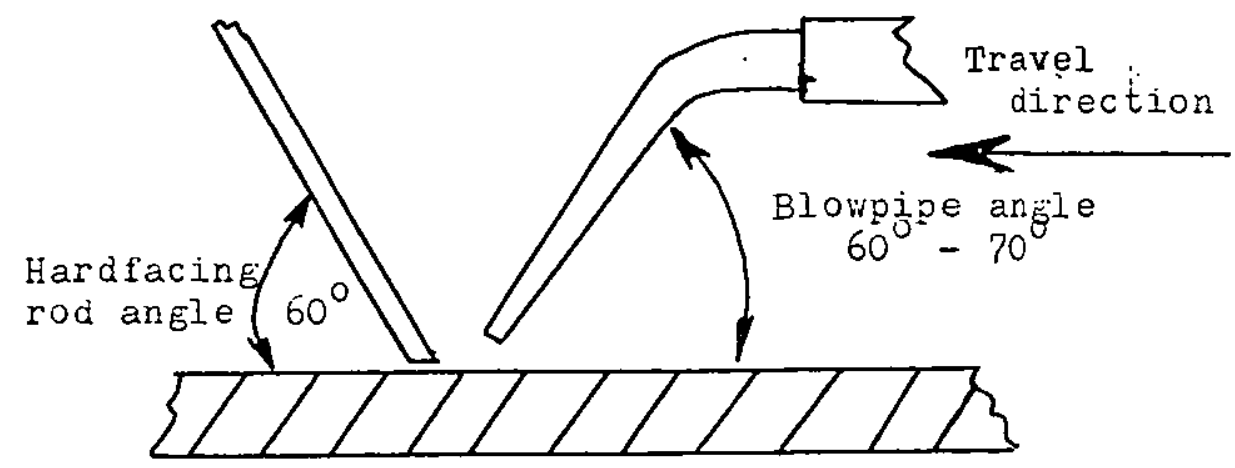

FIG. 2.4 ANGLE OF HARDFACING ROD AND BLOUPIPE 


\subsection{Tungsten Inert Gas iielding}

The tlingsten arc process was introduced after tine secund World War ard has since found its place supplementing the other surfacing wetinods (13).

The process uses a thoriated tungsten electrode (66) shrouded by an inert gas shield, which is usually argon. An arc is struck between tine tungsten electrode and the work and argon is fed. around the tungsten electrode which is only slowly consumed.

The hardiacing alloy is deposited from an "as cast" rod in the same way as oxy-acetylene welding but the heat is rore concentrated. Usually the process is operated manually but it can easily be mecinanised (46). 2.4.1 Operating Technique

The tungsten electrode is connected to the negative. (-) pole of a Direct Current (D.C.) welding transformer. The welding current must be kept as low as possible (and the voltage as high as possible) because increasing the current by $33 \%$ will cause a mean increase of $90 \%$ in the depth of penetration into the substrate. The voltage should be as high as possible because the higher the voltage the less agitated the weld pool will be and the smaller will be the depth of penetration achieved. Depths of penetration of $0.6 \mathrm{~mm}-0.8 \mathrm{~mm}$ can be achieved in this way (67).

The largest dianeter of hardfacing rod, acceptable for the operation being carried out, sholild be used because it will reduce some of the contamination from the tungsten electrode.

A D.C. current of between $100 \mathrm{~A}$ and $200 \mathrm{~A}$ should be used and the tip of the electrode sholid be ground to an ariele of 
$60^{\circ}-90^{\circ}$ with the end rounded of $\hat{f}$, see FIG. 2.5.

The direction of travel is the leftward technique and the angle of the welaing torch should be held between $60^{\circ}-70^{\circ}$ to the workpiece. The hardfacing rod should be held at an angle of $60^{\circ}$, see FIG. 2.4. The weld pool inust not be pudded as this will increase the dilution. Straight, narrow beads are deposited quickly and overlapping each other as shown in FIG. 1.3. This technique limits the dilution with the substrate. At the end of each bead the arc should not be lengtinened quickly because the crater that is formed becomes oxldised due to the lack of shielding gas.

The deposit thickness can be from $1.6 \mathrm{~mm}$ up to $5.0 \mathrm{~mm}$ and the deposition rate up to $2 \mathrm{~kg} / \mathrm{hr}$. With the heat input being concentrated only minimal distortion or warping of the substrate occurs. After depositing the alloy, slow cooling is essential to avoid craching taking place.

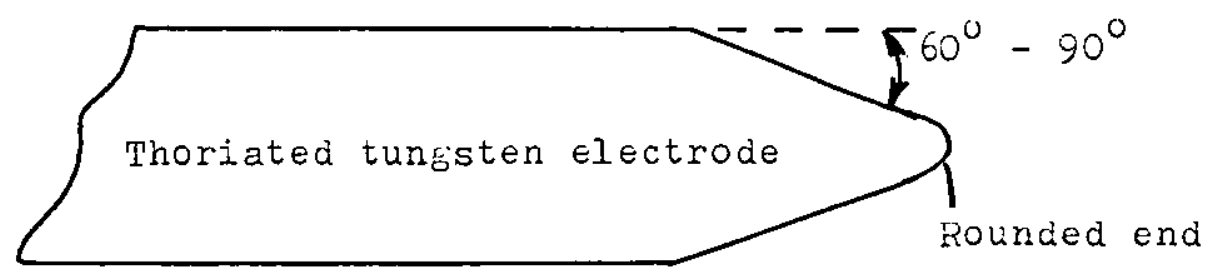

FIG. 2.5 PREPARATION OF THE TUEGSTEN ELECTRODE 
CHAPTER 3

EXPERIMENTAL WORK 


\section{CHAPTER 3}

\section{EXPERIMENTAL WORK}

As the main oojective of the investigation was to establish the most effective method for depositing a hardfacing alioy onto a grey cast iron substrate, it was necessary to establish a procedure for assessing the quality of the coating. The principal attribute of tine hardfacing alloy is its ability to withstand abrasive wear and consequently wear testing of the applied coating was considered to be the most appropriate method of assessment. Hardfaced coatings are extremely hard, but this hardness may be adversely affected if the alloy is diluted by the substrate. It was therefore considered that the measurement of hardness, both surface and macro, should be complemented by Electron probe micro analysis (EPMA) which would measure the percentage of the elements across the deposit/ substrate interface area and could provide an indication of tine presence and degree of dilution of the hardfacing alloy by the substrate. The integrity of the bond between the substrate and hardfacing alloy is clearly an important consideration. In extreme cases it is possible for separation of the coating to occur.

It was considered that an optical microscopy study of the specimens sectioned through the hardfacing/substrate interface should be conducted to provide information about the integrity of the interface.

\subsection{Abrasive Wear Testing}

Reddy and Nau (68), in their review of wear tests, classify vear test conditions under the following headings. 
1. Rolling Contact

2. Simultaneous Rolling and Sliding

3. Localised Sliding Contact

4. Extended Sliding Contact

5. Abrasion

6. Oscillatory

An abrasive wear test will be used in this investigation and aorasion was discussed earlier in 1.6 .1 .

Abrasion resistant coatings create unique structures. These structures are comprised of at least one coating material bonded to a substrate. The testing problem, therefore, is much more complex than the testing of solid materials because in addition to the combined properties of the coating and the substrate involved the bond conditions between the two must be considered. In addition internal stresses, which result from the differences in physical properties of the materials, must be considered.

Ideally, wear tests should reproduce as closely as possible the fundanental conditions of actial service. A scratch test is usually employed to simulate abrasion and give a more complete understanding of the mechanisms oí abrasive wear (69).

The abrasive wear tests in the investigation were carried out on a reciprocating̈ diamond scratch testing machine (70), Plate 3.1 and FIG. 3.1 in which a right circular cone of diamond with a circular tip radius $(0.2 \pm 0.01 \mathrm{~mm})$ and an inclined angle of $120^{\circ}$ was the abrasive element.

To carry out the scratch tests five specimens from each of the 1 layer deposits, 2 layer deposits and control samples, measuring $76 \mathrm{~mm} \times 55 \mathrm{~mm}$, were cut from surface ground blanks, FIG. 3.2. These were then individually clamped onto the 
reciprocating carriage and set to the required stroke lengtin. The load required was placed onto the load plate to apply load to the diamond. The number of strokes required were set on a counter with an automatic-stop device. This facility ensured that the tests were stopped autouatically when the preset number of reciorocations had been reached. A perspex cover was placed over the top of tine testing macrine to isolate the wear tests from the amoient environment.

The literature survey showed no comparable scratch testinf conditions on hardfacing alloys so the test parameters used, closely followed those of Gibson (70) and Razavizdeh and Davies (71.) these were:

$\begin{array}{lll}\text { Stroke length } & : & 40 \mathrm{~mm} \\ \text { Loads } & : & 2.5 \mathrm{~kg}, 5 \mathrm{~kg}, 10 \mathrm{~kg} \\ \text { Average linear speed } & : & 3.33 \mathrm{~cm} / \mathrm{sec} \\ \text { No. of strokes } & : & 10,50,100,500\end{array}$

The results were obtained in tine form of a "wear volume" which was proportional to the width of the scratch.

The formula used was: $(70,71)$

Wear volume $=\left(0.144 \mathrm{~W}^{2}-1.63 \times 10^{-3}\right) \times \mathrm{L}$ winere

$W=$ Scratch width and

$L=$ Stroke length

The formula was derived as shown in FIG. 3.3 and Appendix 1. Scratch widths ( $(i)$ were measlired at $8 \mathrm{~mm}$ intervals along the length of the scratch using an Engineer's microscope at the position snown in FIG. 3.4 in order to avoid erroneous results due to the measurement from the peaks of the piled up edges.

The diartond was thoroughly cleaned with industrial spirit prior to each test. 


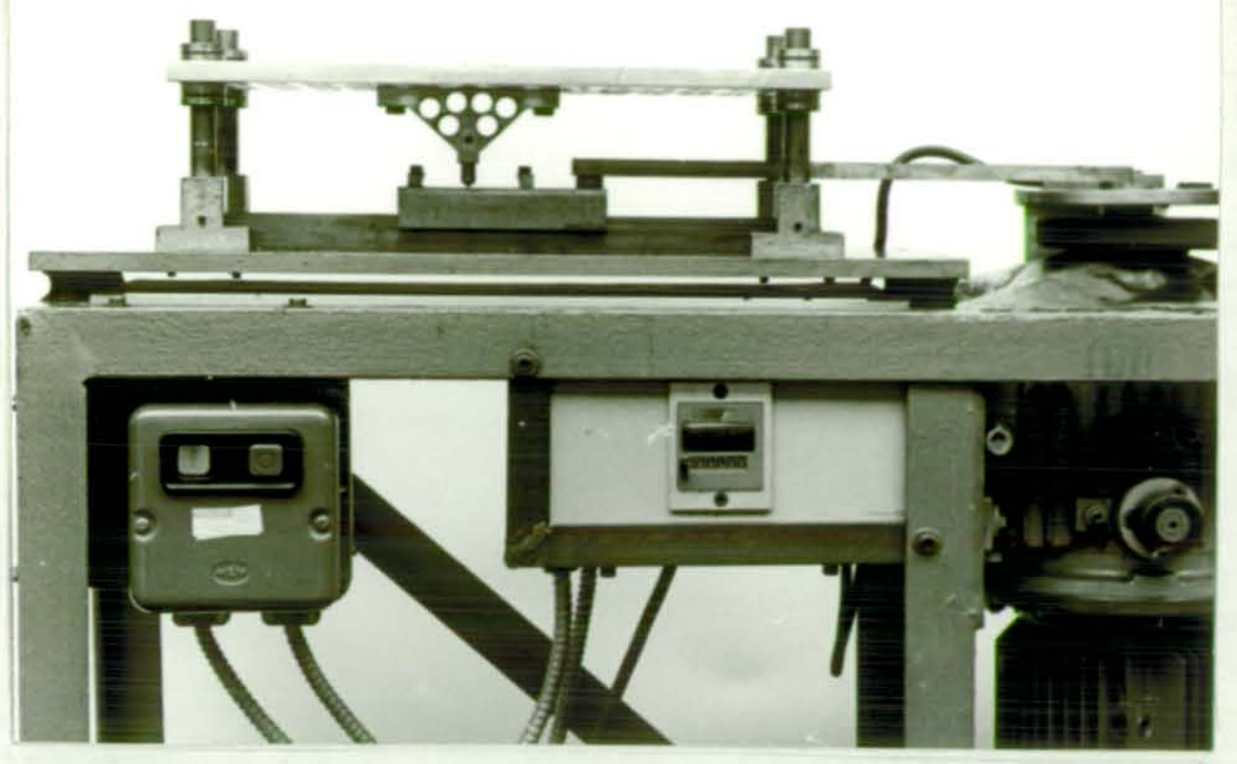

PLATE 3.1 Reciprocating Diamond Scratch Testing Machine

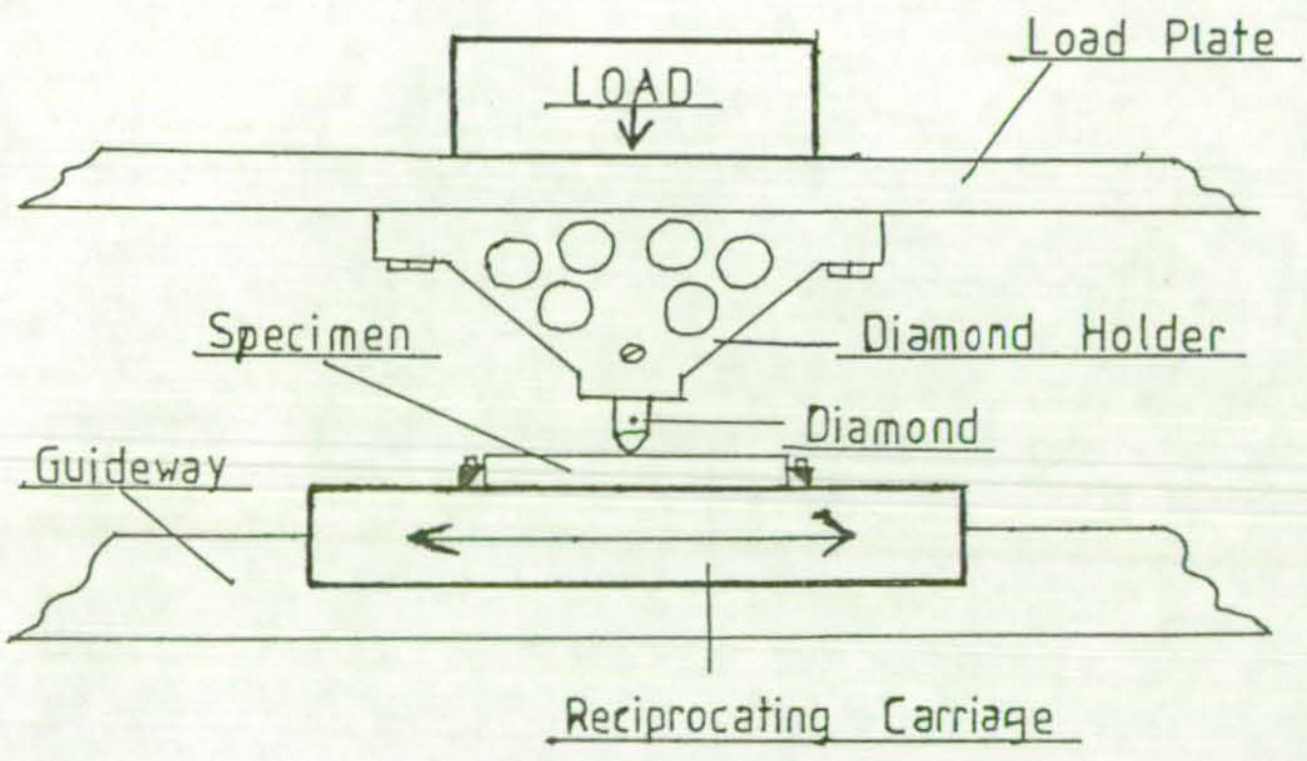

FIG 3.1 Detail of Diamond Scratch Testing 


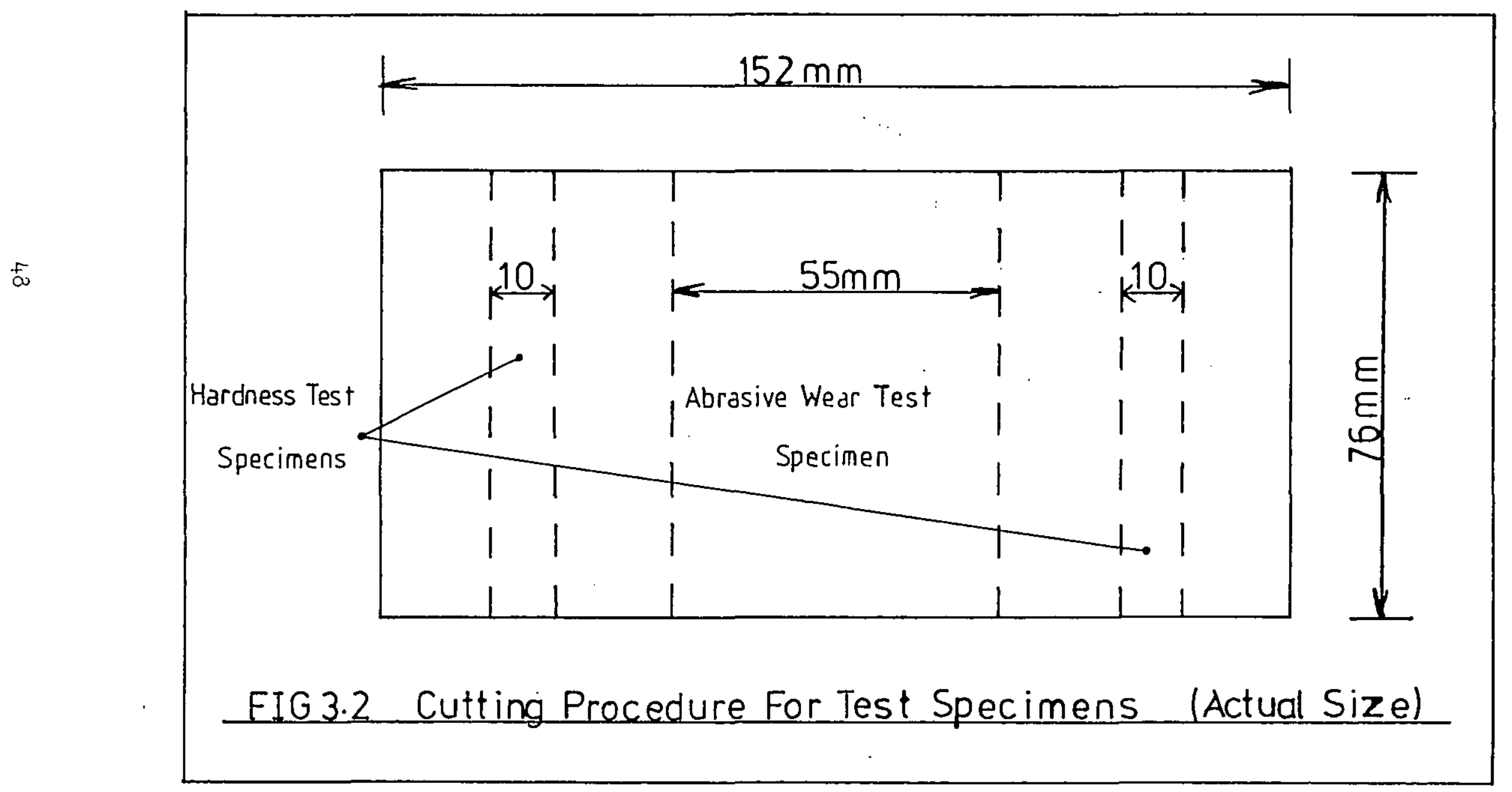



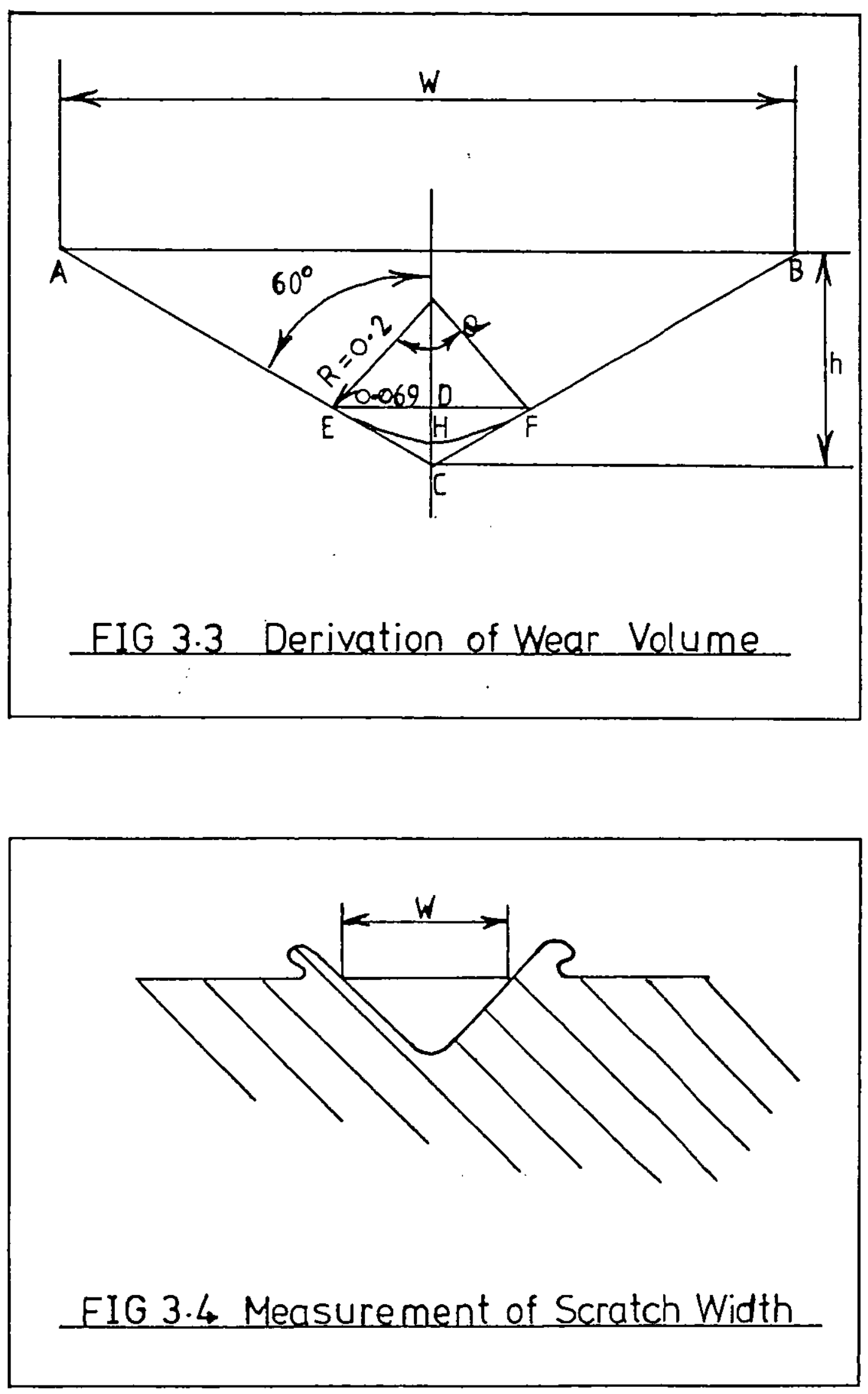


\subsection{Hardness Testing}

Hardness is the property possessed by a metal resisting scratcining or indentation. It is measured on various scales, the most common of which are: Brinell, Rockwell and Vickers. When these hardness tests are used on hardfaced coatings, they are influenced by the hardness of the alloy particles, the bond between particles, the porosity of the deposit and the oxide content. The surface hardness is a poor guide to abrasive Iife which depends directly on the structure of the alloy. For this reason the following tests were selected so that the overall hardness characteristics of the alioy could be measured:

1. Surface hardness

2. Macro hardness

\subsubsection{Surface Hardness}

Five specimens from each of the control samples, 1 layer deposits and 2 layer deposits were surface ground to provide a uniform finish and then tested for their surface hardness. In the absence of a Brinell Hardness Testing machine a Rockwell Hardness machine, with a ball indentor, was used. Each specimen was tested five times. The control samples were tested on the $B$ scale but vecause of the hardness of the hardfaced specimens it was necessary to use the $\mathrm{C}$ scale. So that a comparison could be made with the other hardness tests being: undertaken the hardnesses were converted into equivalent Vickers Fardness (HV).

\subsection{E Macro Hardness}

In order to give ar indication of the total hardness of the dejosited coating, five specimens fros each of the 1 layer deposits and a layer deposits were tested to neasure tine 
hardness profile across tine interface. The tests were carried out using a Vickers. Pyramid hardness tesing machine, with a $1 \mathrm{~kg} l o \mathrm{ad}$ and a 2/3" objective.

To prepare the specimens for the macro hardness tests, each specimen was molnted in a bakelite material. The specimens were then ground successiveiy through wet and dry silicon carbide papers, grades $220 \mu \mathrm{m}$ - $600 \mu \mathrm{m}$ to eliminate any scratches. The specimens were then washed with water and dried with metianol. To give the specimens a highly poiished finish they were polished on a rotating pad which was impregnated with a $3 \mu \mathrm{m}$ diamond compound. After polising the difference between the deposited coating and the substrate could be clearly seen, so no etching of the surface was required.

Ideally for comparison purposes the hardness measurements should be made at similar distances from the starting point for each of the specimens, but some dificiculty was encountered in setting the testing machine, so the measurements were taken as near equal as practicable for comparability.

\subsection{Optical Microscopy}

Spraying and welding processes provide difference deposition methods, heat inputs and cooling rates wich affect the structure of the deposited alloy, the integrity of the bond between the hardfacing alloy and the substrate, also burning: out of essential elements from the cast iron substrate is possible. To provide information on these aspects it was considered necessary to produce photomicrographs. The photomicrographs were produced at a magnification of $200 x$, using a Nikon microscope.

Preparation of the specimens followed the same order as for the macro hardness test specimens, except that aiter the final 
polishing the specimens were etched by immersion in solutions of Murakamis reagent and mixed acids for a period of 2 minutes in eacin solution.

Murakamis reagent

$10 \mathrm{gms} \mathrm{K} 3 \mathrm{Fe}(\mathrm{CN}) 6,10 \mathrm{gms} \mathrm{Na} \mathrm{OH,} 100 \mathrm{ml}$ H2O

Mixed acids

$15 \mathrm{ml}$ Acetic acid, $15 \mathrm{ml}$ HNO3, $60 \mathrm{ml}$ Elycerol

The etchants were chosen because Okada and Maruo (72) had used them on a $\mathrm{Ni}$ - Cr - B alloy to show similar structures. The Murakamis reagent was used to show the carbide particles in the alloy and the mixed acids to show the boride particles and the matrix of the alloy.

\subsection{Electron Probe Nicroanalysis (EPMA)}

Five specimens from each of the 1 layer and 2 layer deposits produced by each process were selected for EPMA. However, because of tine operator's work load, only l specimen from each of the 1 layer and 2 layer deposits, for each process, were examined.

The specimens were exanined to measure approximate percentages of the elements: $\mathrm{Ni} ; \mathrm{Cr} ; \mathrm{Si}$ and $\mathrm{Fe}$ across the interface area and provide an indication of the presence or degree of dilution of tine hardfacing alloy by the substrate.

preparation of the specimens followed a procedure similar to that for macro hardness test specimens 3.2.2. The barkelite material used for mounting the specimens is usually suitable for EPMA, but it was found to be non-conductive, and the specimens had to be coated with carbon to conduct the electrons away during analysis in urder to stop charging. Because of the difference in coating thicknesses produced by the different processes the EPMA probe travelled 
varying distances across the interface. For all the specimens the readings on the chart started at $240 \mu \mathrm{n}$ below the fusior line into the sibstrate and then tine average peak measurenents were taken every 120 urn until the peaks snowed a constant level.

The chart speed was $10 \mathrm{~mm} / \mathrm{min}$ and the specimen speed was $10 \mu \mathrm{m} / \mathrm{min}$.

The formula used to establish the approximate element percentage was:

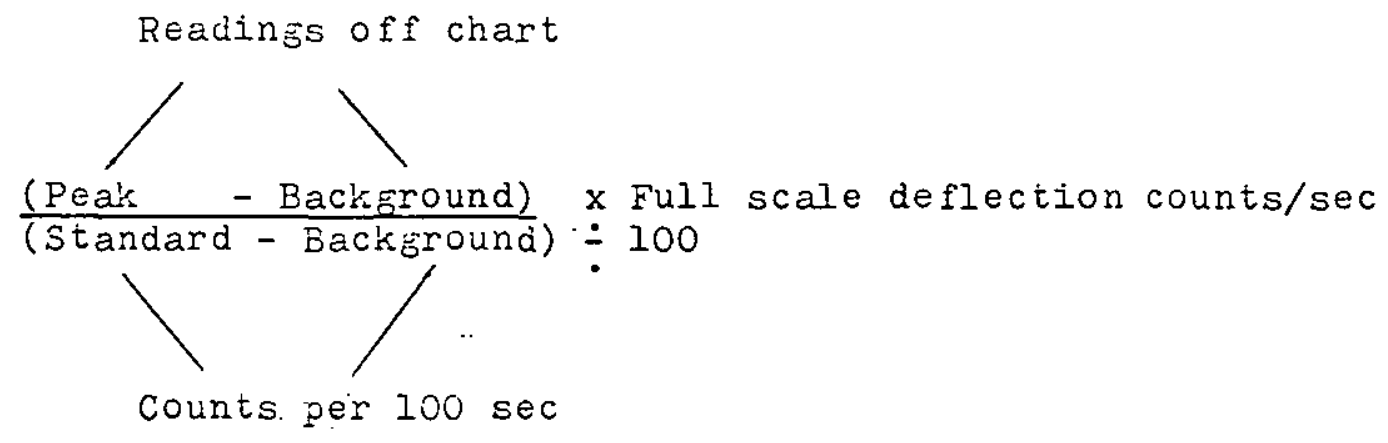

\subsection{Preparation of Specinens for the Hardfacing Experiments}

\subsubsection{Production of the substrate}

Cast iron blanks were produced by the green sand moulding process using cast iron melted in an oil-fired Morgan tilting crucible furnace. The as-cast size of these blanks was: $152 \mathrm{~mm} \times 76 \mathrm{~mm} \times 13 \mathrm{~mm}$. The analysis of the cast iron $\operatorname{vas}(2): \quad \mathrm{c} 3.22 \%-3.32 \%$, Si $1.97 \%-2.08 \%$, N $1.56 \%-1.66 \%$, P $0.104 \%-0.137 \%$, s $0.036 \%-0.038 \%$.

\subsubsection{Preparation of the Substrate Surface}

The as-cast surface of the cast iron blanis was renoved by surface grinding to produce a standardized surface. In all cases this required tine removal oí $0.5 \mathrm{~mm}$ of $\mathrm{f}^{\prime}$ the material.

The surface grinding was crried out usine a grindinö wheel number WA $60-J 6-V$ and a speed of 3500 surface feet per minute, and the coolant used was a 1:40 soluble oil emulsion. 
After surface örindin̈̈, the blanss were diried and tnen grit blasted iou 4 minutes on tine surface where the alloy was to be cejusiteu, hsing Gjy grit in a Tilghman theelabrator macinine. At tinis stäge tine blanks were then reaciy for the hardiacing operations.

\subsection{Hardfacing Operations}

BS 1295 : 1959 (73), for buildin̈̈ up surfaces by Oxjacetylene and ianual netal arc weiding processes, was followed as closely as possible.

\subsubsection{Thermal spraying}

The conditions used for the setting up procedure for the spraying uperation followed the guide lines recommended by the spray gun manufacturer given in Table $z$ these were: Flow ieter pressure settings

Oxygen $\quad: \quad 24$ p.s.i. ( 1.80 bar $)$
Acetylene $\quad: \quad 28$ p.s.i. ( 2.10 bar)

\section{Lighting pressure settings}

$\begin{array}{ll}\text { oxygen } & : \quad 12 \mathrm{p} . \mathrm{s} . \mathrm{i} .(0.90 \mathrm{bar}) \\ \text { Acetylene } & : \quad 10 \mathrm{p} . \mathrm{s.i} .(0.75 \mathrm{bar})\end{array}$

Flow control valve setting

14 clicks

Nozzle size

P 7

The cast iron blank, which had been surface ground and then grit blasted, was placed in an upright posicion on the work bench for ease of spraying and surrourcied on three sides with fire bricks to contain the heat. The $\mathrm{Ni}-\mathrm{Cr}-\mathrm{B}$ powder Deloro* 60 s was poured into the carister on the therinal spray

* Deloro is a registered trade mark of Deloro stellite (UK) Ltd. 
gun FIG. 2.I. Using the flowmeter and lighting presslire settinz̆s given, the flame wäs ignited. This flame was used to preheat ine cast iron blank to $93^{\circ} \mathrm{C}$, a digital surface contact themometer was lised to check the temperature. Once tine preneating temperature nad been reached the flow control valve was set to 14 clicks. The jowder was then sprayed horizontally across the blank to form a strip width of approximately $18 \mathrm{~mm}$ this was continued by overlapping the strips until the whole surface had been covered. The travel speed for each strip was approximately 3 seconds and the whole surface required approximately 30 seconds to cover. This proceaure was repeated, for the 2 layer deposit.

After spraying, the blank was placed in the flat position, so that when fusing occurred it would avoid sagging or runring of the ailoy.

A conventional blowipe with a multi jet nozzle was used for the fusing operation and used the same Iighting pressure settings as the flame spray gun. The tlame was set to the carburizing condition FIG. 2.2 to stop the surface coating flowing unevenly. To stup the coatin̈̈ cracking or separating, the flising operation was carried out while the blank was still warm. The nozzle was kept at a distance of approximately $100 \mathrm{~mm}$ away from the blank to stop the coating heating up too rapidly. The coating was tinen brolight to a uniform temperature of $350^{\circ} \mathrm{C}$, this temperature was cinecked usine the digital sliriace contact thermomezer and then the nozzle was bruught to within $40 \mathrm{~mm}$ distance from the coatine and $25 \mathrm{~mm}$ in from the edoe of the blank. As the melting point of the alloy was being approached tire flane was oscillated slightly. when the meltine temperature was reached, visible by a glassy 
snine, the flame was moved along the blank until all the surface was fused.

After deposition the blank was placed in a container, covered vith sand and allowed to cool slowly for 5 hours. 3.6.2 Powder Spray welding

The setting up procedure for the spraying operation, followed the glide lines set down by the spraying equipment manufacturers, Table 4, these were:

Regulator pressure settings

$\begin{array}{lll}\text { Oxygen } & : & 12 \mathrm{p} . s . i(0.90 \mathrm{bar}) \\ \text { Acetylene } & : & 12 \mathrm{p.s.i}(0.90 \mathrm{bar}) \\ \text { Nozzle size } & & \end{array}$

13 (swaged type)

The cast iron blank, which has been surface ground and then grit blasted, was placed flat on the work bench and surrounded on three sides by fire bricks to contain the heat. The Ni - Cr - B yowder Deloro 60 s was poured into the hopper FIG. 2.3. The flame was ignited and adjusted to the carburizing condition and used to preheat the cast iron blank to $500^{\circ} \mathrm{C}$. A digital surface contact thermometer was used to check the temperature.

After preheating, the cast iron was brought to its fusing. temperature with the inner cone of the flame, FIG. 2.2, approximately $6 \mathrm{~mm}$ away from the cast iron. At tinis stage the powder control lever was depressed to release the powder and a very light lajer was rapidly sprayed onto tine cast iron surface to prevent oxidation. A small area of the cast iron was then heated until it showed signs of melting. At this point a small amount of powder was released and sprayed onto the cast iron surface and the flame was held there until the powdered 
alloy melted and fused. Travelling̈ irom right to left, and lising a slight weaving action to produce a deposit widtin of approximately $20 \mathrm{~mm}$, the yowder was introduced on the outward weaving motion and tine heat alone on the inward motion. This procedure vas carried olit lintil all the surface had been covered. For the 2 layer deposits the whole procedure of covering the surface was repeated.

After deposition the blanis was placed in a container, covered with sand and allowed to cool slovily for 5 hours.

\subsubsection{Oxy-acetylene :ielding}

The procedure for setting up the equipment followed that of tine Powder spray welding, except that the powder nopper attachment was replaced with a conventional welding blowpipe.

The cast iron bläk was placed in the flat pusition on top of a fire brick on the work bench, no other fire bricks were used to surround the blank, because easy access was required for the welding blowpipe and feeding in of the riller rod. The flane was ignited, then set to the carburizing concition and used to preheat the cast iron blank to $500^{\circ} \mathrm{C}$, a digital suriace contact thermometer was used to check the temperature. After preheating, the surface of the blank was brought near to its iusing temperature. Care had to be exercised because cast iron does not sweat to indicate its fusion temperature is being reached, instead it starts to sag or welt away.

The blowipe was traversed in a direction from right to left at an angle oi $60^{\circ}$ to the cast iron, FIG. 2.4. At this pint the $5.0 \mathrm{~mm}$ diameter $\| \mathrm{I}-\mathrm{Cr}$ - B as cast rod, winich was ineld at an angle of $60^{\circ}$, was fed into the flame and melted unto the cast iron surface. A slight weaving motion vith the 
blowpipe pruciliced a fused deposit oi approximately $\bar{c} 5 \mathrm{~mm}$ width. This procedire was repeated until all the suriace had been covered. For the $\hat{c}$ layer deposits the method used for the 1 layer deposit was repeated.

After deposition the blank was placed in a container, covered with sand and allowed to cool slowly for 5 hours. 3.6.4 Tungsten Irert Gas ielding

Tile conditions for tinis process were found by preliminary experiments to be:

ADR $200 \mathrm{AC} / \mathrm{DC}$ welding transformer

Set to Direct Current (DC)

Velding current

120 Amperes

Voltage

75 volts

\section{Tungsten electrode}

$3.0 \mathrm{~mm}$ diameter: Thoriated with the tip ground to an angle of $60^{\circ}$ with the end rounded, see FIG. 2.5.

Gas shield

Argon : Set to a flow rate of 30 litres per minute

The cast iron blank was placed in the flat position on a metal work bench so that the arc could be initiated. No fire bricks were used to surround the blank because easy access was required for the relding torch and feeding in of the filler rod. Using a multi jet nozzle on the oxy-acetylene vielding blowpipe the flame was ignited and adjusted to the carburizing condition. The cast iron blank was then preneated to $500^{\circ} \mathrm{C}$, a digital surface contact thermoweter was used to checis the temperature.

After preheating, an arc was struck beiveen the tungsten 
electrode and tine cast iron. The angle of the welding torch was held at $60^{\circ}$ to the cast iron and a weld pool was formed. The $5.0 \mathrm{~mm}$ diameter iii - $\mathrm{Cr}-\mathrm{B}$ as cast rod was dipped into the weld pool, the angle of rod was held at $60^{\circ}$. The travel direction was from right to left and straight narrow beads were deposited. The beads were overlapped into each other, see FIG. 1.3, and at the end of each bead the arc was length: ened slowly to avoid oxidation of the weld pool. This prucecure was repeated until all the surface had been covered. For the 2 layer deposits the cast iron blank was turned $180^{\circ}$ and the method repeated as for the 1 layer deposit. The blank is turned $180^{\circ}$ because at the end of tine weld bead a crater or flat area forms and if all the lajers were deposited in the same direction the surface build up wolid be unequal.

After deposition the blank was placed ir a container, covered with sand and allowed to cool slowly for 5 hours. 3.7 Surface Grinding after Deposition

After the hardfacing alloy had been deposited and cooled tine coating was surface ground to provide a smooth uniform finish. It was not possible to surface grind the blanks to an equal thickness because of the different thicknesses of the deposited coatings. The I layer Thermal sprayed deposits were too thin to surface grind so the wear and hardness tests were carried out on the as-deposited coating.

Tine surface grinding was carried out using a grinding wheel number C60-K6-VE with a wheel speed of 3500 surface feet per minute and the coolant used was a 1:40 soluble oil emulsion.

After surface grinding the blanks the specimens for the tests were cut to size, see FIG. 3.2. This was carried out 
on a power nacksaw, cutting from the cast iron down to the hardfaced coating and then snapping of the test specimens. The rough edges were slirace ground smooth. Following preparation, the specimens were ready for the subsequent test procedures and tine results of these experiments are provided in the next chapter. 
CHAPTER 4

RESULTS 


\section{CHAPTER 4}

\section{RESULTS}

\subsection{Abrasive : :}

The wear testing irogramme, the procedure for which was described in section 3.1, generated a very large amount of data. To aid interpretation the data has been treated in the following way:

The data for the control and the four hardfacing processes has been separated accordint to the number of scratches in the abrasive wear test procedure, namely: 10; $50 ; 100$ and 500.

After each abrasive wear test the scratch width was measured at $8.0 \mathrm{~mm}$ intervals along the $40 \mathrm{~mm}$ scratch length and from this information an average wear volume value was determined. Each test was repeated five times and the average wear volume obtained from the five tests was used to produce graphs relating wear volume to wear test Ioad. 4.1.1 Control Data

The averase wear volume values for the cast iron substrate material are provided in tabular form in Tables 5 to 8 for 10 , 50, 100 and 500 scratches respectively. This information is summarised Eraphically in FIG. 4.1 and the detailed results are provided in Tables 1 to 4 in Appendix 2 .

For comparison purposes the appropriate wear volume versus load relationsinip for the cast iron substrate is included in the graphical results for the hardfacing processes.

\subsubsection{Hardfacing Processes}

For each process the average wear volume values for the 1 layer and layer deposits are provided in tabular form with 
the detailed results presented in Appendix 2. The information for both deposits is also summarised Eraphically. The relevant Table and $\vec{F}$ igure numbers are presented below:

\begin{tabular}{|c|c|c|c|c|c|}
\hline $\begin{array}{c}\text { Number } \\
\text { of } \\
\text { Scratches }\end{array}$ & \multicolumn{2}{|c|}{$\begin{array}{c}\text { Average iear } \\
\text { Volumes } \\
\text { Table iumbers }\end{array}$} & $\begin{array}{c}\text { Detailed Results } \\
\text { Appendix 2 } \\
\text { Table Numbers. }\end{array}$ & $\begin{array}{c}\text { Grapnical } \\
\text { Summarisation } \\
\text { Figure ivuber }\end{array}$ \\
\hline & 1 Layer & C Layers & I Layer & 2 Layers & \\
\cline { 2 - 6 } 10 & 9 & 10 & 5 & 6 & 4.2 \\
50 & 11 & 12 & 7 & 8 & 4.3 \\
100 & 13 & 14 & 9 & 10 & 4.4 \\
500 & 15 & 16 & 11 & 12 & 4.5 \\
\hline
\end{tabular}

Thermal Spraying Frocess

\begin{tabular}{|c|c|c|c|c|c|}
\hline $\begin{array}{c}\text { Number } \\
\text { of } \\
\text { Scratches }\end{array}$ & \multicolumn{2}{|c|}{$\begin{array}{c}\text { Average Vear } \\
\text { Volumes } \\
\text { Table Numbers }\end{array}$} & \multicolumn{2}{|c|}{$\begin{array}{c}\text { Detailed Results } \\
\text { Appendix 2 } \\
\text { Table Numbers }\end{array}$} & $\begin{array}{c}\text { Graphical } \\
\text { Summarisation } \\
\text { Figure Number }\end{array}$ \\
\hline & 1 Layer & 2 Layers & 1 Layer & 2 Layers. & \\
\cline { 2 - 5 } 10 & 17 & 18 & 13 & 14 & 4.6 \\
50 & 19 & 20 & 15 & 16 & 4.7 \\
100 & 21 & 22 & 17 & 18 & 4.3 \\
500 & 23 & 24 & 19 & 20 & 4.9 \\
\hline
\end{tabular}

Powder Spray yelding Process.

\begin{tabular}{|c|c|c|c|c|c|}
\hline \multirow[t]{2}{*}{$\begin{array}{l}\text { Number } \\
\text { of } \\
\text { Scratches }\end{array}$} & \multicolumn{2}{|c|}{$\begin{array}{l}\text { Average ivear } \\
\text { Volumes } \\
\text { Table Numbers } \\
\text {. }\end{array}$} & \multicolumn{2}{|c|}{$\begin{array}{l}\text { Detailed Results } \\
\text { Appendix } 2 \\
\text { Table Iumbers }\end{array}$} & $\begin{array}{c}\text { Graphical } \\
\text { Summarisation } \\
\text { Figure Number }\end{array}$ \\
\hline & 1 Layer & 2 Layers & I Layer & 2 Layers & \\
\hline 10 & 25 & 26 & 21 & 22 & 4.10 \\
\hline 50 & 27 & 28 & 23 & 24 & 4.11 \\
\hline 100 & 29 & 30 & 25 & 26 & $4 \cdot 12$ \\
\hline 500 & 31 & 32 & 27 & 28 & 4.13 \\
\hline
\end{tabular}

Oxy-acetylene Welding Process 


\begin{tabular}{|c|c|c|c|c|c|}
\hline \multirow{2}{*}{$\begin{array}{c}\text { ingoer } \\
\text { Or } \\
\text { scratches }\end{array}$} & \multicolumn{2}{|c|}{$\begin{array}{c}\text { Average } y \in a r \\
\text { Vollimes } \\
\text { Tabie Humbers }\end{array}$} & \multicolumn{2}{|c|}{$\begin{array}{l}\text { Detailed Results } \\
\text { Apoerdix } \\
\text { Pable funders }\end{array}$} & \multirow{2}{*}{$\begin{array}{l}\text { Graphical } \\
\text { Summarisation } \\
\text { Figure Number }\end{array}$} \\
\hline & I Layer & 2 Layers & I Layer & 2 Layers & \\
\hline 10 & 33 & 34 & 29 & 30 & 4.14 \\
\hline 50 & 35 & 36 & 31 & 32 & 4.15 \\
\hline 100 & 37 & 38 & 33 & 34 & 4.16 \\
\hline 500 & 39 & 40 & 35 & 36 & 4.17 \\
\hline
\end{tabular}

Tungsten Inert Gas Wieldine Process

\subsubsection{Comparative gesuits Preseritation}

In orcier to provide a direct comparison between the wear test results for each process according to the number ol scratches and the number of deposited layers the following figures were prepared:

\begin{tabular}{|c|c|l|}
\hline $\begin{array}{l}\text { ivimisr cf } \\
\text { Scratches }\end{array}$ & Number of Denosited Layers & $\begin{array}{l}\text { Figure } \\
\text { Number }\end{array}$ \\
\hline \multirow{2}{*}{10} & 1 Layer & $4 \cdot 18$ \\
& 2 Layers & 4.19 \\
\hline 50 & I Layer & 4.20 \\
& 2 Layers & 4.21 \\
\hline 100 & I Layer & 4.22 \\
& 2 Layers & 4.23 \\
\hline 500 & I Layer & 4.24 \\
\hline
\end{tabular}

4.2 Surface Haraness Test Results

In the absence of a Brinell Hardness Testing macrine a Rockwell machine, with a ball indentor, was used to measure the hardness of the grey cast iron substrate material. For reasons of standardisation this test was also used to measure the surface hardness of the nardiaced coatings, although the C scale was necessary for these harder materials. To enable a comparison 
to be made bet:keen the sur ïace hardness and other hardness tes.ts the former were converied into equivalent Vickers tardness Numbers.

The results of the surface hardness tests by process are shown in Tables 41 to 44 .

Table 41 : Thermal Spraying

Table 42 : Powder suray ijelding

Table 43 : Oxy-acetylene ilelding

Table 44 : Tungsten Inert Gas "Ielding

4.3 Macro Hardiness Profile Results

Ideally for comparison purposes the hardness measurements should have been made at similar distances from the startinf point for each of tine specimens. However, this proved to be impracticable as some difficulty was encountered in seting the testinf machine. The measurements were taken as near equal as practicable for comparability. As each test was repeated five times the data has been processed for ease of analysis. The average values of hardiness for distance from the starting point are presented in separate tables for the one layer and two layer tesis with both sets of tests being̈ shown together graphically in the same figure. The detailed results are presented in taoular form in Appendix 3.

The relevant Table and Figure numbers are presented below:

\begin{tabular}{|c|c|c|c|c|c|}
\hline Process & \multicolumn{2}{|c|}{$\begin{array}{c}\text { Uacro Hardiness } \\
\text { Profiles } \\
\text { Average Values } \\
\text { Table Numbers }\end{array}$} & \multicolumn{2}{|c|}{$\begin{array}{l}\text { Detailed Results } \\
\text { Appendix } 5 \\
\text { Table Numbers }\end{array}$} & $\begin{array}{c}\text { Graphical } \\
\text { Summarisation } \\
\text { Figure Number }\end{array}$ \\
\hline & I Layer & ¿ Layers & I Layer & ¿ Layers & \\
\hline $\begin{array}{l}\text { Thermal } \\
\text { Spraying }\end{array}$ & 45 & 46 & 37 & 38 & 4.26 \\
\hline $\begin{array}{c}\text { Powder spray } \\
\text { :felding }\end{array}$ & 47 & 48 & 39 & 40 & $4 \cdot \dot{2} 7$ \\
\hline $\begin{array}{c}\text { Oxy-acetylene } \\
\text { yelding }\end{array}$ & 49 & 50 & 41 & 42 & 4.28 \\
\hline T.I.G. & 51 & 52 & 43 & 44 & 4.29 \\
\hline
\end{tabular}


Hardaced coatings are extremeIy hard but this hardness may be adversely affected by the alloy being diluted by the substrate. To provide an indication of the presence and degree of dilution Electron Probe Microanalysis was conducted to estabiish the percentage of the elements $\mathrm{Ni}, \mathrm{Cr}, \mathrm{Si}$ and $\mathrm{Fe}$ across the interface between the deposit and the substrate.

The aporoximate percentages of these elements, for both the one and two lajer deposits, are snown respectively in Tables 53, 54, 55 and 56. More details or the EPMA readings are given in A:pendix 4 .

\subsection{0otical iricroscopy}

Spraying and welding processes frovide deposition methods which differ significantly, in particular with respest to the heat inout and cooling rate experienced by the substrate. This can affect the structure of the alloy deposited and the integrity of the bond between the alioy and the substrate. This latter possibility is of particular concern in the case of cast iron because graphite may be removed. Optical microscopy was used to assess these factors and the results obtained are presented in the form of photonicrographs.

For eacn process five photonicrographs are presented. In each case these have been prepared as follows:

(a) Etched with Hurakani's reagent to show the carbide particies.

(b) Etched with mixed acids to snow the boride particles.

(c) Etched with both Murakami's reagent and mixed acids - to show carbides, borides and alloy matrix

(d) Unetcined to identify the graphite in relation to the coating, bond and substrate regions. 
(e) Etched with both Murakam's reagent and mixed acids to show the integrity of the bond.

\begin{tabular}{|l|c|c|c|c|c|}
\hline \multirow{2}{*}{ Process. } & \multicolumn{5}{|c|}{ Preparation Procedure } \\
\cline { 2 - 6 } & (a) & (b) & (c) & (d) & (e) \\
\hline $\begin{array}{c}\text { Thermal } \\
\text { Spraying }\end{array}$ & $4.1 \mathrm{a}$ & $4.1 \mathrm{~b}$ & 4.2 & 4.3 & 4.4 \\
\hline $\begin{array}{c}\text { Powder Spray } \\
\text { Velding }\end{array}$ & $4.5 \mathrm{a}$ & 4.50 & 4.6 & 4.7 & 4.8 \\
\hline $\begin{array}{c}\text { Oxy-acetylene } \\
\text { :ielding }\end{array}$ & $4.9 \mathrm{a}$ & 4.90 & 4.10 & 4.11 & 4.12 \\
\hline T.I.G. & $4.15 \mathrm{a}$ & 4.130 & 4.14 & 4.15 & 4.16 \\
\hline
\end{tabular}


Table 5

\begin{tabular}{|c|c|cc|}
\hline Load Kgs & Test No & \multicolumn{2}{|c|}{$\begin{array}{c}\text { Average } \\
\text { Wear Volume m m}\end{array}$} \\
\hline \multirow{4}{*}{2.5} & 1 & 1.745 & \\
& 2. & 1.705 & \\
& 3 & 2.494 & 1.915 \\
& 4 & 1.586 & \\
& 5 & 2.042 & \\
\hline & 1 & 2.790 & \\
& 2 & 3.130 & \\
5 & 3 & 3.695 & \\
& 4 & 3.135 & 2.210 \\
& 5 & 3.295 & \\
& 1 & 4.166 & \\
& 2 & 5.880 \\
10 & 3 & 5.959 & 5.452 \\
& 4 & 5.300 \\
.. & 5 & 5.959 \\
\hline
\end{tabular}

Grey Cast Iron 10 Scratches

Table 6

\begin{tabular}{|c|c|cc|}
\hline Load Kgs & Test No & \multicolumn{2}{|c|}{$\begin{array}{c}\text { Average } \\
\text { Wear Volume mm } 3\end{array}$} \\
\hline \multirow{4}{*}{2.5} & 1 & 1.935 & \\
& 2 & 3.295 & \\
& 3 & 3.695 & 3.050 \\
& 4 & 2.768 & \\
& 5 & 3.560 & \\
\hline & 1 & 4.137 & \\
& 2 & 5.959 & \\
5 & 3 & 6.321 & 5.211 \\
& 4 & 4.367 & \\
& 5 & 4.771 & \\
& 1 & 7.846 & \\
& 2 & 3.529 \\
10 & 3 & 3.857 \\
& 4 & 0.318 & 2.926 \\
& 5 & 8.081 \\
\hline
\end{tabular}




\begin{tabular}{|c|c|ll|}
\hline Load Kgs & Test No & \multicolumn{2}{|c|}{$\begin{array}{c}\text { Average } \\
\text { Wear Volume m m}\end{array}$} \\
\hline & 1 & 3.295 & \\
& 2 & 3.695 & \\
2.5 & 3 & 4.391 & 4.360 \\
& 4 & 4.542 & \\
& 5 & 5.880 & \\
\hline & 1 & 5.481 & \\
& 2 & 5.959 & \\
5 & 3 & 6.318 & 6.301 \\
& 4 & 6.749 & \\
& 5 & 6.999 & \\
& 1 & 8.698 & \\
& 2 & 9.529 & \\
10 & 3 & 9.634 & 2.450 \\
& 4 & 9.529 & \\
& 5 & 9.361 & \\
\hline
\end{tabular}

\section{Grey Cast Iron 100 Saratches}

Table 8

\begin{tabular}{|c|c|cc|}
\hline Load Kgs & Test No & \multicolumn{2}{|c|}{$\begin{array}{c}\text { Average } \\
\text { Wear Volume mm }\end{array}$} \\
\hline \multirow{4}{*}{2.5} & 1 & 5.880 & \\
& 2 & 5.959 & \\
& 3 & 6.321 & 6.132 \\
& 4 & 6.318 & $\underline{ }$ \\
& 5 & 6.185 & \\
\hline & 1 & 8.571 & \\
& 2 & 9.529 & \\
5 & 3 & 8.529 & \\
& 4 & 9.130 \\
& 5 & 9.384 & \\
& 1 & 16.638 & \\
& 2 & 15.510 & \\
& 3 & 16.638 & 15.993 \\
& 4 & 14.049 & \\
& 5 & 17.131 \\
\hline
\end{tabular}




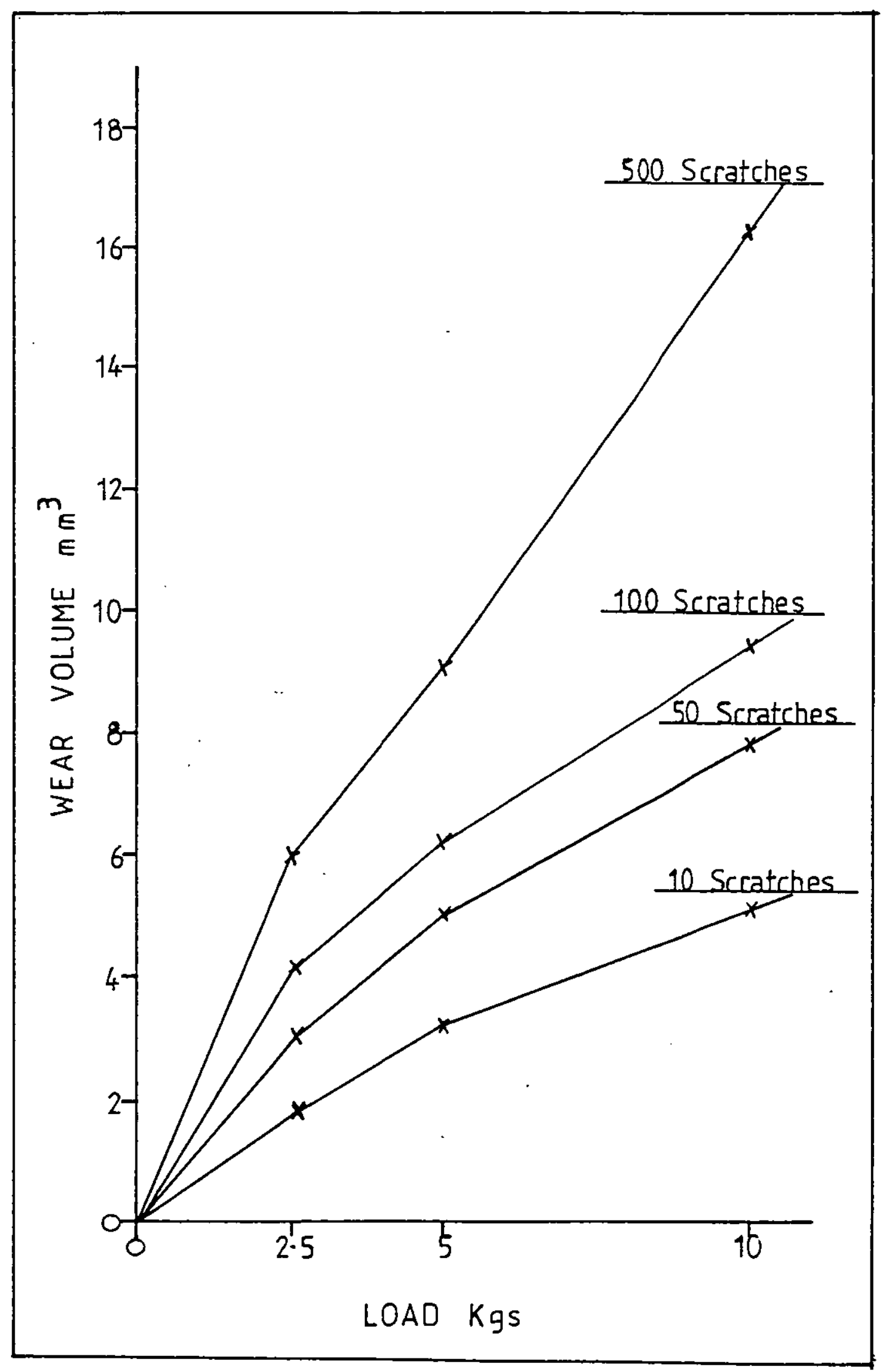

FIG 4.1 Wear Volume Vs Load

Grey Cast Iron 


\begin{tabular}{|c|c|cc|}
\hline Load Kgs & Test No & \multicolumn{2}{|c|}{$\begin{array}{c}\text { Average } \\
\text { Wear Volume mo }\end{array}$} \\
\hline \multirow{4}{*}{2.5} & 1 & 0.073 & \\
& 2 & 0.108 & \\
& 3 & 0.184 & 0.111 \\
& 4 & 0.068 & \\
& 5 & 0.122 & \\
\hline & 1 & 0.249 & \\
& 2 & 0.263 & \\
5 & 3 & 0.263 & 0.264 \\
& 4 & 0.209 & \\
& 5 & 0.340 & \\
& 1 & 0.402 & \\
& 2 & 0.385 & \\
10 & 3 & 0.438 & 0.395 \\
& 4 & 0.329 & \\
& 5 & 0.422 & \\
\hline
\end{tabular}

Thermal Soraying 1 Layer Deposit 10 Scratches

Table 10

\begin{tabular}{|c|c|ll|}
\hline Load Kgs & Test No & \multicolumn{2}{|c|}{$\begin{array}{c}\text { Average } \\
\text { Wear Volume m }{ }^{3}\end{array}$} \\
\hline \multirow{4}{*}{2.5} & 1 & 0.064 & \\
& 2 & 0.068 & \\
& 3 & ZERO & 0.040 \\
& 4 & 0.068 & \\
& 5 & ZERO & \\
\hline & 1 & 0.209 & \\
& 2 & 0.151 & \\
5 & 3 & 0.027 & 0.137 \\
& 4 & 0.235 & \\
& 5 & 0.064 & \\
\hline \multirow{4}{*}{10} & 1 & 0.306 & \\
& 2 & 0.337 & \\
& 3 & 0.300 & 0.315 \\
& 4 & 0.329 & \\
& 5 & 0.306 & \\
\hline
\end{tabular}




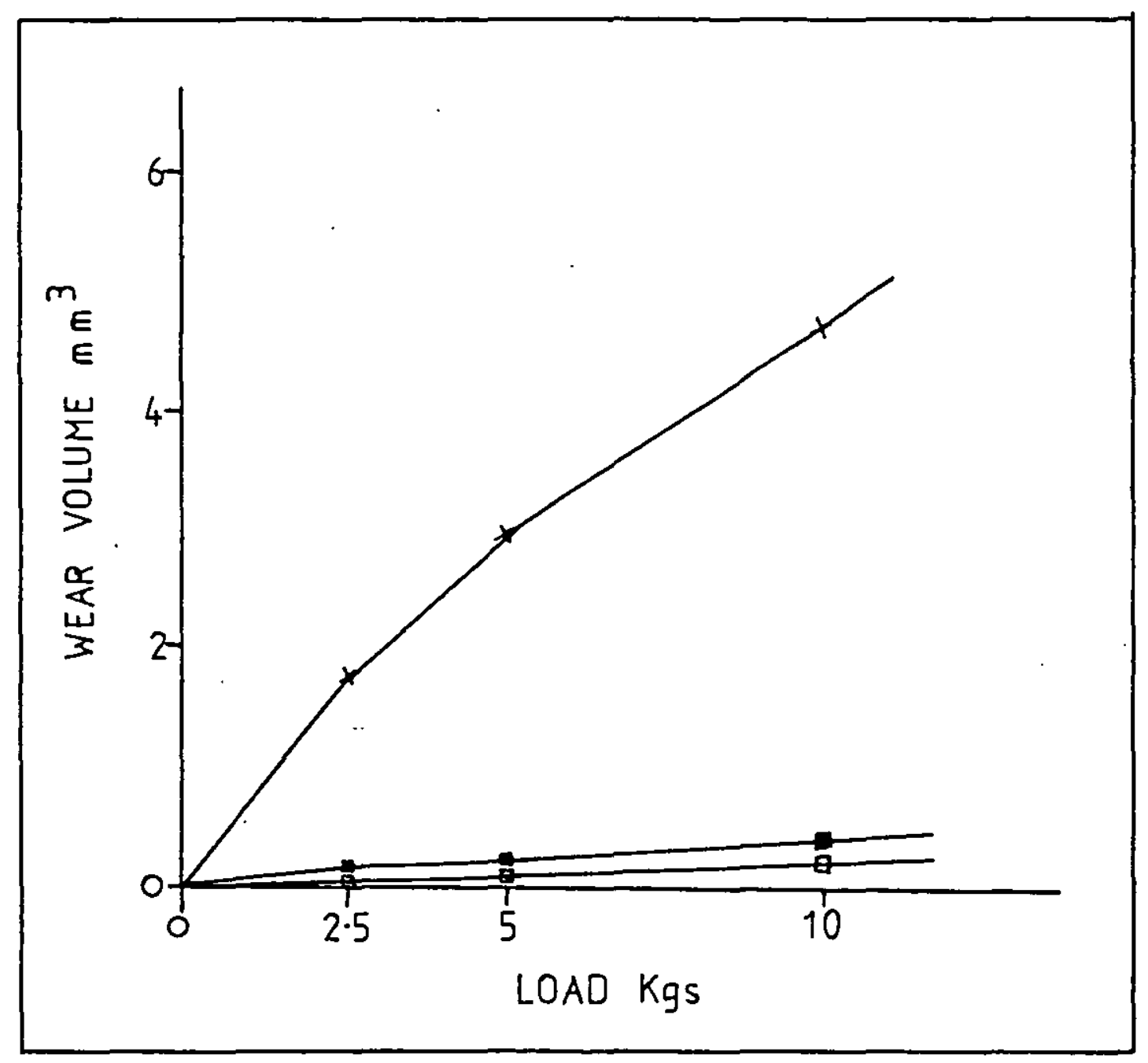

EIG 4.2 Wear Volume Vs Load. THERMAL SPRAYING 10 Scratches

$$
\begin{aligned}
& x=\text { Cast Iron } \\
& \text { a }=1 \text { Layer Deposit } \\
& \square=2 \text { Layer Deposits }
\end{aligned}
$$

71. 


\begin{tabular}{|c|c|ll|}
\hline Load Kgs & Test No & \multicolumn{2}{|c|}{$\begin{array}{c}\text { Average } \\
\text { Wear Volume mm }\end{array}$} \\
\hline \multirow{4}{*}{2.5} & 1 & 0.340 & \\
& 2 & 0.613 & \\
& 3 & 0.389 & 0.459 \\
& 4 & 0.586 & $\underline{ }$ \\
& 5 & 0.368 & \\
\hline & 1 & 0.586 & \\
& 2 & 0.370 & \\
5 & 3 & 0.522 & 0.655 \\
& 4 & 0.716 & \\
& 5 & 0.582 & \\
& 1 & 0.959 & \\
& 2 & 1.283 & \\
10 & 3 & 0.925 & 1.039 \\
& 4 & 1.099 & \\
& 5 & 0.931 \\
\hline
\end{tabular}

Thermal Spraying 1 Layer Deposit 50 Scratches

Table 12

\begin{tabular}{|c|c|c|c|}
\hline Load Kgs & Test No & $\begin{array}{l}\text { Al } \\
\text { Wear }\end{array}$ & $\begin{array}{l}\text { rage } \\
\text { lume } \mathrm{mm}^{3}\end{array}$ \\
\hline \multirow{5}{*}{$2 \cdot 5$} & 1 & 0.384 & \multirow{5}{*}{$\underline{0.359}$} \\
\hline & 2 & 0.291 & \\
\hline & 3 & 0.353 & \\
\hline & 4 & 0.384 & \\
\hline & 5 & 0.385 & \\
\hline \multirow{5}{*}{5} & 1 & 0.582 & \multirow{5}{*}{$0.57 ?$} \\
\hline & 2 & 0.611 & \\
\hline & 3 & 0.583 & \\
\hline & 4 & 0.565 & \\
\hline & 5 & 0.545 & \\
\hline \multirow{4}{*}{10} & 1 & 0.819 & \multirow{4}{*}{$\underline{0.826}$} \\
\hline & 2 & 0.771 & \\
\hline & 3 & 0.399 & \\
\hline & $\begin{array}{l}4 \\
5\end{array}$ & $\begin{array}{l}0.911 \\
0.730\end{array}$ & \\
\hline
\end{tabular}

Thermal Spraying 2 Layer Deposits 50 Scratches 


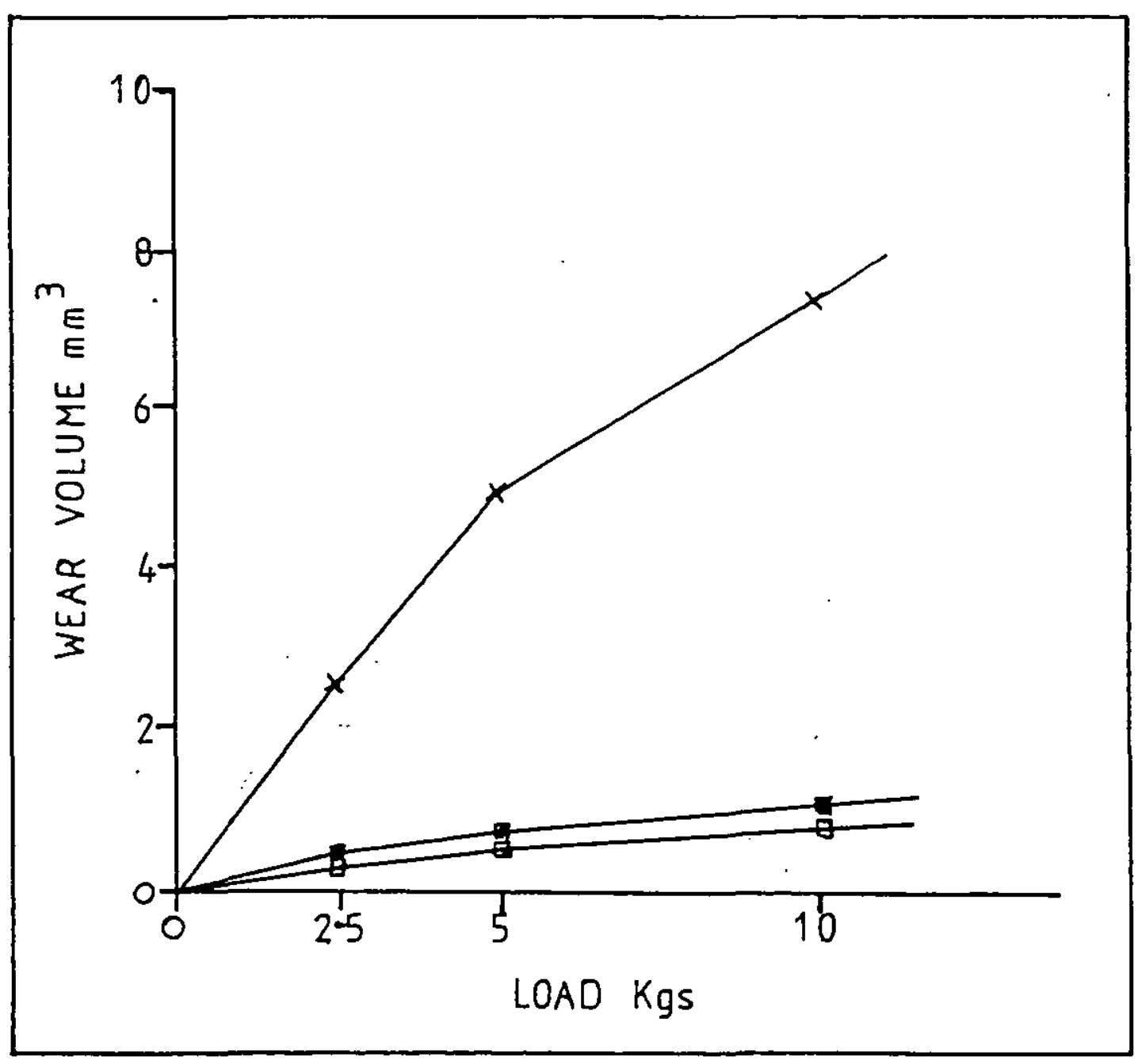

EIG 4.3 Wear Volume Vs Load THERMAL SPRAYING 50 Scratches

$x=$ Cast Iron "

I $=1$ Layer Deposit

$\square=2$ Layer Deposits 


\begin{tabular}{|c|c|ll|}
\hline Load Kgs & Test No & \multicolumn{2}{|c|}{ Average } \\
Wear & Volume m 3 \\
\hline \multirow{4}{*}{2.5} & 1 & 0.630 & \\
& 2 & 0.419 & \\
& 3 & 0.565 & 0.407 \\
& 4 & 0.430 & \\
& 5 & 0.384 & \\
\hline \multirow{5}{*}{5} & 1 & 1.020 & \\
& 2 & 0.730 & \\
& 3 & 0.373 & 0.817 \\
& 4 & 0.821 & \\
& 5 & 0.645 & \\
& 1 & 1.116 & \\
& 2 & 0.911 & \\
& 3 & 1.293 & 1.104 \\
& 4 & 1.193 & \\
& 5 & 1.008 & \\
\hline
\end{tabular}

Thermal Spraying 1 Layer Deposit 100 Scratches Table 14

\begin{tabular}{|c|c|cc|}
\hline Load Kgs & Test No & \multicolumn{2}{|c|}{$\begin{array}{c}\text { Average } \\
\text { Wear Volume m }\end{array}$} \\
\hline \multirow{4}{*}{2.5} & 1 & 0.340 & \\
& 2 & 0.492 & \\
& 3 & 0.155 & 0.372 \\
& 4 & 0.384 & \\
& 5 & 0.492 & \\
\hline & 1 & 0.673 & \\
& 2 & 0.863 & \\
5 & 3 & 0.340 & 0.652 \\
& 4 & 0.565 & \\
& 5 & 0.819 & \\
& 1 & 0.873 & \\
& 2 & 1.026 & \\
10 & 3 & 0.794 \\
& 4 & 0.873 & 0.966 \\
& 5 & 1.267 \\
\hline
\end{tabular}

Thermal Spraying 2 Layer Deposits 100 Scratches 


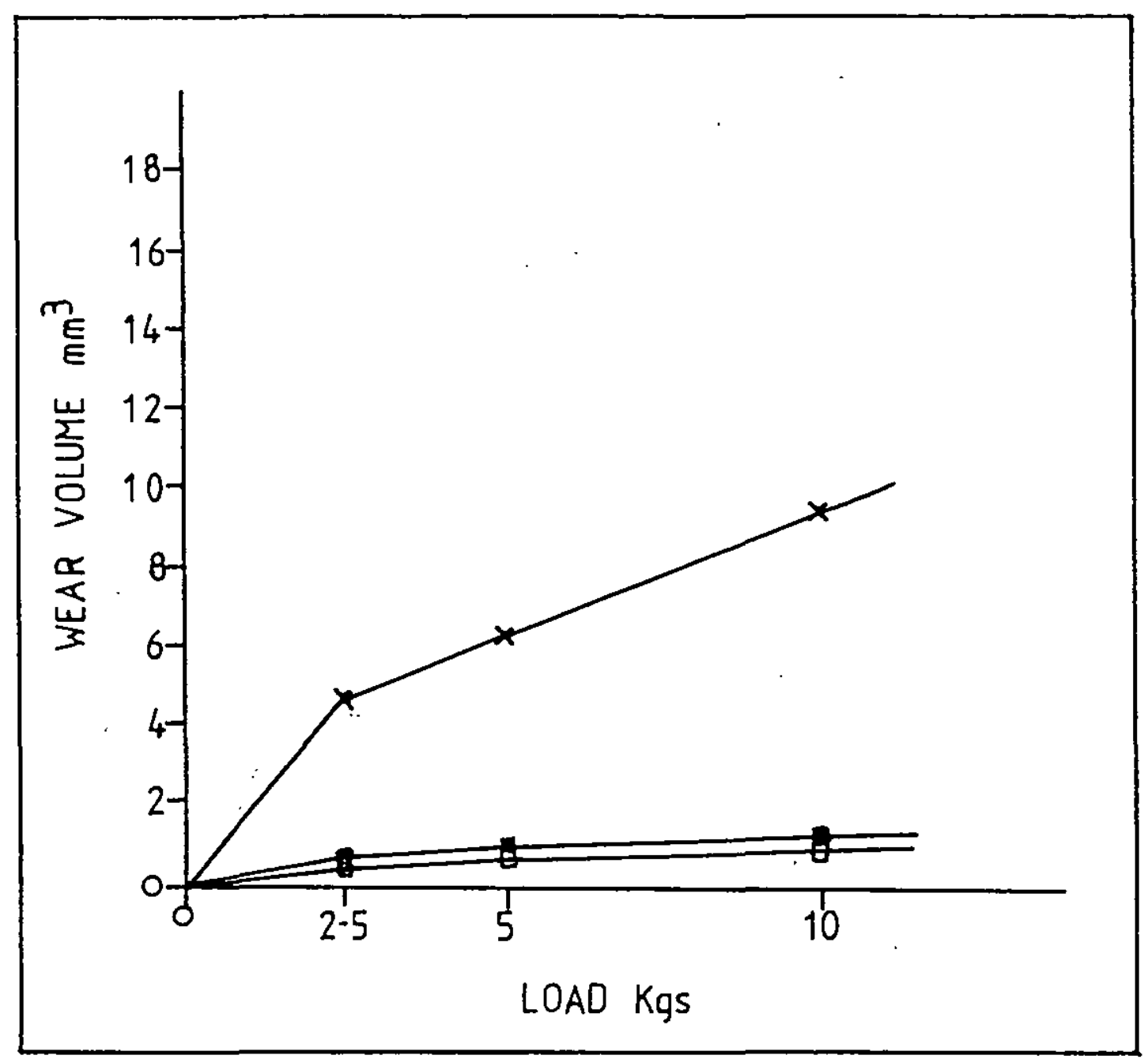

FIG 4.4 Wear Volume Vs Load THERMAL SPRAYING 100 Scratches

$$
\begin{aligned}
& x=\text { Cast Iron } \\
& \mathbf{a}=1 \text { Layer Deposit } \\
& \square=2 \text { Layer Deposits }
\end{aligned}
$$




\begin{tabular}{|c|c|c|c|}
\hline Load Kgs & Test No & $\begin{array}{r}\text { AV } \\
\text { Wear }\end{array}$ & lume $\mathrm{mm}^{3}$ \\
\hline \multirow{5}{*}{$2 \cdot 5$} & 1 & 0.923 & \multirow{5}{*}{$I .591$} \\
\hline & 2 & 1.972 & \\
\hline & 3 & 1.387 & \\
\hline & 4 & 1.623 & \\
\hline & 5 & 1.551 & \\
\hline \multirow{5}{*}{5} & 1 & 2.037 & \multirow{5}{*}{$3.64 ?$} \\
\hline & 2 & 3.254 & \\
\hline & 3 & 2.968 & \\
\hline & 4 & $\bar{c} .582$ & \\
\hline & 5 & 2.497 & \\
\hline \multirow{5}{*}{10} & 1 & 2.903 & \multirow{5}{*}{3.758} \\
\hline & 2 & 4.720 & \\
\hline & 3 & 3.763 & \\
\hline & 4 & 3.831 & \\
\hline & 5 & 3.575 & \\
\hline
\end{tabular}

Thermal Spraying 1 Layer Deposit 500 Scratches

Table 16

\begin{tabular}{|c|c|c|c|}
\hline Load Kgs & Test No & $\begin{array}{r}A V \\
\text { Wear V }\end{array}$ & $\begin{array}{l}\text { age } \\
\text { lume } \mathrm{m}^{3}\end{array}$ \\
\hline \multirow{4}{*}{$2 \cdot 5$} & 1 & 0.988 & \multirow{4}{*}{1.121} \\
\hline & 2 & 0.728 & \\
\hline & 3 & 1.387 & \\
\hline & $\begin{array}{l}4 \\
5\end{array}$ & $\begin{array}{l}1.382 \\
0.620\end{array}$ & \\
\hline \multirow{5}{*}{5} & 1 & 2.042 & \multirow{5}{*}{1.870} \\
\hline & 2 & 1.586 & \\
\hline & 3 & 2.499 & \\
\hline & 4 & 2.182 & \\
\hline & 5 & 1.043 & \\
\hline \multirow{4}{*}{10} & 1 & 2.768 & \multirow{4}{*}{2.360} \\
\hline & 2 & 3.560 & \\
\hline & 3 & 3.135 & \\
\hline & $\begin{array}{l}4 \\
5\end{array}$ & $\begin{array}{l}2.798 \\
2.080\end{array}$ & \\
\hline
\end{tabular}

Thermal Spraying 2 Layer Deposits 500 Scratches 


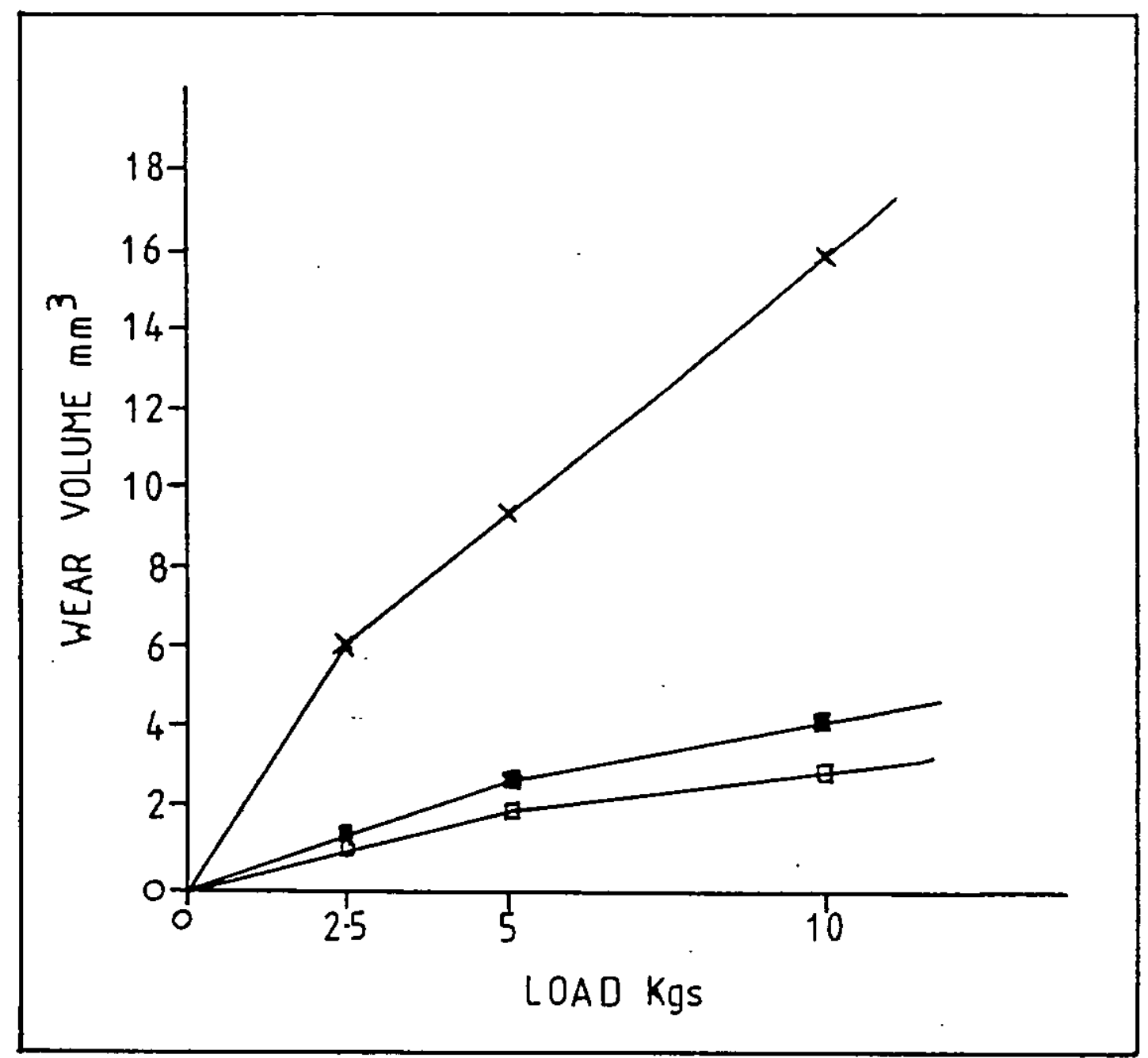

FIG 4.5 Wear Volume Vs Load THERMAL SPRAYING 500 Scratches

$x=$ Cast Iron:

- $=1$ Layer Deposit

$\square=2$ Layer Deposits 


\begin{tabular}{|c|c|ll|}
\hline Load Kgs & Test No & \multicolumn{2}{|c|}{$\begin{array}{c}\text { Average } \\
\text { Wear }\end{array}$} \\
\hline \multirow{4}{*}{2.5} & 1 & 0.100 & \\
& 2 & $0.27 y$ & \\
& 3 & 0.134 & 0.157 \\
& 4 & 0.108 & \\
& 5 & 0.108 & \\
\hline \multirow{4}{*}{5} & 1 & 0.263 & \\
& 2 & 0.459 & \\
& 3 & 0.263 & 0.296 \\
& 4 & 0.235 & \\
& 5 & 0.263 & \\
& 5 & 0.459 & \\
& 1 & 0.874 & \\
10 & 2 & 0.608 & 0.568 \\
& 3 & 0.384 & \\
& 4 & 0.438 \\
\hline
\end{tabular}

Pawder Spray Welding 1 Layer Deposit 10 Scratches

Table 18

\begin{tabular}{|c|c|ll|}
\hline Load Kgs & Test No & \multicolumn{2}{|c|}{$\begin{array}{c}\text { Average } \\
\text { Wear Volume m m }\end{array}$} \\
\hline \multirow{4}{*}{2.5} & 1 & ZeRO & \\
& 2 & 0.054 & \\
& 3 & 0.063 & 0.038 \\
& 4 & 0.060 & \\
& 5 & ZeRO & \\
\hline \multirow{4}{*}{5} & 1 & 0.085 & \\
& 2 & 0.151 & \\
& 3 & 0.116 & 0.146 \\
& 4 & 0.209 & \\
& 5 & 0.172 & \\
& 1 & 0.136 & \\
& 2 & 0.330 \\
10 & 3 & 0.256 & 0.273 \\
& 4 & 0.337 \\
& 5 & 0.306 \\
\hline
\end{tabular}

Pöwder Spray Weiding 2 Layer Deposits 10 Scratches 


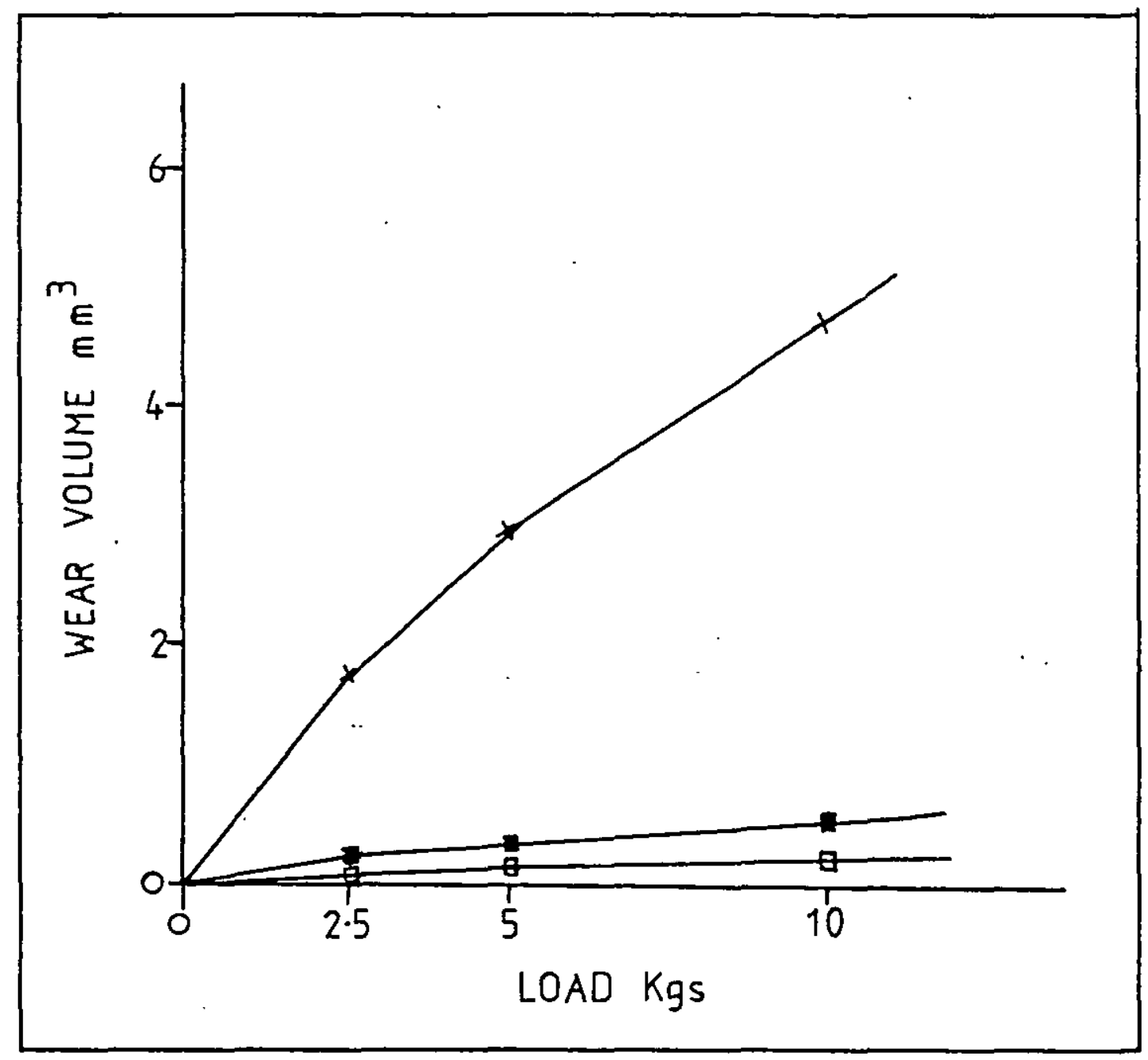

FIG 4.6 Wear Volume Vs Load.

POWDER SPRAYING 10 Scratches

$x=$ Cast Iron

- $=1$ Layer Deposit

$\square=2$ Layer Deposits 


\begin{tabular}{|c|c|c|c|}
\hline Load Kgs & Test No & $\begin{array}{r}\text { Av } \\
\text { Wear }\end{array}$ & lume $\mathrm{mm}^{3}$ \\
\hline \multirow{5}{*}{$2 \cdot 5$} & 1 & $0.30 \mathrm{y}$ & \multirow{5}{*}{0.321} \\
\hline & 2 & 0.235 & \\
\hline & 3 & 0.279 & \\
\hline & 4 & 0.3034 & \\
\hline & 5 & 0.321 & \\
\hline \multirow{5}{*}{5} & 1 & 0.622 & \multirow{5}{*}{0.579} \\
\hline & 2 & 0.419 & \\
\hline & 3 & 0.459 & \\
\hline & 4 & 0.733 & \\
\hline & 5 & 0.663 & \\
\hline \multirow{5}{*}{10} & 1 & 1.199 & \multirow{5}{*}{1.065} \\
\hline & 2 & 0.876 & \\
\hline & 3 & 0.874 & \\
\hline & 4 & 1.276 & \\
\hline & 5 & 1.100 & \\
\hline
\end{tabular}

Powder Spray Welding 1 Layer Deposit 50 Scratches

Table 20

\begin{tabular}{|c|c|c|c|}
\hline Load Kgs & Test No & $\begin{array}{r}\text { Av } \\
\text { Wear }\end{array}$ & ume $\mathrm{mm}^{3}$ \\
\hline \multirow{5}{*}{$2 \cdot 5$} & 1 & 0.224 & \multirow{5}{*}{0.310} \\
\hline & 2 & 0.353 & \\
\hline & 3 & 0.249 & \\
\hline & 4 & 0.308 & \\
\hline & 5 & 0.419 & \\
\hline \multirow{5}{*}{5} & 1 & 0.534 & \multirow{5}{*}{0.575} \\
\hline & 2 & 0.583 & \\
\hline & 3 & 0.545 & \\
\hline & 4 & 0.583 & \\
\hline & 5 & 0.630 & \\
\hline \multirow{4}{*}{10} & 1 & 0.854 & \multirow{4}{*}{0.881} \\
\hline & 2 & 0.847 & \\
\hline & 3 & 0.321 & \\
\hline & $\begin{array}{l}4 \\
5\end{array}$ & $\begin{array}{l}0.390 \\
0.997\end{array}$ & \\
\hline
\end{tabular}

Pöwder Spray Welding 2 Layer Deposits. 50 Scratches 


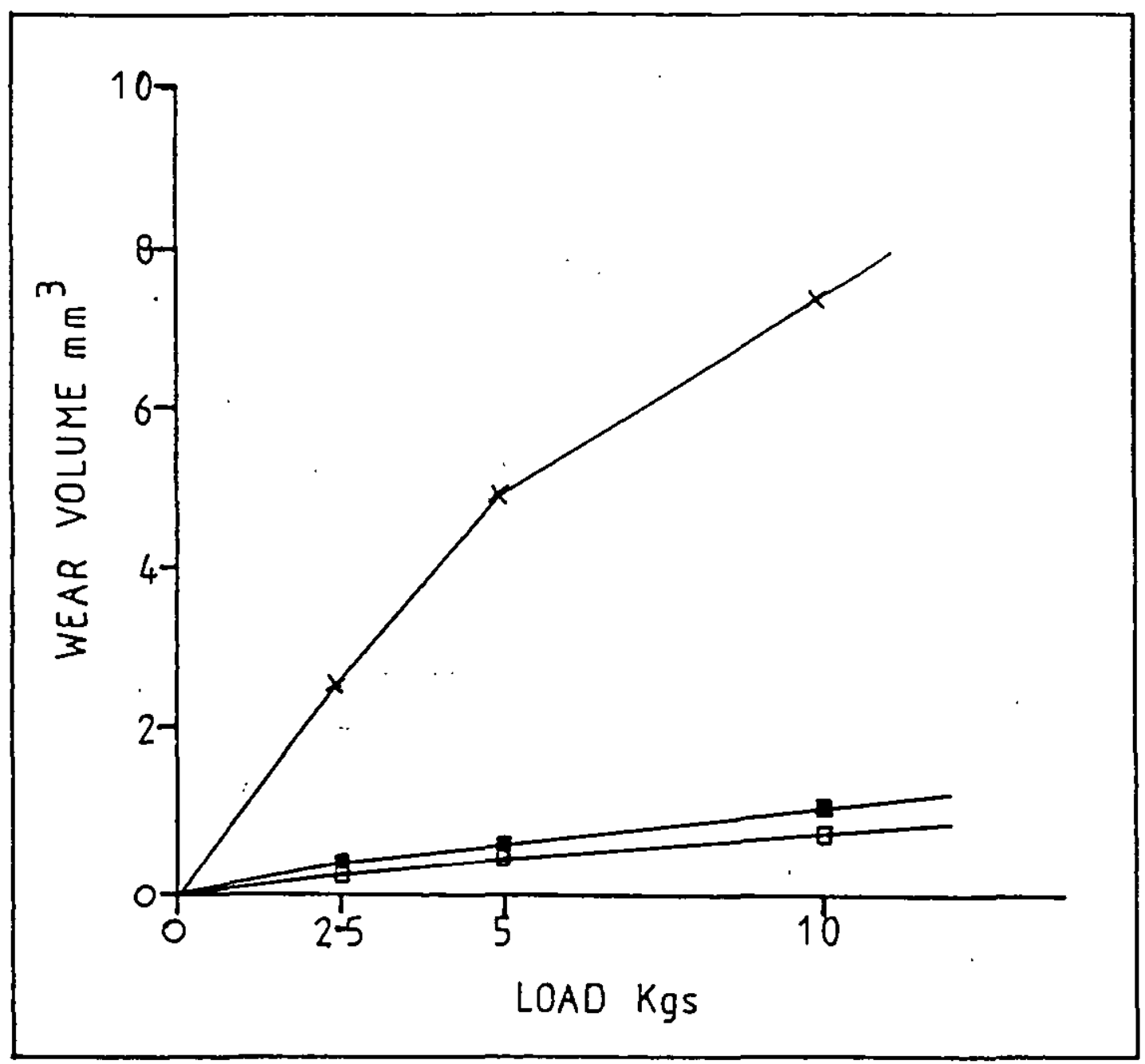

FIG 4.7 Wear Volume Vs Load
POWDER SPRAYING 50 Scratches

$x=$ Cast Iron .

m $=1$ Layer Deposit

$\square=2$ Layer Deposits 
Table 21

\begin{tabular}{|c|c|ll|}
\hline Load Kgs & Test No & \multicolumn{2}{|c|}{$\begin{array}{c}\text { Average } \\
\text { Wear Volume mm }{ }^{3}\end{array}$} \\
\hline \multirow{4}{*}{2.5} & 1 & 0.603 & \\
& 2 & 0.404 & \\
& 3 & 0.249 & 0.410 \\
& 4 & 0.504 & $\underline{ }$ \\
& 5 & 0.285 & \\
\hline & 1 & 0.377 & \\
& 2 & 0.608 & \\
5 & 3 & 0.395 & 0.627 \\
& 4 & 0.917 & \\
& 5 & 0.340 & \\
& 1 & 1.257 & \\
& 2 & 1.055 & \\
10 & 3 & 0.964 & 1.064 \\
& 4 & 1.086 & \\
& 5 & 0.959 \\
\hline
\end{tabular}

Powder Spray Welding 1 Layer Deposit 100 Scratches Table 22

\begin{tabular}{|c|c|cc|}
\hline Load Kgs & Test No & \multicolumn{2}{|c|}{$\begin{array}{c}\text { Average } \\
\text { Wear Volume m m }\end{array}$} \\
\hline \multirow{4}{*}{2.5} & 1 & 0.492 & \\
& 2 & 0.249 & \\
& 3 & 0.155 & 0.305 \\
& 4 & 0.384 & \\
& 5 & 0.249 & \\
\hline & 1 & 0.623 & \\
& 2 & 0.532 & \\
5 & 3 & 0.337 & \\
& 4 & 0.630 & 0.559 \\
& 5 & 0.624 & \\
\hline \multirow{4}{*}{10} & 1 & 1.099 & \\
& 2 & 0.319 & \\
& 3 & 0.720 & 0.955 \\
& 4 & 1.220 & \\
\hline
\end{tabular}

Pöwder Spray Welding 2 Layer Deposits 100 Scratches 


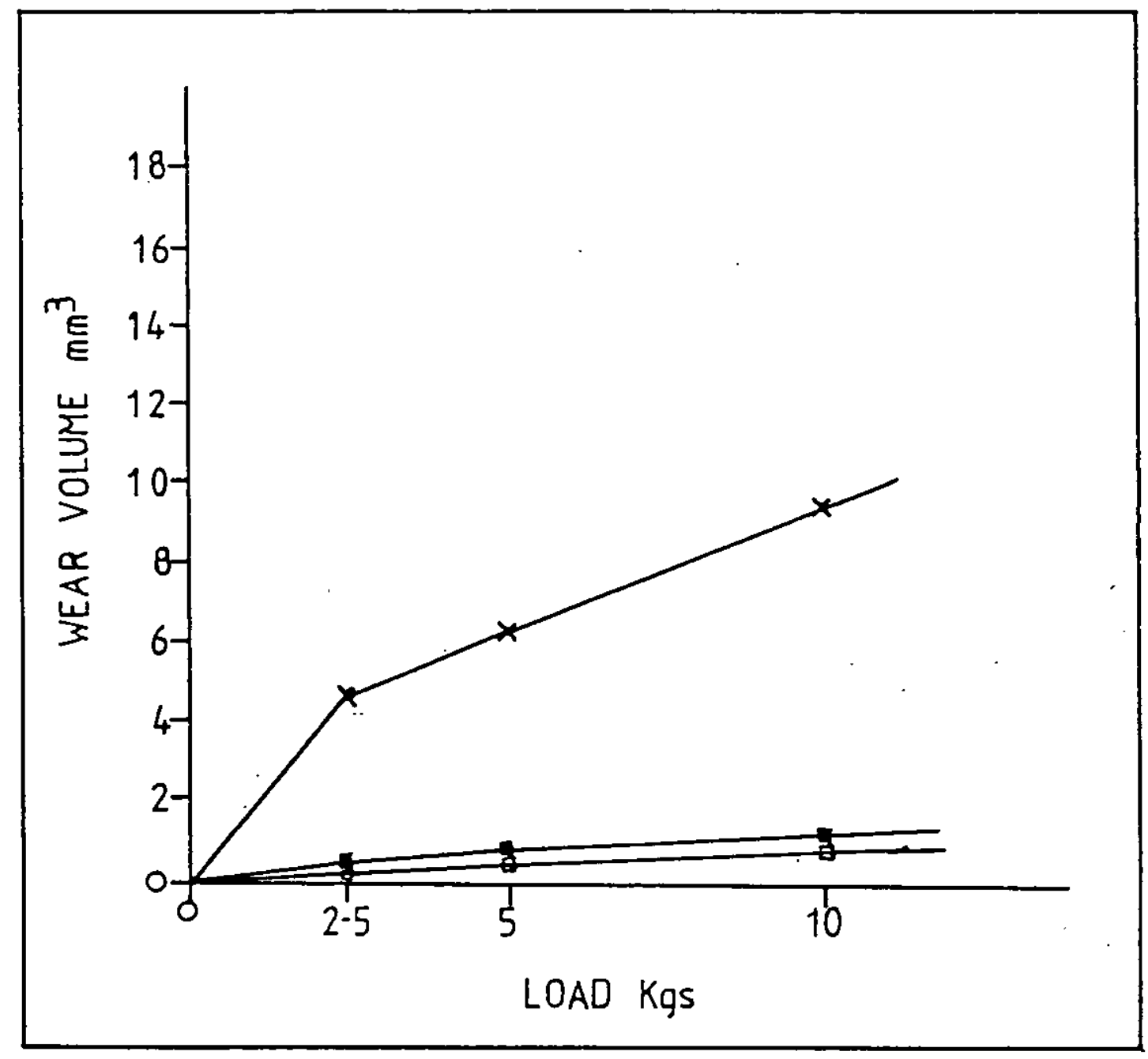

FIG 4.8 Wear Volume Vs Load POWDER SPRAYING 100 Scratches

$x=$ Cast Iron

$\boldsymbol{m}=1$ Layer Deposit

$\square=2$ Layer Deposits 


\begin{tabular}{|c|c|c|c|}
\hline Load Kgs & Test No & Wear & $\begin{array}{l}\text { rage } \\
\text { olume } \mathrm{mm}^{3}\end{array}$ \\
\hline \multirow{5}{*}{$2 \cdot 5$} & 1 & 1.296 & \multirow{5}{*}{$\underline{1.452}$} \\
\hline & 2 & 1.573 & \\
\hline & 3 & 1.554 & \\
\hline & 4 & 1.342 & \\
\hline & 5 & 1.723 & \\
\hline \multirow{5}{*}{5} & 1 & 2.260 & \multirow{5}{*}{2.090} \\
\hline & 2 & 2.302 & \\
\hline & 3 & 1.496 & \\
\hline & 4 & 1.387 & \\
\hline & 5 & 2.499 & \\
\hline \multirow{5}{*}{10} & 1 & 3.655 & \multirow{5}{*}{3.439} \\
\hline & 2 & 3.653 & \\
\hline & 3 & 2.260 & \\
\hline & 4 & 3.154 & \\
\hline & 5 & 4.467 & \\
\hline
\end{tabular}

Powder Soray Welding 1 Layer Deposit 500 Scratches

Table 24

\begin{tabular}{|c|c|cc|}
\hline Load Kgs & Test No & \multicolumn{2}{|c|}{$\begin{array}{c}\text { Average } \\
\text { Wear Volume } \mathrm{mm}^{3}\end{array}$} \\
\hline \multirow{4}{*}{2.5} & 1 & 0.401 & \\
& 2 & 0.821 & \\
& 3 & 0.750 & 0.611 \\
& 4 & 0.611 & \\
& 5 & 0.473 & \\
\hline & 1 & 0.624 & \\
& 2 & 1.293 & \\
5 & 3 & 0.990 & 0.918 \\
& 4 & 0.893 & \\
& 5 & 0.890 & \\
\hline & 1 & 1.055 & \\
& 2 & 1.880 & \\
10 & 3 & 1.442 & 1.494 \\
& 4 & 1.327 & \\
& 5 & 1.769 & \\
\hline
\end{tabular}




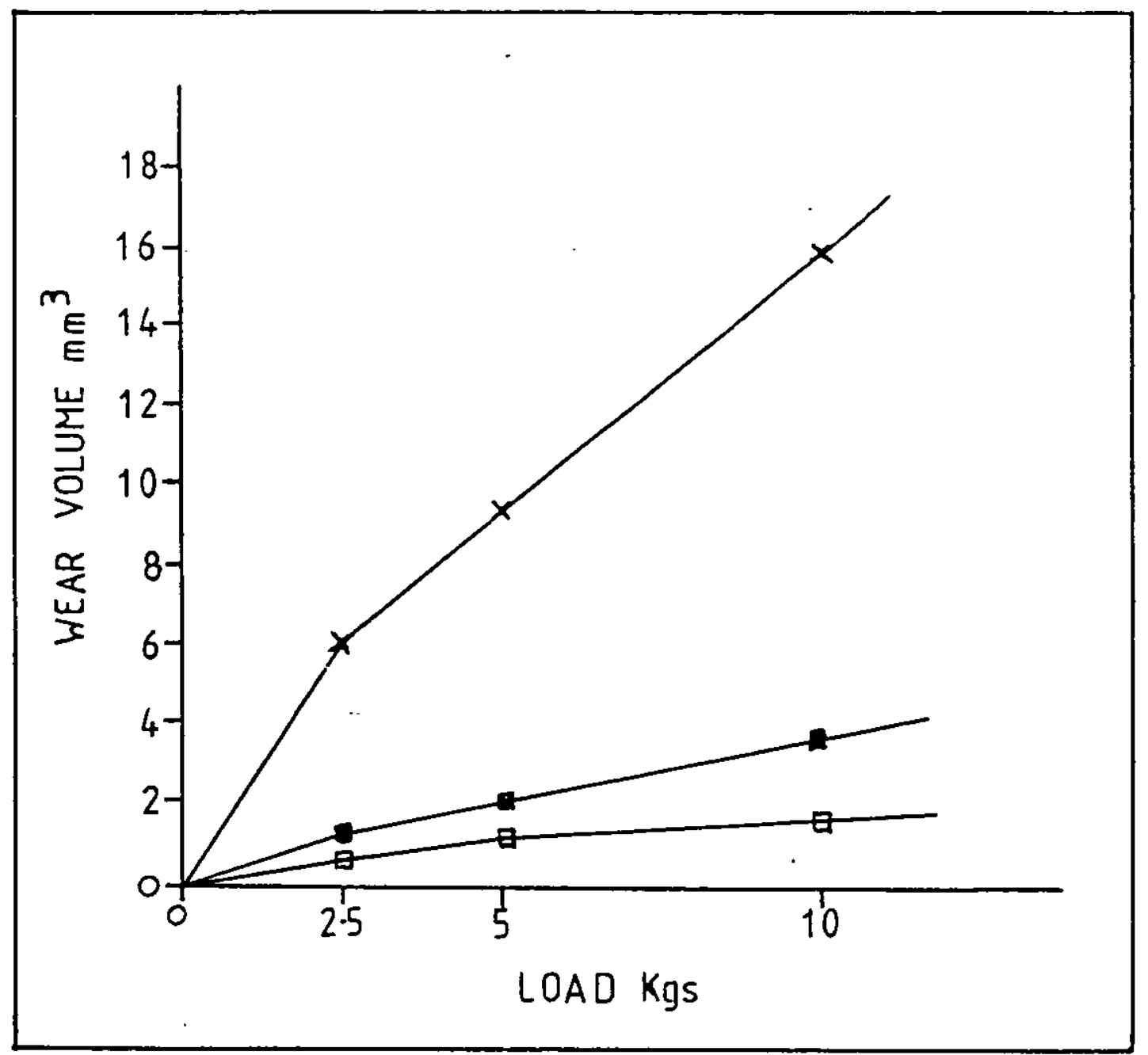

FIG 4.9 Wear Volume Vs Load POWDER SPRAYING 500 Scratches

$x=$ Cast Iron:

- 1 Layer Deposit

$\square=2$ Layer Deposits 
Table 25

\begin{tabular}{|c|c|c|c|}
\hline Load Kgs & Test No & $\begin{array}{r}\text { Ay } \\
\text { Wear }\end{array}$ & $\begin{array}{l}\text { age } \\
\text { lume } \mathrm{mm}^{3}\end{array}$ \\
\hline \multirow{5}{*}{$2 \cdot 5$} & 1 & $\cup 477$ & \multirow{5}{*}{0.259} \\
\hline & 2 & $0.50 ?$ & \\
\hline & 3 & 0.178 & \\
\hline & 4 & $0.17 z$ & \\
\hline & 5 & 0.162 & \\
\hline \multirow{5}{*}{5} & 1 & 0.978 & \multirow{5}{*}{$\underline{0.525}$} \\
\hline & 2 & 0.453 & \\
\hline & 3 & 0.430 & \\
\hline & 4 & 0.341 & \\
\hline & 5 & 0.477 & \\
\hline \multirow{5}{*}{10} & 1 & 1.040 & \multirow{5}{*}{0.762} \\
\hline & 2 & 0.759 & \\
\hline & 3 & 0.776 & \\
\hline & 4 & 0.509 & \\
\hline & 5 & 0.730 & \\
\hline
\end{tabular}

Table 26

\begin{tabular}{|c|c|cc|}
\hline Load Kgs & Test No & \multicolumn{2}{|c|}{$\begin{array}{c}\text { Average } \\
\text { Wear Volume min }\end{array}$} \\
\hline \multirow{4}{*}{2.5} & 1 & 0.251 & \\
& 2 & 0.116 & \\
& 3 & 0.152 & 0.177 \\
& 4 & 0.197 & \\
& 5 & 0.172 & \\
\hline & 1 & 0.263 & \\
5 & 2 & 0.213 & \\
& 3 & 0.244 & 0.245 \\
& 4 & 0.209 & \\
& 5 & 0.297 & \\
\hline & 1 & 0.456 & \\
& 2 & 0.418 & \\
10 & 3 & 0.431 & 0.433 \\
& 4 & 0.477 & \\
& 5 & 0.384 & \\
\hline
\end{tabular}

$\because 0 x y$ - Acetylene 2 Layer Deposits 10 Scratches 


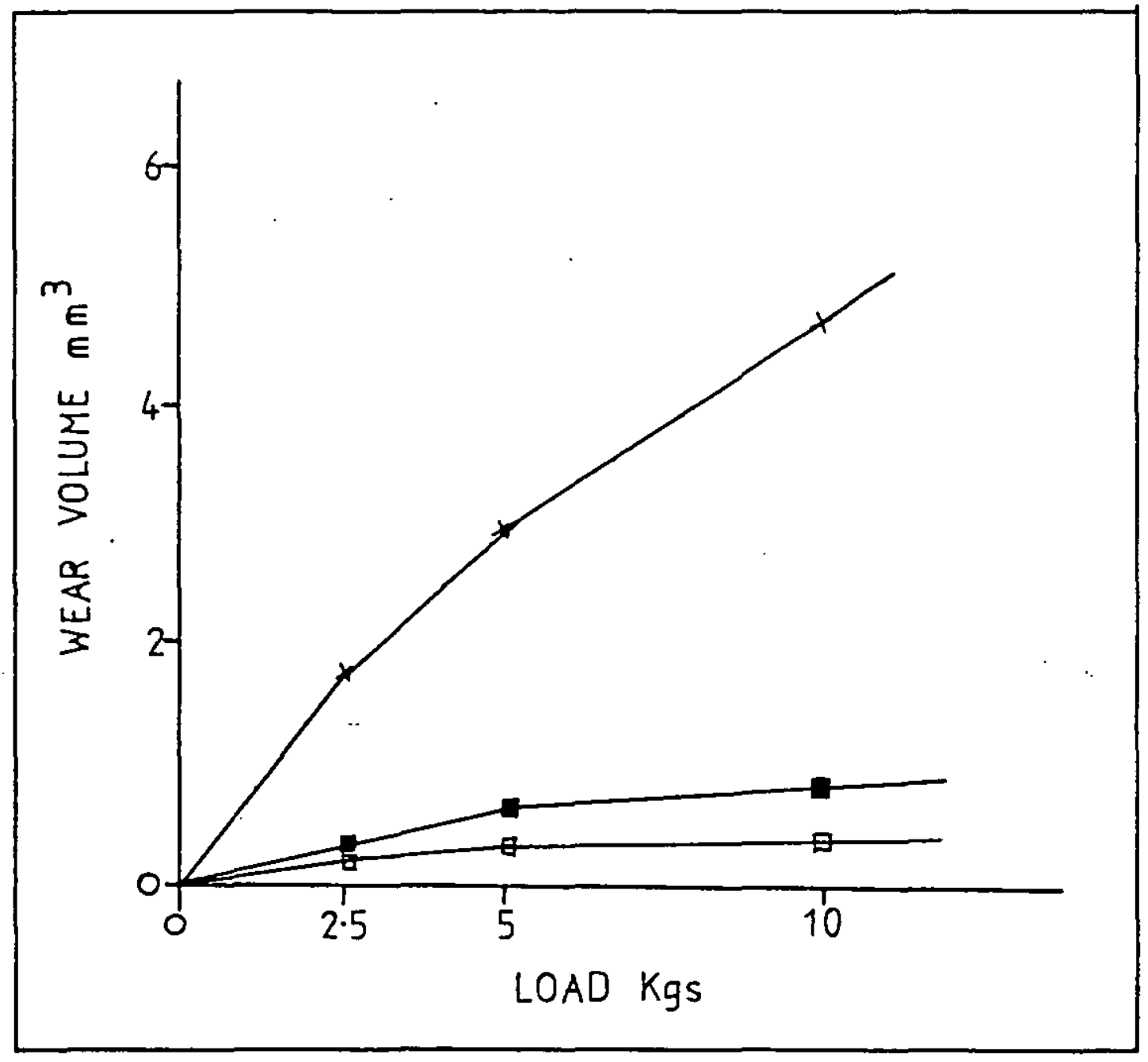

EIG 4.10 Wear Volume Vs Load. OXY - ACETYLENE 10 Scratches

$x=$ Cast Iron

- $=1$ Layer Deposit

$\mathrm{a}=2$ Layer Deposits 


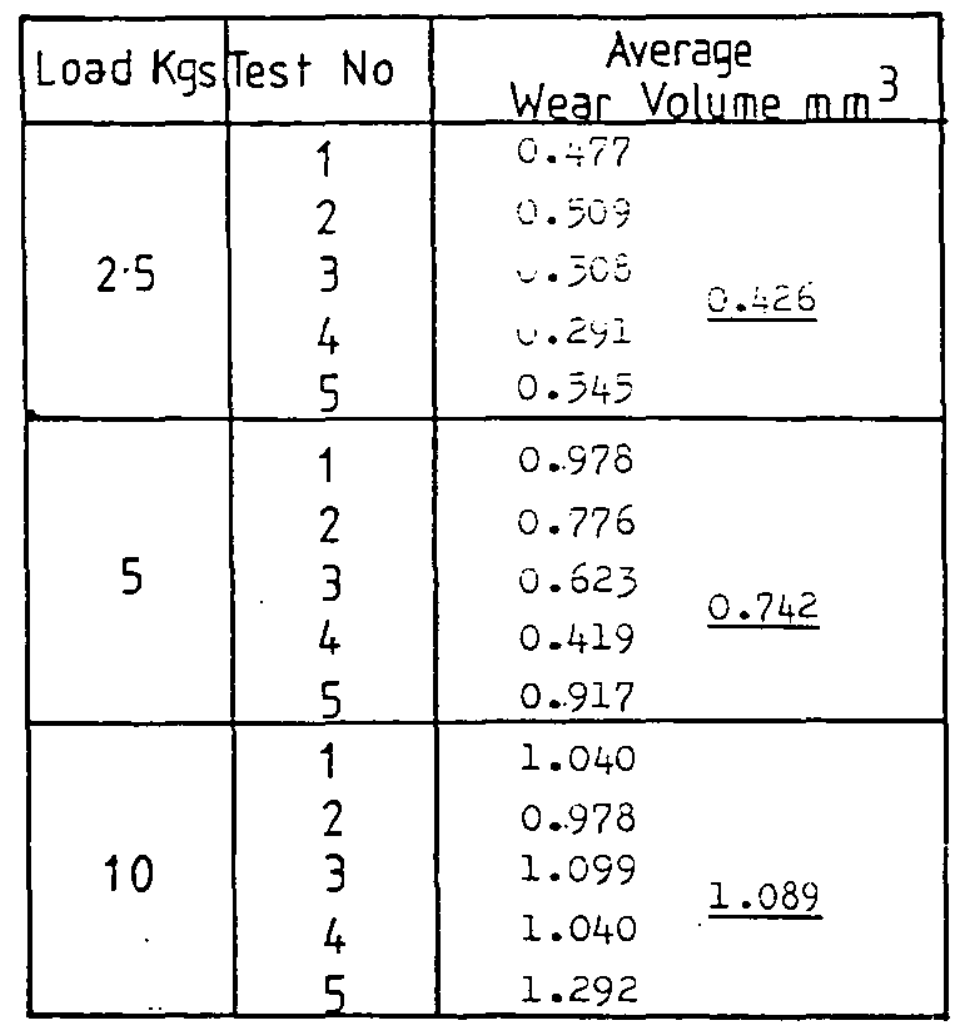

Oxy-Acetylene 1 Layer Deposit 50 Scratches

Table 28

\begin{tabular}{|c|c|cc|}
\hline Load Kgs & Test No & \multicolumn{2}{|c|}{$\begin{array}{c}\text { Average } \\
\text { Wear Volume m }{ }^{3}\end{array}$} \\
\hline \multirow{4}{*}{2.5} & 1 & 0.137 & \\
& 2 & 0.329 & \\
& 3 & 0.263 & 0.277 \\
& 4 & 0.308 & $\underline{ }$ \\
& 5 & 0.352 & \\
\hline & 1 & 0.545 & \\
& 2 & 0.668 & \\
5 & 3 & 0.402 & 0.595 \\
& 4 & 0.611 & \\
& 5 & 0.750 & \\
& 1 & 0.845 & \\
& 2 & 1.434 & \\
& 3 & 1.043 & 1.110 \\
& 4 & 0.902 & \\
& 5 & 1.327 & \\
\hline
\end{tabular}




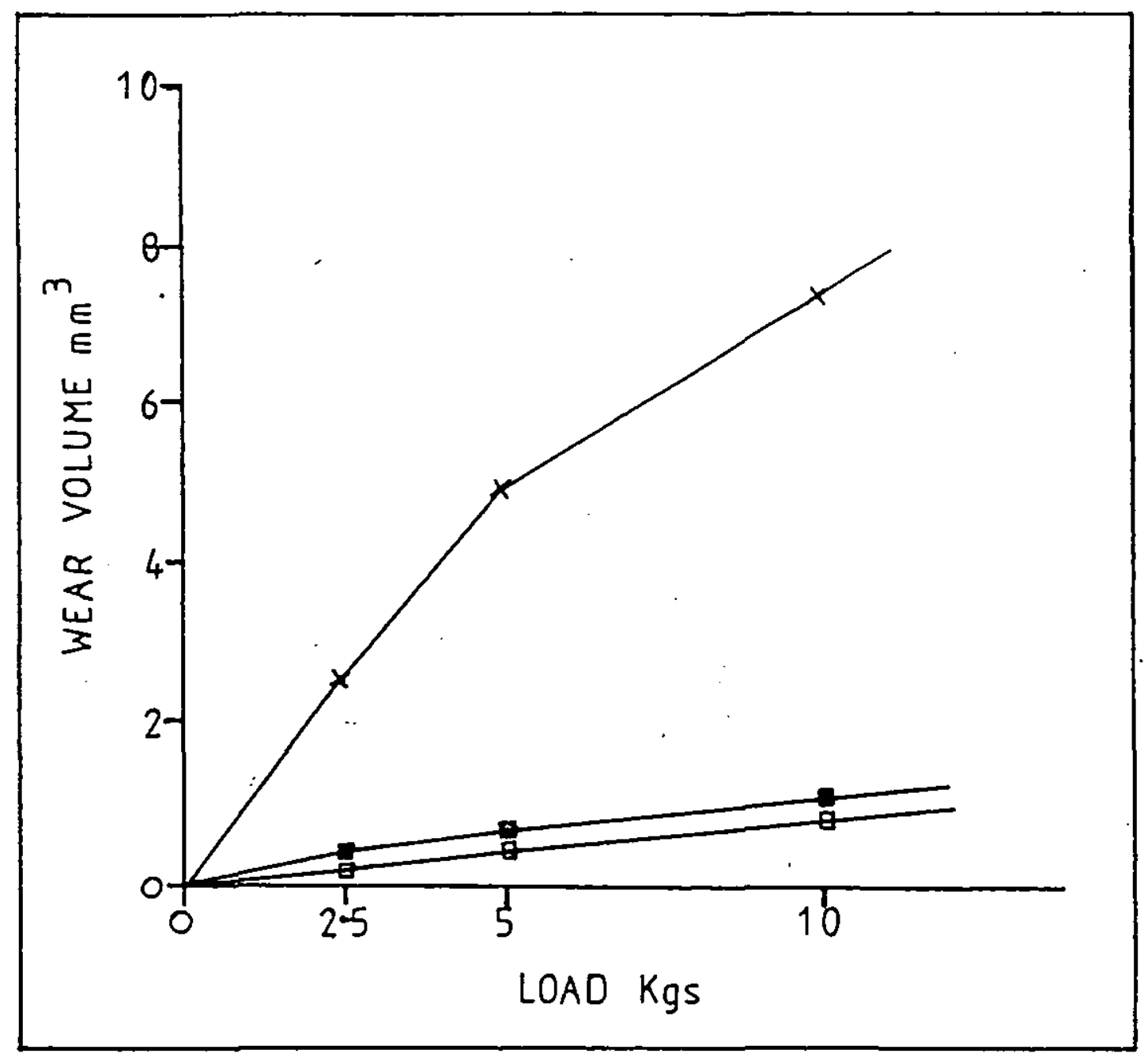

FIG 4.11 Wear Volume Vs Load

OXY-ACETYLENE 50 Scratches

$x=$ Cast Iron "

$\boldsymbol{w}=1$ Layer Deposit

$\square=2$ Layer Deposits 


\begin{tabular}{|c|c|c|c|}
\hline \multirow{2}{*}{ Load Kgs } & Test No & \multicolumn{2}{|c|}{$\begin{array}{c}\text { Average } \\
\text { Wear Volume } \mathrm{mm}^{3}\end{array}$} \\
\hline & 1 & $0.6 \div 4$ & \multirow{5}{*}{$0.6 \% 1$} \\
\hline \multirow{4}{*}{2.5} & 2 & 0.6064 & \\
\hline & 3 & 0.664 & \\
\hline & 4 & $\therefore .623$ & \\
\hline & 5 & 0.304 & \\
\hline \multirow{5}{*}{5} & 1 & 0.864 & \multirow{5}{*}{0.976} \\
\hline & 2 & 1.067 & \\
\hline & 3 & 0.734 & \\
\hline & 4 & 0.839 & \\
\hline & 5 & 1.376 & \\
\hline \multirow{5}{*}{10} & 1 & 2.229 & \multirow{5}{*}{1.518} \\
\hline & 2 & 1.285 & \\
\hline & 3 & 1.423 & \\
\hline & 4 & 1.667 & \\
\hline & 5 & 1.086 & \\
\hline
\end{tabular}

Oxy-Acetylene 1 Layer Deposit 100 Scratches

Table 30

\begin{tabular}{|c|c|cc|}
\hline Load Kgs & Test No & \multicolumn{2}{|c|}{$\begin{array}{c}\text { Average } \\
\text { Wear Volume m }{ }^{3}\end{array}$} \\
\hline \multirow{4}{*}{2.5} & 1 & 0.694 & \\
& 2 & 0.711 & \\
& 3 & 0.545 & 0.615 \\
& 4 & 0.582 & $\underline{0}$ \\
& 5 & 0.546 & \\
& 1 & 0.864 & \\
& 2 & 0.789 & \\
5 & 3 & 0.382 & 0.820 \\
& 4 & 0.726 & \\
& 5 & 0.839 & \\
\hline & 1 & 1.594 & \\
& 2 & 1.122 & \\
10 & 3 & 1.122 & 1.459 \\
& 4 & 1.790 & \\
& 5 & 1.667 & \\
\hline
\end{tabular}

$\therefore$ Oxy-Acetylene 2 Layer Deposits 100 Scratches 


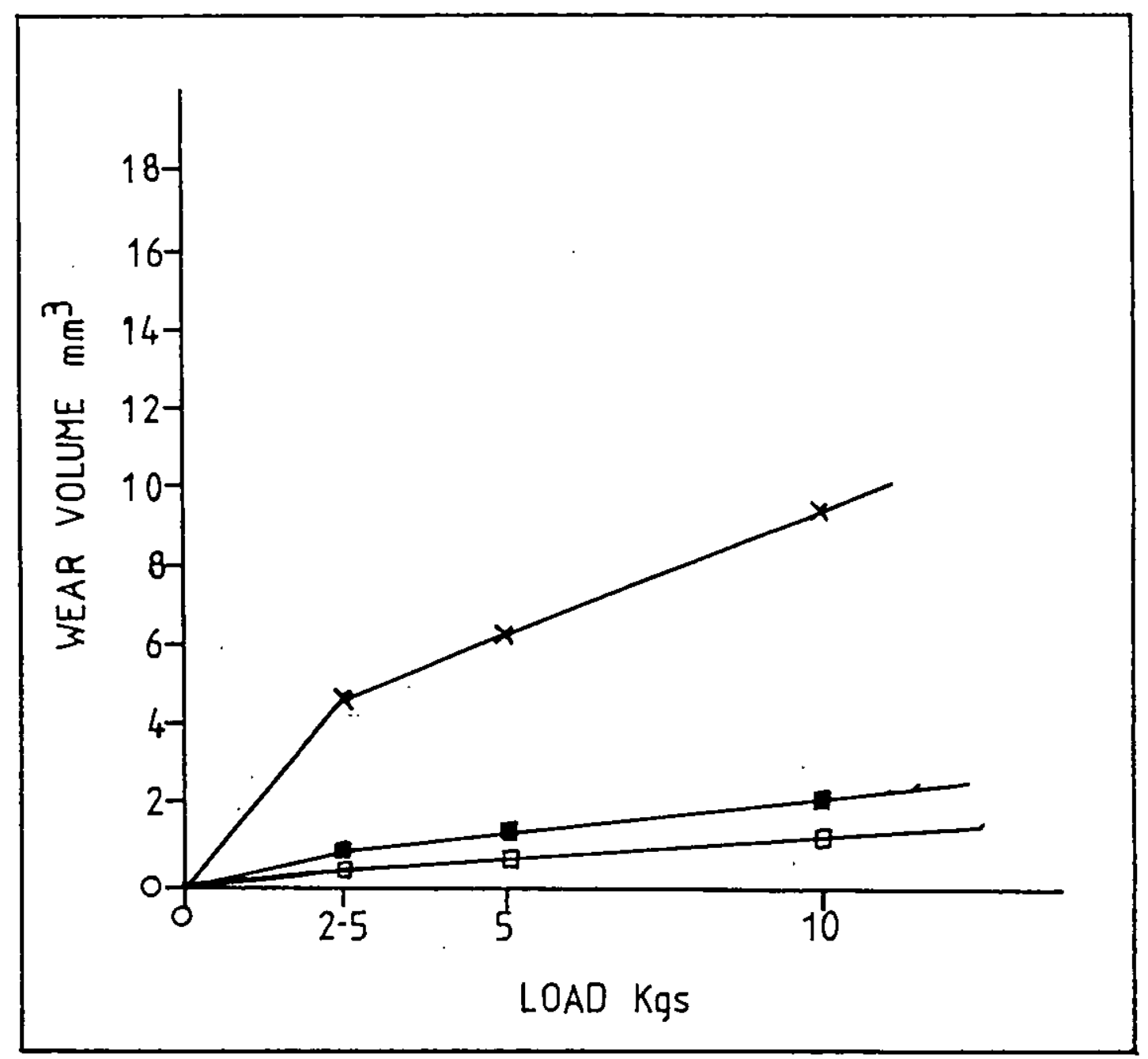

FIG 4.12 Wear Volume $V_{s}$ Load OXY - ACETYLENE 100 Scratches

$x=$ Cast Iron

= 1 Layer Deposit

$\square=2$ Layer Deposits 
Table 31

\begin{tabular}{|c|c|ll|}
\hline Load Kgs & Test No & \multicolumn{2}{|c|}{$\begin{array}{c}\text { Average } \\
\text { Wear Volume mo }\end{array}$} \\
\hline \multirow{4}{*}{2.5} & 1 & 1.213 & \\
& 2 & 1.456 & \\
& 3 & 1.375 & 1.476 \\
& 4 & 1.454 & \\
& 5 & 1.833 & \\
\hline & 1 & 3.497 & \\
& 2 & 3.655 & \\
5 & 3 & 3.245 & 3.327 \\
& 4 & 3.777 & \\
& 5 & 3.463 & \\
& 1 & 5.759 & \\
& 2 & 5.963 & \\
10 & 3 & 4.547 & 5.585 \\
& 4 & 5.901 & \\
& 5 & 5.759 \\
\hline
\end{tabular}

Oxy-Acetylene 1 Layer Deposit 500 Scratches

Table 32

\begin{tabular}{|c|c|ll|}
\hline Lod Kgs & Test No & \multicolumn{2}{|c|}{$\begin{array}{c}\text { Average } \\
\text { Wear Volume m m }\end{array}$} \\
\hline \multirow{4}{*}{2.5} & 1 & 0.438 & \\
& 2 & 1.623 & \\
& 3 & 0.645 & 0.913 \\
& 4 & 0.822 & $\underline{ }$ \\
& 5 & 1.040 & \\
\hline & 1 & 1.342 & \\
& 2 & 3.554 & \\
5 & 3 & 1.335 & 1.981 \\
& 4 & 1.534 & \\
& 5 & 2.093 & \\
& 1 & 2.870 & \\
& 2 & 5.929 \\
10 & 3 & 4.515 \\
& 4 & 2.735 & 4.244 \\
& 5 & 5.153 \\
\hline
\end{tabular}

$\because$ Oxy - Acetylene 2 Layer Deposits 500 Scratches 


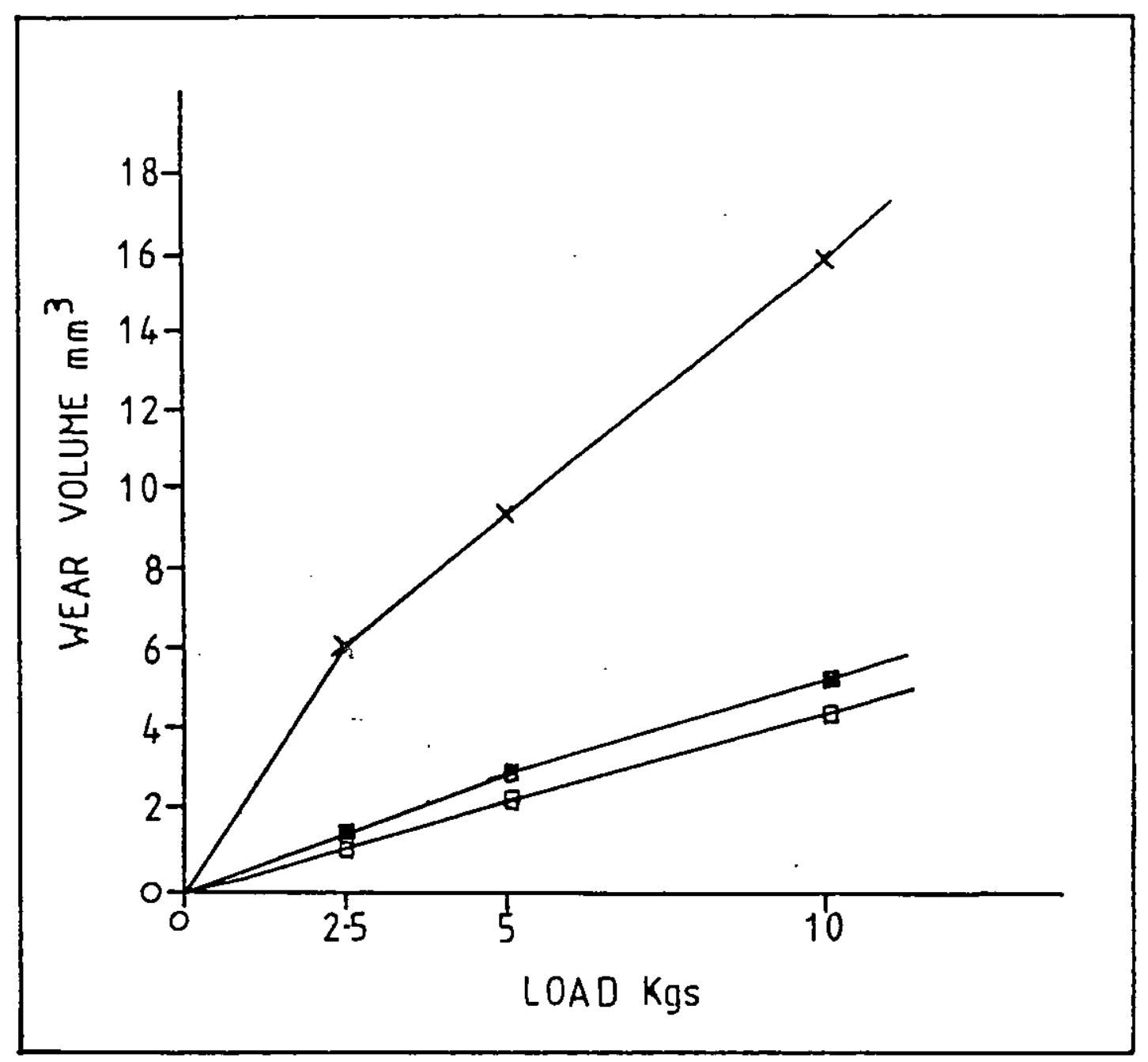

EIG 4.13 Wear Volume Vs Load OXY-ACETYLENE 500 Scratches

$x=$ Cast Iron:

$=1$ Layer Deposit

$\square=2$ Layer Deposits 


\begin{tabular}{|c|c|c|c|}
\hline Load Kgs & Test No & $\begin{array}{r}\text { Ave } \\
\text { Wear V }\end{array}$ & lume $\mathrm{nm}^{3}$ \\
\hline \multirow{5}{*}{$2 \cdot 5$} & 1 & 0.263 & \multirow{5}{*}{0.232} \\
\hline & 2 & $0 . \angle 79$ & \\
\hline & 3 & 0.394 & \\
\hline & 4 & 0.260 & \\
\hline & 5 & $0.24 i$ & \\
\hline \multirow{5}{*}{5} & 1 & 0.608 & \multirow{5}{*}{0.653} \\
\hline & 2 & 0.622 & \\
\hline & 3 & 0.673 & \\
\hline & 4 & 0.663 & \\
\hline & 5 & 0.623 & \\
\hline \multirow{5}{*}{10} & 1 & 1.078 & \multirow{5}{*}{1.096} \\
\hline & 2 & 1.199 & \\
\hline & 3 & 0.966 & \\
\hline & 4 & 1.213 & \\
\hline & 5 & 1.026 & \\
\hline
\end{tabular}

Iungsten Inert Gas 1 Layer Deposit 10 Scratches

Table 34

\begin{tabular}{|c|c|c|c|}
\hline Load Kgs & Test No & $\begin{array}{r}\text { Ave } \\
\text { Wear V }\end{array}$ & une $\mathrm{mm}^{3}$ \\
\hline \multirow{5}{*}{2.5} & 1 & 0.087 & \multirow{5}{*}{0.163} \\
\hline & 2 & $0 . \bar{\Sigma} 50$ & \\
\hline & 3 & 0.152 & \\
\hline & 4 & 0.213 & \\
\hline & 5 & 0.117 & \\
\hline \multirow{5}{*}{5} & 1 & 0.283 & \multirow{5}{*}{0.339} \\
\hline & 2 & 0.384 & \\
\hline & 3 & 0.330 & \\
\hline & 4 & 0.330 & \\
\hline & 5 & 0.368 & \\
\hline \multirow{5}{*}{10} & 1 & 0.439 & \multirow{5}{*}{0.713} \\
\hline & 2 & 1.037 & \\
\hline & 3 & 0.773 & \\
\hline & 4 & 0.663 & \\
\hline & 5 & 0.604 & \\
\hline
\end{tabular}

Iungsten Inert Gas 2.Layer Deposits 10 Scratches 


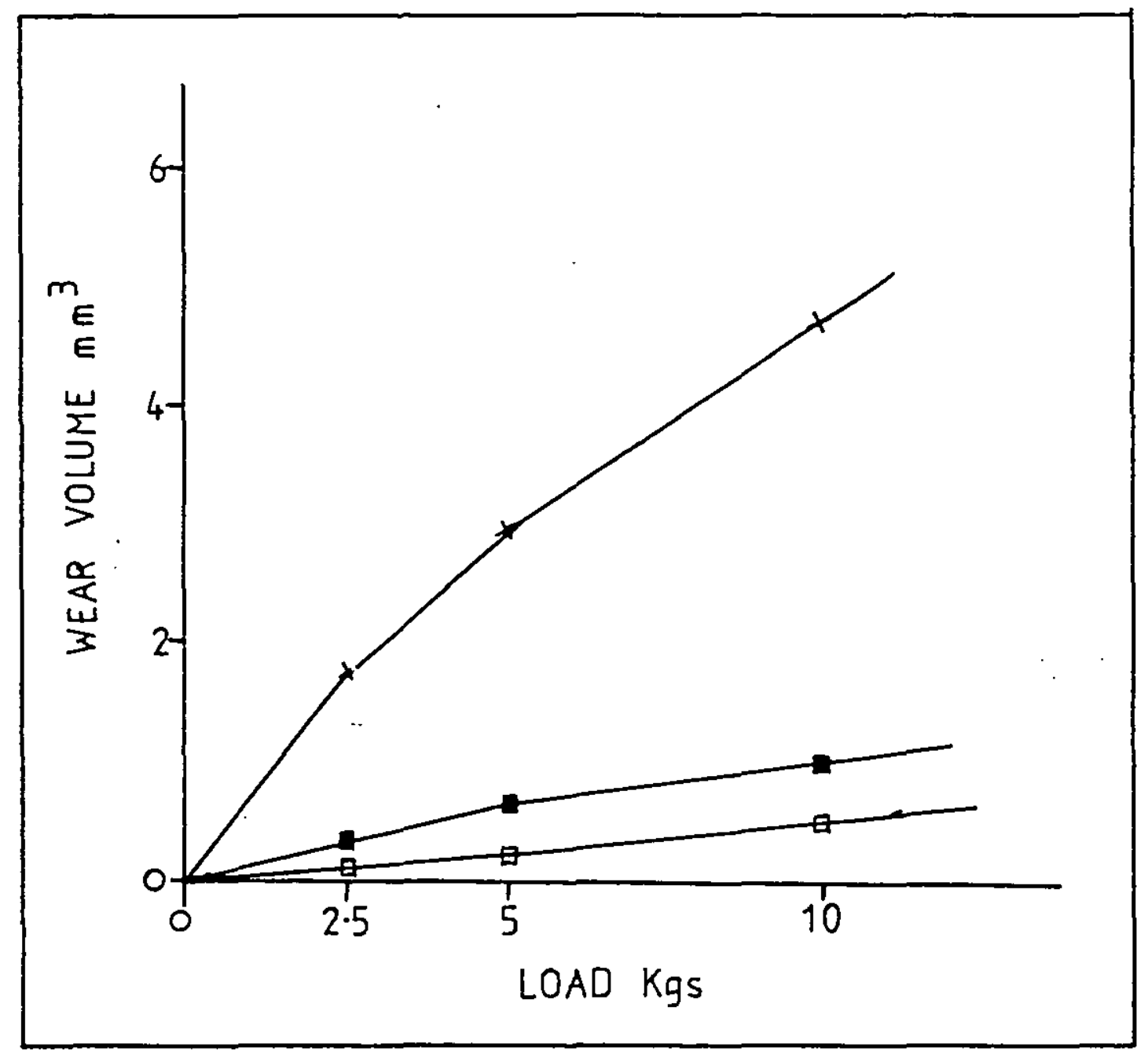

FIG 4.14 Wear Volume Vs Load. TUNGSTEN INERT GAS 10 Scratches

$$
\begin{aligned}
& x=\text { Cast Iron } \\
& \square=1 \text { Layer Deposit } \\
& \square=2 \text { Layer Deposits }
\end{aligned}
$$


Table 35

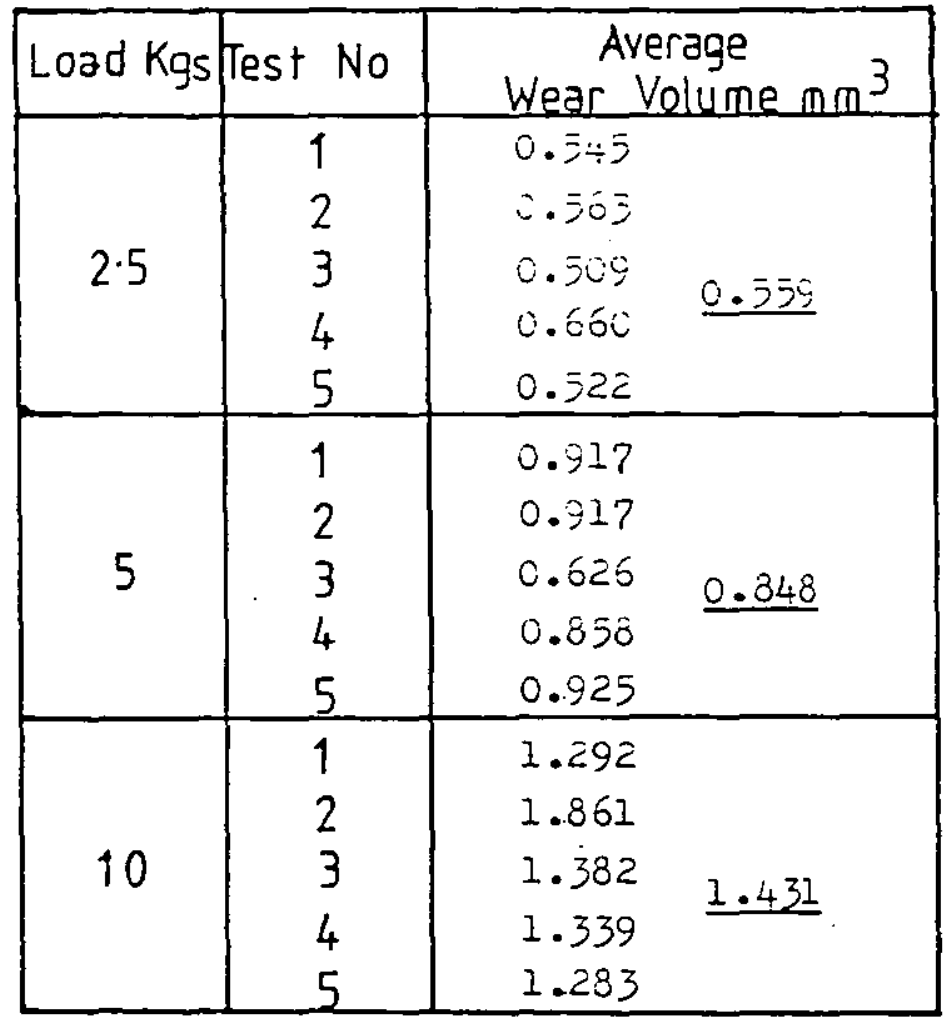

Iungsten Inert Gas 1 Layer Deposit 50 Scratches

Table 36

\begin{tabular}{|c|c|cc|}
\hline Load Kgs & Test No & \multicolumn{2}{|c|}{$\begin{array}{c}\text { Average } \\
\text { Wear Volume m m }\end{array}$} \\
\hline \multirow{4}{*}{2.5} & 1 & 0.422 & \\
& 2 & 0.399 & \\
& 3 & 0.363 & 0.412 \\
& 4 & 0.384 & - \\
& 5 & 0.491 & \\
\hline & 1 & 0.663 & \\
5 & 2 & 0.847 & \\
5 & 3 & 0.752 & 0.729 \\
& 4 & 0.604 & \\
& 5 & 0.779 & \\
& 1 & 1.220 & \\
& 2 & 1.434 & \\
10 & 3 & 1.382 & 1.326 \\
& 4 & 1.327 & \\
& 5 & 1.267 \\
\hline
\end{tabular}




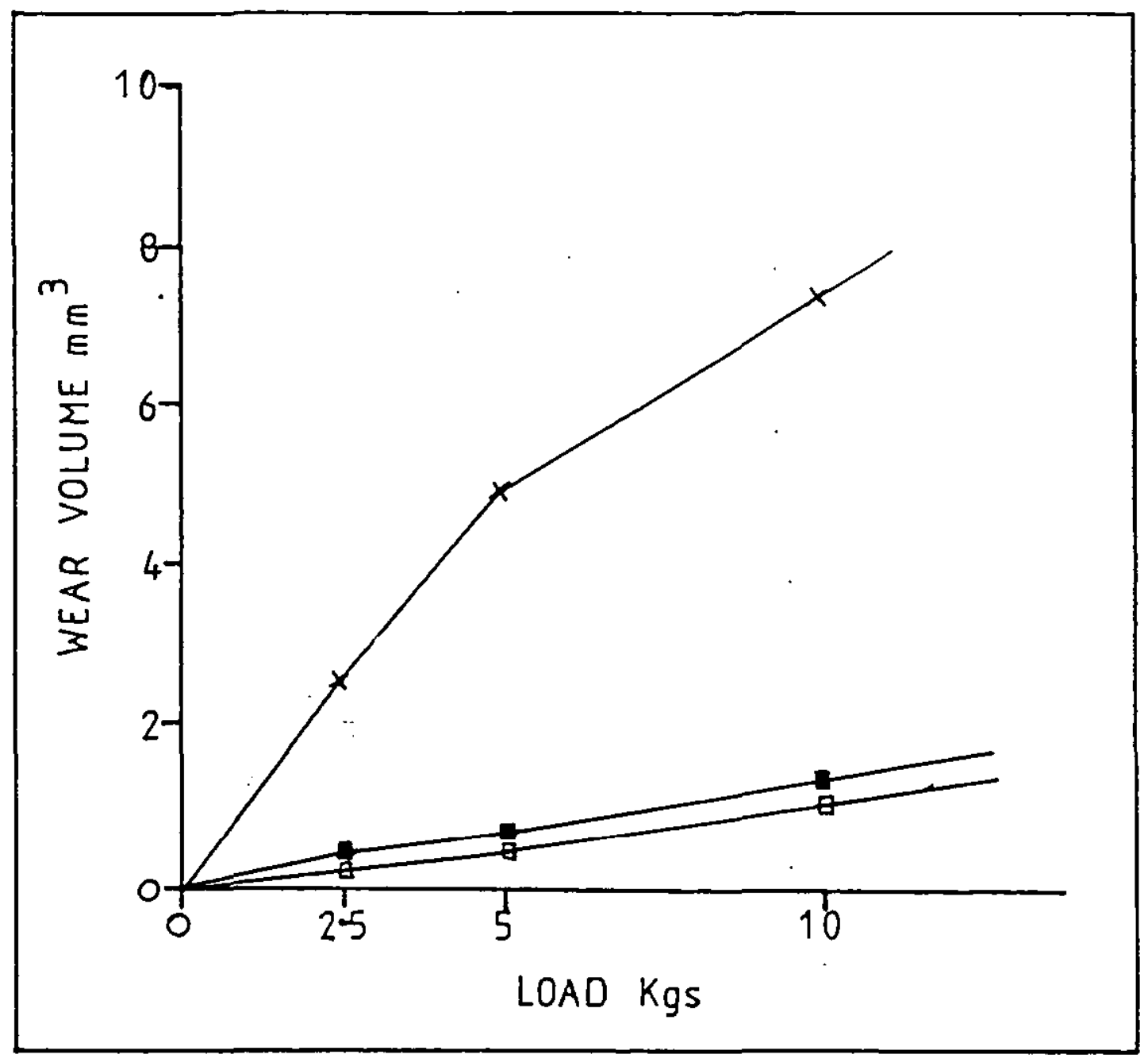

FIG 4.15 Wear Volume Vs Load IUNGSTEN INERT GAS 50 Scratches

$$
x=\text { Cast Iron . }
$$

- $=1$ Layer Deposit

$\square=2$ Layer Deposits 
Table 37

\begin{tabular}{|c|c|c|c|}
\hline Load Kgs & Test No & $\begin{array}{c}\text { Av } \\
\text { Wear }\end{array}$ & $\begin{array}{l}\text { rage } \\
\text { olume } \mathrm{m}^{3}\end{array}$ \\
\hline $2 \cdot 5$ & $\begin{array}{l}1 \\
2 \\
3 \\
4 \\
5\end{array}$ & $\begin{array}{l}0.720 \\
0.063 \\
1.245 \\
1.496 \\
0.663\end{array}$ & $0.9=0$ \\
\hline 5 & $\begin{array}{l}1 \\
2 \\
3 \\
4 \\
5\end{array}$ & $\begin{array}{l}1.383 \\
1.099 \\
1.951 \\
2.582 \\
1.591\end{array}$ & 1.721 \\
\hline 10 & $\begin{array}{l}1 \\
2 \\
3 \\
4 \\
5\end{array}$ & $\begin{array}{l}2.743 \\
1.667 \\
3.580 \\
4.160 \\
2.479\end{array}$ & 2. 925 \\
\hline
\end{tabular}

Iungsten Inert Gas 1 Layer Deposit 100 Scratshes

Table 38

\begin{tabular}{|c|c|cc|}
\hline Lod Kgs & Test No & \multicolumn{2}{|c|}{$\begin{array}{c}\text { Average } \\
\text { Wear Volume m }{ }^{3}\end{array}$} \\
\hline \multirow{4}{*}{2.5} & 1 & 0.931 & \\
& 2 & 1.055 & \\
& 3 & 0.964 & 0.926 \\
& 4 & 0.752 & \\
& 5 & 0.931 & \\
\hline & 1 & 1.464 & \\
& 2 & 1.551 & \\
5 & 3 & 1.655 & 1.374 \\
& 4 & 0.319 & \\
& 5 & 1.382 & \\
\hline & 1 & 2.109 & \\
& 2 & 2.725 & \\
10 & 3 & 2.596 & 2.287 \\
& 4 & 1.824 & \\
& 5 & 2.182 & \\
\hline
\end{tabular}

Tüngsten Inert Gas 2 Layer Deposits 100 Scratches 


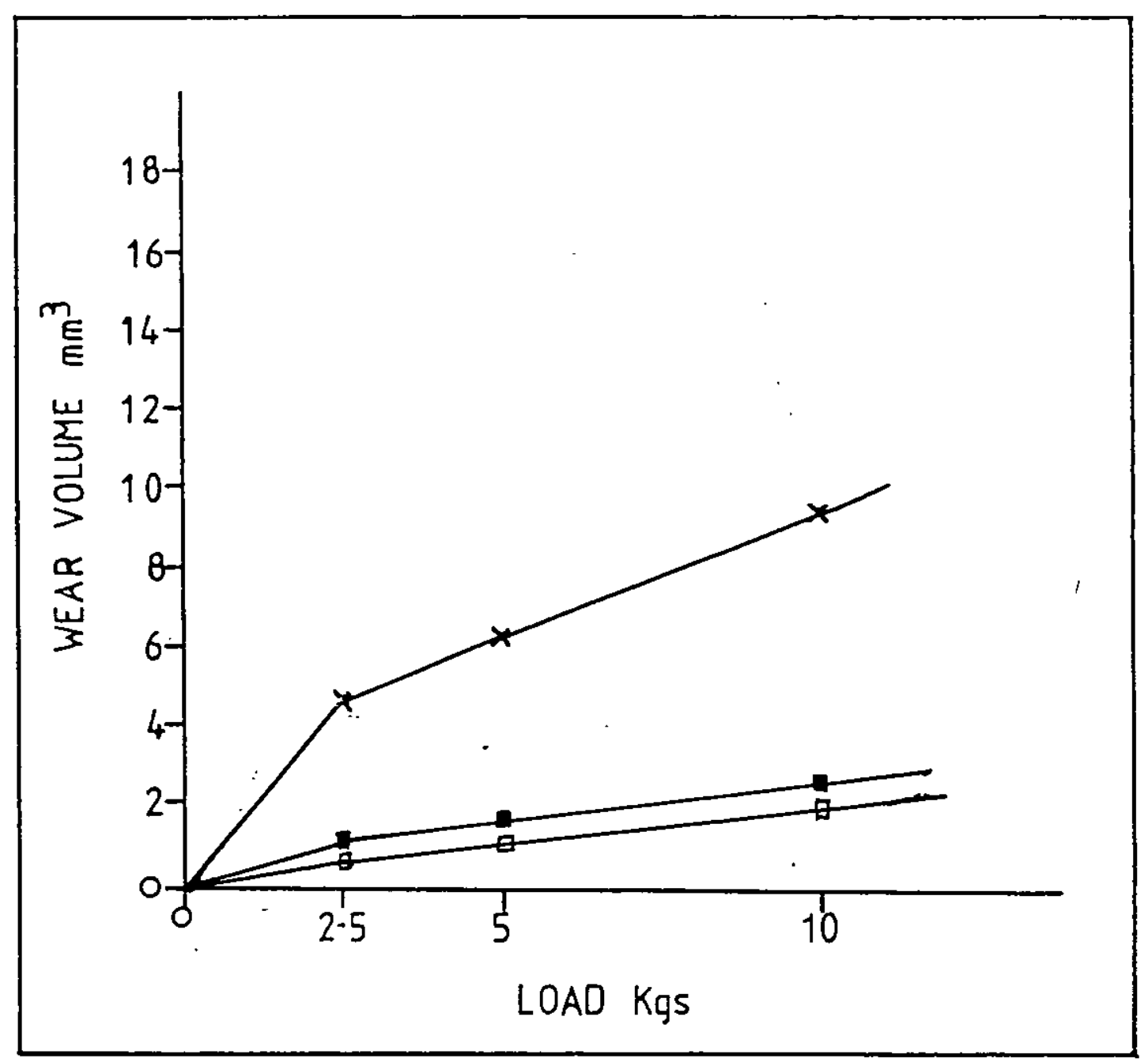

FIG 4.16 Wear Volume $V_{s}$ Load TUNGSTEN INERT GAS 100 Scratches

$$
\begin{aligned}
& x=\text { Cast Iron } \\
& u=1 \text { Layer Deposit } \\
& \square=2 \text { Layer Deposits }
\end{aligned}
$$




\begin{tabular}{|c|c|c|c|}
\hline Load Kgs & Test No & $\begin{array}{r}A \\
\text { Wear }\end{array}$ & $\begin{array}{l}\text { rage } \\
\text { lume } \mathrm{mm}^{3}\end{array}$ \\
\hline \multirow{5}{*}{$2 \cdot 5$} & 1 & 1.614 & \multirow{5}{*}{2.481} \\
\hline & 2 & 2.900 & \\
\hline & 3 & 2.057 & \\
\hline & 4 & 3.655 & \\
\hline & 5 & 2.233 & \\
\hline \multirow{5}{*}{5} & 1 & 3.831 & \multirow{5}{*}{$\underline{4.951}$} \\
\hline & 2 & 4.025 & \\
\hline & 3 & 4.121 & \\
\hline & 4 & 5.963 & \\
\hline & 5 & 6.818 & \\
\hline \multirow{5}{*}{10} & 1 & 6.695 & \multirow{5}{*}{$\underline{6.855}$} \\
\hline & 2 & 6.611 & \\
\hline & 3 & 6.427 & \\
\hline & 4 & 7.435 & \\
\hline & 5 & 7.058 & \\
\hline
\end{tabular}

Tungsten Inert Gas 1 Layer Deposit 500 Scratches

Table 40

\begin{tabular}{|c|c|ll|}
\hline Load Kgs & Test No & \multicolumn{2}{|c|}{$\begin{array}{c}\text { Average } \\
\text { Wear Volume m m }\end{array}$} \\
\hline \multirow{4}{*}{2.5} & 1 & 1.255 & \\
& 2 & 1.560 & \\
& 3 & 0.939 & 1.370 \\
& 4 & 1.383 & \\
& 5 & 1.667 & \\
\hline & 1 & 2.741 & \\
& 2 & 2.618 & \\
5 & 3 & 1.880 & 2.590 \\
& 4 & 2.960 & \\
& 5 & 2.743 & \\
& 1 & 3.655 & \\
& 2 & 4.109 & \\
10 & 3 & 3.132 & 3.750 \\
& 4 & 3.331 & \\
& 5 & 4.025 \\
\hline
\end{tabular}

Iungsten Inert Gas 2 Layer Deposits 500 Scratches 


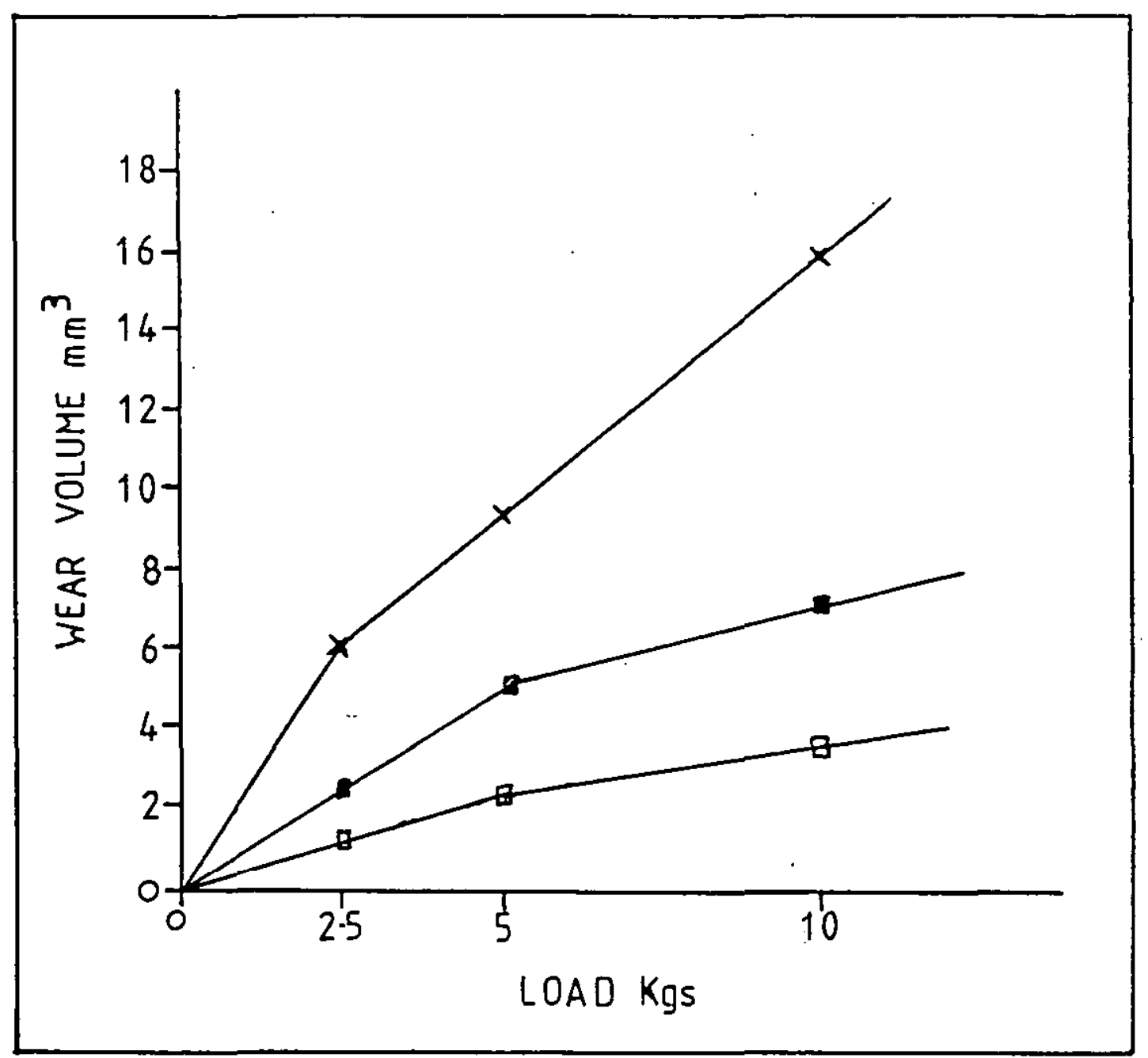

\section{FIG 4.17 Wear Volume Vs Load IUNGSTEN INERT GAS 500 Scratches}

$$
\begin{aligned}
& x=\text { Cast Iron: } \\
& \square=1 \text { Layer Deposit } \\
& \square=2 \text { Layer Deposits }
\end{aligned}
$$



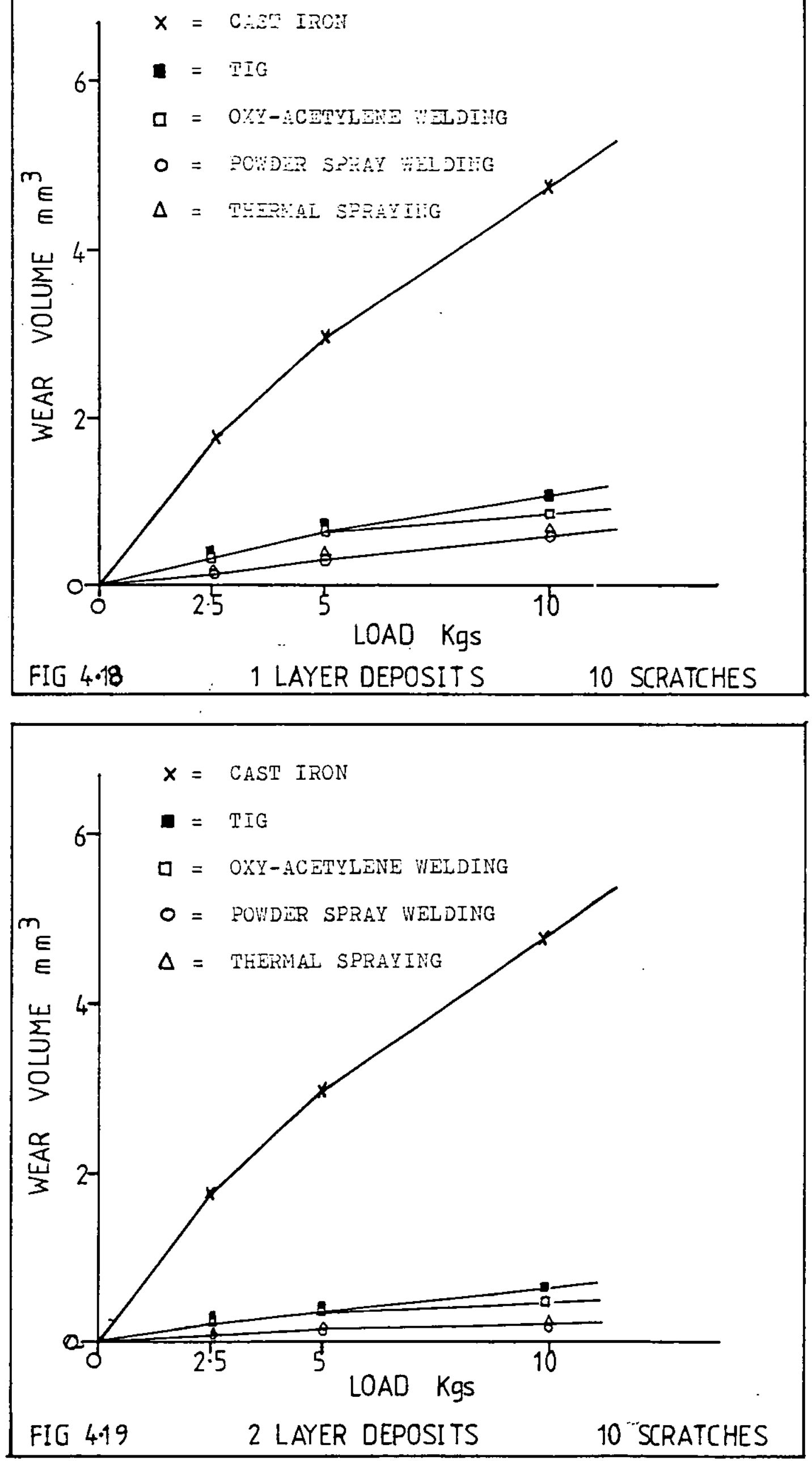

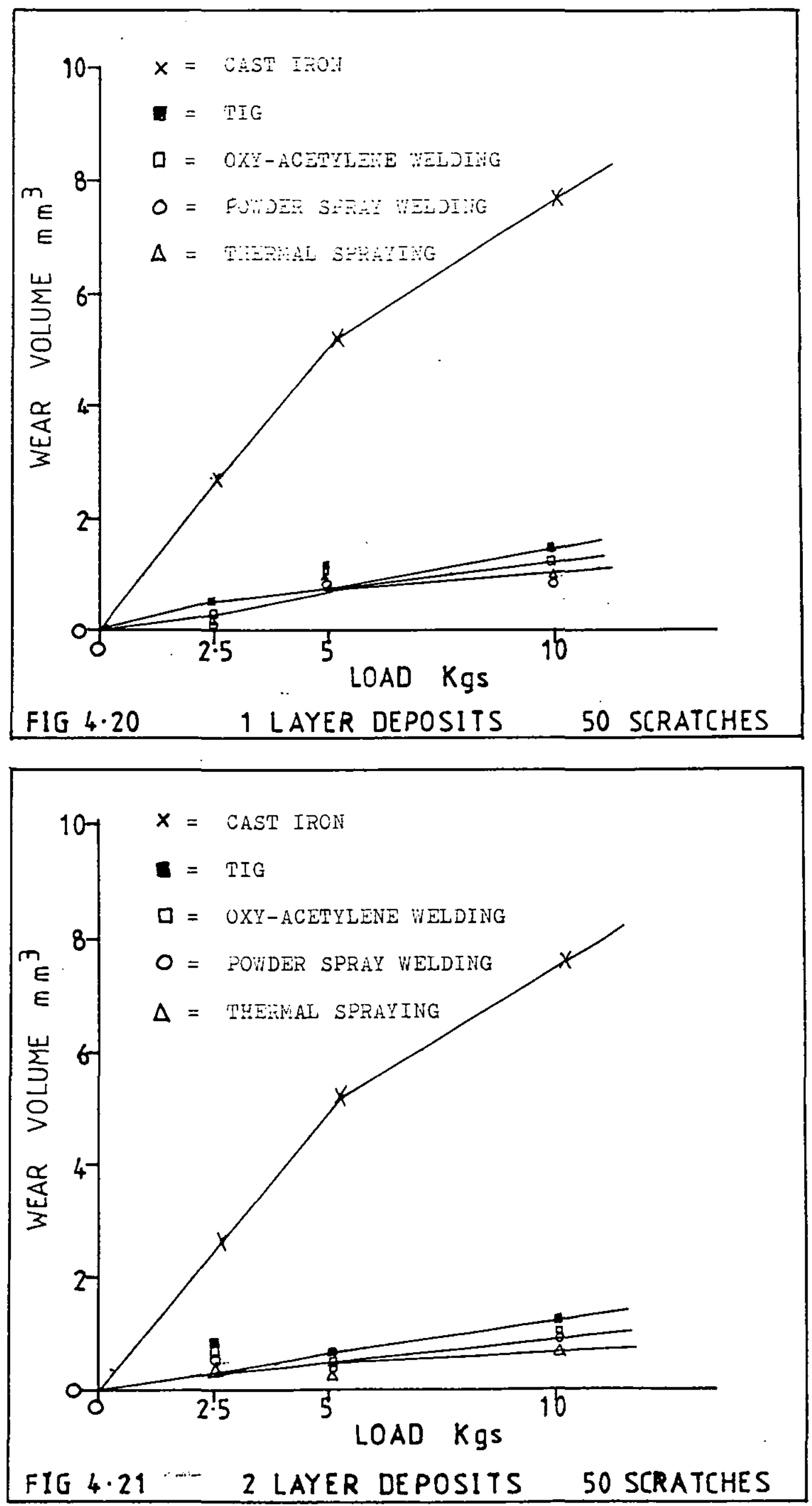

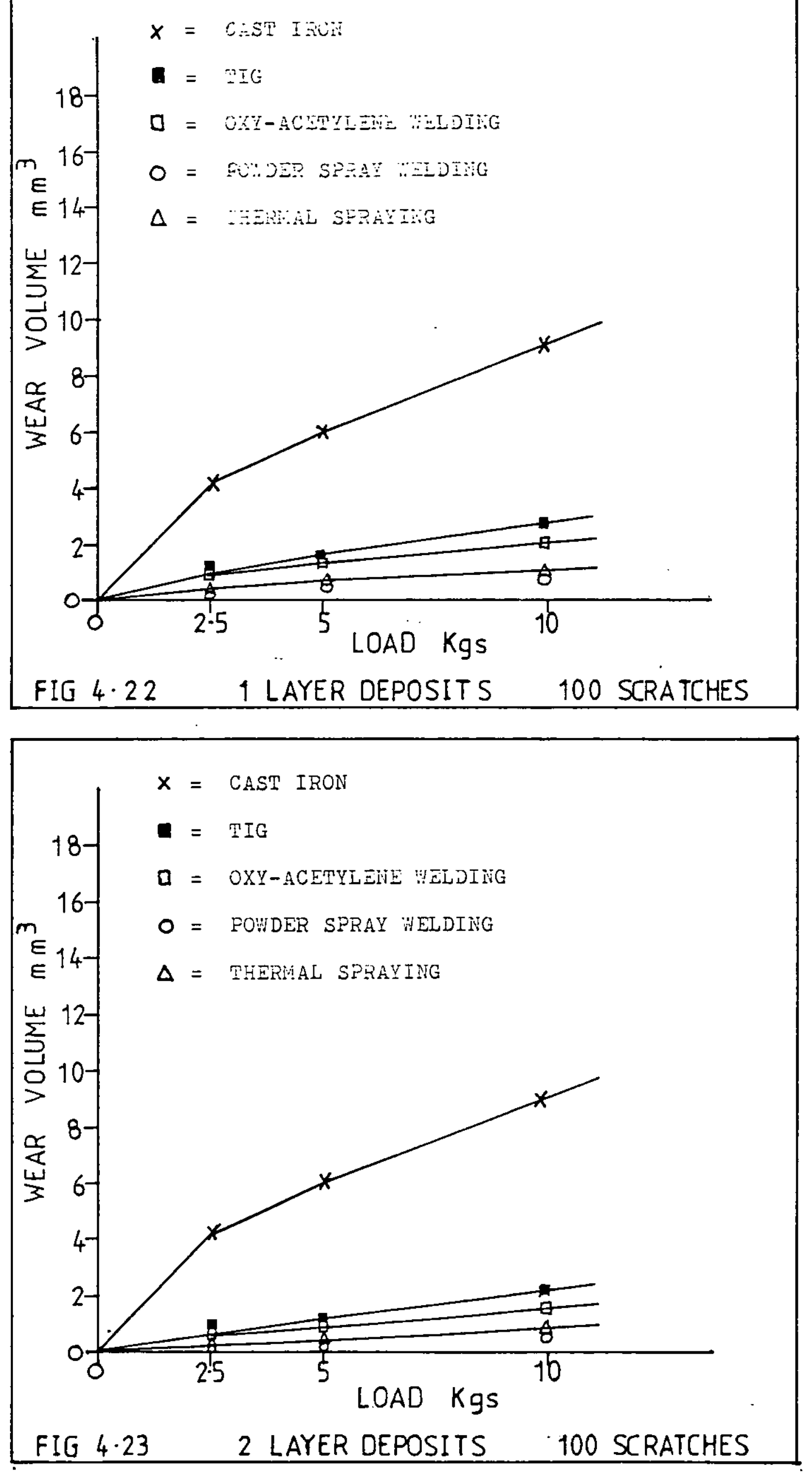

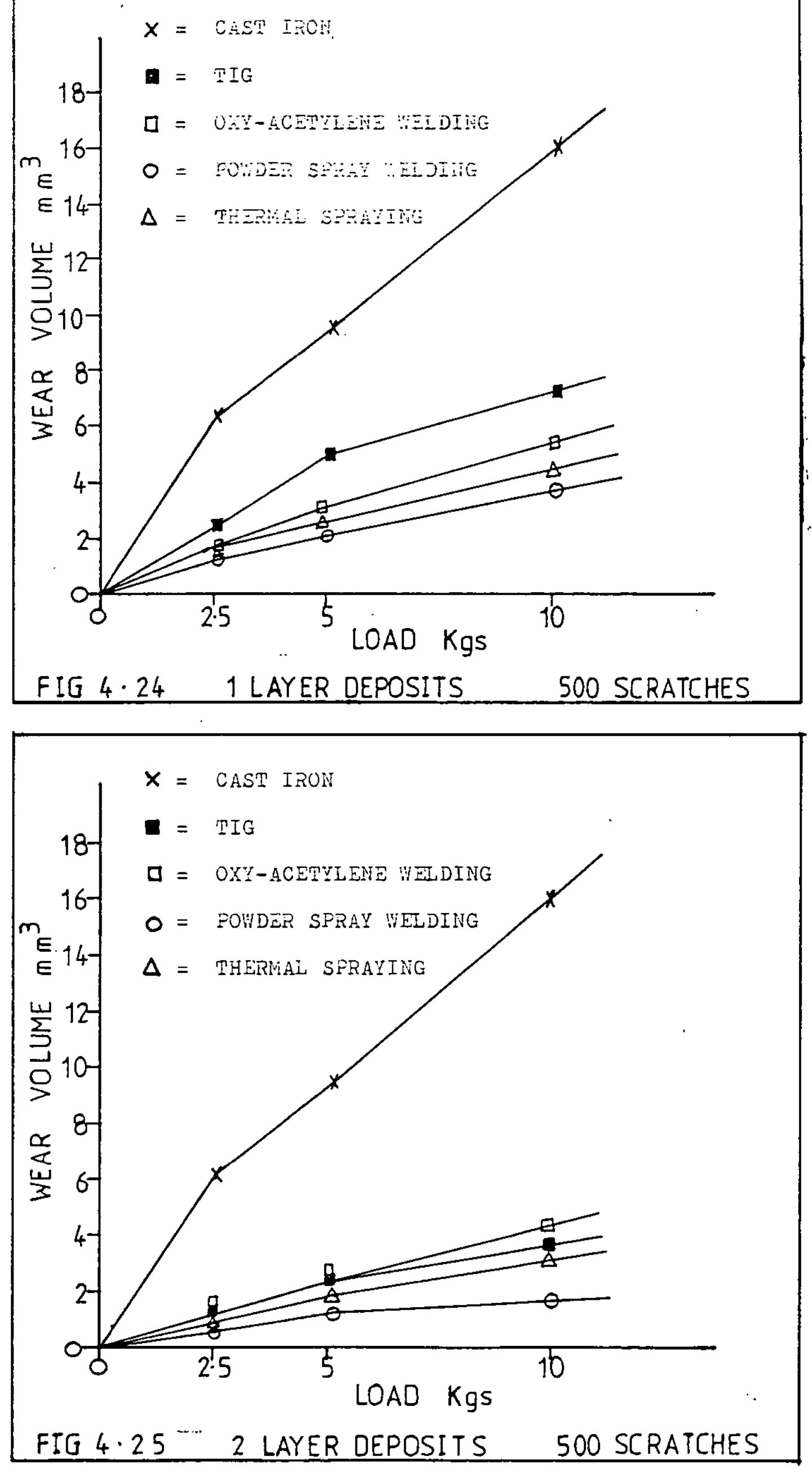
Table 41

\begin{tabular}{|c|c|c|c|c|c|c|}
\hline \multirow[b]{2}{*}{ Test No } & \multicolumn{2}{|c|}{ Grey Cast Iron } & \multicolumn{2}{|c|}{1 Layer Deposit } & \multicolumn{2}{|c|}{2 Layer Deposits } \\
\hline & $R$ b & ${ }^{*} E Q H V$ & $R 6$ & EQ HV & $R c$ & EQ HV \\
\hline 1 & $\begin{array}{l}99 \\
99 \\
98 \\
99 \\
99\end{array}$ & $\begin{array}{l}250 \\
2 \equiv 0 \\
2=4 \\
250 \\
2 \equiv 0\end{array}$ & $\begin{array}{l}52 \\
50 \\
54 \\
52 \\
50 \\
50\end{array}$ & $\begin{array}{l}570 \\
343 \\
608 \\
570 \\
543\end{array}$ & $\begin{array}{l}56 \\
54 \\
52 \\
52 \\
52\end{array}$ & $\begin{array}{l}640 \\
600 \\
570 \\
570 \\
570\end{array}$ \\
\hline Average & 99 & 223 & 51 & 567 & 55 & 593 \\
\hline 2 & $\begin{array}{l}97 \\
96 \\
98 \\
98 \\
98\end{array}$ & $\begin{array}{l}213 \\
212 \\
224 \\
224 \\
224\end{array}$ & $\begin{array}{l}54 \\
54 \\
56 \\
56 \\
56\end{array}$ & $\begin{array}{l}608 \\
608 \\
648 \\
648 \\
648\end{array}$ & $\begin{array}{l}62 \\
60 \\
60 \\
62 \\
60\end{array}$ & $\begin{array}{l}792 \\
736 \\
736 \\
792 \\
736\end{array}$ \\
\hline Average & $9 \cdot 7$ & 220 & 55 & 632 & $6 i$ & 758 \\
\hline 3 & $\begin{array}{l}97 \\
97 \\
96 \\
98 \\
98\end{array}$ & $\begin{array}{l}218 \\
218 \\
212 \\
224 \\
224\end{array}$ & $\begin{array}{l}50 \\
50 \\
52 \\
54 \\
54\end{array}$ & $\begin{array}{l}543 \\
543 \\
570 \\
608 \\
608\end{array}$ & $\begin{array}{l}56 \\
56 \\
56 \\
60 \\
60\end{array}$ & $\begin{array}{l}648 \\
648 \\
648 \\
736 \\
736\end{array}$ \\
\hline Average & 97 & 219 & 52. & 574 & 57 & 683 \\
\hline 4 & $\begin{array}{l}98 \\
98 \\
98 \\
98 \\
98\end{array}$ & $\begin{array}{l}224 \\
224 \\
224 \\
224 \\
224\end{array}$ & $\begin{array}{l}58 \\
58 \\
56 \\
56 \\
56\end{array}$ & $\begin{array}{l}685 \\
685 \\
648 \\
648 \\
648\end{array}$ & $\begin{array}{l}58 \\
56 \\
62 \\
65 \\
62\end{array}$ & $\begin{array}{l}685 \\
648 \\
792 \\
833 \\
792\end{array}$ \\
\hline Average & 98 & 224 & 57 & 662 & 60 & 750 \\
\hline 5 & $\begin{array}{l}99 \\
99 \\
99 \\
98 \\
99\end{array}$ & $\begin{array}{l}230 \\
230 \\
250 \\
224 \\
230\end{array}$ & $\begin{array}{l}52 \\
54 \\
54 \\
52 \\
52\end{array}$ & $\begin{array}{l}570 \\
608 \\
608 \\
570 \\
570\end{array}$ & $\begin{array}{l}63 \\
63 \\
63 \\
62 \\
62\end{array}$ & $\begin{array}{l}833 \\
833 \\
833 \\
792 \\
792\end{array}$ \\
\hline Average & 99 & 228 & 53 & 585 & 62 & 816 \\
\hline $\begin{array}{c}\text { Tatal } \\
\text { Average }\end{array}$ & 98 & 223 & 53 & 604 & 58 & 720 \\
\hline
\end{tabular}


Table 42

\begin{tabular}{|c|c|c|c|c|c|c|}
\hline \multirow[b]{2}{*}{ Test No } & \multicolumn{2}{|c|}{ Grey Cast Iron } & \multicolumn{2}{|c|}{1 Layer Deposit } & \multicolumn{2}{|c|}{2 Layer Deposits } \\
\hline & Rb & ${ }^{*} E Q H V$ & $R c$ & EQ HV & $R c$ & EQ HV \\
\hline 1 & $\begin{array}{l}90 \\
99 \\
98 \\
99 \\
99\end{array}$ & $\begin{array}{l}230 \\
230 \\
224 \\
230 \\
230\end{array}$ & $\begin{array}{l}62 \\
56 \\
53 \\
53 \\
53\end{array}$ & $\begin{array}{l}792 \\
648 \\
590 \\
398 \\
598\end{array}$ & $\begin{array}{l}34 \\
62 \\
64 \\
64 \\
64\end{array}$ & $\begin{array}{l}600 \\
792 \\
370 \\
670 \\
870\end{array}$ \\
\hline Average & 99 & 228 & 53 & 647 & 61 & 802 \\
\hline 2 & $\begin{array}{l}97 \\
96 \\
98 \\
98 \\
98\end{array}$ & $\begin{array}{l}218 \\
212 \\
224 \\
224 \\
224\end{array}$ & $\begin{array}{l}54 \\
54 \\
56 \\
56 \\
56\end{array}$ & $\begin{array}{l}608 \\
608 \\
648 \\
648 \\
648\end{array}$ & $\begin{array}{l}56 \\
62 \\
58 \\
65 \\
64\end{array}$ & $\begin{array}{l}648 \\
792 \\
685 \\
900 \\
870\end{array}$ \\
\hline Average & 97. & 220 & 55 & 632 & 61 & 779 \\
\hline 3 & $\begin{array}{l}97 \\
97 . \\
96 \\
98 \\
98\end{array}$ & $\begin{array}{l}218 \\
218 \\
212 \\
224 \\
224\end{array}$ & $\begin{array}{l}54 \\
54 \\
54 \\
54 \\
54\end{array}$ & $\begin{array}{l}608 \\
608 \\
608 \\
608 \\
608\end{array}$ & $\begin{array}{l}54 \\
52 \\
60 \\
64 \\
64\end{array}$ & $\begin{array}{l}608 \\
570 \\
736 \\
870 \\
870\end{array}$ \\
\hline Average & 97. & 219 & 54 & 608 & 58 & 730 \\
\hline 4 & $\begin{array}{l}98 \\
98 \\
98 \\
98 \\
98\end{array}$ & $\begin{array}{l}224 \\
224 \\
224 \\
224 \\
224\end{array}$ & $\begin{array}{l}56 \\
53 \\
53 \\
54 \\
54\end{array}$ & $\begin{array}{l}648 \\
598 \\
598 \\
608 \\
608\end{array}$ & $\begin{array}{l}57 \\
63 \\
65 \\
66 \\
65\end{array}$ & $\begin{array}{l}666 \\
833 \\
900 \\
940 \\
900\end{array}$ \\
\hline Average & 98 & 224 & 54 & 612 & 63 & 848 \\
\hline 5 & $\begin{array}{l}99 \\
99 \\
99 \\
98 \\
99\end{array}$ & $\begin{array}{l}230 \\
230 \\
230 \\
224 \\
230\end{array}$ & $\begin{array}{l}58 \\
58 \\
58 \\
56 \\
56\end{array}$ & $\begin{array}{l}685 \\
685 \\
685 \\
648 \\
648\end{array}$ & $\begin{array}{l}62 \\
58 \\
63 \\
53 \\
62\end{array}$ & $\begin{array}{l}792 \\
685 \\
833 \\
685 \\
792\end{array}$ \\
\hline Average & 99 & 228 & 57 & 670 & 60 & 757 \\
\hline $\begin{array}{l}\text { Tatal } \\
\text { Average }\end{array}$ & 98 & 223 & 55 & 634 & 60 & 783 \\
\hline
\end{tabular}

Powder wSpray Welding Surface Hardness

* EQ HV = Equivalent Vickers Hardness 
Table 43

\begin{tabular}{|c|c|c|c|c|c|c|}
\hline \multirow[b]{2}{*}{ Test No } & \multicolumn{2}{|c|}{ Grey Cast Iron } & \multicolumn{2}{|c|}{1 Layer Deposit } & \multicolumn{2}{|c|}{2 Layer Deposits } \\
\hline & $R b$ & ${ }^{*} E Q H V$ & R 6 & ${ }^{*} E Q H V$ & $R_{c}$ & EQ HV \\
\hline 1 & $\begin{array}{l}99 \\
99 \\
90 \\
99 \\
99\end{array}$ & $\begin{array}{l}230 \\
230 \\
2=4 \\
230 \\
230\end{array}$ & $\begin{array}{l}47 \\
30 \\
40 \\
47 \\
49\end{array}$ & $\begin{array}{l}481 \\
543 \\
513 \\
431 \\
513\end{array}$ & $\begin{array}{l}55 \\
55 \\
55 \\
55 \\
55 \\
55\end{array}$ & $\begin{array}{l}629 \\
629 \\
629 \\
608 \\
629\end{array}$ \\
\hline Average & 99 & 228 & 48 & 508 & 55 & 625 \\
\hline 2 & $\begin{array}{l}97 \\
96 \\
98 \\
98 \\
98\end{array}$ & $\begin{array}{l}218 \\
212 \\
224 \\
224 \\
224\end{array}$ & $\begin{array}{l}47 \\
47 \\
45 \\
47 \\
47\end{array}$ & $\begin{array}{l}481 \\
481 \\
454 \\
481 \\
481\end{array}$ & $\begin{array}{l}46 \\
46 \\
52 \\
46 \\
34\end{array}$ & $\begin{array}{l}467 \\
467 \\
570 \\
467 \\
339\end{array}$ \\
\hline Average & 97 & 220 & 46 & $4 ? 5$ & 44 & 462 \\
\hline 3 & $\begin{array}{l}97 \\
97 . \\
96 \\
98 \\
98\end{array}$ & $\begin{array}{l}218 \\
218 \\
212 \\
224 \\
224\end{array}$ & $\begin{array}{l}50 \\
49 \\
49 \\
45 \\
49\end{array}$ & $\begin{array}{l}543 \\
518 \\
518 \\
454 \\
518\end{array}$ & $\begin{array}{l}55 \\
55 \\
55 \\
54 \\
54\end{array}$ & $\begin{array}{l}629 \\
629 \\
629 \\
608 \\
608\end{array}$ \\
\hline Average & 97 & 219 & 48 & 510 & 54 & 620 \\
\hline 4 & $\begin{array}{l}98 \\
98 \\
98 \\
98 \\
98\end{array}$ & $\begin{array}{l}224 \\
224 \\
224 \\
224 \\
224\end{array}$ & $\begin{array}{l}39 \\
47 \\
53 \\
53 \\
53\end{array}$ & $\begin{array}{l}371 \\
481 \\
598 \\
598 \\
598\end{array}$ & $\begin{array}{l}54 \\
54 \\
52 \\
54 \\
54\end{array}$ & $\begin{array}{l}608 \\
608 \\
570 \\
608 \\
608\end{array}$ \\
\hline Average & 98 & 224 & 49 & 529 & 53 & 600 \\
\hline 5 & $\begin{array}{l}99 \\
99 \\
99 \\
98 \\
99\end{array}$ & $\begin{array}{l}230 \\
230 \\
230 \\
224 \\
230\end{array}$ & $\begin{array}{l}44 \\
44 \\
45 \\
45 \\
45\end{array}$ & $\begin{array}{l}441 \\
441 \\
454 \\
454 \\
454\end{array}$ & $\begin{array}{l}54 \\
52 \\
53 \\
55 \\
57\end{array}$ & $\begin{array}{l}608 \\
570 \\
598 \\
629 \\
666\end{array}$ \\
\hline Average & 99 & 228 & 44 & 448 & 54 & 614 \\
\hline $\begin{array}{c}\text { Total } \\
\text { Average }\end{array}$ & 98 & 223 & 47 & 494 & 52 & 584 \\
\hline
\end{tabular}


Table 44

\begin{tabular}{|c|c|c|c|c|c|c|}
\hline \multirow[b]{2}{*}{ Test No } & \multicolumn{2}{|c|}{ Grey Cast Iron } & \multicolumn{2}{|c|}{1 Layer Deposit } & \multicolumn{2}{|c|}{2 Layer Deposits } \\
\hline & $R b$ & ${ }^{*} E Q H V$ & $R c$ & EQ HV & $R c$ & EQ HV \\
\hline 1 & $\begin{array}{l}99 \\
99 \\
90 \\
99 \\
99\end{array}$ & $\begin{array}{l}230 \\
230 \\
234 \\
230 \\
230\end{array}$ & $\begin{array}{l}49 \\
49 \\
50 \\
50 \\
50\end{array}$ & $\begin{array}{l}518 \\
518 \\
543 \\
543 \\
543\end{array}$ & $\begin{array}{l}45 \\
55 \\
54 \\
55 \\
55\end{array}$ & $\begin{array}{l}513 \\
629 \\
600 \\
629 \\
629\end{array}$ \\
\hline Average & 99 & 228 & 49 & 533 & 53 & 602 \\
\hline 2 & $\begin{array}{l}97 \\
96 \\
98 \\
98 \\
98\end{array}$ & $\begin{array}{l}218 \\
212 \\
224 \\
224 \\
224\end{array}$ & $\begin{array}{l}49 \\
45 \\
45 \\
45 \\
44\end{array}$ & $\begin{array}{l}518 \\
454 \\
454 \\
454 \\
441\end{array}$ & $\begin{array}{l}50 \\
50 \\
52 \\
52 \\
52\end{array}$ & $\begin{array}{l}535 \\
535 \\
570 \\
570 \\
570\end{array}$ \\
\hline Average & 97 & 220 & 45 & 464 & 51 & 556 \\
\hline 3 & $\begin{array}{l}97 \\
97 . \\
96 \\
98 \\
98\end{array}$ & $\begin{array}{l}218 \\
218 \\
212 \\
224 \\
224\end{array}$ & $\begin{array}{l}44 \\
49 \\
45 \\
49 \\
44\end{array}$ & $\begin{array}{l}441 \\
518 \\
454 \\
518 \\
441\end{array}$ & $\begin{array}{l}54 \\
54 \\
54 \\
54 \\
54\end{array}$ & $\begin{array}{l}608 \\
608 \\
608 \\
608 \\
608\end{array}$ \\
\hline Average & 97 & 219 & 46 & 474 & 54 & 608 \\
\hline 4 & $\begin{array}{l}98 \\
98 \\
98 \\
98 \\
98\end{array}$ & $\begin{array}{l}224 \\
224 \\
224 \\
224 \\
224\end{array}$ & $\begin{array}{l}50 \\
54 \\
54 \\
52 \\
52\end{array}$ & $\begin{array}{l}543 \\
608 \\
603 \\
570 \\
570\end{array}$ & $\begin{array}{l}52 \\
48 \\
52 \\
52 \\
50\end{array}$ & $\begin{array}{l}570 \\
501 \\
570 \\
570 \\
535\end{array}$ \\
\hline Average & 98 & 224 & 52 & 530 & 51 & 549 \\
\hline 5 & $\begin{array}{l}99 \\
99 \\
99 \\
90 \\
99\end{array}$ & $\begin{array}{l}230 \\
230 \\
230 \\
224 \\
230\end{array}$ & $\begin{array}{l}49 \\
45 \\
45 \\
49 \\
49\end{array}$ & $\begin{array}{l}518 \\
454 \\
454 \\
518 \\
518\end{array}$ & $\begin{array}{l}49 \\
49 \\
50 \\
49 \\
49\end{array}$ & $\begin{array}{l}518 \\
518 \\
535 \\
518 \\
518\end{array}$ \\
\hline Average & 99 & $2 \approx 8$ & 47 & 492 & 49 & 521 \\
\hline $\begin{array}{c}\text { Total } \\
\text { Average } \\
\end{array}$ & 98 & 223 & 48 & 508 & 51 & 567 \\
\hline
\end{tabular}

Tungsten Inert Gas Welding Surface Hardness

*EQ HV= Equivalent Vickers Hardness 
Table 45

\begin{tabular}{|l|c|}
\hline $\begin{array}{c}\text { Average } \\
\text { Deprh mm }\end{array}$ & $\begin{array}{c}\text { Average } \\
\mathrm{HV}\end{array}$ \\
\hline 0.085 & 675 \\
0.140 & 742 \\
0.225 & 736 \\
0.327 & 719 \\
0.411 & 600 \\
0.431 & 473 \\
0.563 & 330 \\
0.679 & 265 \\
0.016 & 631 \\
1.035 & 224 \\
\hline
\end{tabular}

\section{Thermal Spraying 1 Layer Deposit Macro Hardness}

Table 46

\begin{tabular}{|l|c|}
\hline $\begin{array}{l}\text { Average } \\
\text { Depth m m }\end{array}$ & $\begin{array}{c}\text { Average } \\
\text { HV }\end{array}$ \\
\hline & \\
0.009 & 605 \\
0.140 & 030 \\
0.213 & $0 \% 1$ \\
0.334 & 700 \\
0.456 & $4 \% ?$ \\
0.540 & 304 \\
0.605 & 607 \\
0.393 & 264 \\
1.086 & 230 \\
1.410 & $c 20$ \\
\hline
\end{tabular}

Thermal Spraying 2 Layer Deposits Macro Hardness 


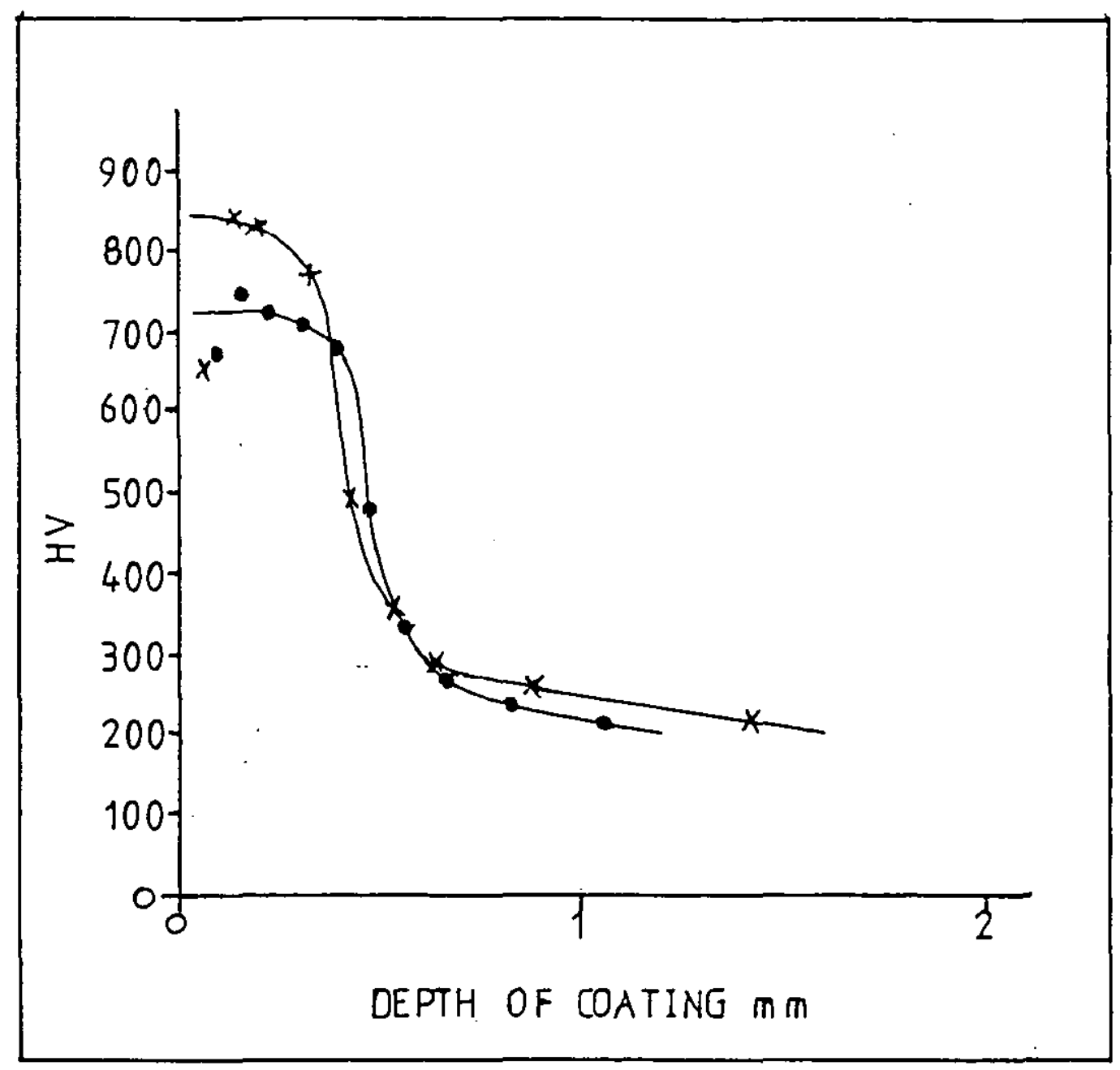

\section{FIG 4.26 HV Vs Depth of Coating Thermal Spraying Macro Hardness}

- = 1 Layer Deposit

$x=2$ Layer Deposits 
Table 47

\begin{tabular}{|l|l|}
\hline $\begin{array}{l}\text { Average } \\
\text { Depth mm }\end{array}$ & $\begin{array}{c}\text { Average } \\
\text { HV }\end{array}$ \\
\hline 0.157 & 700 \\
0.250 & 775 \\
0.407 & 751 \\
0.547 & 608 \\
0.695 & 626 \\
1.046 & 456 \\
1.203 & 408 \\
1.427 & 266 \\
1.549 & 250 \\
1.946 & 229 \\
\hline
\end{tabular}

Powder Spray Welding. 1 Layer Deposit. Macro Hardness

Table 48

\begin{tabular}{|l|l|}
\hline $\begin{array}{l}\text { Average } \\
\text { Depth m m }\end{array}$ & $\begin{array}{c}\text { Average } \\
\text { H.V }\end{array}$ \\
\hline & \\
0.136 & 848 \\
0.283 & 381 \\
0.393 & 797 \\
0.497 & 715 \\
0.756 & 635 \\
1.025 & 498 \\
1.253 & 423 \\
1.757 & 283 \\
2.335 & 252 \\
2.631 & 224 \\
\hline
\end{tabular}

Powder Spray Welding 2 Layer Deposits Macro Hardness 


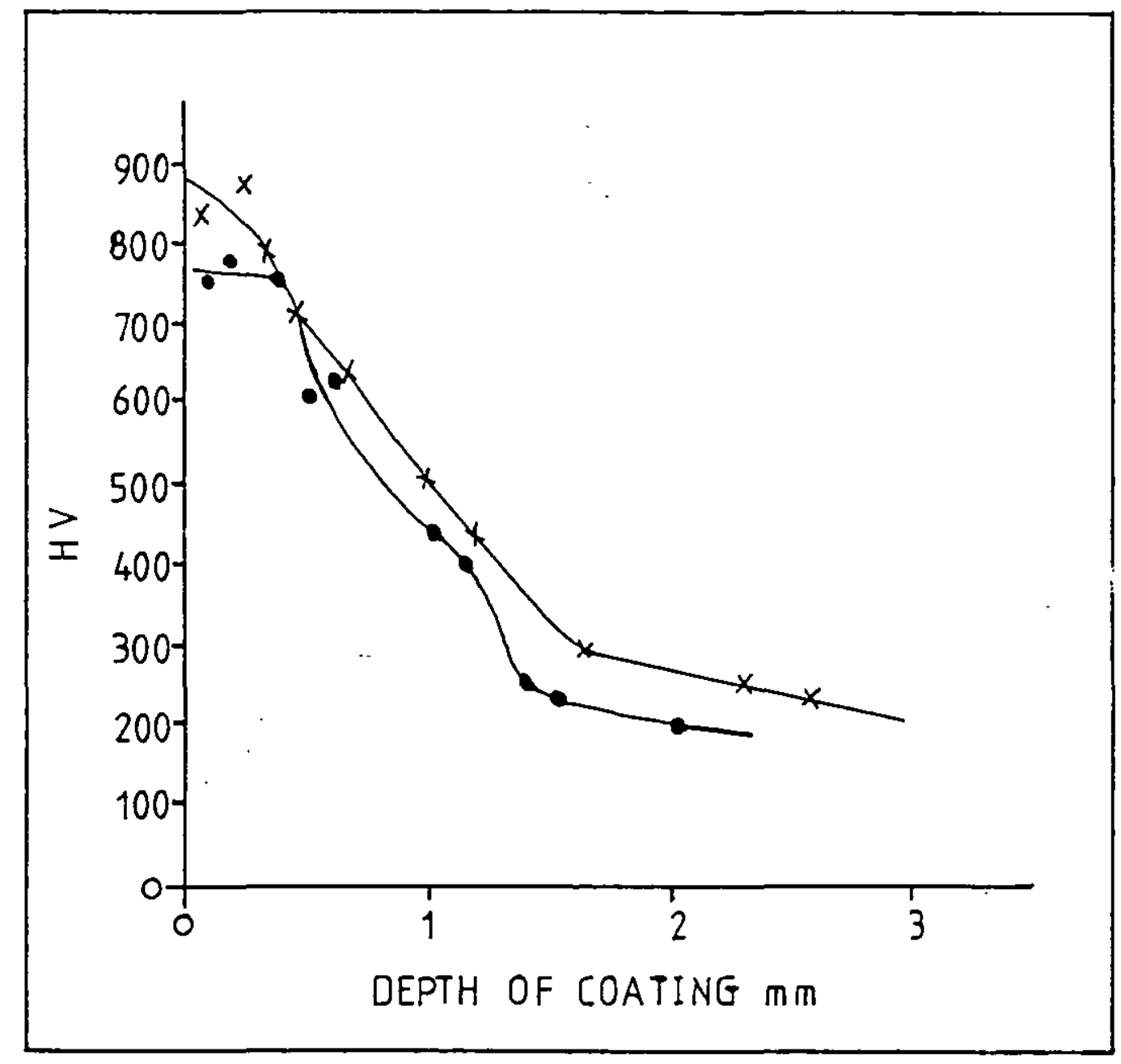

\section{FIG 4.27 HV Vs Depth of Coating Powder Spray Welding Macro Hardness}

$$
\begin{aligned}
& 0=1 \text { Layer Deposit } \\
& x=2 \text { Layer Deposits }
\end{aligned}
$$


Table 49

\begin{tabular}{|l|l|}
\hline $\begin{array}{l}\text { Average } \\
\text { Depth mm }\end{array}$ & $\begin{array}{c}\text { Average } \\
\text { HV }\end{array}$ \\
\hline & \\
0.213 & 530 \\
0.529 & 518 \\
0.538 & 311 \\
0.756 & 507 \\
1.188 & 468 \\
1.549 & 420 \\
1.843 & 344 \\
2.325 & 276 \\
3.048 & 248 \\
3.401 & 231 \\
\hline
\end{tabular}

Table 50

\begin{tabular}{|l|l|}
\hline $\begin{array}{l}\text { Average } \\
\text { Depth m m }\end{array}$ & $\begin{array}{c}\text { Average } \\
H . V\end{array}$ \\
\hline & \\
0.152 & 578 \\
0.269. & 554 \\
0.518 & 620 \\
0.353 & 658 \\
1.315 & 592 \\
1.843 & 534 \\
2.611 & 452 \\
2.949 & 354 \\
3.505 & 271 \\
4.166 & 236 \\
\hline
\end{tabular}




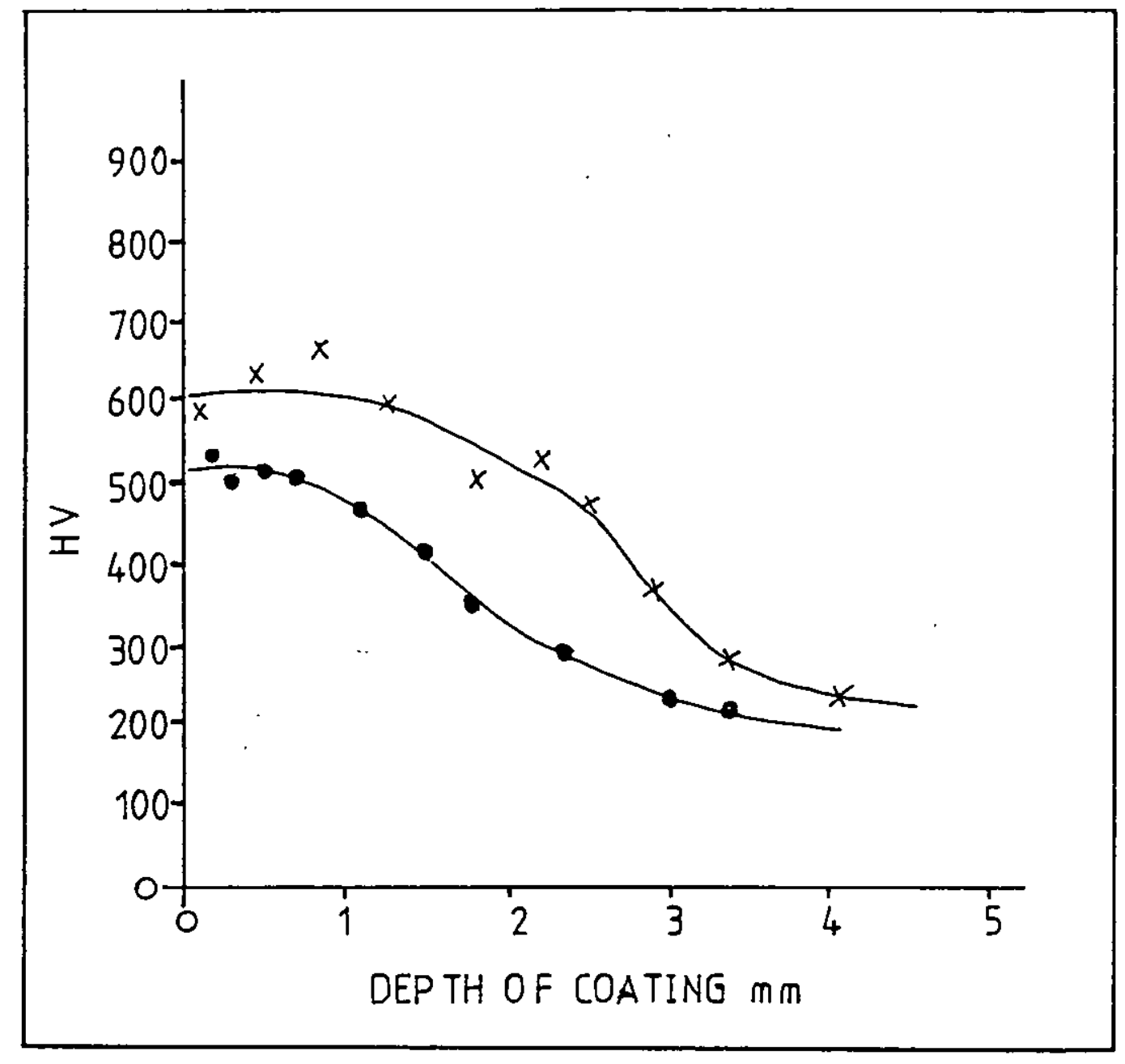

\section{FIG 4.28 HV Vs Depth of Coating Oxy-Acetylene Welding Macro Hardness}

- = 1 Layer Deposit

$x=2$ Layer Deposits 
Table 51

\begin{tabular}{|l|l|}
\hline $\begin{array}{l}\text { Average } \\
\text { Depth mm }\end{array}$ & $\begin{array}{c}\text { Average } \\
H V\end{array}$ \\
\hline & \\
0.210 & 309 \\
0.289 & 499 \\
0.642 & 409 \\
0.929 & 476 \\
2.378 & 440 \\
1.656 & 402 \\
1.964 & 385 \\
2.449 & 290 \\
2.316 & 237 \\
3.149 & 222 \\
\hline
\end{tabular}

Tungsten Inert Gas. 1 Layer Deposit. Macro Hardness

Table 52

\begin{tabular}{|l|l|}
\hline $\begin{array}{l}\text { Average } \\
\text { Depth mm }\end{array}$ & $\begin{array}{c}\text { Average } \\
\text { H.V }\end{array}$ \\
\hline & \\
0.192 & 011 \\
$0.340 \%$ & 599 \\
0.741 & 574 \\
1.137 & 558 \\
1.630 & 523 \\
2.221 & 467 \\
2.667 & 365 \\
3.047 & 276 \\
3.454 & 242 \\
4.013 & 224 \\
\hline
\end{tabular}

Tungsten Inert Gas 2 Layer Deposits Macro Hardness 


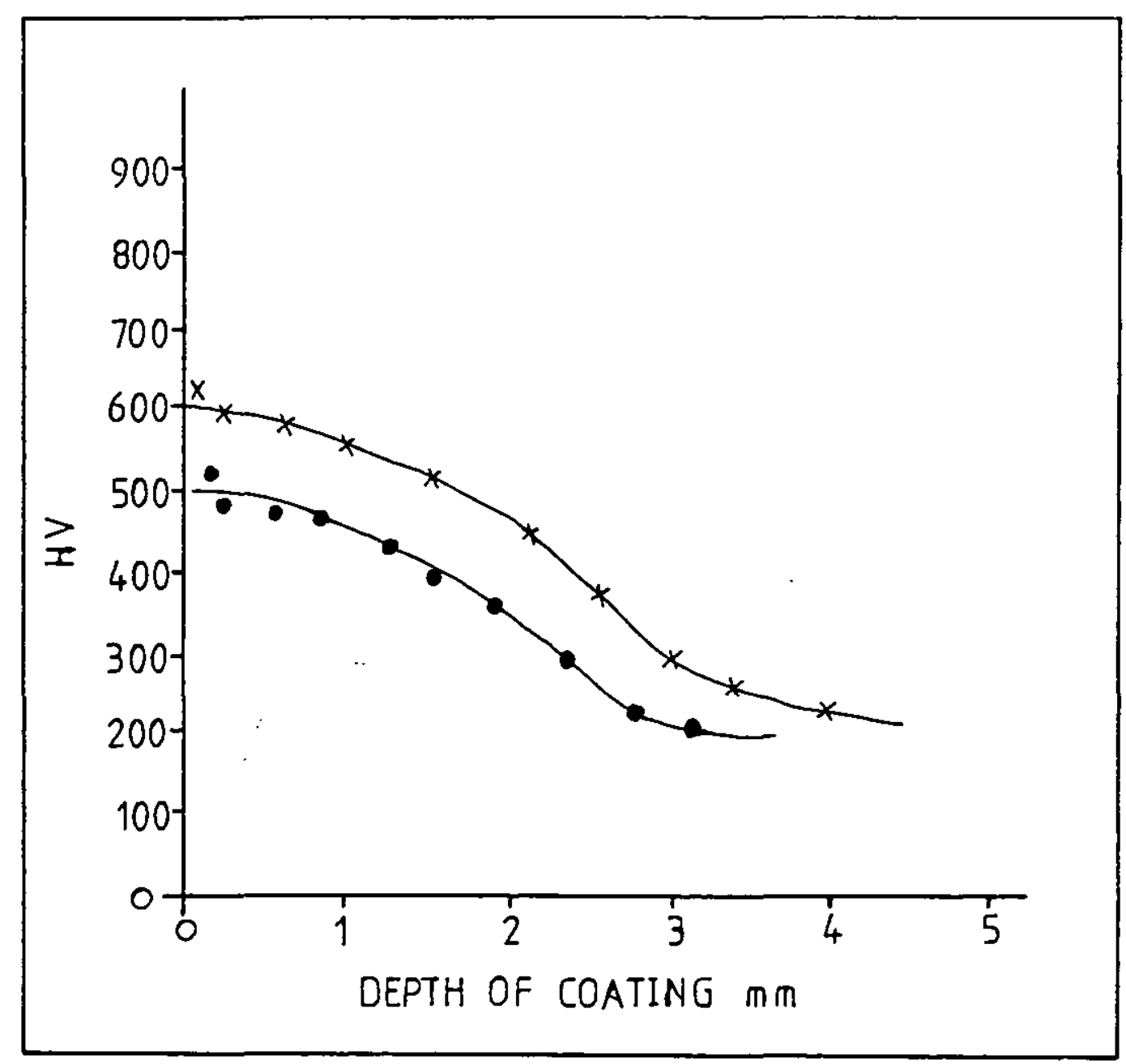

FIG 4.29 HV Vs Depth of Cocting

Iungsten Inert Gas Welding Macro Hardness

- = 1 Layer Deposit

$x=2$ Layer Deposits 
Tabie 53

\begin{tabular}{|c|c|c|c|c|}
\hline \multirow{2}{*}{ Process. } & \multicolumn{2}{|c|}{1 Layer Deposits } & \multicolumn{2}{|c|}{2 Layer Deposits. } \\
\hline & Interface & Alloy & Interface & Alloy \\
\hline $\begin{array}{l}\text { Thermal } \\
\text { Spraying }\end{array}$ & $0.009 \%$ & $52 \%-56 \%$ & $0.009 \%$ & $78 \%$ \\
\hline $\begin{array}{c}\text { Powder Spray } \\
\text { Welding }\end{array}$ & $0.009 \%$ & $53 \%$ & $0.009 \%$ & $77 \%$ \\
\hline $\begin{array}{c}\text { Oxy-acetylene } \\
\text { ielding }\end{array}$ & $0.0 z \%$ & $43 \%-48 \%$ & $0.02 \%$ & $53 \%-58 \%$ \\
\hline TIG & $0.04 \%$ & $30 \%-44 \%$ & $0.04 \%$ & $49 \%-53 \%$ \\
\hline
\end{tabular}

Electron Probe Microanalysis (EPMA)

Aporoximate Percentages $\mathrm{Ni}$

Table 54

\begin{tabular}{|c|c|c||c|c|}
\hline \multirow{2}{*}{ Process } & \multicolumn{2}{|c|}{1 Layer Deposits } & \multicolumn{2}{c|}{2 Layer Deposits. } \\
\cline { 2 - 3 } \cline { 5 - 6 } $\begin{array}{c}\text { Interiace } \\
\text { Spraying }\end{array}$ & 2 Alloy & & Interface & Alloy \\
\hline $\begin{array}{c}\text { Powder Spray } \\
\text { Welding }\end{array}$ & Zero & $5 \%-14 \%$ & $2 \%$ & $13 \%-17 \%$ \\
\hline $\begin{array}{c}\text { Oxy-acetylene } \\
\text { Welding }\end{array}$ & $1 \%$ & $4 \%-11 \%$ & $2 \%$ & $11 \%-20 \%$ \\
\hline TIG & $2 \%$ & $3 \%-7 \%$ & $2 \%$ & $4 \%-11 \%$ \\
\hline
\end{tabular}

Electron Probe Hicroanalysis (EPMA)

Approximate Percentages Cr 
Table 52

\begin{tabular}{|c|c|c|c|c|}
\hline \multirow{2}{*}{ Process } & \multicolumn{2}{|c|}{1 Layer jejosits } & \multicolumn{2}{c|}{ 2 Layer Deposits } \\
\cline { 2 - 5 } & Interface & Alloy & Interiace & Alloy \\
\hline $\begin{array}{c}\text { Thermal } \\
\text { Spraying }\end{array}$ & $1 \%$ & $1 \%$ & $1 \%$ & $2 \%$ \\
\hline $\begin{array}{c}\text { Powder Spray } \\
\text { Velding }\end{array}$ & $0.009 \%$ & $1 \%$ & $0.009 \%$ & $2 \%$ \\
\hline $\begin{array}{c}\text { Oxy-acetjlene } \\
\text { velding }\end{array}$ & $0.000 \%$ & $1 \%$ & $0.008 \%$ & $2 \%$ \\
\hline TIG & $1 \%$ & $1 \%$ & $1 \%$ & $2 \%$ \\
\hline
\end{tabular}

Electron Probe Microanalysis (EPMA)

Anoroximate Percentages Si

Taile 56

\begin{tabular}{|c|c|c|c|c|}
\hline \multirow{2}{*}{ Process } & \multicolumn{2}{|c|}{ I Layer Deposits } & \multicolumn{2}{|c|}{2 Layer Deposits } \\
\cline { 2 - 3 } \cline { 5 - 5 } & Interface & Alloy & Interface & Alloy \\
\hline $\begin{array}{c}\text { Thermal } \\
\text { Spraying }\end{array}$ & $4 \%$ & $4 \%$ & $4 \%$ & $3 \%$ \\
\hline $\begin{array}{c}\text { Powder Spray } \\
\text { Welding }\end{array}$ & $5 \%$ & $4 \%$ & $4 \%$ & $3 \%$ \\
\hline $\begin{array}{c}\text { Oxy-acetylene } \\
\text { Welding }\end{array}$ & $10 \%$ & $8 \%$ & $6 \%$ & $5 \%$ \\
\hline TIG & $17 \%$ & $11 \%$ & $10 \%$ & $8 \%$ \\
\hline
\end{tabular}

Electron Proie Vicroanalysis (EPMA)

Approximate Percentages Fe 
(a)

(b)

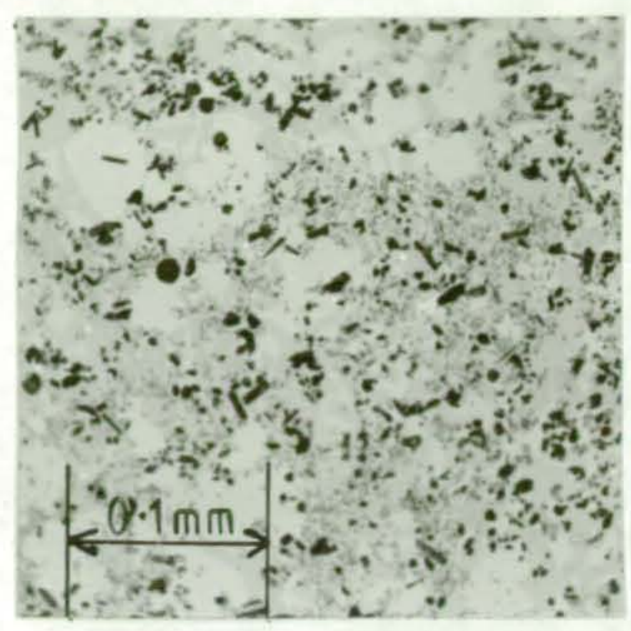

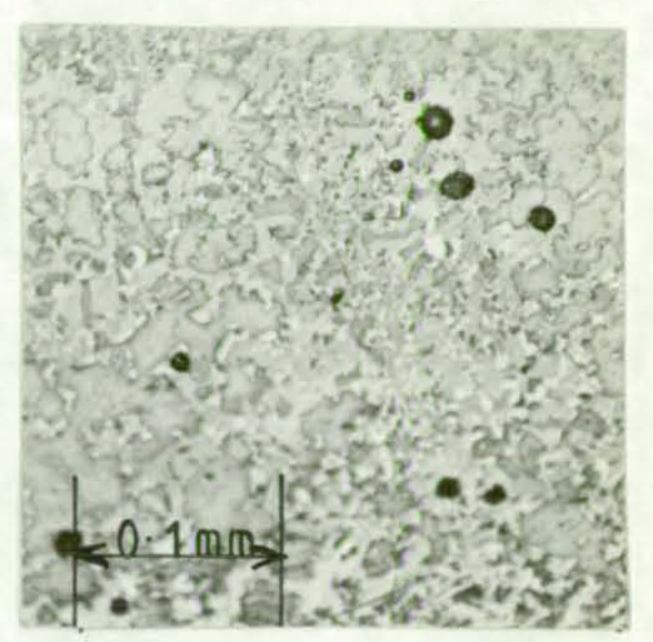

PLATE 4.1 Thermal Spraying Microstrucrure

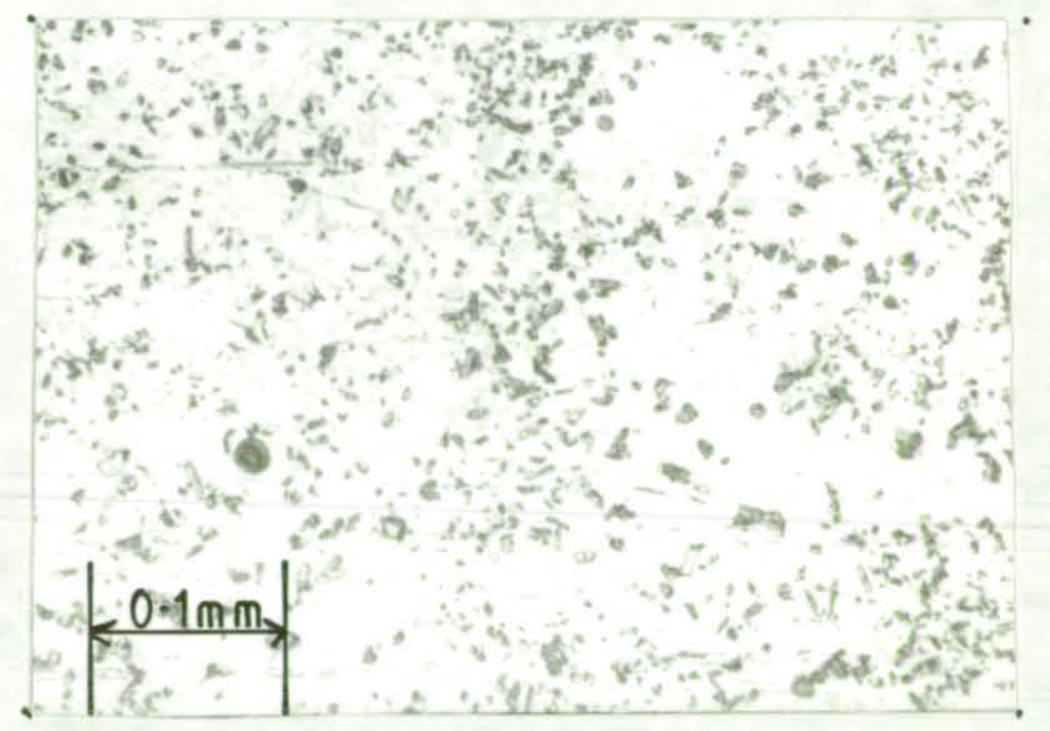

PLATE 4.2 Thermal Spraying Microstructure 

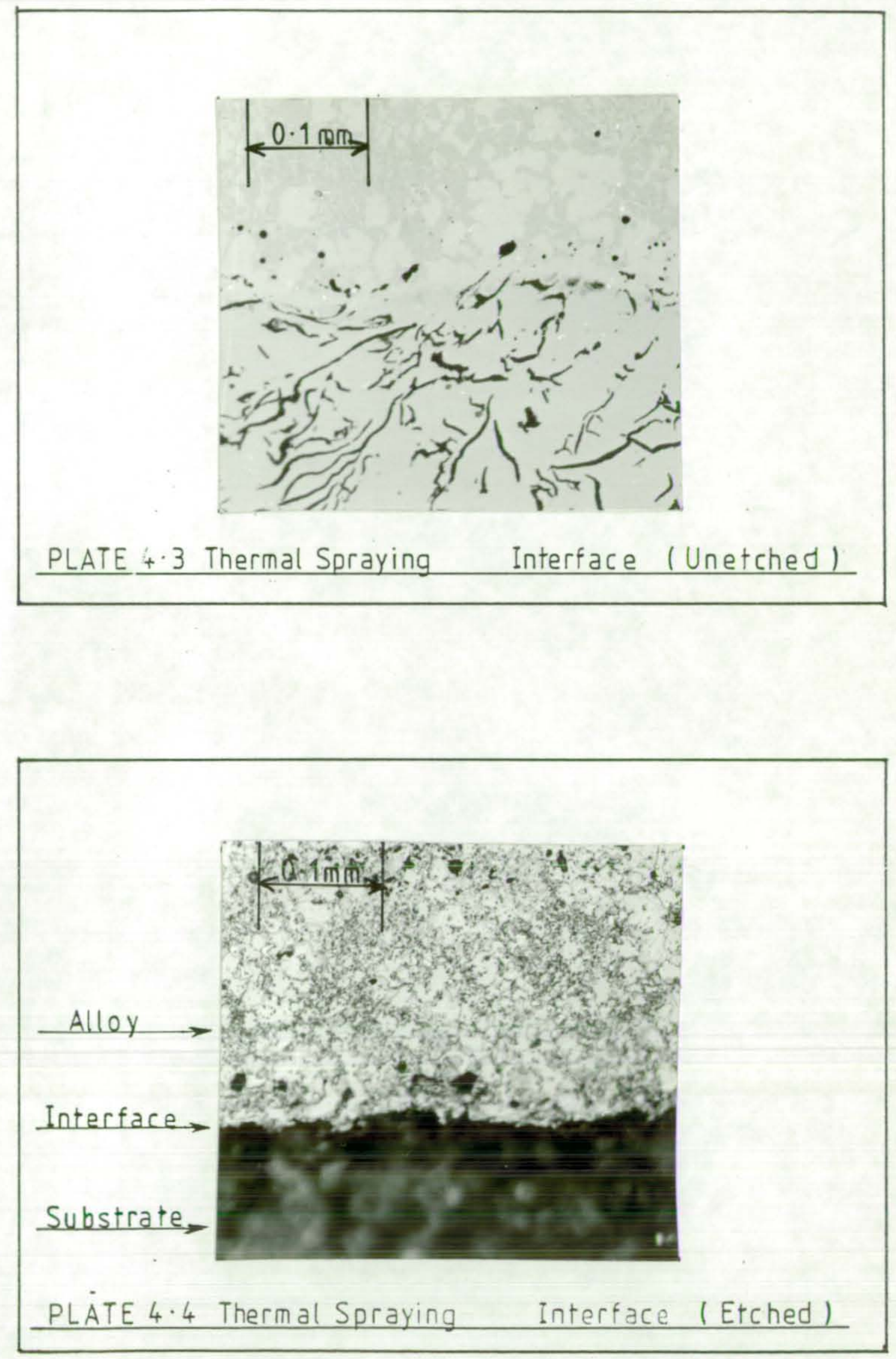
(a)

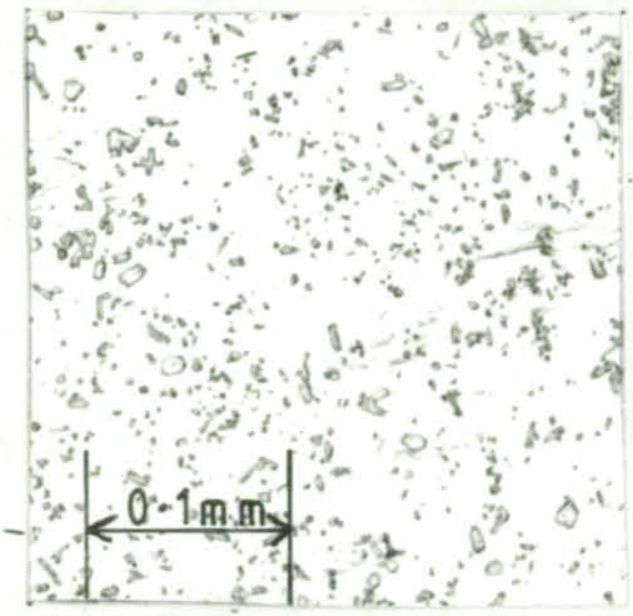

(b)

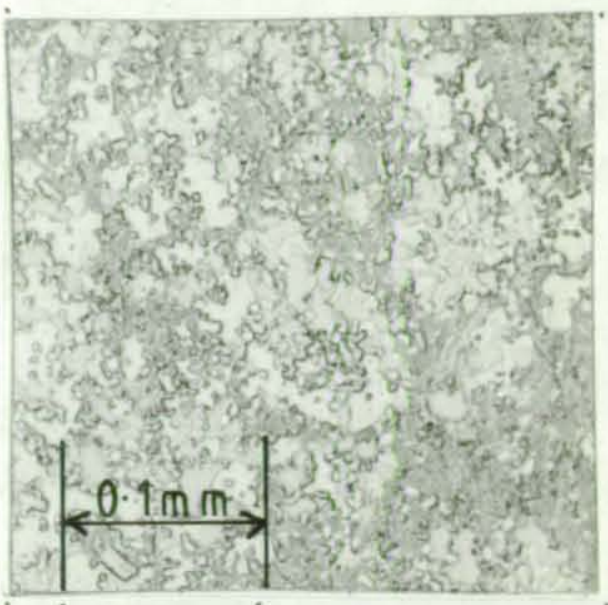

PLATE 4.5 Powder Spray Welding Microstructure

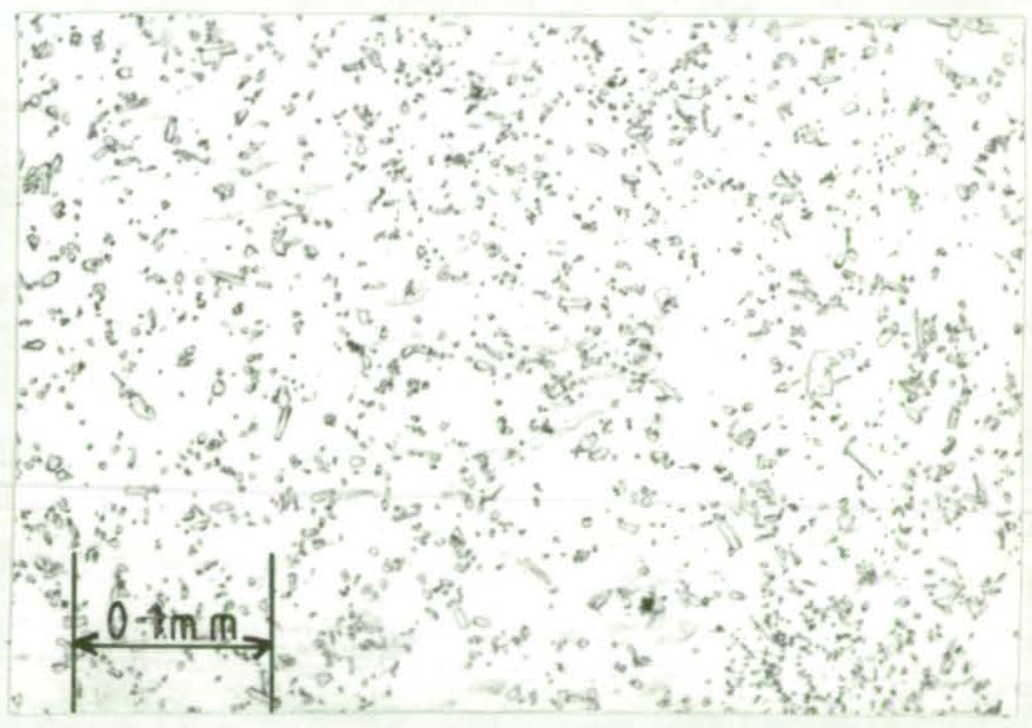

PLATE 4.6 Powder Spray Welding Microstructure 


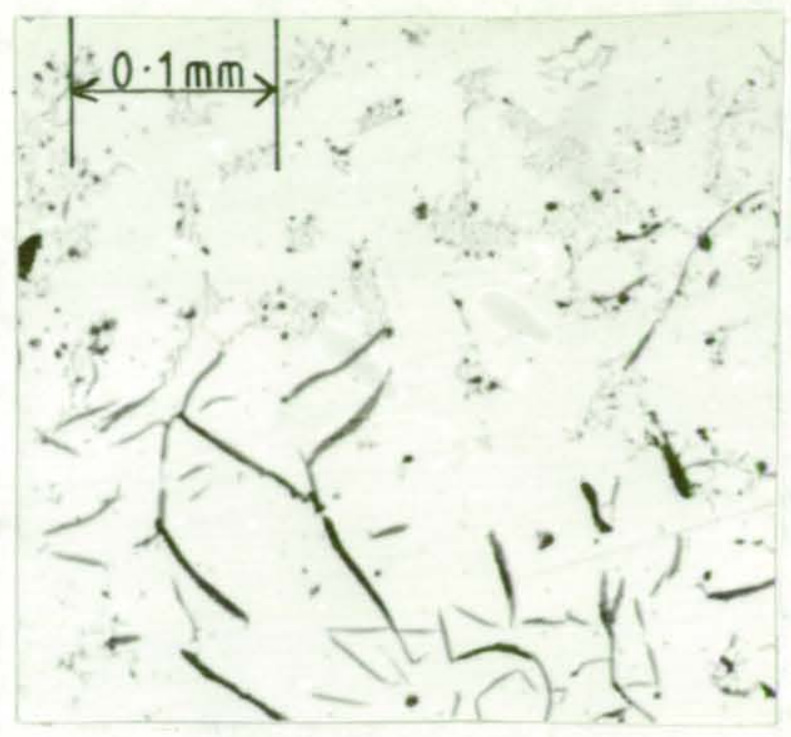

FLATE 4.7 Powder Spray Welding Interface (Unetched)

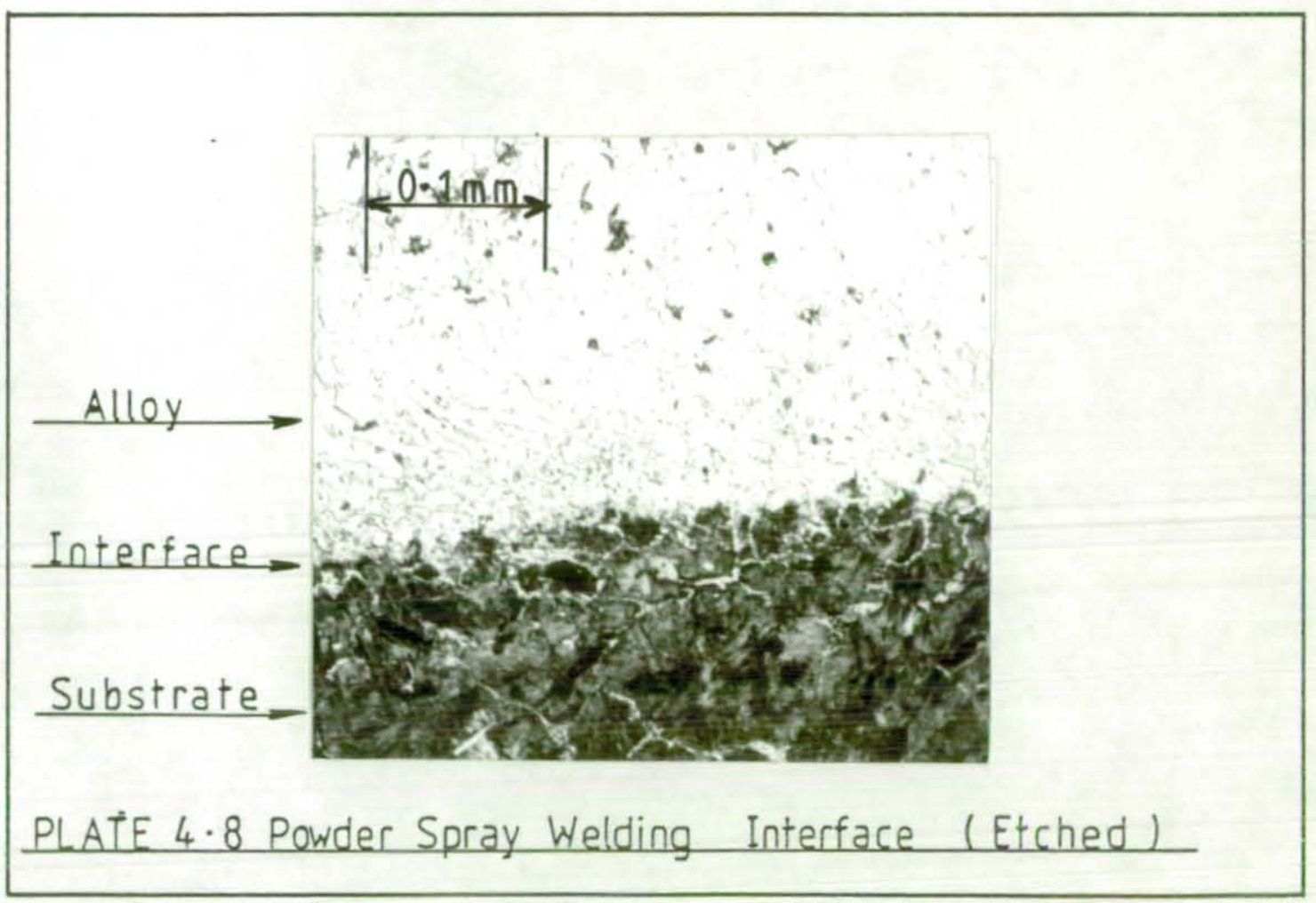




\section{(a)}

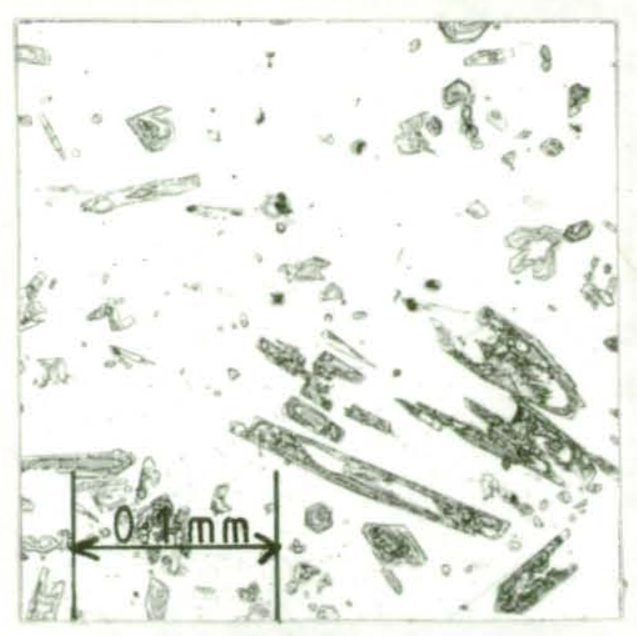

(b)

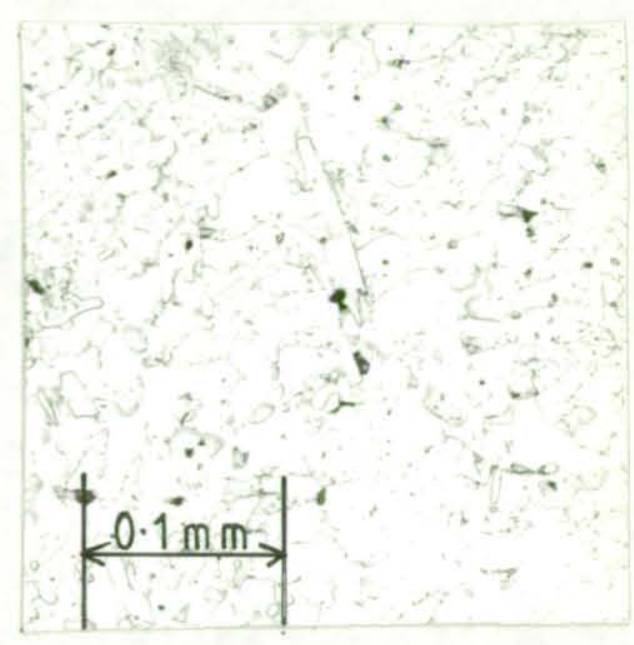

PLATE 4.9 Oxy-Acetylene Welding Microstructure

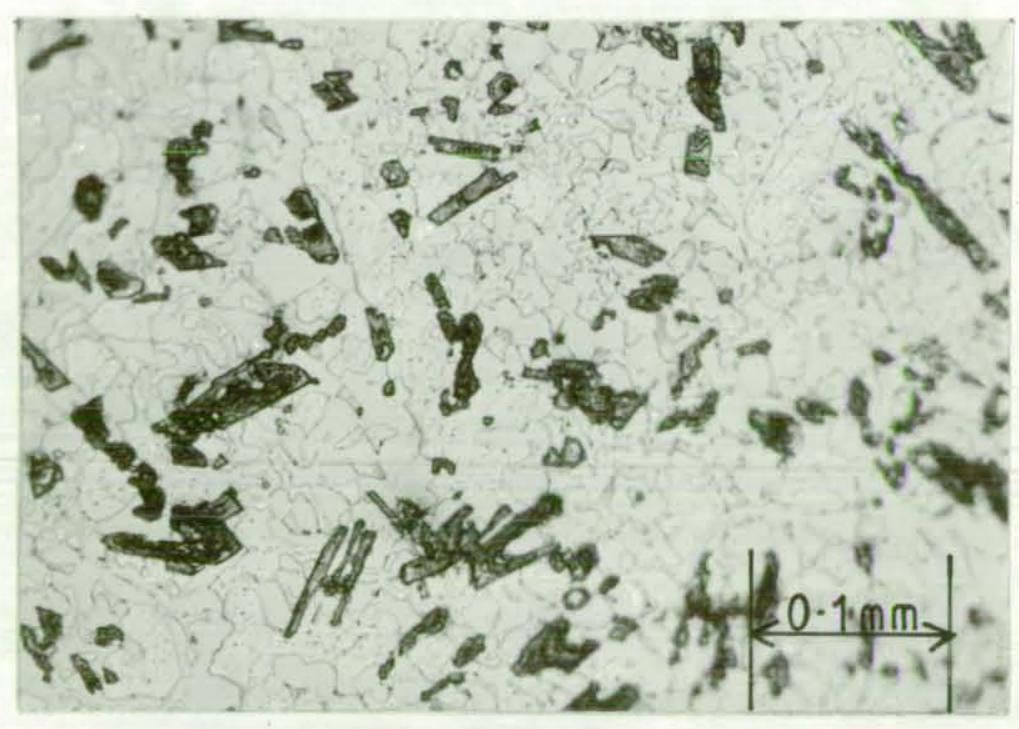

PLATE 4.10 Oxy - Acetylene Welding Microstructure 


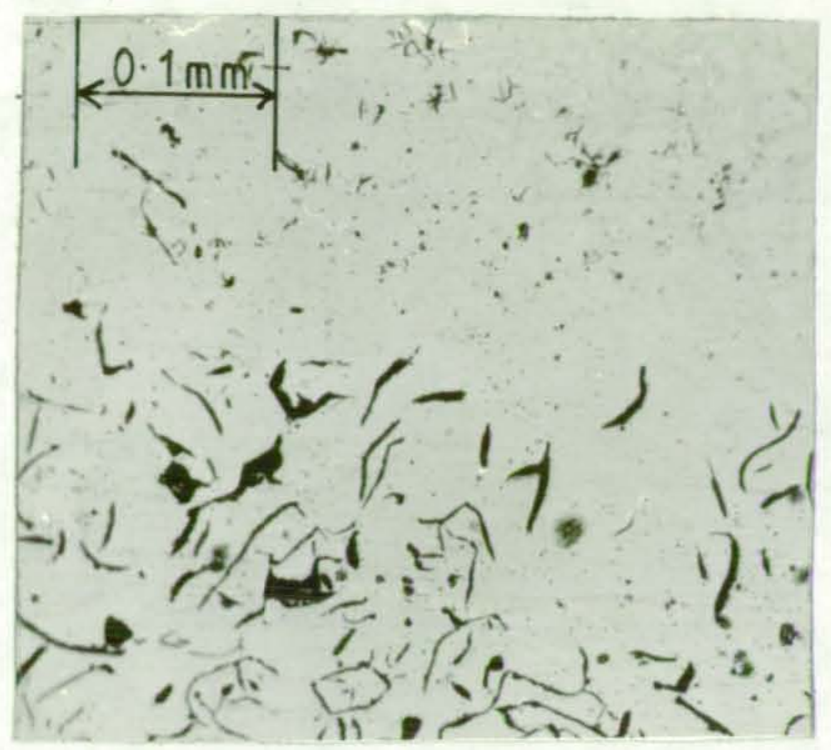

PLATE 4.11 Oxy-Acetylene Welding Interface (Unetched)

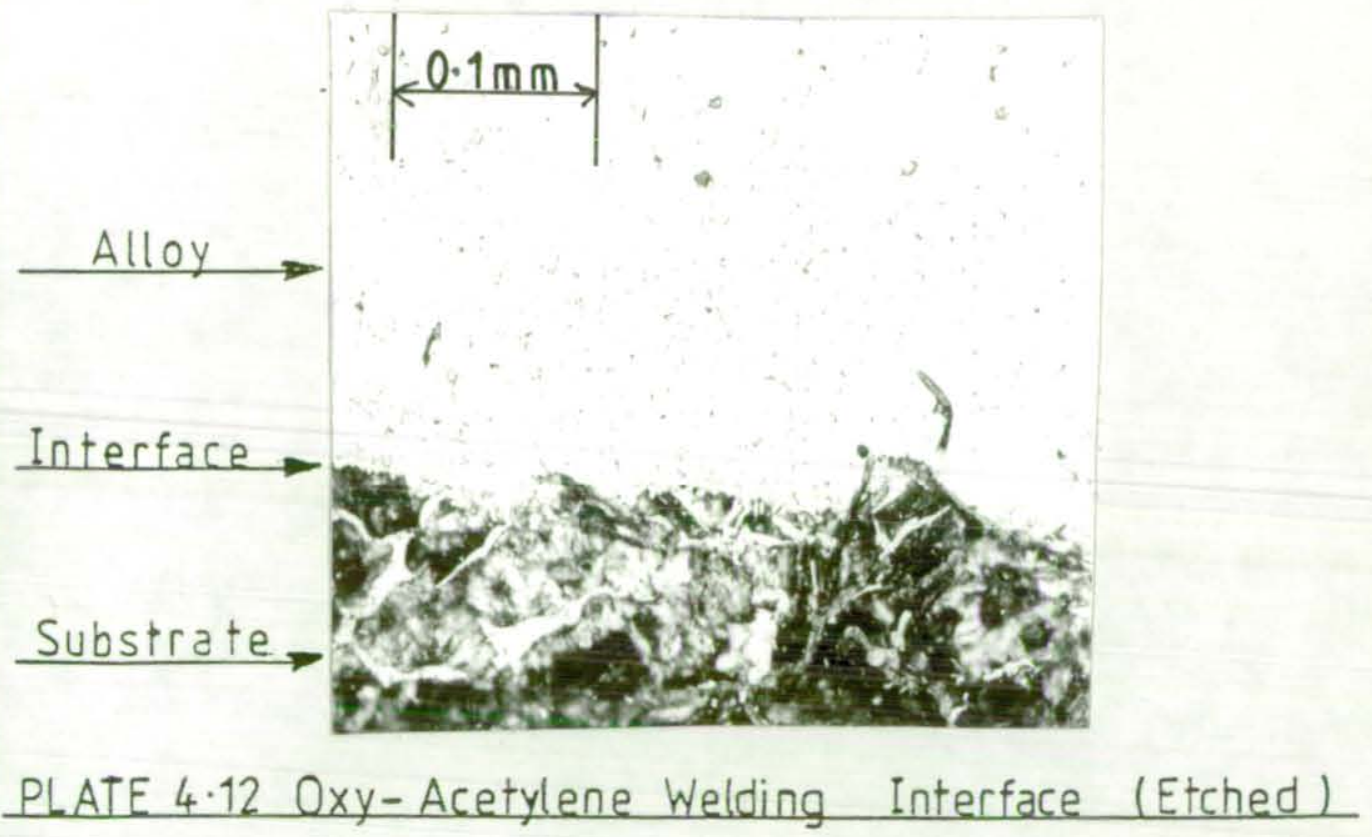


( a )

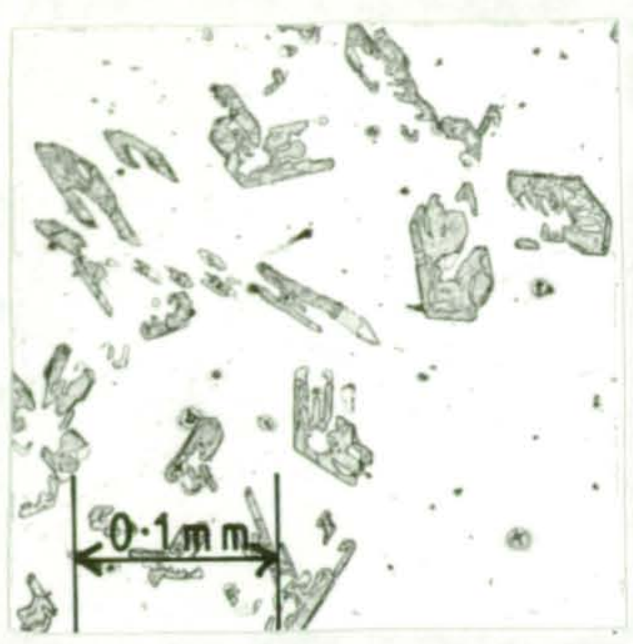

(b)

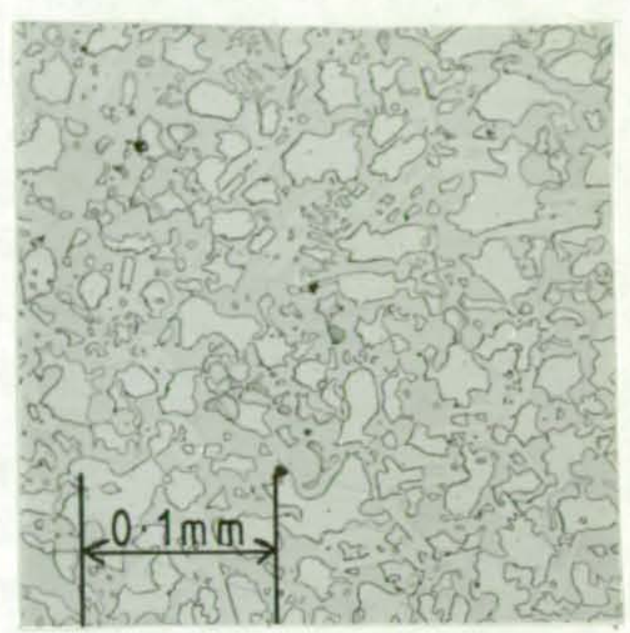

PLATE 4.13 Tungsten Inert Gas Welsing Microstructure

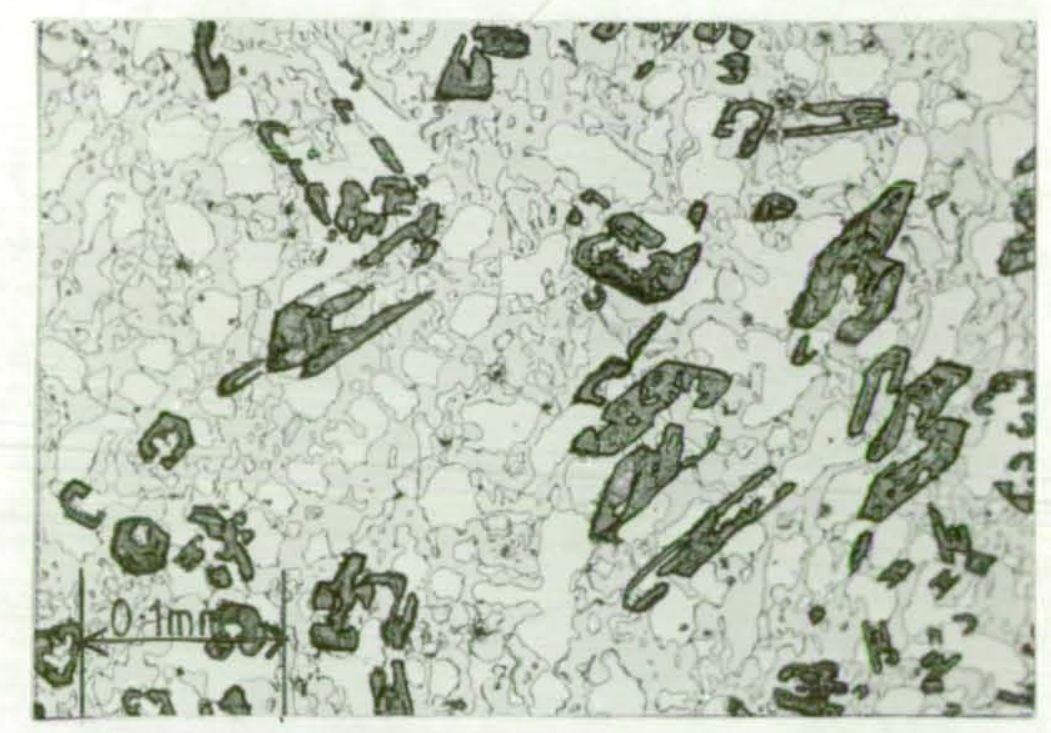

PLATE 4-14 Tungsten Inert Gas Welding Microstructure 

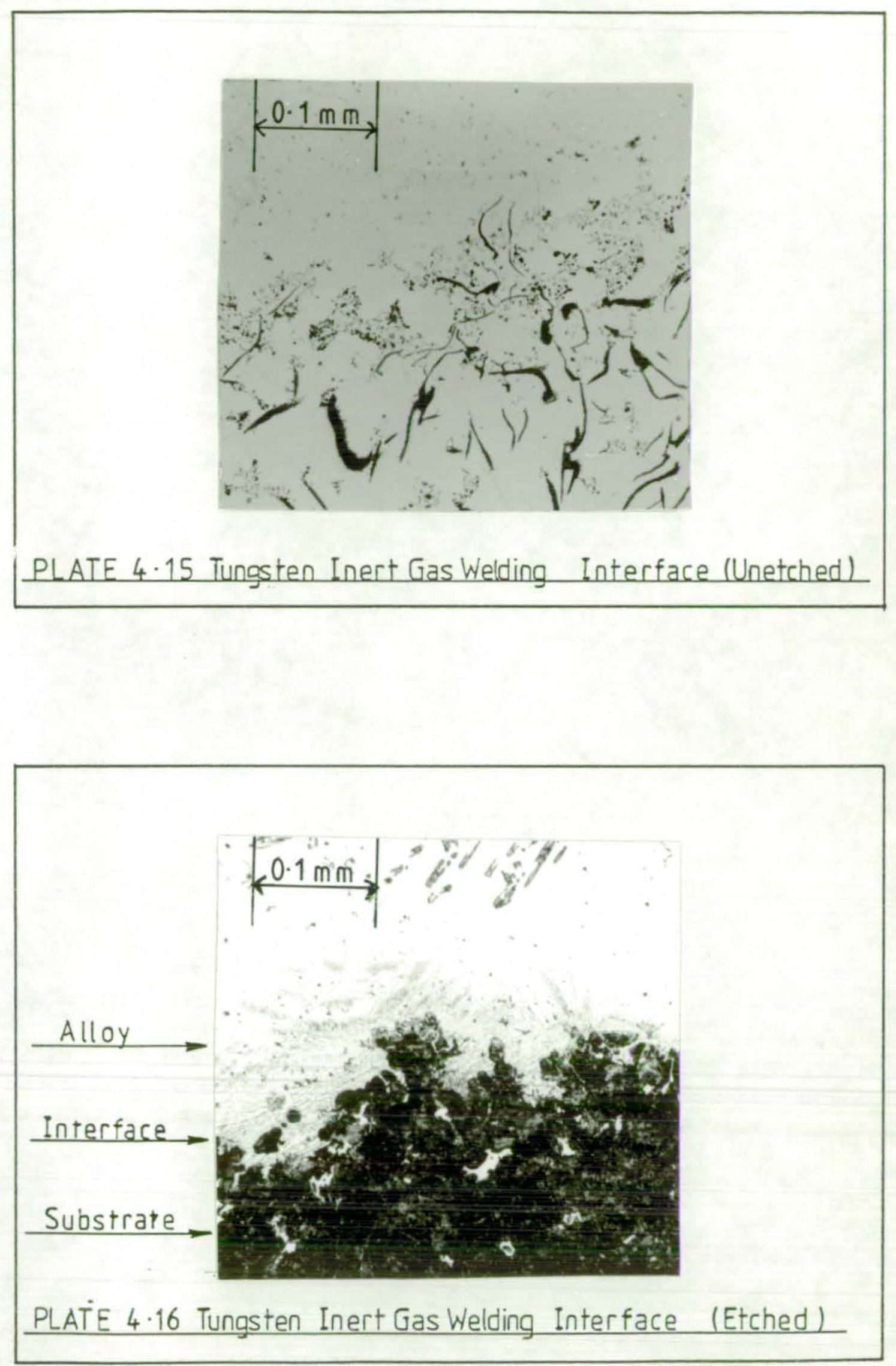
CHAPTER 5

DISCUSSION OF RESULTS 


\section{DISCUSSION OF THE RESULTS}

\subsection{Abrasive :̈ear Testing}

The abrasive wear tests were carried out according to the standard procedures outlined in section 3.1. By conducting. tests at different loads for different durations, light and heavy abrasion conditions could be simulated and the performance of the coatings under these conditions could be assessed.

In this section the results are discussed in the sequence that they were presented in the results section. Eacin group of results is first discussed independently but the correlation between the results from the different tests is drawn out witnin the Discussion Summary section.

\subsubsection{Control Specimens}

Figure 4.1 snows the relationship between wear volume, wear load and wear test duration (number of scratches). The general form of the graphs is as expected in that wear volume increases both with load and test duration.

Although the wear volume increases with increasing load and numier of scratches, as expected, there is proportionally more near at the lower loads of $2.5 \mathrm{~kg}$ and $5 \mathrm{~kg}$ than at the higher 10 ad $10 \mathrm{~kg}$, for the 10,50 and 100 scratch tests. However, in the case oi the 500 scratch test the wear volume increases with increasing load to a much greater extent.

This wear pattern is apparently caused by the formation of a hard-layer. According to Eyre and Vilson (74), during running-in linder both unlubricated and lubricated conditions, a hard layerimay be formed on the surface as a result of surface 
interaction. These layers have been referred to as "hard", "winte" or "non-etching" and have been reported to form in most ferrous retals under a wide range of conditions. During runnings-in tine wear rate is initially high with a severe form or wear, anc surface topographical and microstructural changes take place, producing a surface-hardened layer Wich evertualiy becomes. covered with an oxide layer as the equilibrium mild wear condition is estabisined. A transition from a mild form oi viear to a severe form of wear takes place suddenly at some critical load or sliding speed and the wear rate increases by at least an order of magnitude. At the higher load the wear rate shows a marked increase with a change from mild to severe wear and then decreases again as it crosses back from the severe to mild wear region.

\section{1 .2 jardiaced Surfaces}

When the wear test results for the coated surfaces are compared with those for the cast iron substrate, Figures 4.2 to 4.25, it can be seen that the wear volume is narkedily reduced for the same loads and test durations. The wear test results for the four hardfacing processes show consistent similarities in that for every process the wear vollume increases with both increasing load and test duration. Furthermore, tine one layer coatin̈̈s consistently demonstrated a nigher level of wear than the two layer coatings.

The wear test data for each process has been tabulated in a way which aids comparison. In each table the average wear volumes for: the 1 layer deposit (B) relative to the cast iron substrate (A); the 2 layer deposit (C) relative to the cast iron substrate (A); and the 2 layer deposit (C) relative to the 1 layer deposit (B) are presented as follows: 
Table 57 : Thermal Spraying

Table 58 : Powder spray :eldino

Table 59: Oxy-acetylene :ielding

Table 60 : Tungsten Inert Gas Helding

Table 57

\begin{tabular}{|c|c|c|c|c|c|c|}
\hline \multicolumn{4}{|c|}{ Average Hear Voiume mu } & \multicolumn{3}{|c|}{ Pelative Percentage “iear } \\
\hline Loaci $\ddot{x}$ & A & $\begin{array}{c}B \\
1 \text { Layer }\end{array}$ & $\begin{array}{c}\text { C } \\
2 \text { Layer }\end{array}$ & $\begin{array}{l}\equiv \text { to A } \\
\Xi \div \mathrm{A} \\
\approx \mathrm{i} 00 \%\end{array}$ & $\begin{array}{l}C \text { to } A \\
C \div A \\
x i 00 \%\end{array}$ & $\begin{array}{l}C \text { io } B \\
c \div 3 \\
x i 00 ;\end{array}$ \\
\hline 2.5 & 1.915 & 0.111 & 0.040 & 5.8 & 2 & 36.0 \\
\hline 5 & 3.210 & 0.264 & 0.137 & 8.2 & $4 \cdot 3$ & 52.4 \\
\hline 10 & $5.4 う \bar{~}$ & 0.395 & 0.135 & 7.3 & 2.5 & 34.2 \\
\hline \multicolumn{7}{|c|}{10 Scratches } \\
\hline 2.5 & 3.050 & 0.459 & 0.359 & 15 & 11.7 & $78 . \bar{c}$ \\
\hline 5 & 5.211 & 0.655 & 0.577 & 12.5 & 11 & 88 \\
\hline 10 & 7.926 & 1.039 & 0.826 & 12.6 & 10.4 & $29-4$ \\
\hline \multicolumn{7}{|c|}{50 Scratches } \\
\hline $2 . .5$ & 4.360 & 0.487 & $0.37 z$ & $1 I$ & 8.5 & 76.3 \\
\hline j & 6.501 & 0.817 & 0.652 & $1 \ddot{z} \cdot 9$ & $10 . \overline{3}$ & 79.8 \\
\hline 10 & $\ddot{y} \cdot 450$ & 1.104 & 0.966 & 11.6 & 10.2 & 87.5 \\
\hline \multicolumn{7}{|c|}{100 Scratches } \\
\hline 2.5 & 6.132 & 1.591 & 1.121 & 25.9 & 18.2 & $70 \cdot 4$ \\
\hline 5 & 9.130 & 2.647 & 1.870 & 28.9 & 20.4 & 70.6 \\
\hline 10 & $1 \equiv .993$ & 3.758 & 2.863 & 23.4 & 17.9 & 76.3 \\
\hline \multicolumn{7}{|c|}{500 Scratches } \\
\hline
\end{tabular}


Tabie 58

\begin{tabular}{|c|c|c|c|c|c|c|}
\hline \multicolumn{4}{|c|}{ Averäe Wear Volune mi } & \multicolumn{3}{|c|}{ Eiative Percentage Hear } \\
\hline \multirow{2}{*}{ Loaci $\mathrm{Xz}$} & A & $\bar{s}$ & $\mathrm{C}$ & $\equiv$ to $\mathrm{A}$. & $C$ to $A$ & $C$ to $B$ \\
\hline & Cast Iror. & I Iayer & ¿ Layer & $\begin{array}{l}\bar{D} \div f_{2} \\
x \quad 100,:\end{array}$ & $\begin{array}{l}c \div \mathrm{A} \\
x \dot{\mathrm{i}} 00 \%\end{array}$ & $\begin{array}{l}C \div \bar{B} \\
x \quad 100,\end{array}$ \\
\hline 2.5 & 1.015 & 0.157 & 0.030 & 8.1 & 2 & $24 \cdot 2$ \\
\hline 5 & 3.210 & $c .296$ & 0.146 & 9.2 & $4 \cdot .5$ & $49 \cdot 3$ \\
\hline 10 & $5.4 \bar{z}$ & 0.560 & 0.273 & 10.4 & 5 & 48 \\
\hline \multicolumn{7}{|c|}{10 Scratches } \\
\hline z. 5. & 5.050 & 0.321 & 0.310 & 10.5 & 10.1 & 96.5 \\
\hline 5 & 5.211 & 0.579 & 0.570 & 11 & 10.9 & 98.4 \\
\hline 10 & 7.926 & 1.065 & 0.881 & 13.4 & 11 & 82.7 \\
\hline \multicolumn{7}{|c|}{50 scratches } \\
\hline 2.5 & 4.360 & 0.410 & 0.305 & 9.4 & 6.8 & 74.3 \\
\hline 5 & 6.301 & 0.627 & 0.559 & 9.9 & 3.8 & 89 \\
\hline 10 & $y .450$ & 1.064 & 0.955 & 11.2 & 10.1 & 89.7 \\
\hline \multicolumn{7}{|c|}{100 Scratches } \\
\hline 2.5 & $6.13 \overline{2}$ & 1.453 & 0.611 & $\ddot{<3.6}$ & 9.9 & 42 \\
\hline 5 & 4.130 & $\dot{c} .090$ & 0.918 & 22.8 & 10 & 43.9 \\
\hline 10 & 15.945 & 3.439 & 1.494 & 21.5 & 8.3 & $43 . \div$ \\
\hline \multicolumn{7}{|c|}{200 Scratches } \\
\hline
\end{tabular}




\begin{tabular}{|c|c|c|c|c|c|c|}
\hline \multicolumn{4}{|c|}{ Averāe ::ear Vuilume $\mathrm{mm}^{j}$} & \multicolumn{3}{|c|}{ Eejative Percentage l:ear } \\
\hline \multirow{2}{*}{ Load KE } & A & $E$ & $i$ & $\equiv$ ¿ $\mathrm{A}$ & $C$ to $A$ & $c$ to $\overline{3}$ \\
\hline & vast Iron & i Lâyer & $\hat{\epsilon} i \hat{a} j \in r$ & $\begin{array}{llc}B & \div & A \\
x & 100,0\end{array}$ & 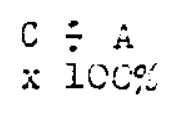 & $\begin{array}{l}i \div \bar{E} \\
x \dot{i} 00 \%\end{array}$ \\
\hline 2.5 & 1.915 & 0.259 & 0.177 & 13.5 & 9.2 & 60.3 \\
\hline 5 & 3.210 & 0.535 & $0.2 \div \overline{1}$ & $1 \doteqdot .6$ & 7.6 & 45.7 \\
\hline 10 & $5 . \div 52$ & $0.76 \dot{c}$ & $0 . \div 3$ & 13.9 & 7.9 & 56.8 \\
\hline \multicolumn{7}{|c|}{10 Scratches } \\
\hline 2.5 & 3.050 & $0.42 \div 6$ & 0.277 & 15.9 & 9 & 65 \\
\hline 5 & $j .21 I$ & 0.742 & 0.595 & $14 \cdot 2$ & 11.4 & $8 C$ \\
\hline 10 & 7.926 & 1.089 & 1.110 & 13.7 & 14 & 101.9 \\
\hline \multicolumn{7}{|c|}{20 scratches } \\
\hline 2.5 & 4.360 & $0.6,1$ & 0.615 & 15.8 & 14.1 & 89 \\
\hline 5 & 6.301 & 0.976 & 0.820 & 15.4 & 13 & 84 \\
\hline 10 & 9.450 & 1.518 & 1.459 & 16 & 15.4 & 96.1 \\
\hline \multicolumn{7}{|c|}{100 scratches } \\
\hline 2.5 & 6.132 & $1.470^{\circ}$ & 0.913 & 24 & $14 \cdot 8$ & 64 \\
\hline 5 & $\dot{y} \cdot 13 u$ & 3.327 & 1.júI & 56.4 & 21.6 & $5 \div .5$ \\
\hline 10 & $15.9,3$ & 5.585 & $4 \cdot 244$ & $34 \cdot 9$ & 26.5 & 75.9 \\
\hline \multicolumn{7}{|c|}{500 scrutches } \\
\hline
\end{tabular}


Table 60

\begin{tabular}{|c|c|c|c|c|c|c|}
\hline \multicolumn{4}{|c|}{ Averabe ifear volume $\mathrm{mm}^{3}$} & \multicolumn{3}{|c|}{ ২eIarive Perctniaje Hear } \\
\hline \multirow{2}{*}{ Load Ǩg } & A & $\equiv$ & C. & $\equiv \tau 0 \mathrm{~A}$ & $\approx$ to $\mathrm{A}$ & $i \approx J 3$ \\
\hline & Cast Iron & I I $\operatorname{ay} \in \mathbf{r}$ & z Lajer & $\begin{array}{l}\bar{D} \div \mathrm{A} \\
\mathrm{x} \dot{100} \mathrm{c}\end{array}$ & $\begin{array}{l}\approx \dot{A} \\
x \dot{i} \partial C^{c}\end{array}$ & $\begin{array}{l}c \div 3 \\
x \dot{100} \%\end{array}$ \\
\hline 2.5 & 1.915 & 0.238 & 0.163 & 15 & 0.5 & 56.5 \\
\hline 5 & 3.210 & 0.653 & 0.339 & 20.3 & 10.5 & 51.9 \\
\hline 10 & 5.452 & 1.096 & $0.7 i 3$ & 20.1 & 13 & 65 \\
\hline \multicolumn{7}{|c|}{10 Scratches } \\
\hline $\bar{c} .5$ & 3.050 & 0.559 & 0.412 & $13 \cdot 3$ & 13.5 & $7 \ddot{3.7}$ \\
\hline j & 5.211 & 0.848 & 0.729 & 16.2 & 13.9 & 85.9 \\
\hline 10 & 7.926 & 1.431 & 1.326 & 18 & 16.7 & 92.6 \\
\hline \multicolumn{7}{|c|}{50 Scratches } \\
\hline 2.5 & $4 \cdot 360$ & $0 . y 50$ & 0.926 & 21.7 & 21.2 & 97.4 \\
\hline 5 & 6.301 & $1.7 \sum 1$ & 1.374 & 27.3 & ¿1. 8 & 79.8 \\
\hline 10 & 9.450 & $\ddot{z} .9 \check{c} 5$ & 2.287 & 30.9 & 24.2 & 73.1 \\
\hline \multicolumn{7}{|c|}{$100 \mathrm{Sc}=\bar{a} i c h \in \mathrm{s}$} \\
\hline 2.5 & 6.132 & 2.481 & 1.070 & $40 \cdot 4$ & $\ddot{2} 2 \cdot 3$ & 55.2 \\
\hline 5 & $y \cdot I 30$ & 4.751 & $i \cdot シ j 0$ & 54.2 & 23.3 & $5 \dot{c} \cdot 3$ \\
\hline 10 & 15.943 & 6.855 & 3.750 & $4 \ddot{2} .8$ & 23.4 & 54.7 \\
\hline \multicolumn{7}{|c|}{200 scritches } \\
\hline
\end{tabular}


From these tables the extent of the improvement in wear resistance grovided by a hard coating can clearly be seen, whether with 1 or 2 lajers. "iith only one exception the 2 layer coatings orovide the better wear resistance al though, in relative terms, the difference between the 1 and 2 layers. is small in comparison with the difference between either the 1 or 2 layer resilts and the cast iron substrate.

These results apparently confirm expectations. The 1 layer deposics were thinner than the $z$ layer deposits for each of tine four processes. .ith the exception of the Thermal Spraying process, some dilution of the coating by the substrate could be expected and this would be manifested most clearly in the 1 layer coating resulting in pourer wear resistance. In the case of the oxy-acetylene process the porous nature of the deposit could be expected to impair wear resistance and this could have a more significant effect on the 1 layer deposit results. However, these results require a more rigorous examination before firm conclusions can be stated.

These comments relate to the processes in isolation and there is a need to compare them in a way which will permit ranking and enable a recommendation of the best process to be made. To aid this comparison the data in Tables 57 to 60 inclusive has been retabulated so that for each combination of test cunditions the processes can be rarised in order of best to worst perfornance. For ease oi comparison the data is separateci into two tables. In Table 61 tine results for the 1 and 2 layer dejosits are compared with the cast iron substrate whereas in Table 62 the 2 layer results are compared directly with the 1 layer results. 


\begin{tabular}{|c|c|c|c|c|c|c|}
\hline \multirow{2}{*}{$\begin{array}{c}\text { Number } \\
\text { of } \\
\text { Scratches }\end{array}$} & \multicolumn{2}{|c|}{$2.5 \mathrm{~kg}$} & \multicolumn{2}{|c|}{$5 \mathrm{KE}$} & \multicolumn{2}{|c|}{$10 \mathrm{KE}$} \\
\hline & 1 Layer & 2 Layers & 1 Layer & 2 Layers & 1 Layer & 2 Layers \\
\hline 10 & $\begin{array}{l}\text { TS }>\text { PS }> \\
O A>T I G\end{array}$ & $\begin{array}{l}\mathrm{TS}>\mathrm{PS}> \\
\mathrm{TIG}>\mathrm{OA}\end{array}$ & $\begin{array}{l}\mathrm{TS}>\mathrm{PS}> \\
\mathrm{OA}>\mathrm{TIG}\end{array}$ & $\begin{array}{l}\mathrm{TS}>\mathrm{PS}> \\
\mathrm{OA}>\mathrm{TIG}\end{array}$ & $\begin{array}{l}\mathrm{TS}>\mathrm{PS}> \\
\mathrm{OA}>\mathrm{TIG}\end{array}$ & $\begin{array}{l}\mathrm{TS}>\mathrm{PS}> \\
\mathrm{OA}>\mathrm{TIG}\end{array}$ \\
\hline 50 & $\begin{array}{l}\mathrm{PS}>\mathrm{OA}> \\
\mathrm{TS}>\mathrm{TIG}\end{array}$ & $\begin{array}{l}O A>P A> \\
T S>T I G\end{array}$ & $\begin{array}{l}\mathrm{PS}>\mathrm{TS}> \\
O A>\mathrm{TIG}\end{array}$ & $\begin{array}{l}P S>T S> \\
O A>T I G\end{array}$ & $\begin{array}{l}\mathrm{TS}>\mathrm{PS}> \\
\mathrm{OA}>\mathrm{TIG}\end{array}$ & $\begin{array}{l}\mathrm{TS}>\mathrm{PS}> \\
\mathrm{OA}>\mathrm{TIG}\end{array}$ \\
\hline 100 & $\begin{array}{l}\mathrm{PS}>\mathrm{TS}> \\
\mathrm{OA}>\mathrm{TIG}\end{array}$ & $\begin{array}{l}\text { PS }>\text { TS }> \\
O A>T I G\end{array}$ & $\begin{array}{l}\text { FS }>\text { TS }> \\
O A>T I G\end{array}$ & $\begin{array}{l}\mathrm{PS}>\mathrm{TS}> \\
\mathrm{OA}>\mathrm{TIG}\end{array}$ & $\begin{array}{l}\mathrm{PS}>\mathrm{TS}> \\
\mathrm{OA}>\mathrm{TIG}\end{array}$ & $\begin{array}{l}\mathrm{PS}>\mathrm{TS}> \\
\mathrm{OA}>\mathrm{TIG}\end{array}$ \\
\hline 500 & $\begin{array}{l}\text { ES > OA > } \\
T S>\mathrm{TIG}\end{array}$ & $\begin{array}{l}\mathrm{PS}>\mathrm{OA}> \\
\mathrm{TS}>\mathrm{TIG}\end{array}$ & $\begin{array}{l}\mathrm{PS}>\mathrm{TS}> \\
\mathrm{OA}>\mathrm{TIG}\end{array}$ & $\begin{array}{l}\mathrm{PS}>\mathrm{TS}> \\
\mathrm{OA}>\mathrm{TIG}\end{array}$ & $\begin{array}{l}\mathrm{PS}>\mathrm{TS}> \\
\mathrm{OA}>\mathrm{TIG}\end{array}$ & $\begin{array}{l}\mathrm{PS}>\mathrm{TS}> \\
\mathrm{TIG}>\mathrm{OA}\end{array}$ \\
\hline
\end{tabular}

\section{Layer and 2 Layer Deoosits Relative To The Cast Iron Substrate}

Table 62

\begin{tabular}{|c|c|c|c|}
\hline $\begin{array}{l}\text { Number of } \\
\text { Scratches }\end{array}$ & $2.5 \mathrm{Kg}$ & $5 \mathrm{~kg}$ & $10 \mathrm{Kg}$ \\
\hline 10 & $\mathrm{PS}>\mathrm{TS}>\mathrm{TIG}>\mathrm{OA}$ & $\mathrm{OA}>\mathrm{PS}>\mathrm{TIG}>\mathrm{TS}$ & $\mathrm{TS}>\mathrm{PS}>\mathrm{OA}>\mathrm{TIG}$ \\
\hline 50 & $\mathrm{OA}>\mathrm{TIG}>\mathrm{TS}>\mathrm{PS}$ & $\mathrm{OA}>\mathrm{TIG}>\mathrm{TS}>\mathrm{PS}$ & $\mathrm{TS}>\mathrm{PS}>\mathrm{TIG}>\mathrm{OA}$ \\
\hline 100 & $\mathrm{PS}>\mathrm{TIG}>\mathrm{TS}>\mathrm{OA}$ & $\mathrm{TS}>\mathrm{TIG}>\mathrm{OA}>\mathrm{PS}$ & $\mathrm{TIG}>\mathrm{TS}>\mathrm{PS}>\mathrm{OA}$ \\
\hline 500 & $\mathrm{PS}>\mathrm{TIG}>\mathrm{OA}>\mathrm{TS}$ & $\mathrm{PS}>\mathrm{TIG}>\mathrm{OA}>\mathrm{TS}$ & $\mathrm{PS}>\mathrm{TIG}>\mathrm{OA}>\mathrm{TS}$ \\
\hline
\end{tabular}

2 Layers Relative To 1 Layer Deposits

\begin{tabular}{|c|l|c|c|}
\hline Key & Process & Table 61 & Table 62 \\
\hline PS $=$ & Powder Spray $:$ el ding & 15 & 5 \\
\hline TS $=$ & Thermal Spraying & 8 & 3 \\
\hline OA $=$ & Oxy-acetylene Jielding & 1 & 3 \\
\hline TIG $=$ & Tungsten Inert Gas UEl ding & 0 & 1 \\
\hline
\end{tabular}

Learue Table to Show Top Processes 
Examination of Table 61 shows that there is no overall consistency within the ranking although there are a number of interesting features. For example in the cast of the 100 scratch test the order oi ranking (PS>SS>OAPIG) occurs in each of the six combinations. In the 500 scratch tests powder spray welding (PS) is the best in all the combinations and in the 50 scratch tests Eowier Spray :.elding (PS) is best in three of the six cominations. In the case of the 10 scratci tests rhernal Spraying (TS) proves the best in all combinations with the ranking order ( $T S>P S>O A>T I G$ ) occlirring in five out of the six cominations. Pernaps the most striking and consistent feature is that Tungsten Inert Gas Welding (TIG) is bottom in twenty two of the twenty four rankines. A simple league table snows that Fovder Spray ielding was tog of the rankings in fifteen cases, Thermal sprayin̈ in eight cases, Oxy-acetylene :̈elding in one case and Tungsten Inert Gas Welding not at all.

Examination of Table 62 reveals even less consistency, although for the 500 scratch test the ranking order (PS>TIG) OA>TS) is the same for each of the three loads. Once abain the simple league table showed Powder Spray Melding to be top of the rarkings on the most occasions, five cases in comparison with three each for phermal spraying and oxy-acetylene ":eIding, and one for Tunjsten Inert Gas \#elding̈.

From this consideration of tine wear test resuits it wolla be possible to conclude that, on balance: the Povder joray $\because$ Elding process is the best and Tungsten Inert Gas ".elding the worst; and two layers provide better wear resistance than one layer. However, these intuitive conclusions require testing against a more rigorous appraisal. For tinis purpose a statistical analysis of the results was performed. 


\section{1 .3 Statistical Analysis of viear Test Results (76)}

The test chosen for the analysis yas based on the stancard error of the mean and the procedure is described in Appendix 5. The tests were applied to each of the ranking groups and to ensure that each of the four processes was compared one with another, six tests were required. Hith a total of twenty four rankinf groups in Table 61 and t:elve in Table 62 a total of 192 comparisons were necessary. The results of these comparisons are summarised in Tables 63 to 65 .

\section{Table 63}

\begin{tabular}{|c|c|c|c|}
\hline $\begin{array}{l}\text { Number of } \\
\text { Layers }\end{array}$ & $\begin{array}{l}\text { Loall } \\
\text { Kg's }\end{array}$ & $\begin{array}{l}\text { Number of } \\
\text { Scratches. }\end{array}$ & $\begin{array}{c}\text { Statistically Significant } \\
\text { Differences }\end{array}$ \\
\hline 1 & 2.5 & 10 & \\
\hline 1 & 5 & 10 & Powder Spray welding Vs TIG \\
\hline 1 & 10 & 10 & Thernal Spraying Vs TIG \\
\hline 1 & 2.5 & 50 & \\
\hline 1 & 5 & 50 & \\
\hline 1 & 10 & 50 & \\
\hline 1 & 2.5 & 100 & . \\
\hline 1 & 5 & 100 & \\
\hline 1 & 10 & 100 & \\
\hline 1 & 2.5 & 500 & \\
\hline 1 & 5 & 500 & \\
\hline 1 & 10 & 500 & $\begin{array}{l}\text { Powder Spray telding Vs TIG } \\
\text { Thermal Spraying }\end{array}$ \\
\hline
\end{tabular}

One layer comparisons:

Inspection of Table 63 shows that statistically significant differences occurred in only 4 of the possible 72 comparisons. 
Table 64

\begin{tabular}{|c|c|c|c|}
\hline $\begin{array}{l}\text { Number of } \\
\text { Layers }\end{array}$ & $\begin{array}{l}\text { Load } \\
\text { Kgs. }\end{array}$ & $\begin{array}{l}\text { Number of } \\
\text { Scratches }\end{array}$ & $\begin{array}{c}\text { Statistically Significant } \\
\text { Differences }\end{array}$ \\
\hline 2 & 2.5 & 10 & \\
\hline 2 & 5 & 10 & \\
\hline 2 & 10 & 10 & $\begin{array}{l}\text { Thermal Spraying Vs. } \\
\text { Oxy-acetylene Welding }\end{array}$ \\
\hline 2 & 2.5 & 50 & \\
\hline 2 & 5 & 50 & \\
\hline 2 & 10 & 50 & $\begin{array}{l}\text { Powder Spray Welding Vs. TIG } \\
\text { Thermal Spraving }\end{array}$ \\
\hline 2 & 2.5 & 100 & $\begin{array}{l}\text { Powder Spray :Uelding Vs TIG } \\
\text { Thermal Spraying }\end{array}$ \\
\hline 2 & 5 & 100 & \\
\hline 2 & 10 & 100 & $\begin{array}{l}\text { Powder Spray Welding Vs TIG } \\
\text { Thermal Spraying }\end{array}$ \\
\hline 2 & 2.5 & 500 & \\
\hline 2 & 5 & 500 & Powder spray welding Vs TIG \\
\hline 2 & 10 & 500 & Powder Spray "ielding Vs TIG \\
\hline
\end{tabular}

Two layer comparisons:

Inspection of rable 64 snows that statistically significant difierences occurred in 9 out of the possibie 72 comparisons. 
Table 65

\begin{tabular}{|c|c|c|c|}
\hline $\begin{array}{l}\text { INumber of } \\
\text { Layers }\end{array}$ & $\begin{array}{l}\text { Load } \\
\text { Kgs }\end{array}$ & $\begin{array}{l}\text { Iumber of } \\
\text { Scratches }\end{array}$ & $\begin{array}{c}\text { Statistically Significant } \\
\text { Differences }\end{array}$ \\
\hline 1 Vs 2 & 2.5 & 10 & \\
\hline $1 \mathrm{Vs} 2$ & 5 & 10 & TIG \\
\hline 1 vs 2 & 10 & 10 & \\
\hline I Vs 2 & 2.5 & 50 & \\
\hline $1 \mathrm{Vs} 2$ & 5 & 50 & \\
\hline 1 Vs 2 & 10 & 50 & \\
\hline 1 Vs 2 & 2.5 & 100 & \\
\hline 1 Vs 2 & 5 & 100 & \\
\hline 1 Vs 2 & 10 & 100 & \\
\hline $1 \mathrm{Vs} 2$ & 2.5 & 500 & Powder Spray iielding \\
\hline $1 \mathrm{Vs} 2$ & 5 & 500 & \\
\hline 1 Vs 2 & 10 & 500 & \\
\hline
\end{tabular}

One layer Vs Two layer comparisons:

Inspection of Table 65 shows that statistically significant differences occurred in 2 out of the possible 48 comparisons.

The statistical analysis enables the results to be considered more objectively. It is clear from the results of the wear tests that the application of a hardfaced coating by any of the four processes significantly improves the wear resistance when compared with the results for the cast iron substrate. However, it is not possible to state categorically. that, with one layer deposited, any one process provides detter results than another. There is some indication that the TIG process may be the least satisfactory as it is shown to be significantly poorer in 4 comparisons. 
Intuitiveiy one night expect that the deposition of two layers ö hardiacing mignt provide a better basis for comparison. Ary influence of weak bonding or dilution should be diminisned by the deposition or̈ the additionai layer of hardiacing alloy. The fact that statistically significant differences occurred in y Ö̈ the comparisons could be considered to dear this expectation out.

However these results do not provide a clear clit lbest process' altnough TIG is once more seen as slonificantiy a pourer jrucess.

Although the wear test results show, with one exception, that the. two layer deposits provide betier wear resistance than the or.e layer deposits the improvement is not shown to be significantly better except in 2 or the 48 comparisons. As indicated earlier, the relative difference in wear resistance between the one and two layer deposits is small in comparison with either the one or t:ro layer resulis and the cast iron substrate.

The implicatzons of this analysis are clearly important to the selection of a hardacing process. This aspect wiIl be considerec more fully in the Discussion summary section.

\subsection{Surface Hardness Testing}

From tre results presented in Tables 41 - 44 it can be seen that the average hardness of the nurdfaced coatings is cunsiderably hiöner than the average hardiness of the grey cast iron sliostrate which is $223 \mathrm{HV}$. It can also be seen that the I layer deposits show a lower hardness than the 2 lajer deposits.

To aid the comparison of the 1 lajer and 2 layer deposits the data in raoles 41 - 44 inclisive has been summarised in the simple leagle tables shown below: 


\section{Layer Devosits}

\begin{tabular}{|c|c|}
\hline Poncer Suray neIding & $634 \mathrm{HV}$ \\
\hline Thermal Sparying & $604 \mathrm{HV}$ \\
\hline TIG & $508 \mathrm{HV}$ \\
\hline oxy-acetylene melding & $4 \dot{4} \dot{\mathrm{BVV}}$ \\
\hline E Layer Deposits & \\
\hline Powder Spray :..elding & $783 \mathrm{IV}$ \\
\hline Thermal Spraying & $720 \mathrm{FV}$ \\
\hline oxy-acetylene $\because$ elding & $50 \mathbf{O}_{4} \mathrm{HV}$ \\
\hline TIG & $567 \mathrm{HV}$ \\
\hline
\end{tabular}

Inspection of these tables shows that for each process a higher hardness is obtained with a 2 layer deposit. Furthermore, the Powder Spray "Velding process displays the highest hardness for both the 1 and 2 layer deposits followed by the Thermal Spraying process. The hardness values for the Oxyacetylene and TIG $\because e l d i n g$ processes are similar but each is appreciably lower than those for the two spraying processes. These results appear to be quite conclusive. However, they can be tested more rigorously by a statistical analysis. 5.ட்.l Staristical Analysis of Surface Hardness Results

The test chosen for the analysis follows the same procedure as in 5.1.3. The tests were applied to ensure that each of the fulir processes was compared one with anuther.

The results of these comparisons are sumarised in Table 66. 
Table 66

\begin{tabular}{|c|c|}
\hline $\begin{array}{l}\text { Whinger of } \\
\text { Layers }\end{array}$ & $\begin{array}{c}\text { Staitsicaliy Significant } \\
\text { Difierences }\end{array}$ \\
\hline 1 & $\begin{array}{c}\text { Powder Soray Helding } \\
\text { Vs } \\
\text { oxy-acetylene } \forall e l d i n g\end{array}$ \\
\hline 2 & $\begin{array}{c}\text { Powder Spray } \text { VI }{ }_{\text {Ving }} \\
\text { TIG }\end{array}$ \\
\hline $2 \mathrm{Vs} I$ & Powder Spray ielding \\
\hline
\end{tabular}

One layer and two layer comparisons:

Inspection of paole 66 shows that statisticaliy significant differences occurred only once in each of the two groups of six comparisons.

Two layer Vs one layer comparisons:

Inspection of Table 66 shows that a statistically significant difference occurred in only one of the four comparisons.

It is clear from the results of the surface hardness tests in Tables 41 - 44 that the apjication of a hardfaced coating by any of the four orocesses significantly increases the surface hardness when compared to the results for the cast iron substrate.

However, it is not possible from the statistical analysis to state catergorically that, with one layer deposited, any one process provides better results than anuther. Theie is some indication that the Fowder spray ":elding process may be the most satisfactory as $t$ t is snown to ve signdficantly better in one of the comparisons.

It inlgit be expected that the deposition of a second layer 
of hardiacinö alloy would provide a better basis for comparison. Any influence of dilution by the slibstrate should be diminished by the deposition of tine second layer.

Altholign the surface hardness test results snow, that the 2 layer deposits provide a better surface harciness than the 1 layer deposits, this was only shown to be statistically significant with the Powder Spray

\subsection{Macro Hardiness Profile Tests}

The average macro-nardness results presented in Tables 45 52 vere used to produce graphs wich are snown in Fizures 4.26 to 4.29 .

From the iigures it can be seen that, as could be expected, a general form of hardness profile was obtaired. A high macrohardness was obtained at the surface zone and this decreased with increasing distance from the surface until the hardness level of the suostrate was reached.

In all the processes the starting hardness was generally higher for the 2 layer deposits than for the 1 layer deposits. It can also be seen that the rate of decline is more pronounced for the Thermal Sprayin̈̈ and Powder Siray "ielding processes than the other two velding processes. The reason for this is that the weldin̈ processes pruvide a thicker coating and, although the nardness values are nut as high as the spraying̈ processes, due to diIution, this harkess is naintained for a greater depth.

\section{4 ijectron probe Microanalysis (EPMA)}

The approximate percentages of $\mathrm{Ni}, \mathrm{Cr}$, Si and Fe presented in rables $53-56$ were used to provide an indication uf the presence anci degree of dilution of the hardiacing alloy by the cast iron substrate.

From the results it can de seen that dilution occurs in 
all the deposits but is most evident in the melded deposits.

In the 1 lajer and 2 layer deposits the percentäe or iri present in the interiace area was $0.009 \%$ for both the thermal Sprayed and Fowder spray :elded deposits ard 4 with the TIG welded deposits. The percentage of iil tinen increased rapidly into the alloy until a constant level was reached. For the 1 layer devosits this was: Tinermal sprayed 50\%; powder spray 7 elded 53\%; 0xyacetjiene veiding $45 \%$; and TIG welding $44 \%$. For the 2 layer de osits the percentage of iri was: Thermal Sprayino $78 \%$;

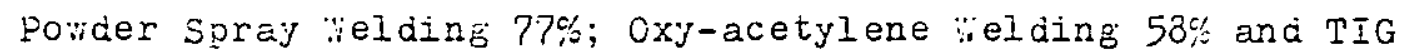
weiding 53\%. The $z$ layer devosits showed a higher percentage of $\mathrm{yi}$ in the alloy than did the 1 layer deposits. This was true for all the processes but the sprayed deposits showed a nigher ifi percentage in the alloy than the welded deposits. There was no evidence oi the presence of $\mathrm{Cr}$ in the bond layer oi either the 1 layer or 2 layer deposits produced by The:mal spraying or powder spray derected in the bond area $o_{i}$ the $0 x y$-acetylene deposit and $2 \%$ Cr in the PIG welded deposit. The Cr content then increased gradually from the interface to the body of the deposit finally reaching a constant value which was, for the 1 layer deposits: Powder spray welding $14 \%$, Thermal spraying $13 \%$, Oxy-acetylene

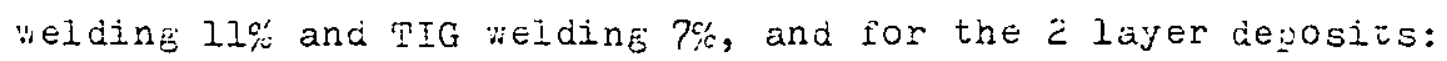
Powder spray weldinä 20\%, rihermal spraying 17\%, Oxy-acerylene welding $13 \%$ and IIG welding 11\%. The $\ddot{z}$ layer deposits showed a hisher percentage or $C r$ in the alloy than the 1 layer deposits for all the processes and the sprayed deposits showed a higher percentage of Cr in the alloy than the welded deposits.

The percenta $\overrightarrow{5}$ or $\mathrm{si}$ present in the interface area for 
both the 1 layer and 2 layer deposits was: Oxy-acetjlene weIding 0.00 c; Powder spray weldine 0.009 ; and for both Thermal spraying and TIG welding Io. ine amount of Si present

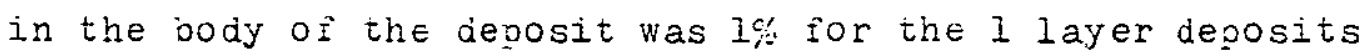
produced by each $0 \hat{i}$ the four methods and $2 \%$ for the 2 layer deposits.

The percentage $0: \mathrm{Fe}$ jresent in the interiace area was different for the 1 layer and 2 layer deposits. In the 1 layer deposits the percentage of Fe present was: Thermal spraying 4\%; Powder spray weldin: 5\%; Oxy-acetylene velding $10 \%$ and TIG Welding 17\%. In the 2 layer devosits the percentage of Fe present was: Therinal spraying and powder spray welding $4 \%$; Oxy-acetylene welding $6 \%$ and TIG welaing $10 \%$. There was a gradual decrease in Fe with distance from the interiace until a constant percentage was reached in the body of the deposit. For the 1 layer deposits this was: Thermal sorayine and Powder spray welding 4\%; Oxy-acetylene welding 8\% and TIG welding II\%. In the 2 layer deposits the percentage of Fe was: Thermal spraying and Powder spray welding 3\%; Oxyacetylene weldirg $5 \%$ and TIG welding $8 \%$. The 2 layer deposits showed a lower percentage of $F e$ in the alloy than did tine 1 layer deposits and the sprayed deposits showed a lower percentäe of Fe than did the weided deposits.

Frorr these resulis it can be seen that the sprayed deposits show less dillition of the hardiacing alloy by the substrate than the weided depcsits. Furtiermore, the amount of dillition is less for tne 2 layer deposits in both the sprayed and welded deposits.

\section{$5 . j$ Ostical licroscopy}

The photoinicrographs for the coatinus produced by Thermal 
sorajing and Powder soray weiding anc snown in Plates 4.1, 4.2, 4.5 and 4.6 display a fine structure consisting oi boride and carbide janticles uniformly distributed throlighout the matrix of the alloy. The boride and carbide particles are responsible for most of the hardness and abrasion resistance of the hardfaced coatines. The fine strlicture can be attributed to the minimum heat input associated with the processes which results in a fast cooling rate in the coating.

An exceilent metailurgicai bond appears to exist between the hardiaced coatings and grey cast iron substrate and none of the praphite, in the grey cast iron matrix, appears to have been burned out. The degree of dilution is seen to be low as is indicated by the narrow band representing the interface between the coating and matrix of the cast iron.

In the Thermal sprayed dejosit some spherical non-metaliic inclusions are visible, these appear to be isolated slag particles which colild have formed tinrough the action of the boron and silicon fluxing agents producing oxides and/or borates during the Thermal spraying process. The reason for their presence could be due to tine relatively low temperature of the phermal spraying process being insuficient to disperse away all these materials.

The photomicrographs for the coatings produced by oxyacetylene welaing and 'IG Welcing and shown in Plates 4.9 , 4.10, 4.13 and 4.14 display a coarse structure winich is made up of boride and carbide particles which have been distributed unevenly througholit the matrix of the alloy. The boride and caroide particles are responsible for most of the hardness and aorasion resistance of the hardfaced coating.

The coarse structure can be attriblited to the high heat 
input associated with these processes which produces a slow cooling rate in the coating.

Ar excellent metailurgical bond appears to have been achieved between the hardfaced cuating and the grey cast iron substrate. Despite tine higner heat input of these processes very litile graphite, if any appears to nave been burned out of tine cast iron. T.ee degree of dilution in the oxy-acetylene :elding deposit appears to be lower than that in the TiG process. The nigher dilution of the TIG process is indicated by a broader and more uneven band representinö the interface bet:ieen the coating and matrix of the cast iron, Plate 4.16. This uneveness or irregular band could also be caused by grit blasting prior to hardfacing. (45)

Some voids are visible in the $0 x y$-acetylene welding deposits and oecause oI their shape and size would appear to be gas holes, possibly caused by entrapped gases durinö the deposition process.

\subsection{Operator Factor}

The different procedires required for each of the processes were described in section 3.5. These procedures require various degrees of operator input and skill and tris may influence tine quality uf the coatings dejosited and, consequentiy, tine results o $i$ this investigation. In this section soine attempt, Winist inevitably subjective, is made to quantify and comment on these fuctors.

\subsubsection{Nhermal Spraying}

The iherual Spraying process required a good knowledge of welding to set up the equipment but only minimal operator srills to deposit the alloy. The speed of alloy deposition was very fast and large areas colld be covered quickly. 
The surface înisi was extremely smooth, clean, free ô jorosity and specimen preparation requirec a minimum of surface grinding. The thickness $0 \hat{i}$ the deyosited coatings ranged from $1.0 \mathrm{~mm}$, for the 1 layer deposit, to $1.5 \mathrm{~mm}$ for the 2 layer deposit.

\section{6 .2 Powder Soray Uelding}

This process required a good knowledge of welding to set liv the equipment but only minimal operator sisills to deposit the alloy. The speei of alloy depositiun was fast and large areas could be covered quicirly.

The surface finisi was smouth, clean, iree of porosity and specimen preparation required a minimum of surface grinding. The thickness of the deposited coatings ranged from $2.0 \mathrm{~mm}$, for the 1 layer deposit, to $2.3 \mathrm{~mm}$ for the 2 layer deposit.

\section{6 .3 oxy-acetylene lelding}

The Oxy-acetylene process required a good knowledge of welding to set up the equipment and a high level of operator skills to deposit the alloy. The speed of alloy deposition was slow although a large area could be covered.

The surface finisin was jorous, rough and dirty in appearance. The specinen was distorted by the nigh heat input and slow travel speed and required considerable surface grinding to achieve a smooth inish. The thickness of the deposited coatines ranged from. $3.0 \mathrm{~mm}$, for the 1 layer dejosit, to $4.0 \mathrm{~mm}$ for the 2 layer deposit.

\section{6 .4 Tungsten Inert Gas :ielding̈}

Like the Oxy-acetjlene process a bood knowledge of welding is required to set up the equipment and a high level of operator skills tu deposit the alloy. The speed of alloy deposItion was slow although a Iarge area colild be covered. 
The surace finish was reusunably smooth, clean anc free oi porosity. The specinen was sifgitly distorted oy the high heat input and siow travel speed, but preparation of the specimen required only minimal surface grundine. The thickness or the deposited coatings ranged from $3.0 \mathrm{~mm}$, for the 1 lajer deposit, to $4.0 \mathrm{~mm}$ for the 2 layer deposit.

\subsection{Discussion summary}

After dejosition oy all four processes of the hardfacing alloy, an excelient metallurgical bond existed bet:ieen the hardiaced coatings and the grey cast iron suostrate. ilone of the grapnite in the matrix of the grey cast iron appeared to have been burned olit, despite the high heat inout from the welding processes. The heat input fron the processes determined the siructure of the alloy by influencing tine cooling rate. The spraying processes produced a lesser heat input whici produced a fast cooling rate and gave a fine structure, whereas tine welding processes provided a high heat input which prociuced a siow cooling rate resultine in a coarse structure.

These structures consist of boride and caroide particles which are distributed throughout the matrix of the alloy and are responsible for most or the hardness and abrasion resistance. The rine structure of the sprayed coatings showed a uniform distribution of these particles in the matrix, whereas tine coarse structure of the welded coatings showed an uneven distriolition of the varticles in the matrix.

The surface hardness tests s:owed the hardness of the nardiaced coatings to be between 2.25 and 3.5 times higher than the grey cast iron suostrate. This hardness decreased with increasing distance from the surface until the hardness of the substrate wašreached. Dilution of the coating by the substrate 
Was expected to occur, especially in the one layer coatings deposited by the weicing processes. This was sno:*n to be the case by the EPHA results. Although it might be expected that the deposition of a second layer of coating would be beneficial in overcoming the problem of dilution, statistical signiricance testing showed this only to be so in the case oi Powder Siray "ielding.

Although surface hardness is said to be a poor guide to abrasion life (35), wich derives principally from the structure, hardness is a major factor and this explains why materials hardened on the surface are used wherever possible for wearing surfaces. It is clear from the results that the application of a hardfaced coating by any of the four processes significantly improves the wear resistance when compared with the results for the grey cast iron substrate.

Inspection of the wear test results suggests that the processes can be ranked in order of performance and that 2 layer deposits provide better wear resistance. However, statistical analysis did not identify an obvious best overall process, although there were good indications that the powder Spray : :elding process was a strong̈ candidate for tine best process and TIG welding was the worst.

From the practical and econouic viewpoints the sprajing processes produced a controlled, thinner coating with a smoother surface finish with minimal dizution by the substrate. These coatings required less surface grinding to produce a uniform finish and would tinerefore be particularly suitable for close tolerance enfineering applications. linimal operator welding skills are required by the spraying processes, when compared with the welding processes, and the training of personnel would 
not be difficult. The statistical analysis snomed that the deposition of 2 layers of coating did not significantly improve wear resistance ard this is an imoortant finding irom the economic viewpoint.

The Powder Spray Ueiding process is based on the use of Oxy-acetylene welding equipment and both processes are inexpensive, versatile and portable. In comparison the Thermal Spraying and TIG : :eldins processes.and equipment are more expensive and less versatile.

on the basis of the results of the investigation and the ease of use the powder spray Welding process could be most strongly recommended. However, the use of the other processes should not be excluded ai; tine choice of a process depends on the job specifications and consideration must be given to the following:

1. Cost

2. Component design (shape, size, thickness etc.)

3. Thicisness of coating required

4. Type of surface inish required 
CHAPTER 6

CONCLUSIONS 


\section{CHAPTER 6}

\section{CONCLUSIONSS}

1. The investigation proved that a i $i-C r-B$ hardiacing alloy coula be successiully deposited, by each of tine iour processes considered, onto grey cast iron substrate without burning out essential elements, such as graphite, from the cast iron.

2. The application oi a hardfacing alloy coating reduced abrasive wear to between $2 \%$ and $55 \%$ of that experienced by the cast iron substrate. The actual improvement depending upon the coating process, the rumber of layers and the wear test conditions (load and number of scratches). 3. The results of the wear test programme were consistent in showing that wear volume increased with both increased load and increased test duration. 4. Statistical analysis of the wear test results did not show a clear and consistent ranking of processes with respect to wear resistance. However, there was some evidence to show that the best results were achieved with the Powder spray velding process and the worst with the Tungsten Inert Gas Welding process. 5. Statistical analysis of the wear test results showed that there was in general no benefit to be gained by applying two layers of hardfacing alloy ratier than one layer.

6. The surface hardiness of the hardfaced coatings was between 2.25 and 3.5 times greater than that of the cast iron substrate, depending on the process and the number of layers deposited. 
7. Statistical analysis of the surface hardness tests did not show that any one of the processes was consistently the best. However, there was some evidence to show that the Powder Soray Uelding process produced the better results. The improvement in surface narciness obtained when two layers rather than one layer were apolied by the Powder Spray ielding process was snown to be statistically significant.

3. The macro hardness profile tests showed that the highest values were obtained in the surface zone and that hardness. decreased with increasing distance from the surface until the hardness level of tine substrate was reached. The rate of deciline in hardness was more pronounced in the Powder Spray Melding and Thermal Soraying processes than it was in the Oxyacetylene and TIG welding processes.

9. The EPMA results provided evidence that there was some dilution of the hardiacing coating by the substrate and that this was most pronounced in the oxy-acetylene and TIG welded deposits.

10. From the optical microscopy evidence each of the processes produced an excellent bond between the hardiacing coating and the substrate. There was no evidence of graphite having being burned out of the substrate.

11. A fine metallurgical structure was observed in the coatings deposited by the Powder Spray $\dddot{i}$ elding and Thermal Spraying: orocesses whereas a coarse structure was observed in the coatings deposited by the Oxy-acetylene and TIG welding processes. The difference can be attributed to the higher heat input and slower solidification rates associated with the latter two processes.

12. Each of the processes required a good knowledige of welding ... 
procedures to set up the equipment. Hovever, minimum operatur skills were required by either the Powder spray ielding or Thermal Spraying processes to produce a fast rate of deposition and a smooth, clean, pore-firee deposit. A higher level of operator skill was required for the Oxy-acetylene and TIG welding processes and the oxy-acetylene process produced tine ieast satisfactory deposit with associated distortion. 
CHAPTER 7

SUGGESTIONS FOR FURTHER WORK 


\section{SUGGESTIUIS FOR FUPTEEP WORK}

Sugbestions for further work can be made from the investigation, these are:

1. The requirement for nechanical strength of hardfaced coatings vary widely according to the particular service conditions oi the component. Further woris could be carried out in testing the pensile strengti of the bond and internal strength of the deposit. These tests would ada a valuable extension of knowledge to the work already discussed in the investigation.

The tests would consist of dejositing the hardiaced coatings onto one face oi a purposely designed specimen. This coating would then be joined by a recommended adhesive (75) to the face of a second purposely designed specimen and then measuring the force required to pull the two specimens apart. A device for holding the specimens would have to be designed and marufactured to fit a stancard Tensile testing machine. 2. In the investigation only one grade of cast iron was used as tine substrate. Flirtiser work could be carried out using other grades and tjpes of cast irons especially the alloyed and unalloyed wite cast irons, winch have a problem with cracing during repair by welding.

The main calises of cracsing are due to:

1. Expansion and contraction caused by localized heat input which exceeds a threshold limit.

2. The contracting weld bead creating high tensile strains on the Heat Afifected Zone, during cooling.

Furtiner work carried out by using the same or similar 
processes to those in tne investifation, especially the spraying processes wich are relativeiy cold processes and a low inelting temperature hardiacing alloy could help to overcome problems when repairing or reclaiming cast irons to resist abrasive wear. 



\section{References}

1. BS 1452 : 1977, British Standards Institute

2. Analytical Feport, Foseco International Itd.

3. Deloro Stelizie Lia., Sooklet iło. E39, 1968, Deceroer, p 8

4. Metco Eulietin 125, E8500/6/60, 1957 January

5. Mail Colmonoy Lta. Eeport, Surface Engineering, 1935, V1, 3, pp $167-168$

6. Mali Colmonoy Lid. keport, Verals and Haterials, 1985, July VI, 7, p 443

7. D. Elits and R. L. Squires, Getal Construction, 1983, July, 15, '7, p? 388-393

8. K. J. Allnat and G. R. Bell, International Collociuorum on Hardfacing Haterials in Nuclear power Plants, Avignon, France, 1980, September 25th-26th pp 57-64

9. A. Watting, British Welding Journal, 1966, September, V13, 9, pp 526-532

10. M. Riddiough, Hetal Construction and Eritish ":elding Journal, 1969, March, v1, 3, pp 126-129

11. A. C. Davies, The Science and Fractice of Helding, Carbridse university Press, 1984, v2, pp 56-62

12. E. Wallace, :..elding and i.etal Fabrication, 1959, January, v27, 1, pp 5-13

13. R. L. Baker, welding Journal, 1982, July, v6l, pp 42-44

14. K. H. Koupman and R. S. Zucnowsisi, Welding journal, 1956, July, v35, po 665-671

15. T. Ellis and G. G. Garrett, Surïace Engineering, 1986, $\mathrm{V} 2, \cdots, \mathrm{pp}$ 55-66

16. A "iding Institute seminar, Hetal Construction, 19?5, December, 17,12, p 616 


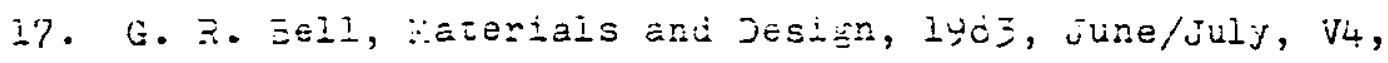
$\supseteq 2755-790$

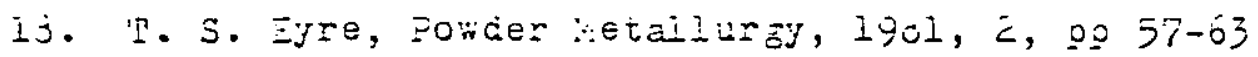

19. W. O. Aiexander, The Vetailurast and Vaterials Tecnnologist

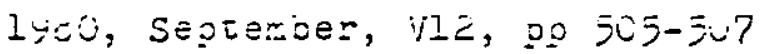

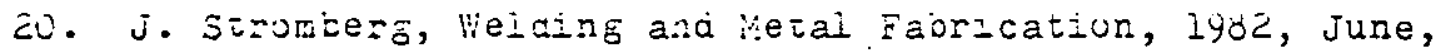

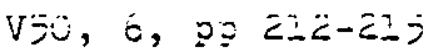

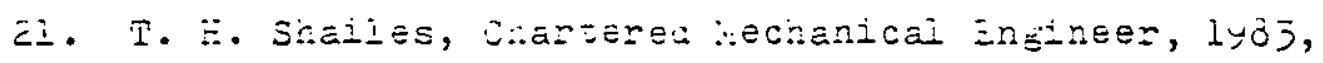
Segtender, vjo, บ, 20 \$0-50

2Z. E. Ii. Grejory, bieing and ietal Faorication, 1954,

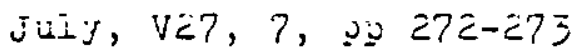

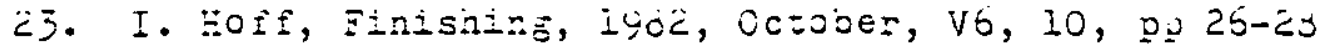

24. :. L. Murgan, Joining Of Iron Castings RCIRA, Conference at Lugnoorough iniversity oì Tecinology, 1970, April, $2003-433$

25. M. I. Paze, HetaI Construction and Eritish leiding Journal 1909 , Aüsisi, VI, 3, ag $39 \bar{c}-39 j$

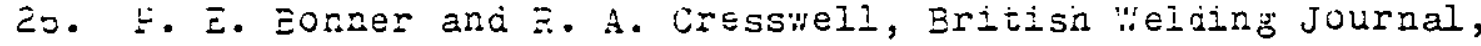

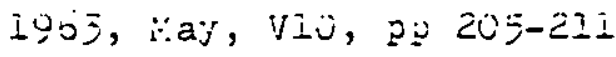

“7. Deloro steilite ita., 34j/E, Iy74, March, p 7

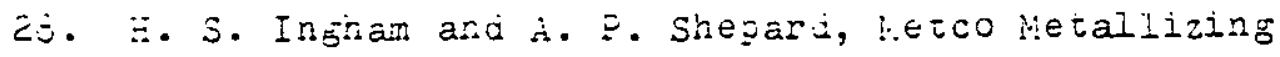
Fardiouch, IIl, Fo:izer process, p 535

E;. I. F. Spencer, Weiding̈ Engineer, ly70, November, po 39-48

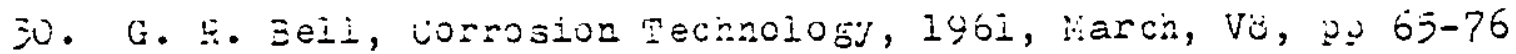

31. H. E. Ularse, Welding journal, I93I, July, V00, pp 27-29

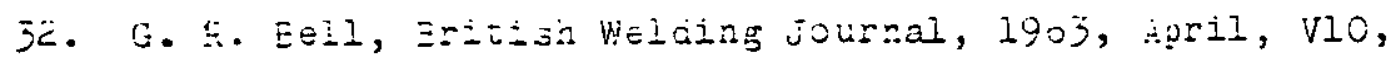
$4,20150-150$

j引. W. Fu Eurino-sriti, welding and Metal Faorication, 1959,

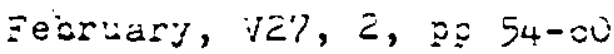

j4. C. R. Beil, chemicai Processing, ly64, september, vX, 9 ,

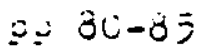


35. J. G. Barrington-stiles, British :̈elding Journal, 1963, April, V10, 4, pp 111-116

36. A. C. Davies, The science and Practice of ijelding, Camoridge University Press, 1984 , V1, p 13

37. Council oí Iron Founäy Association, Eooklet 14, Pall Mall, London

38. H. S. Ingham and A. P. Shepard, Hetco lietallizing Earibook, P $B 29$

59. R. L. Apps, Eritish Welding Jcurnal, I967, December, VI4, p $6 \ddot{z 7}$

40. J. G. Barrington-stiles, Eritisi ฟelaing Journal, 1962, June, v9, pp 367-370

41. W. E. Bellard, Eritish Velding Journal, 1962, June, V9, 6, po $363-364$

42. The Commonwealth Industrial Gases Ltd., Process Information, No. $1, \mathrm{pp} 1-16$

43. C. E. Jones and H. Griffiths, Eritish !!elding Journal, 1963, November, $\mathrm{V} 10,11, \mathrm{pp} 546-551$

44. H. S. Ingham and A. P. Shepard, Vetco Metallizing Handbook, p E3

45. W. Riddiougn, Eritisn :Selding Journal, 196̈̈, Nay, V9, pp $285-290$

46. E. N. Gregory, Metal Construction, lyodo, December, V12, yp 685-690

47. E. H. Simons, Metal Wear a Brief Outline, Fredricis Muler Ltd., 1972

48. C. Lipson, Wear Considerations in Design, Prentice Hall, $1967^{\circ}$

49. A. i. Clegg, H.Sc Thesis, Loughborough University of Technology, 1976 
50. T. S. Eyre, ietals Technology, 1984, Harch, Vll, po 81-90

51. J. K. Lancaster, Institute of Hetal Finishing, 1978, February, V56, po 145-153

52. C. Sharpe, Design Ëngineering, 1983, December, po 41-44

53. C. R. đejmuelier, Welding Design and Fabrication, 1983, Feoruary, p? 37-46

54. H. S. Ingham and A. P. Shepard, inetco Flame Spray Handbook, VI, p A.213

55. Health and Safety Executive, Eooklet 50, 1977

56. BS 638 : 1966 Eritish Standards Institute

57. Department of Employment and Productivity, Booklet 306,1970

58. Protection of Eyes Kegulations, 1974, H.M.S.0. NO. 1681

59. J. R. Franklin, welding Feview, 1983, Februar:, V2, I, pp 13-15

60. H. S. Inginam and A. P. Shepard, The Flame Spray tiandbook 1964, pp A3-A5

61. B. E. Paton, British :elding Journal, 1966, April, V13, 4, pp 201-206

62. Vetco Type 2 P Thermospray Gun, Instruction kanual, Cat. No. $P 777,1965$

63. The Commoneal th Industrial Gases Lid., Form iio. 127ن49a, 1984, March, pp $26-29$

64. F. Koenigsberger and k. Adair, Velding Technology, Nacmillan and Company Ltd., London, 1965

65. A. C. Davies, The Science and Practice of llelding, Cambridge University Press, 1984, V2, pp 261-262

66. A. C. Davies, The Science and Practice of Helding, Cambridge liniversity Press, 1984, V2, pp 154-155

67. M. S. Polyak, ̈elding Production, 1963, V10, pp 4l-42 
68. D. Rediy and 3. S. Nau, year Testing, The British Fydromecinanics Research Association, T.N. 940, 1960, Marcin, p 28

69. H. R. Shetty, T. H. Kosel and H. F. Fiore, Wear, 1982, 80, py $347-376$

70. P. R. Gibson, Ph.D Thesis, Lougnoorough University of Tecinnolo5y, 1984

71. Razavizadeh and 3. L. Davies, Wear, Lyól, 69, pp 355-367

72. Minoru OKada and Hirosin Maruo, Britisn : elding Journal, 1968, August, V15, 8, p 373

73. BS 1295 : 1959 , Britisn Standard Institute

74. T. S. Eyre and F. Wilson, Lubrication Ëngineering, 1973, February, V2, pp 65-72

75. Ketco Researci Laboratory Report 106, 1973, p 93

76. W. E. Duckworth, statistical Techniques in Technological Research: An Aid to Research Productivity, Methuen, Londion, 1968, p 27 
APPENDIX 1

n. 


\section{APPENDIX 1}

\section{WEAR VOLUME FOR RECIPROCATING DIANOND TEST}

Derivation: (Ref. FIG. 13)

The wear tract was assumed to be a similar form to the diamond, i.e. $120^{\circ}$ inc. angle

$$
0.2 \mathrm{~mm} \text { tip radius }
$$

$$
\begin{aligned}
\operatorname{Tan} 60 & =\frac{i}{2} \mathrm{w} / \mathrm{h}=\mathrm{w} / 2 \mathrm{~h} \\
2 \mathrm{~h} & =\frac{\mathrm{w}}{\operatorname{Tan} 60} \\
\text { Hence } \mathrm{h} & =\frac{\mathrm{w}}{2 \sqrt{3}} \\
\text { Area } \triangle \mathrm{ABC} & =\frac{1}{2} \mathrm{w} \times \frac{\mathrm{w}}{2 \sqrt{3}} \\
& =0.144 \mathrm{w}^{2} \mathrm{~mm}^{2}
\end{aligned}
$$

$$
\begin{aligned}
& \text { Area } \triangle E F C=0.069 \times D C \\
& \text { Tan } 60=\frac{0.069}{D C} \\
& \text { Hence DC }=\frac{0.069}{\sqrt{3}}=3.98 \times 10^{-2}
\end{aligned}
$$

$$
\text { Area } \begin{aligned}
\triangle \text { EFC } & =0.069 \times 3.98 \times 10^{-2} \\
& =2.75 \times 10^{-3} \min ^{2}
\end{aligned}
$$

$$
\begin{aligned}
\sin \frac{\theta}{2}=\frac{0.069}{0.2} \quad \frac{\theta}{2} & =20.18^{\circ} \\
\theta & =40.36^{\circ}
\end{aligned}
$$




$$
\begin{aligned}
\text { Area Segment GEHF } & =\frac{40.36}{360} \times \pi \times 0.2^{2} \\
& =1.41 \mathrm{~mm}^{2} \times 10^{-2} \\
x & =\sqrt{\left(0.2^{2}-0.069^{2}\right)} \\
& =0.188 \mathrm{~mm}^{2}
\end{aligned}
$$

$$
\begin{aligned}
\text { Area } \triangle \mathrm{GEF} & =0.069 \times 0.188 \\
& =1.297 \times 10^{-2} \mathrm{~mm}^{2} \\
\text { Area EDHF } & =1.41 \times 10^{-2}-1.297 \times 10^{-2} \\
& =1.12 \times 10^{-3} \mathrm{~mm}^{2}
\end{aligned}
$$

Volume of scratch

$$
\begin{aligned}
& =(\text { Area } \triangle \mathrm{ABC}-\text { Area } \triangle E F C+\text { Area } \\
& \text { EDHF } \times \text { s.troke length } \\
& =\left(0.144 \mathrm{w}^{2}-2.75 \times 10^{-3}+1.12\right. \\
& \left.\times 10^{-3}\right) \times \text { stroke length } \\
& =\left(0.144 \mathrm{w}^{2}-1.63 \times 10^{-3}\right) \times \mathrm{L}
\end{aligned}
$$





\section{Wear Volume Vs Load}

\begin{tabular}{|c|c|c|c|c|c|c|c|c|c|}
\hline & \multicolumn{3}{|c|}{$2.5 \mathrm{kgs}$} & \multicolumn{3}{|c|}{$5 \mathrm{Kgs}$} & \multicolumn{3}{|c|}{$10 \mathrm{Kgs}$} \\
\hline $\begin{array}{l}\text { Test } \\
\text { No } \\
\end{array}$ & $\begin{array}{c}\text { Scratch } \\
\text { Width } \\
\text { mm }\end{array}$ & $\begin{array}{l}\text { Wear } \\
\text { Volume } \\
\text { mm } 3\end{array}$ & $\begin{array}{l}\text { Wear } \\
\text { Votume } \\
\text { Average }\end{array}$ & $\begin{array}{l}\text { Scratch } \\
\text { width } \\
\text { mm }\end{array}$ & $\begin{array}{l}\text { Wear } \\
\text { Votume } \\
\text { m m 3 } \\
\end{array}$ & $\begin{array}{l}\text { Wear } \\
\text { Volume } \\
\text { Average }\end{array}$ & \begin{tabular}{|c|} 
Scratch \\
width \\
m m
\end{tabular} & $\begin{array}{l}\text { Wear } \\
\text { Volume } \\
\text { mm } 3\end{array}$ & $\begin{array}{l}\text { Wear } \\
\text { Volume } \\
\text { Average }\end{array}$ \\
\hline 1 & $\begin{array}{l}0.5080 \\
0.5080 \\
0.5588 \\
0.6096 \\
0.5096\end{array}$ & $\begin{array}{l}1.421 \\
1.421 \\
1.733 \\
2.075 \\
2.075\end{array}$ & 1.745 & $\begin{array}{l}0.8382 \\
0.6604 \\
0.6096 \\
0.6558 \\
0.7112\end{array}$ & $\begin{array}{l}3.981 \\
2.446 \\
2.075 \\
2.643 \\
2.848\end{array}$ & $\varepsilon .798$ & $\mid \begin{array}{l}0.7366 \\
0.8128 \\
0.9652 \\
0.9144 \\
0.8382\end{array}$ & $\begin{array}{l}3.060 \\
3.740 \\
5.300 \\
4.750 \\
3.981\end{array}$ & 4.166 \\
\hline 2 & $\begin{array}{l}0.6096 \\
0.5588 \\
0.5334 \\
0.5334 \\
0.5334\end{array}$ & $\begin{array}{l}2.075 \\
1.733 \\
1.573 \\
1.573 \\
1.573\end{array}$ & 1.70 .5 & $\begin{array}{l}0.6096 \\
0.7366 \\
0.7112 \\
0.8636 \\
0.8128\end{array}$ & $\begin{array}{l}2.075 \\
3.060 \\
2.848 \\
4.230 \\
3.740\end{array}$ & 3.130 & $\begin{array}{l}1.0922 \\
0.9652 \\
1.1430 \\
0.9144 \\
1.0160\end{array}$ & $\begin{array}{l}6.805 \\
5.300 \\
7.459 \\
4.750 \\
5.088\end{array}$ & 5.880 \\
\hline 3 & $\begin{array}{l}0.6858 \\
0.6604 \\
0.6350 \\
0.6096 \\
0.7366\end{array}$ & $\begin{array}{l}2.643 \\
2.446 \\
2.272 \\
2.075 \\
3.060\end{array}$ & 2.499 & $\begin{array}{l}0.7874 \\
0.7874 \\
0.8382 \\
0.8382 \\
0.7874\end{array}$ & $\begin{array}{l}3.505 \\
3.505 \\
3.981 \\
3.981 \\
3.505\end{array}$ & 3.695 & $\begin{array}{l}1.1176 \\
1.0160 \\
1.0414 \\
0.9906 \\
0.9398\end{array}$ & $\begin{array}{l}7.129 \\
5.880 \\
6.181 \\
5.587 \\
5.022\end{array}$ & 5.959 \\
\hline 4 & $\begin{array}{l}0.4826 \\
0.6096 \\
0.5588 \\
0.5334 \\
0.4826\end{array}$ & $\begin{array}{l}1.276 \\
2.075 \\
1.733 \\
1.573 \\
1.276\end{array}$ & 1.586 & $\begin{array}{l}0.7874 \\
0.76 z 0 \\
0.7366 \\
0.7366 \\
0.7112\end{array}$ & $\begin{array}{l}3.505 \\
3.279 \\
3.060 \\
3.060 \\
2.848\end{array}$ & 3.250 & $\begin{array}{l}0.9652 \\
0.9652 \\
0.9652 \\
0.9652 \\
0.9652\end{array}$ & $\begin{array}{l}5.300 \\
5.300 \\
5.300 \\
5.300 \\
5.300\end{array}$ & 5.300 \\
\hline 5 & $\begin{array}{l}0.5080 \\
0.6096 \\
0.5080 \\
0.7112 \\
0.6604\end{array}$ & $\begin{array}{l}1.421 \\
2.075 \\
1.421 \\
2.848 \\
2.446\end{array}$ & $=.042$ & $\begin{array}{l}0.6858 \\
0.7112 \\
0.8128 \\
0.8128 \\
0.7874\end{array}$ & $\begin{array}{l}2.643 \\
2.848 \\
3.740 \\
3.740 \\
3.505\end{array}$ & 3.295 & $\begin{array}{l}1.1176 \\
1.0160 \\
1.0414 \\
0.9906 \\
0.9398\end{array}$ & $\begin{array}{l}7.129 \\
5.880 \\
6.181 \\
5.587 \\
5.022\end{array}$ & 5.959 \\
\hline
\end{tabular}


Wear Volume Vs Load

\begin{tabular}{|c|c|c|c|c|c|c|c|c|c|}
\hline & \multicolumn{3}{|c|}{$2.5 \mathrm{Kgs}$} & \multicolumn{3}{|c|}{$5 \mathrm{Kgs}$} & \multicolumn{3}{|c|}{$10 \mathrm{Kgs}$} \\
\hline $\begin{array}{l}\text { Test } \\
\text { No }\end{array}$ & \begin{tabular}{|c|} 
Scrutch \\
Width \\
mm
\end{tabular} & $\begin{array}{c}\text { Wear } \\
\text { Volume } \\
\text { mm } 3\end{array}$ & $\begin{array}{l}\text { Wear } \\
\text { Volume } \\
\text { Average }\end{array}$ & \begin{tabular}{|c|}
$\begin{array}{c}\text { Scratch } \\
\text { Width } \\
\mathrm{mm}\end{array}$ \\
\end{tabular} & \begin{tabular}{|c|} 
Wear \\
Volume \\
mm 3 \\
\end{tabular} & $\begin{array}{l}\text { Wear } \\
\text { volume } \\
\text { Avercge }\end{array}$ & \begin{tabular}{|c|} 
Scratch \\
Width \\
mm
\end{tabular} & \begin{tabular}{|c|} 
Wear \\
Volume \\
mm 3
\end{tabular} & $\begin{array}{l}\text { Wear } \\
\text { Volume } \\
\text { Average }\end{array}$ \\
\hline 1 & $\left\{\begin{array}{l}0.4572 \\
0.6004 \\
0.5334 \\
0.6004 \\
0.6096\end{array}\right.$ & $\begin{array}{l}1.138 \\
2.446 \\
1.573 \\
2.446 \\
2.075\end{array}$ & 1.935 & $\begin{array}{l}0.6858 \\
0.9906 \\
0.8128 \\
0.8890 \\
0.8636\end{array}$ & $\begin{array}{l}2.643 \\
3.587 \\
3.740 \\
4.487 \\
4.230\end{array}$ & 4.137 & $\mid \begin{array}{l}1.1430 \\
1.3208 \\
1.2192 \\
1.0922 \\
1.0668\end{array}$ & $\begin{array}{l}7.459 \\
9.983 \\
0.496 \\
6.805 \\
6.490\end{array}$ & 7.846 \\
\hline 2 & $\begin{array}{l}0.6058 \\
0.7112 \\
0.8128 \\
0.8128 \\
0.7874\end{array}$ & $\begin{array}{l}2.643 \\
=.848 \\
3.740 \\
3.740 \\
3.505\end{array}$ & 3.295 & $\begin{array}{l}1.1176 \\
1.0160 \\
0.9398 \\
1.0414 \\
0.9906\end{array}$ & $\begin{array}{l}7.129 \\
5.880 \\
5.022 \\
6.181 \\
5.587\end{array}$ & 5.959 & $\begin{array}{l}1.2938 \\
1.0922 \\
1.2446 \\
1.2446 \\
1.3208\end{array}$ & $\left\{\begin{array}{l}0.143 \\
6.805 \\
8.857 \\
8.857 \\
9.983\end{array}\right.$ & 3.529 \\
\hline 3 & $\begin{array}{l}0.7874 \\
p .7874 \\
0.8582 \\
1.8382 \\
p .7874\end{array}$ & $\begin{array}{l}3.505 \\
3.505 \\
5.981 \\
3.981 \\
5.505\end{array}$ & 3.695 & $\begin{array}{l}0.9906 \\
1.1176 \\
1.1176 \\
1.0160 \\
1.0160\end{array}$ & $\begin{array}{l}5.587 \\
7.129 \\
7.129 \\
5.830 \\
5.880\end{array}$ & 6.321 & $\begin{array}{l}1.2446 \\
1.2446 \\
.2446 \\
.2446 \\
1.2446\end{array}$ & $\begin{array}{l}8.857 \\
8.857 \\
3.857 \\
8.357 \\
8.857\end{array}$ & 3.857 \\
\hline 4 & $\begin{array}{l}0.6350 \\
0.7112 \\
0.6358 \\
0.6358 \\
0.7874\end{array}$ & $\begin{array}{l}2.272 \\
2.848 \\
2.643 \\
2.643 \\
3.437\end{array}$ & 2.788 & $\begin{array}{l}0.8636 \\
0.9398 \\
0.8890 \\
0.9652 \\
0.9652\end{array}$ & $\begin{array}{l}4.230 \\
j .022 \\
4.48 ? \\
j .300 \\
5.300\end{array}$ & 4.487 & $\begin{array}{l}1.0414 \\
1.1176 \\
1.0668 \\
1.0668 \\
p .9652\end{array}$ & $\begin{array}{l}6.181 \\
7.129 \\
6.490 \\
0.490 \\
5.300\end{array}$ & 6.318 \\
\hline 5 & $\left\{\begin{array}{l}0.7366 \\
0.8128 \\
0.9144 \\
.8382 \\
0.6350\end{array}\right.$ & $\begin{array}{l}3.060 \\
3.740 \\
4.750 \\
3.901 \\
2.272\end{array}$ & 3.560 & $\begin{array}{l}0.838 \\
1.0160 \\
0.9398 \\
0.8890 \\
0.3890\end{array}$ & $\begin{array}{l}3.981 \\
5.380 \\
5.022 \\
4.487 \\
4.487\end{array}$ & 4.771 & $\begin{array}{l}1.1430 \\
1.1430 \\
.2192 \\
.2192 \\
1.2192\end{array}$ & $\begin{array}{l}7.459 \\
7.459 \\
8.496 \\
8.496 \\
8.496\end{array}$ & 3.081 \\
\hline
\end{tabular}


Wear Volume Vs Load

\begin{tabular}{|c|c|c|c|c|c|c|c|c|c|}
\hline & \multicolumn{3}{|c|}{$2.5 \mathrm{kgs}$} & \multicolumn{3}{|c|}{$5 \mathrm{Kgs}$} & \multicolumn{3}{|c|}{$10 \mathrm{kgs}$} \\
\hline $\begin{array}{l}\text { Test } \\
\text { No } \\
\end{array}$ & $\begin{array}{c}\text { Scratch } \\
\text { Width } \\
\text { mm }\end{array}$ & \begin{tabular}{|l|} 
Wear \\
Volume \\
mm 3 \\
\end{tabular} & \begin{tabular}{|l|} 
Wear \\
Volume \\
Average
\end{tabular} & \begin{tabular}{|c|} 
Scratch \\
Width \\
mm \\
\end{tabular} & \begin{tabular}{|l|} 
Wear \\
Volume \\
m m 3
\end{tabular} & $\begin{array}{l}\text { Wear } \\
\text { Volume } \\
\text { Average }\end{array}$ & $\begin{array}{c}\text { Scratch } \\
\text { Width } \\
\text { m m } \\
\end{array}$ & $\begin{array}{l}\text { Wear } \\
\text { Volume } \\
\text { mm } 3\end{array}$ & $\begin{array}{l}\text { Wear } \\
\text { volume } \\
\text { Average }\end{array}$ \\
\hline 1 & $\mid \begin{array}{l}0.7874 \\
0.7112 \\
0.8128 \\
0.8128 \\
0.6358\end{array}$ & $\begin{array}{l}3.505 \\
z .848 \\
3.740 \\
3.740 \\
\bar{c} .643\end{array}$ & 3.295 & $\begin{array}{l}0.8636 \\
0.9398 \\
1.0922 \\
1.0922 \\
0.9144\end{array}$ & $\begin{array}{l}4.023 \\
5.022 \\
6.805 \\
6.805 \\
4.750\end{array}$ & 5.481 & $\begin{array}{l}1.2700 \\
1.3716 \\
1.3716 \\
0.8636 \\
1.2192\end{array}$ & $\begin{array}{c}9.225 \\
10.771 \\
10.771 \\
4.250 \\
8.496\end{array}$ & 0.695 \\
\hline 2 & $\begin{array}{l}0.7874 \\
0.7874 \\
0.8382 \\
0.8382 \\
0.7874\end{array}$ & $\begin{array}{l}3.505 \\
3.505 \\
3.981 \\
3.981 \\
3.505\end{array}$ & $\begin{array}{c}3.695 \\
.\end{array}$ & $\begin{array}{l}1.1176 \\
1.0160 \\
0.9398 \\
1.0414 \\
0.9906\end{array}$ & $\begin{array}{l}7.129 \\
5.830 \\
5.022 \\
6.181 \\
5.587\end{array}$ & 5.959 & $\begin{array}{l}1.3203 \\
1.2446 \\
1.2700 \\
1.2954 \\
1.3208\end{array}$ & $\begin{array}{l}9.983 \\
8.857 \\
9.220 \\
9.600 \\
9.98\end{array}$ & \\
\hline 3 & $\begin{array}{l}0.81<8 \\
0.8636 \\
0.9144 \\
0.8390 \\
0.9144\end{array}$ & $\begin{array}{l}3.740 \\
4.230 \\
4.750 \\
4.487 \\
4.750\end{array}$ & 4.391 & $\begin{array}{l}1.0414 \\
1.1176 \\
1.0668 \\
1.0668 \\
0.9652\end{array}$ & $\begin{array}{l}6.181 \\
7.129 \\
6.490 \\
0.490 \\
5.500\end{array}$ & 6.318 & $\begin{array}{l}1.2700 \\
1.3970 \\
1.2446 \\
1.1938 \\
1.3716\end{array}$ & $\begin{array}{r}9.225 \\
11.176 \\
0.857 \\
8.145 \\
10.771\end{array}$ & \\
\hline 4 & $\begin{array}{l}0.3636 \\
0.8636 \\
0.9144 \\
0.9144 \\
0.9144\end{array}$ & $\begin{array}{l}4.250 \\
4.230 \\
4.750 \\
4.750 \\
4.750\end{array}$ & 4.542 & $\begin{array}{l}1.1176 \\
1.1176 \\
1.1176 \\
1.0414 \\
1.0414\end{array}$ & $\begin{array}{l}7.129 \\
7.129 \\
7.1=2 \\
6.101 \\
0.181\end{array}$ & $6 . .749$ & $\begin{array}{l}1.3208 \\
1.3208 \\
1.2446 \\
.2954 \\
1.2700\end{array}$ & $\begin{array}{c}9.933 \\
9.933 \\
8.857 \\
9.600 \\
9.225\end{array}$ & 9.529 \\
\hline 5 & $\begin{array}{l}1.0160 \\
1.0160 \\
1.0160 \\
1.0160 \\
.0160\end{array}$ & $\begin{array}{l}5.880 \\
5.830 \\
5.880 \\
5.880 \\
5.880\end{array}$ & 5.880 & $\begin{array}{l}1.1176 \\
1.1176 \\
1.1176 \\
1.0922 \\
1.0922\end{array}$ & $\begin{array}{l}7.129 \\
7.129 \\
7.1<9 \\
6.805 \\
6.805\end{array}$ & 6.999 & $\begin{array}{l}1.3716 \\
1.3716 \\
1.3716 \\
.2192 \\
.2192\end{array}$ & $\begin{array}{c}10.771 \\
10.771 \\
10.771 \\
0.496 \\
8.496\end{array}$ & 9.361 \\
\hline
\end{tabular}


Wear Volume Vs Load

\begin{tabular}{|c|c|c|c|c|c|c|c|c|c|}
\hline & \multicolumn{3}{|c|}{$2.5 \mathrm{kgs}$} & \multicolumn{3}{|c|}{$5 \mathrm{Kgs}$} & \multicolumn{3}{|c|}{$10 \mathrm{Kgs}$} \\
\hline $\begin{array}{l}\text { Test } \\
\text { No }\end{array}$ & $\begin{array}{c}\begin{array}{c}\text { Scratch } \\
\text { Width } \\
\mathrm{mm}\end{array} \\
\end{array}$ & $\begin{array}{c}\text { Wear } \\
\text { Volume } \\
\mathrm{mm} 3\end{array}$ & \begin{tabular}{|l|} 
Wear \\
Volume \\
Average
\end{tabular} & \begin{tabular}{|c|}
$\begin{array}{c}\text { Scratch } \\
\text { Width } \\
\text { mm }\end{array}$ \\
\end{tabular} & \begin{tabular}{|c} 
Wear \\
Volume \\
mm 3
\end{tabular} & $\begin{array}{l}\text { Wear } \\
\text { Volume } \\
\text { Averoge } \\
\end{array}$ & $\begin{array}{l}\text { Scratch } \\
\text { width } \\
\mathrm{mm} \\
\end{array}$ & \begin{tabular}{|l|} 
Wear \\
Volume \\
mm 3 \\
\end{tabular} & \begin{tabular}{|l|} 
Wear \\
Volume \\
Averoge \\
\end{tabular} \\
\hline 1 & $\begin{array}{l}.0922 \\
.9652 \\
.1430 \\
.9144 \\
.0160\end{array}$ & $\begin{array}{l}6.805 \\
5.300 \\
7.459 \\
4.750 \\
5.880\end{array}$ & 5.330 & $\begin{array}{l}1.1938 \\
1.2446 \\
1.2446 \\
1.1936 \\
1.2446\end{array}$ & $\begin{array}{l}8.143 \\
8.857 \\
8.857 \\
3.143 \\
0.857\end{array}$ & 8.571 & $\begin{array}{l}1.7526 \\
1.7526 \\
1.7526 \\
1.6256 \\
1.6256\end{array}$ & $\mid \begin{array}{l}17.627 \\
17.627 \\
17.627 \\
15.156 \\
15.156\end{array}$ & $16.63 \%$ \\
\hline 2 & $\begin{array}{l}1.1176 \\
1.0160 \\
0.9398 \\
1.0414 \\
0.9906\end{array}$ & $\begin{array}{l}7.129 \\
5.880 \\
5.022 \\
6.181 \\
5.587\end{array}$ & 5.9 .59 & $\begin{array}{l}1.3208 \\
1.2446 \\
1.2700 \\
1.2954 \\
1.3208\end{array}$ & $\begin{array}{l}9.985 \\
8.857 \\
9.225 \\
9.600 \\
9.983\end{array}$ & 9.529 & $\begin{array}{l}1.7018 \\
1.4986 \\
1.8034 \\
1.5494 \\
1.6510\end{array}$ & $\begin{array}{l}16.619 \\
12.87 \mathrm{~g} \\
10.667 \\
13.762 \\
15.635\end{array}$ & 13.516 \\
\hline-3 & $\begin{array}{l}0.9906 \\
1.1176 \\
1.1176 \\
1.0160 \\
1.0160\end{array}$ & $\begin{array}{l}5.587 \\
7.129 \\
7.129 \\
5.830 \\
5.380\end{array}$ & 6.321 & $\begin{array}{l}1.1938 \\
1.0922 \\
1.2446 \\
1.2446 \\
1.3208\end{array}$ & $\begin{array}{l}8.143 \\
6.805 \\
8.857 \\
3.857 \\
9.983\end{array}$ & 8.529 & $\begin{array}{l}1.6256 \\
1.6256 \\
1.7526 \\
1.7526 \\
1.7526\end{array}$ & $\begin{array}{l}15.15 \\
15.159 \\
17.627 \\
17.627 \\
17.627\end{array}$ & 16.638 \\
\hline 4 & $\begin{array}{l}1.0414 \\
1.1176 \\
1.0668 \\
1.0668 \\
.9652\end{array}$ & $\begin{array}{l}6.181 \\
7.129 \\
6.490 \\
6.490 \\
5.300\end{array}$ & 6.318 & $\begin{array}{l}1.2700 \\
1.3970 \\
1.2446 \\
1.1938 \\
1.3716\end{array}$ & $\begin{array}{r}9.225 \\
11.176 \\
8.857 \\
0.143 \\
10.771\end{array}$ & 9.634 & $\begin{array}{l}1.5748 \\
1.6256 \\
1.5748 \\
1.5748 \\
1.4732\end{array}$ & $\left|\begin{array}{l}14.219 \\
15.150 \\
14.219 \\
14.219 \\
12.435\end{array}\right|$ & 14.04 \\
\hline 5 & $\begin{array}{l}0.9906 \\
1.0414 \\
1.0414 \\
1.0668 \\
1.0668\end{array}$ & $\begin{array}{l}5.587 \\
6.181 \\
6.181 \\
6.490 \\
6.490\end{array}$ & 6.185 & $\begin{array}{l}1.3208 \\
1.2700 \\
1.2954 \\
1.1938 \\
1.3208\end{array}$ & $\begin{array}{l}9.983 \\
9.225 \\
9.600 \\
8.143 \\
9.983\end{array}$ & 9.387 & $\begin{array}{l}1.7780 \\
1.6784 \\
1.7272 \\
1.7272 \\
1.7272\end{array}$ & $\left|\begin{array}{l}18.14 \\
16.160 \\
17.118 \\
17.118 \\
17.118\end{array}\right|$ & 17.13 \\
\hline
\end{tabular}


Wear Volume Vs Load

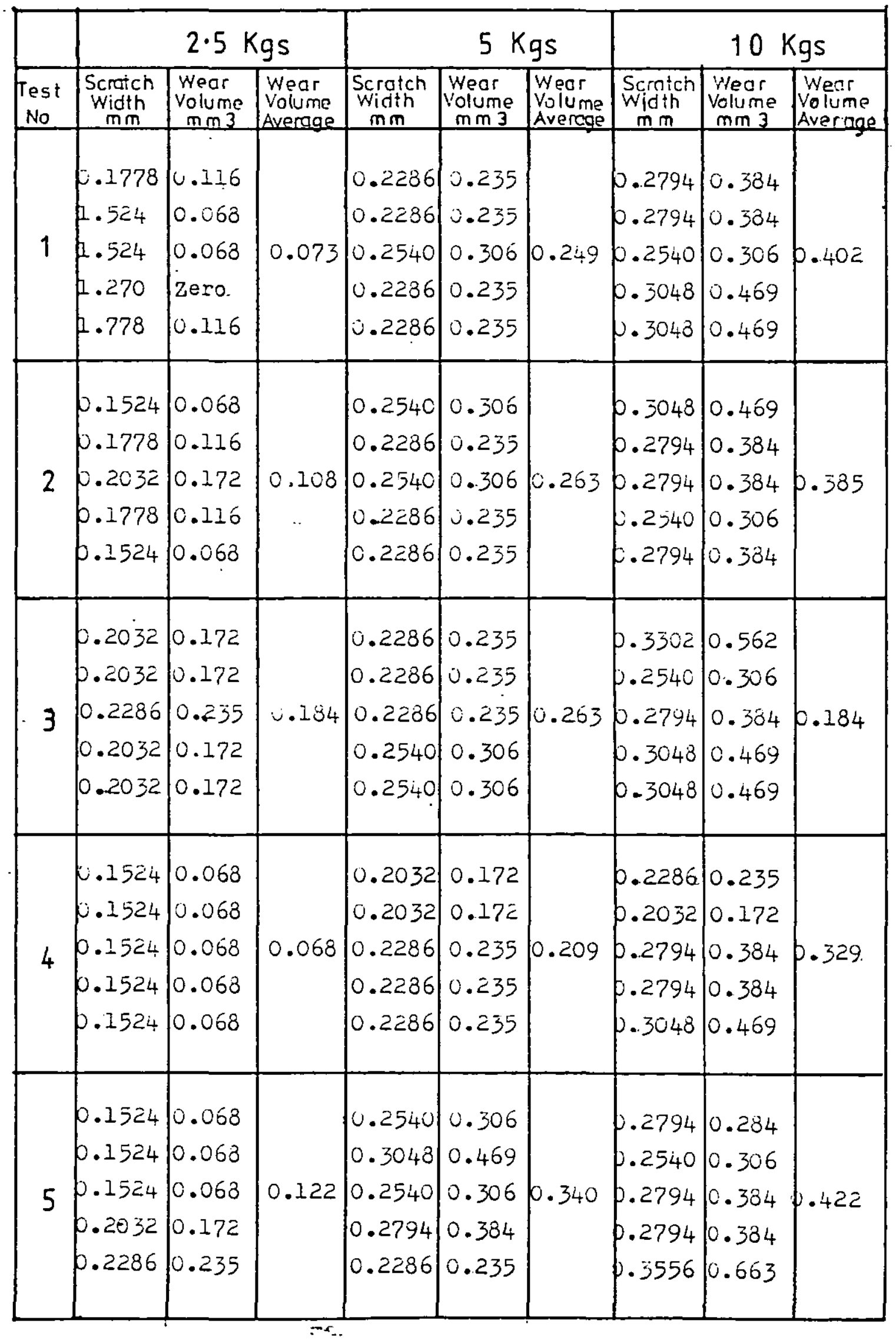


Wear Volume Vs Load

\begin{tabular}{|c|c|c|c|c|c|c|c|c|c|}
\hline & \multicolumn{3}{|c|}{$2.5 \mathrm{kgs}$} & \multicolumn{3}{|c|}{$5 \mathrm{kgs}$} & \multicolumn{3}{|c|}{$10 \mathrm{Kgs}$} \\
\hline $\begin{array}{l}\text { Test } \\
\text { No }\end{array}$ & $\begin{array}{c}\text { Scratch } \\
\text { Width } \\
\mathrm{mm}\end{array}$ & $\begin{array}{l}\text { Wegr } \\
\text { volume } \\
\text { mm } 3\end{array}$ & $\begin{array}{l}\text { Wear } \\
\text { Volume } \\
\text { Average }\end{array}$ & $\begin{array}{l}\text { Scratch } \\
\text { Wirth } \\
\text { mm }\end{array}$ & \begin{tabular}{|l} 
Wear \\
yolume \\
mm 3 \\
\end{tabular} & $\begin{array}{l}\text { Wear } \\
\text { Volume } \\
\text { Average }\end{array}$ & \begin{tabular}{|c|} 
Sirnich \\
width \\
$\mathrm{mm}$
\end{tabular} & \begin{tabular}{|l|} 
Wear \\
volume \\
mm 3 \\
\end{tabular} & $\begin{array}{l}\text { Werr } \\
\text { Volume } \\
\text { Averigge }\end{array}$ \\
\hline 1 & $\left\{\begin{array}{l}0.1524 \\
.1524 \\
.1770 \\
1.270 \\
1.524\end{array}\right.$ & $\begin{array}{l}0.068 \\
u .060 \\
0.116 \\
\text { zero } \\
0.068\end{array}$ & p.064 & $\mid \begin{array}{l}0.2032 \\
0.2032 \\
0.22036 \\
0.22836 \\
0.2<80\end{array}$ & $\begin{array}{l}0.172 \\
0.172 \\
0.235 \\
0.235 \\
0.255\end{array}$ & $0.20 y$ & $\begin{array}{l}.2540 \\
.2540 \\
. \approx 540 \\
.2540 \\
.2540\end{array}$ & $\begin{array}{l}0.306 \\
0.306 \\
0.306 \\
0.306 \\
0.306\end{array}$ & 0.306 \\
\hline 2 & $\begin{array}{l}0.1524 \\
0.1524 \\
0.1524 \\
0.1524 \\
0.1524\end{array}$ & $\begin{array}{l}0.068 \\
0.068 \\
0.068 \\
0.068 \\
0.068\end{array}$ & 0.060 & $\mid \begin{array}{l}0.2038 \\
0.1778 \\
0.2286 \\
0.1778 \\
0.1778\end{array}$ & $\begin{array}{l}0.17 z \\
0.116 \\
0.235 \\
0.116 \\
0.116\end{array}$ & 0.131 & $\left\{\begin{array}{l}. .2794 \\
.2794 \\
.2540 \\
.2340 \\
.2540\end{array}\right.$ & $\begin{array}{l}0.384 \\
0.384 \\
0.306 \\
0.306 \\
0.306\end{array}$ & p. 537 \\
\hline 3 & $\left\{\begin{array}{l}0.1016 \\
.1270 \\
.1016 \\
.076 z \\
.1270\end{array}\right.$ & $\begin{array}{l}\text { zero } \\
\text { zero } \\
\text { zero } \\
\text { zero } \\
\text { zero }\end{array}$ & Zero & $\left|\begin{array}{l}0.1270 \\
0.1016 \\
0.1524 \\
0.1524 \\
0.0162\end{array}\right|$ & $\begin{array}{l}\text { zero } \\
z \in r o \\
0.060 \\
0.068 \\
\text { zero }\end{array}$ & $0.0 z ?$ & $\begin{array}{l}.2794 \\
.3048 \\
.2052 \\
.203 c \\
.2540\end{array}$ & $\begin{array}{l}0.384 \\
0.469 \\
0.172 \\
0.172 \\
0.206\end{array}$ & 300 \\
\hline 4 & $\begin{array}{l}0.15 \approx 4 \\
0.15<4 \\
0.15<4 \\
0.15 \ddot{2} 4 \\
0.15<4\end{array}$ & $\begin{array}{l}0.068 \\
0.068 \\
0.068 \\
0.068 \\
0.060\end{array}$ & 0.068 & $\begin{array}{l}0.2 z 86 \\
0.2 z 86 \\
0.2 z 86 \\
0.2286 \\
0.2286\end{array}$ & $\begin{array}{l}0.235 \\
0.235 \\
0.235 \\
0.235 \\
0.235\end{array}$ & 0.235 & $\begin{array}{l}0.2236 \\
0.2036 \\
0.3048 \\
0.3556 \\
0.1778\end{array}$ & $\begin{array}{l}0.235 \\
0.172 \\
0.462 \\
0.663 \\
0.116\end{array}$ & 10.329 \\
\hline 5 & $\begin{array}{l}0.1016 \\
0.1270 \\
1.1016 \\
1.1016 \\
1.1016\end{array}$ & $\begin{array}{l}\text { Zero } \\
\text { Zero } \\
\text { Zero } \\
\text { Zero } \\
\text { Zero }\end{array}$ & zero & $\begin{array}{l}0.1524 \\
0.1524 \\
0.177 \\
0.1270 \\
0.1524\end{array}$ & $\begin{array}{l}0.068 \\
0.068 \\
0.116 \\
\text { Zero } \\
0.068\end{array}$ & 0.064 & $\begin{array}{l}0.2540 \\
0.2540 \\
0.2540 \\
0.2540 \\
0.2540\end{array}$ & $\begin{array}{l}0.306 \\
0.306 \\
0.306 \\
0.306 \\
0.306\end{array}$ & 0.306 \\
\hline
\end{tabular}


Wear Volume Vs Load

\begin{tabular}{|c|c|c|c|c|c|c|c|c|c|}
\hline & \multicolumn{3}{|c|}{$2.5 \mathrm{kgs}$} & \multicolumn{3}{|c|}{$5 \mathrm{Kgs}$} & \multicolumn{3}{|c|}{$10 \mathrm{kgs}$} \\
\hline $\begin{array}{l}\text { Test } \\
\text { No } \\
\end{array}$ & $\begin{array}{c}\text { Scrotch } \\
\text { Width } \\
\text { mm }\end{array}$ & $\begin{array}{c}\text { Wear } \\
\text { volume } \\
\text { mm3 }\end{array}$ & $\begin{array}{l}\text { Wear } \\
\text { volume } \\
\text { Average }\end{array}$ & $\begin{array}{c}\text { Scratch } \\
\text { width } \\
\text { mm }\end{array}$ & $\begin{array}{l}\text { Wear } \\
\text { Volume } \\
\text { m m } 3\end{array}$ & $\begin{array}{l}\text { Wear } \\
\text { volume } \\
\text { Avercge }\end{array}$ & $\begin{array}{c}\text { Scratch } \\
\text { Wid th } \\
\mathbf{m ~ m} \\
\end{array}$ & $\begin{array}{l}\text { Wear } \\
\text { Volume } \\
\text { mm } 3\end{array}$ & $\begin{array}{l}\text { Wear } \\
\text { Volume } \\
\text { Averange }\end{array}$ \\
\hline 1 & $\left\{\begin{array}{l}.2794 \\
.3048 \\
. \approx 540 \\
.2286 \\
.2540\end{array}\right.$ & $\begin{array}{l}0.384 \\
0.46 y \\
0.306 \\
0.235 \\
0.306\end{array}$ & 0.340 & $\begin{array}{l}0.3048 \\
0.3048 \\
0.3302 \\
0.3810 \\
0.3556\end{array}$ & $\begin{array}{l}0.409 \\
0.469 \\
0.562 \\
0.770 \\
0.663\end{array}$ & 0.586 & $\left\{\begin{array}{l}.4318 \\
.4318 \\
.4318 \\
.4064 \\
.4064\end{array}\right.$ & $\left\{\begin{array}{l}1.008 \\
1.008 \\
1.008 \\
0.386 \\
0.806\end{array}\right.$ & p.959 \\
\hline 2 & $\begin{array}{l}0.4064 \\
0.3556 \\
0.3040 \\
0.3556 \\
0.2794\end{array}$ & $\begin{array}{l}0.886 \\
0.663 \\
0.469 \\
0.663 \\
0.384\end{array}$ & $\begin{array}{c}0.613 \\
. .\end{array}$ & $\begin{array}{l}0.3048 \\
0.3556 \\
0.3556 \\
0.4572 \\
0.5080\end{array}$ & $\begin{array}{l}0.469 \\
0.663 \\
0.663 \\
1.138 \\
1.461\end{array}$ & 0.870 & $\begin{array}{l}0.4572 \\
0.4318 \\
0.4826 \\
0.5334 \\
0.5080\end{array}$ & $\begin{array}{l}1.138 \\
1.008 \\
1.276 \\
1.573 \\
1.421\end{array}$ & 1.283 \\
\hline 3 & $\begin{array}{l}\text { p.2540 } \\
.3048 \\
.2286 \\
.3048 \\
.3048\end{array}$ & $\begin{array}{l}0.306 \\
0.469 \\
0.235 \\
0.469 \\
0.469\end{array}$ & 0.389 & $\begin{array}{l}0.3302 \\
0.2540 \\
0.2032 \\
0.3302 \\
0.4310\end{array}$ & $\begin{array}{l}0.56 z \\
0.306 \\
0.17 z \\
0.50 z \\
1.008\end{array}$ & 0.522 & $\begin{array}{l}p .3810 \\
.5080 \\
.3556 \\
.4064 \\
.4064\end{array}$ & $\begin{array}{l}0.770 \\
1.421 \\
0.663 \\
0.886 \\
0.036\end{array}$ & 0.925 \\
\hline 4 & $\begin{array}{l}0.3048 \\
0.3048 \\
0.3556 \\
0.3810 \\
0.3302\end{array}$ & $\begin{array}{l}0.469 \\
0.469 \\
0.663 \\
0.770 \\
0.502\end{array}$ & 0.586 & $\begin{array}{l}0.3550 \\
0.3080 \\
0.3556 \\
0.3556 \\
0.2032\end{array}$ & $\begin{array}{l}0.663 \\
1.421 \\
0.603 \\
0.663 \\
0.172\end{array}$ & 0.716 & $\left\{\begin{array}{l}.3010 \\
.3556 \\
.4826 \\
.5042 \\
0.4064\end{array}\right.$ & $\begin{array}{l}0.770 \\
0.663 \\
1.270 \\
1.900 \\
0.836\end{array}$ & 1.099 \\
\hline 5 & $\begin{array}{l}0.2794 \\
0.2794 \\
0.2540 \\
0.2540 \\
0.3048\end{array}$ & $\begin{array}{l}0.304 \\
0.384 \\
0.306 \\
0.306 \\
0.462\end{array}$ & 0.360 & $\begin{array}{l}0.3556 \\
0.3536 \\
0.3302 \\
0.3302 \\
0.3048\end{array}$ & $\begin{array}{l}0.603 \\
0.663 \\
0.562 \\
0.562 \\
0.402\end{array}$ & $0.58 z$ & $\begin{array}{l}.4064 \\
.4064 \\
.3048 \\
.4862 \\
.4572\end{array}$ & $\begin{array}{l}0.886 \\
0.386 \\
0.469 \\
1.276 \\
1.138\end{array}$ & 0.931 \\
\hline
\end{tabular}


Wear Volume Vs Load

\begin{tabular}{|c|c|c|c|c|c|c|c|c|c|}
\hline & \multicolumn{3}{|c|}{$2.5 \mathrm{kgs}$} & \multicolumn{3}{|c|}{$5 \mathrm{kgs}$} & \multicolumn{3}{|c|}{$10 \mathrm{kgs}$} \\
\hline \begin{tabular}{|l} 
Test \\
No
\end{tabular} & $\begin{array}{l}\text { Scratch } \\
\text { Width } \\
\text { mm }\end{array}$ & \begin{tabular}{|c|} 
Wear \\
Volume \\
min 3
\end{tabular} & $\begin{array}{l}\text { Wear } \\
\text { Volume } \\
\text { Average }\end{array}$ & $\begin{array}{l}\text { Scratch } \\
\text { Width } \\
\text { mm }\end{array}$ & $\begin{array}{l}\text { Wear } \\
\text { Yolume } \\
\text { m m 3 }\end{array}$ & \begin{tabular}{|l|} 
Weor \\
Volurne \\
Avercoe \\
\end{tabular} & $\begin{array}{c}\text { Scrotch } \\
\text { width } \\
\mathrm{m} \mathrm{m}\end{array}$ & $\begin{array}{l}\text { Wear } \\
\text { Volume } \\
\text { mm } 3 \\
\end{array}$ & $\begin{array}{l}\text { Wear } \\
\text { Volume } \\
\text { Averuge }\end{array}$ \\
\hline 1 & $\begin{array}{l}0.2450 \\
0.2540 \\
0.3048 \\
0.27 y 4 \\
0.3048\end{array}$ & $\begin{array}{l}0.306 \\
0.306 \\
0.402 \\
0.304 \\
0.406\end{array}$ & 0.384 & $\begin{array}{l}0.3556 \\
0.3040 \\
0.3556 \\
0.3502 \\
0.3302\end{array}$ & $\begin{array}{l}0.663 \\
0.462 \\
0.663 \\
0.56 z \\
0.50 z\end{array}$ & 0.582 & $\begin{array}{l}0.3310 \\
0.4064 \\
0.3556 \\
0.3310 \\
0.4318\end{array}$ & $\begin{array}{l}0.770 \\
0.886 \\
0.663 \\
0.770 \\
1.008\end{array}$ & p.819 \\
\hline 2 & $\begin{array}{l}0.2540 \\
p .2540 \\
0.2540 \\
\text { p.2236 } \\
\text { p.2540 }\end{array}$ & $\begin{array}{l}0.306 \\
0.306 \\
0.306 \\
0.235 \\
0.306\end{array}$ & $\begin{array}{c}0.291 \\
.\end{array}$ & $\begin{array}{l}0.3310 \\
0.3302 \\
0.3556 \\
0.3302 \\
0.2794\end{array}$ & $\begin{array}{l}0.386 \\
0.562 \\
0.663 \\
0.562 \\
0.384\end{array}$ & 0.611 & $\begin{array}{l}0.3556 \\
0.3810 \\
0.3810 \\
0.4064 \\
0.3810\end{array}$ & $\begin{array}{l}0.663 \\
0.770 \\
0.770 \\
0.886 \\
0.770\end{array}$ & b.771 \\
\hline 3 & $\begin{array}{l}0.2794 \\
0.2794 \\
0.2540 \\
0.2540 \\
0.2794\end{array}$ & $\begin{array}{l}0.384 \\
0.384 \\
0.306 \\
0.306 \\
0.384\end{array}$ & 0.353 & $\begin{array}{l}0.3556 \\
0.3810 \\
0.3502 \\
0.3048 \\
0.3048\end{array}$ & $\begin{array}{l}0.663 \\
0.770 \\
0.562 \\
0.462 \\
0.462\end{array}$ & 0.583 & $\begin{array}{l}0.3556 \\
0.3550 \\
.4318 \\
.4026 \\
.4064\end{array}$ & $\begin{array}{l}0.663 \\
0.663 \\
1.008 \\
1.276 \\
0.886\end{array}$ & p.899 \\
\hline 4 & $\begin{array}{l}.2540 \\
.2540 \\
.2794 \\
.3048 \\
.3048\end{array}$ & $\begin{array}{l}0.306 \\
0.306 \\
0.384 \\
0.462 \\
0.462\end{array}$ & 0.384 & $\begin{array}{l}0.3048 \\
0.3048 \\
0.3302 \\
0.3556 \\
0.3556\end{array}$ & $\begin{array}{l}0.469 \\
0.469 \\
0.562 \\
0.663 \\
0.603\end{array}$ & 0.565 & $\left\{\begin{array}{l}.4318 \\
.3810 \\
.4318 \\
0.4064 \\
.4064\end{array}\right.$ & $\begin{array}{l}1.008 \\
0.770 \\
1.008 \\
0.886 \\
0.386\end{array}$ & 0.911 \\
\hline 5 & $\begin{array}{l}0.2540 \\
0.2794 \\
0.2794 \\
0.2794 \\
0.3048\end{array}$ & $\begin{array}{l}0.306 \\
0.384 \\
0.384 \\
0.384 \\
0.469\end{array}$ & 0.385 & $\begin{array}{l}0.3302 \\
0.3302 \\
0.3048 \\
0.3048 \\
0.3556\end{array}$ & $\begin{array}{l}0.562 \\
0.56 z \\
0.469 \\
0.46 y \\
0.663\end{array}$ & 0.545 & $\begin{array}{l}0.3530 \\
.3810 \\
0.3810 \\
0.3302 \\
0.4064\end{array}$ & $\begin{array}{l}0.663 \\
0.770 \\
0.770 \\
0.562 \\
0.836\end{array}$ & p.730 \\
\hline
\end{tabular}


Wear Volume Vs Load

\begin{tabular}{|c|c|c|c|c|c|c|c|c|c|}
\hline & \multicolumn{3}{|c|}{$2.5 \mathrm{kgs}$} & \multicolumn{3}{|c|}{$5 \mathrm{Kgs}$} & \multicolumn{3}{|c|}{$10 \mathrm{Kgs}$} \\
\hline \begin{tabular}{|l} 
Test \\
No
\end{tabular} & $\begin{array}{c}\text { Scratch } \\
\text { Width } \\
\mathrm{mm}\end{array}$ & $\begin{array}{l}\text { Wear } \\
\text { Volume } \\
\text { mm } 3\end{array}$ & \begin{tabular}{|l|} 
Wear \\
Volume \\
Average
\end{tabular} & \begin{tabular}{|c|} 
Scratch \\
Widith \\
mm \\
\end{tabular} & \begin{tabular}{|l|} 
Wear \\
Volume \\
mm 3 \\
\end{tabular} & $\begin{array}{l}\text { Wear } \\
\text { Volume } \\
\text { Avercge }\end{array}$ & \begin{tabular}{c|} 
Scrotch \\
width \\
$\mathrm{mm}$ \\
\end{tabular} & $\begin{array}{l}\text { Wear } \\
\text { Volume } \\
\text { mm } 3\end{array}$ & $\begin{array}{l}\text { Wear } \\
\text { Volume } \\
\text { Averige }\end{array}$ \\
\hline 1 & $\begin{array}{l}0.3556 \\
0.3556 \\
.4064 \\
.3048 \\
0.3048\end{array}$ & $\begin{array}{l}u .663 \\
0.663 \\
0.886 \\
0.46 y \\
0.469\end{array}$ & 0.630 & $\begin{array}{l}0.4572 \\
0.4064 \\
0.3810 \\
0.4064 \\
0.5080\end{array}$ & $\begin{array}{l}1.138 \\
0.386 \\
0.770 \\
0.336 \\
1.421\end{array}$ & 1.020 & $\begin{array}{l}0.4318 \\
0.4318 \\
0.4318 \\
0.457 c \\
.5080\end{array}$ & $\begin{array}{l}1.008 \\
1.008 \\
1.008 \\
1.138 \\
1.421\end{array}$ & 1.116 \\
\hline 2 & $\begin{array}{l}0.2540 \\
.2794 \\
.3048 \\
.3048 \\
.3048\end{array}$ & $\begin{array}{l}0.306 \\
0.384 \\
0.469 \\
0.469 \\
0.469\end{array}$ & $\begin{array}{c}0.419 \\
.\end{array}$ & $\begin{array}{l}0.3556 \\
0.4064 \\
0.3310 \\
u .3810 \\
0.3302\end{array}$ & $\begin{array}{l}0.663 \\
0.886 \\
0.770 \\
0.770 \\
0.562\end{array}$ & 0.730 & $\begin{array}{l}.4318 \\
.3810 \\
.4318 \\
.4064 \\
.4064\end{array}$ & $\begin{array}{l}1.008 \\
0.770 \\
1.008 \\
0.886 \\
0.386\end{array}$ & 0.911 \\
\hline 3 & $\begin{array}{l}0.3048 \\
.3556 \\
.3302 \\
0.3556 \\
0.3048\end{array}$ & $\begin{array}{l}0.469 \\
0.603 \\
0.502 \\
0.663 \\
0.469\end{array}$ & 0.565 & $\begin{array}{l}0.4064 \\
0.4318 \\
0.4572 \\
0.3810 \\
0.3302\end{array}$ & $\begin{array}{l}0.886 \\
1.008 \\
1.138 \\
0.770 \\
0.562\end{array}$ & 0.873 & $\left\{\begin{array}{l}.4318 \\
.4064 \\
.5588 \\
0.5080 \\
0.5080\end{array}\right.$ & $\begin{array}{l}1.008 \\
0.886 \\
1.733 \\
1.421 \\
1.421\end{array}$ & .293 \\
\hline 4 & $\begin{array}{l}0.2794 \\
0.3302 \\
0.3048 \\
0.5048 \\
0.2540\end{array}$ & $\begin{array}{l}0.384 \\
0.562 \\
0.469 \\
0.469 \\
0.306\end{array}$ & 0.438 & $\begin{array}{l}0.4064 \\
0.4318 \\
0.4064 \\
0.3556 \\
0.3556\end{array}$ & $\begin{array}{l}0.886 \\
1.008 \\
0.886 \\
0.663 \\
0.663\end{array}$ & 0.821 & $\begin{array}{l}0.4826 \\
.4572 \\
.4826 \\
.4572 \\
.5472\end{array}$ & $\begin{array}{l}1.276 \\
1.138 \\
1.276 \\
1.138 \\
1.138\end{array}$ & 1.193 \\
\hline 5 & $\begin{array}{l}0.2794 \\
0.2794 \\
0.2794 \\
0.2784 \\
0.2794\end{array}$ & $\begin{array}{l}0.384 \\
0.384 \\
0.384 \\
0.384 \\
0.384\end{array}$ & 0.384 & $\begin{array}{l}0.3810 \\
0.3810 \\
0.3302 \\
0.3302 \\
0.3302\end{array}$ & $\begin{array}{l}0.770 \\
0.770 \\
0.562 \\
0.562 \\
0.562\end{array}$ & 0.645 & $\begin{array}{l}.4318 \\
.4318 \\
.4318 \\
.4318 \\
.4318\end{array}$ & $\begin{array}{l}1.008 \\
1.008 \\
1.008 \\
1.008 \\
1.008\end{array}$ & 1.008 \\
\hline
\end{tabular}


Wear Volume Vs Load

\begin{tabular}{|c|c|c|c|c|c|c|c|c|c|}
\hline & \multicolumn{3}{|c|}{$2.5 \mathrm{kgs}$} & \multicolumn{3}{|c|}{$5 \mathrm{KgS}$} & \multicolumn{3}{|c|}{$10 \mathrm{Kgs}$} \\
\hline $\begin{array}{l}\text { Test } \\
\text { No } \\
\end{array}$ & \begin{tabular}{|c|}
$\begin{array}{c}\text { Scratich } \\
\text { Width } \\
\text { mm }\end{array}$ \\
\end{tabular} & \begin{tabular}{|c|} 
Wear \\
volumo \\
mom 3
\end{tabular} & $\begin{array}{l}\text { Wear } \\
\text { Volume } \\
\text { Average }\end{array}$ & \begin{tabular}{|c|} 
Scratch \\
Width \\
mm \\
\end{tabular} & $\begin{array}{l}\text { Wear } \\
\text { Yolume } \\
\text { mm } 3 \\
\end{array}$ & $\begin{array}{l}\text { Wear } \\
\text { Volume } \\
\text { Avercge }\end{array}$ & \begin{tabular}{|c|} 
Scratch \\
width \\
m m \\
\end{tabular} & \begin{tabular}{|l|} 
Wear \\
volume \\
mm 3 \\
\end{tabular} & $\begin{array}{l}\text { Verr } \\
\text { Volume } \\
\text { Averige }\end{array}$ \\
\hline 1 & $\begin{array}{l}0.2540 \\
0.3048 \\
0.2794 \\
0.2540 \\
0.2286\end{array}$ & $\begin{array}{l}0.306 \\
0.469 \\
0.384 \\
0.306 \\
0.235\end{array}$ & 0.340 & $\begin{array}{l}0.3302 \\
0.3556 \\
0.4318 \\
0.3556 \\
0.3048\end{array}$ & $\begin{array}{l}0.562 \\
0.663 \\
1.008 \\
0.663 \\
0.469\end{array}$ & 0.073 & $\begin{array}{l}0.4064 \\
0.35 j 0 \\
0.3810 \\
0.4826 \\
0.3810\end{array}$ & $\begin{array}{l}0.386 \\
0.663 \\
0.770 \\
1.276 \\
0.770\end{array}$ & 0.873 \\
\hline 2 & $\begin{array}{l}0.2794 \\
0.3302 \\
0.304 \varepsilon \\
0.2794 \\
0.3556\end{array}$ & $\begin{array}{l}0.384 \\
0.562 \\
0.464 \\
0.384 \\
0.663\end{array}$ & 0.492 & $\begin{array}{l}0.4572 \\
0.4326 \\
0.3810 \\
0.3556 \\
0.3048\end{array}$ & $\begin{array}{l}1.138 \\
1.276 \\
0.770 \\
0.663 \\
0.469\end{array}$ & 0.863 & $\begin{array}{l}0.3556 \\
0.3810 \\
0.4572 \\
0.4572 \\
0.5030\end{array}$ & $\begin{array}{l}0.663 \\
0.770 \\
1.138 \\
1.138 \\
1.421\end{array}$ & 1.026 \\
\hline 3 & $\begin{array}{l}0.1524 \\
0.2540 \\
0.1778 \\
0.1778 \\
0.2032\end{array}$ & $\begin{array}{l}0.068 \\
0.306 \\
0.116 \\
0.116 \\
0.172\end{array}$ & 0.155 & $\begin{array}{l}0.2540 \\
0.3048 \\
0.2286 \\
0.2540 \\
0.2794\end{array}$ & $\begin{array}{l}0.306 \\
0.469 \\
0.235 \\
0.306 \\
0.384\end{array}$ & 10.340 & $\left\{\begin{array}{l}3302 \\
.3048 \\
.4572 \\
.4572 \\
.3550\end{array}\right.$ & $\begin{array}{l}0.562 \\
0.469 \\
1.138 \\
1.138 \\
0.663\end{array}$ & p.794 \\
\hline 4 & $\begin{array}{l}.2540 \\
0.2540 \\
0.2794 \\
.3048 \\
.3048\end{array}$ & $\begin{array}{l}0.306 \\
0.306 \\
0.384 \\
0.462 \\
0.462\end{array}$ & 0.384 & $\begin{array}{l}0.3048 \\
0.3556 \\
0.330 z \\
0.3556 \\
0.3048\end{array}$ & $\begin{array}{l}0.469 \\
0.663 \\
0.562 \\
0.663 \\
0.469\end{array}$ & 0.565 & $\begin{array}{l}.4064 \\
.4318 \\
.4572 \\
.3810 \\
.3302\end{array}$ & $\begin{array}{l}0.386 \\
1.008 \\
1.138 \\
0.770 \\
0.562\end{array}$ & 0.873 \\
\hline 5 & $\begin{array}{l}0.3048 \\
.3302 \\
.2794 \\
0.2794 \\
.3556\end{array}$ & $\begin{array}{l}0.469 \\
0.562 \\
0.384 \\
0.384 \\
0.663\end{array}$ & 0.492 & $\begin{array}{l}0.4064 \\
0.4318 \\
0.3810 \\
0.4064 \\
0.3556\end{array}$ & $\begin{array}{l}0.886 \\
1.008 \\
0.770 \\
0.886 \\
0.663\end{array}$ & 0.819 & $\begin{array}{l}.4572 \\
.4318 \\
.5334 \\
.5588 \\
.4064\end{array}$ & $\begin{array}{l}1.138 \\
1.008 \\
1.573 \\
1.733 \\
0.886\end{array}$ & 1.267 \\
\hline
\end{tabular}


Wear Volume Vs Load

\begin{tabular}{|c|c|c|c|c|c|c|c|c|c|}
\hline & \multicolumn{3}{|c|}{$2.5 \mathrm{kgs}$} & \multicolumn{3}{|c|}{$5 \mathrm{kgs}$} & \multicolumn{3}{|c|}{$10 \mathrm{Kgs}$} \\
\hline $\begin{array}{l}\text { Test } \\
\text { No } \\
\end{array}$ & \begin{tabular}{|c|} 
Scratch \\
Width \\
mm
\end{tabular} & $\begin{array}{l}\text { Wear } \\
\text { Volume } \\
\text { mm } 3 \\
\end{array}$ & \begin{tabular}{|l|} 
Wear \\
Volume \\
Average
\end{tabular} & $\begin{array}{c}\text { Scratch } \\
\text { Width } \\
\text { mm } \\
\end{array}$ & $\begin{array}{l}\text { Wear } \\
\text { Volume } \\
\text { m m } 3 \\
\end{array}$ & \begin{tabular}{|l|} 
Wear \\
Volume \\
Avercge
\end{tabular} & \begin{tabular}{|c|} 
Scratch \\
Width \\
$\mathbf{m} \mathrm{m}$ \\
\end{tabular} & $\begin{array}{l}\text { Wear } \\
\text { Volume } \\
\text { mm } 3 \\
\end{array}$ & $\begin{array}{l}\text { Wear } \\
\text { Volume } \\
\text { Average }\end{array}$ \\
\hline 1 & $\begin{array}{l}0.3302 \\
0.3810 \\
0.4572 \\
0.4572 \\
0.4318\end{array}$ & $\begin{array}{l}0.562 \\
0.770 \\
1.138 \\
1.158 \\
1.008\end{array}$ & 0.923 & $\begin{array}{l}0.6050 \\
0.6096 \\
0.7874 \\
0.7874 \\
0.6850\end{array}$ & $\begin{array}{l}2.643 \\
2.075 \\
3.437 \\
3.437 \\
2.643\end{array}$ & 2.037 & $\mid \begin{array}{c}0.6604 \\
0.6604 \\
0.8123 \\
0.7874 \\
0.6604\end{array}$ & $\begin{array}{l}2.446 \\
2.446 \\
3.740 \\
3.437 \\
2.446\end{array}$ & 2.903 \\
\hline 2 & $\begin{array}{l}0.5334 \\
0.7366 \\
0.5538 \\
0.6096 \\
0.5030\end{array}$ & $\begin{array}{l}1.573 \\
3.060 \\
1.733 \\
2.075 \\
1.421\end{array}$ & $\begin{array}{c}1 . y 7 z \\
. .\end{array}$ & $\begin{array}{l}0.5354 \\
0.711 z \\
1.0922 \\
0.6858 \\
0.5842\end{array}$ & $\begin{array}{l}1.573 \\
2.848 \\
6.005 \\
2.643 \\
1.900\end{array}$ & 3.154 & $\mid \begin{array}{l}0.8582 \\
1.0160 \\
0.9390 \\
0.3890 \\
0.8636\end{array}$ & $\begin{array}{l}3.981 \\
5.880 \\
5.022 \\
4.487 \\
4.230\end{array}$ & 4.720 \\
\hline 3 & $\begin{array}{l}0.5334 \\
0.5334 \\
0.5334 \\
0.6550 \\
0.6604\end{array}$ & $\begin{array}{l}1.573 \\
1.573 \\
1.573 \\
2.272 \\
2.446\end{array}$ & 1.087 & $\begin{array}{l}0.6858 \\
u .3128 \\
0.7620 \\
u .7620 \\
0.5842\end{array}$ & $\begin{array}{l}2.643 \\
3.740 \\
3.279 \\
3.279 \\
1.900\end{array}$ & 2.968 & $\begin{array}{l}.7874 \\
.7874 \\
.8332 \\
.8382 \\
.8332\end{array}$ & $\begin{array}{l}3.437 \\
3.437 \\
3.981 \\
3.901 \\
3.981\end{array}$ & 3.763 \\
\hline 4 & $\begin{array}{l}0.5334 \\
0.5354 \\
0.5030 \\
0.4826 \\
0.6350\end{array}$ & $\begin{array}{l}1.573 \\
1.573 \\
1.421 \\
1.276 \\
2.272\end{array}$ & 1.623 & $\begin{array}{l}0.6350 \\
0.6350 \\
0.6858 \\
0.6604 \\
0.7620\end{array}$ & $\begin{array}{l}2 . \dot{c} 7 \ddot{c} \\
\ddot{c} .27 z \\
2.643 \\
2.446 \\
3.279\end{array}$ & 2.582 & 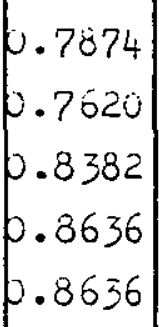 & $\begin{array}{l}3.437 \\
3.27 y \\
5.981 \\
4.230 \\
4.230\end{array}$ & 3.831 \\
\hline 5 & $\begin{array}{l}0.4026 \\
0.4826 \\
0.5588 \\
0.5842 \\
0.5354\end{array}$ & $\begin{array}{l}1.276 \\
1.276 \\
1.733 \\
1.900 \\
1.573\end{array}$ & 1.551 & $\begin{array}{l}0.7366 \\
0.5281 \\
0.7366 \\
0.7366 \\
0.5334\end{array}$ & $\begin{array}{l}3.060 \\
1.733 \\
3.060 \\
3.060 \\
1.573\end{array}$ & 2.497 & $\begin{array}{r}.9398 \\
.6604 \\
.6004 \\
.8382 \\
.8382\end{array}$ & $\begin{array}{l}5.022 \\
2.446 \\
2.446 \\
3.981 \\
3.981\end{array}$ & 3.575 \\
\hline
\end{tabular}


Wear Volume Vs Load

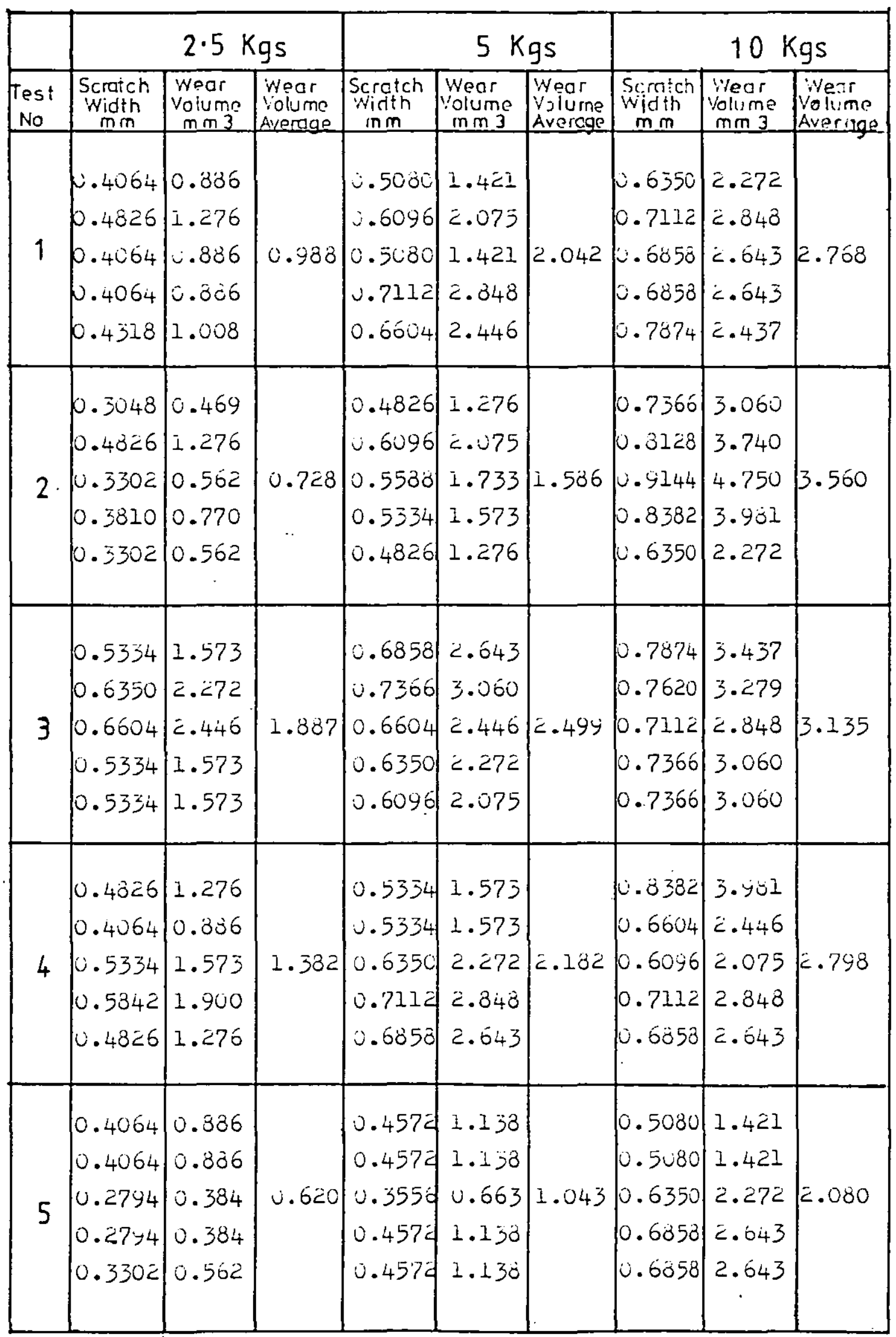


Wear Volume Vs Load

\begin{tabular}{|c|c|c|c|c|c|c|c|c|c|}
\hline & \multicolumn{3}{|c|}{$2.5 \mathrm{kgs}$} & \multicolumn{3}{|c|}{$5 \mathrm{kgs}$} & \multicolumn{3}{|c|}{$10 \mathrm{kgs}$} \\
\hline $\begin{array}{l}\text { Test } \\
\text { No }\end{array}$ & \begin{tabular}{|c|} 
Scratch \\
Width \\
$\mathrm{mm}$
\end{tabular} & \begin{tabular}{|l} 
Wear \\
volume \\
mm 3
\end{tabular} & \begin{tabular}{|l|} 
Wear \\
Volume \\
Avergge
\end{tabular} & \begin{tabular}{|c|}
$\begin{array}{c}\text { Scratch } \\
\text { Width } \\
\text { mm } \\
\end{array}$ \\
\end{tabular} & \begin{tabular}{|l|} 
Wear \\
Volume \\
min 3 \\
\end{tabular} & $\begin{array}{l}\text { Wear } \\
\text { Volume } \\
\text { Average } \\
\end{array}$ & \begin{tabular}{|c|} 
Scratch \\
width \\
$\mathrm{mm}$ \\
\end{tabular} & \begin{tabular}{|l|} 
Wear \\
Volume \\
mm 3 \\
\end{tabular} & \begin{tabular}{|l|} 
Wear \\
Volume \\
Average \\
\end{tabular} \\
\hline 1 & $\begin{array}{l}0.1524 \\
0.1524 \\
0.1778 \\
0.1778 \\
0.2032\end{array}$ & $\begin{array}{l}0.068 \\
0.068 \\
0.116 \\
0.116 \\
0.172\end{array}$ & 0.108 & $\begin{array}{l}0.2286 \\
0.2286 \\
0.2236 \\
ن . z 549 \\
0.254 i\end{array}$ & $\begin{array}{l}0.235 \\
0.235 \\
0.235 \\
0.306 \\
0.306\end{array}$ & 0.263 & $\mid \begin{array}{l}0.3556 \\
0.3302 \\
0.2794 \\
0.2794 \\
0.2540\end{array}$ & $\begin{array}{l}0.663 \\
0.56 \bar{z} \\
0.384 \\
0.384 \\
0.306\end{array}$ & 0.459 \\
\hline 2 & $\begin{array}{l}0.2286 \\
0.2286 \\
0.2286 \\
0.2540 \\
0.2794\end{array}$ & $\begin{array}{l}0.235 \\
0.235 \\
0.235 \\
0.306 \\
0.384\end{array}$ & 0.279 & $\begin{array}{l}0.3556 \\
0.3504 \\
0.2794 \\
0.2794 \\
0.2540\end{array}$ & $\begin{array}{l}0.663 \\
0.562 \\
0.384 \\
0.384 \\
0.306\end{array}$ & 0.459 & $\left|\begin{array}{l}0.2286 \\
0.2540 \\
0.4826 \\
0.4826 \\
0.4826\end{array}\right|$ & $\begin{array}{l}0.235 \\
0.306 \\
1.276 \\
1.276 \\
1.276\end{array}$ & 0.874 \\
\hline 3 & $\mid \begin{array}{l}0.2032 \\
0.2032 \\
0.2032 \\
0.2032 \\
0.2286\end{array}$ & $\begin{array}{l}0.172 \\
0.172 \\
0.172 \\
0.172 \\
0.235\end{array}$ & $ن .184$ & $\begin{array}{l}0.2286 \\
0.2236 \\
0.2540 \\
0.2549 \\
0.2286\end{array}$ & $\begin{array}{l}0.235 \\
0.235 \\
0.306 \\
0.306 \\
0.235\end{array}$ & 0.263 & $\mid \begin{array}{l}0.2794 \\
0.4064 \\
0.3550 \\
0.4318 \\
0.3302\end{array}$ & $\begin{array}{l}0.384 \\
0.086 \\
0.603 \\
1.008 \\
0.502\end{array}$ & 0.688 \\
\hline 4 & $\mid \begin{array}{l}0.1524 \\
0.1524 \\
0.1778 \\
0.1778 \\
0.2032\end{array}$ & $\begin{array}{l}0.068 \\
0.068 \\
0.116 \\
0.116 \\
0.172\end{array}$ & 0.108 & $\begin{array}{l}0.2286 \\
0.2286 \\
0.2286 \\
0.2236 \\
0.2236\end{array}$ & $\begin{array}{l}0.235 \\
0.235 \\
0.235 \\
0.235 \\
0.235\end{array}$ & 0.235 & $\mid \begin{array}{l}0.2794 \\
0.2794 \\
0.2794 \\
0.2794 \\
0.2794\end{array}$ & $\begin{array}{l}0.384 \\
0.384 \\
0.384 \\
0.384 \\
0.384\end{array}$ & 0.384 \\
\hline 5 & $\begin{array}{l}0.1524 \\
0.1524 \\
0.1778 \\
0.1778 \\
0.2032\end{array}$ & $\begin{array}{l}0.068 \\
0.068 \\
0.116 \\
0.116 \\
0.17 z\end{array}$ & 0.108 & $\begin{array}{l}0.2286 \\
0.2236 \\
0.2286 \\
0.2549 \\
0.2549\end{array}$ & $\begin{array}{l}0.235 \\
0.235 \\
0.235 \\
0.306 \\
0.306\end{array}$ & 0.263 & $\mid \begin{array}{l}0.3302 \\
0.3048 \\
0.3048 \\
0.2540 \\
0.2794\end{array}$ & $\begin{array}{l}0.562 \\
0.469 \\
0.469 \\
0.306 \\
0.384\end{array}$ & 10.438 \\
\hline
\end{tabular}


Wear Volume Vs Load

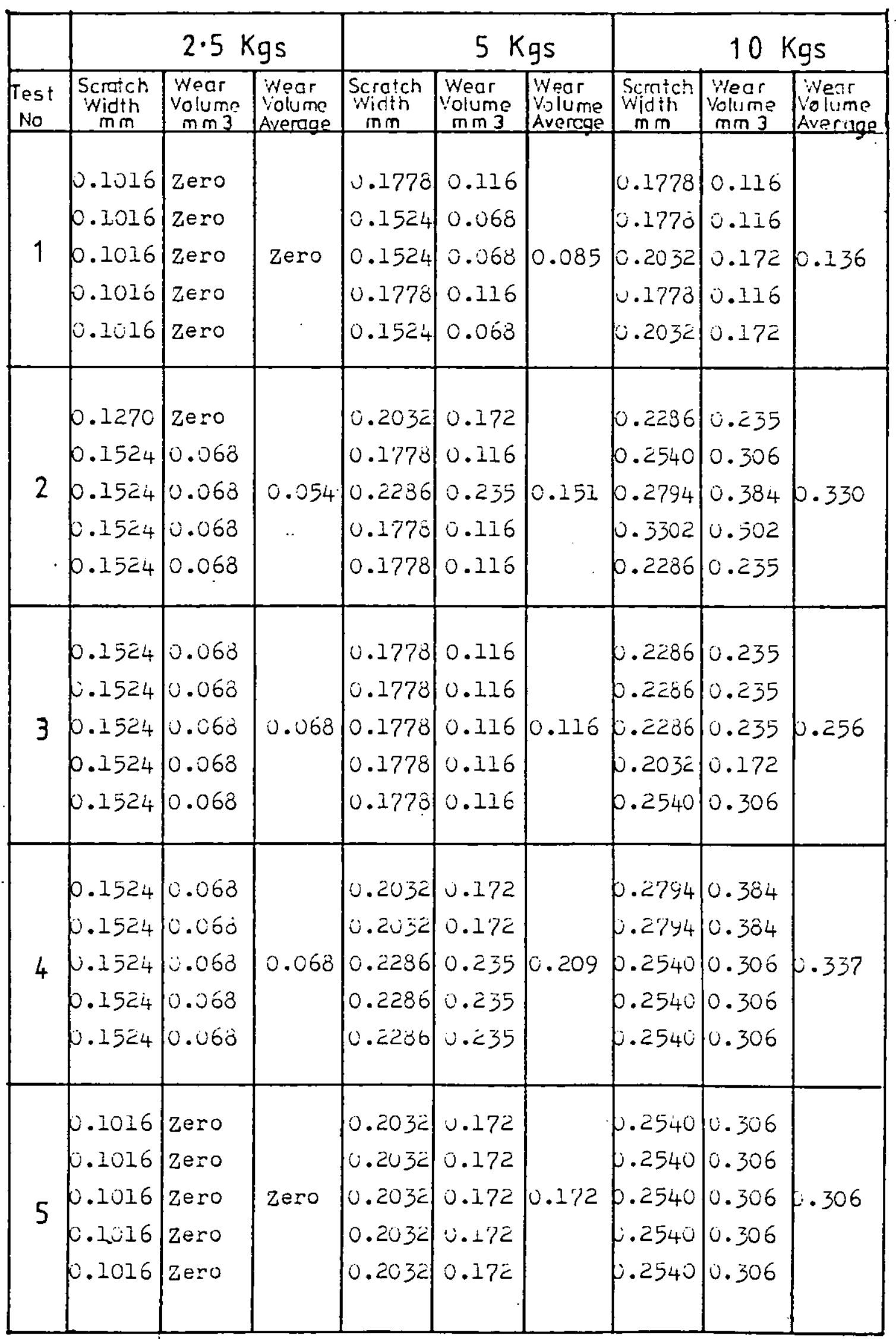


Wear Volume Vs Load

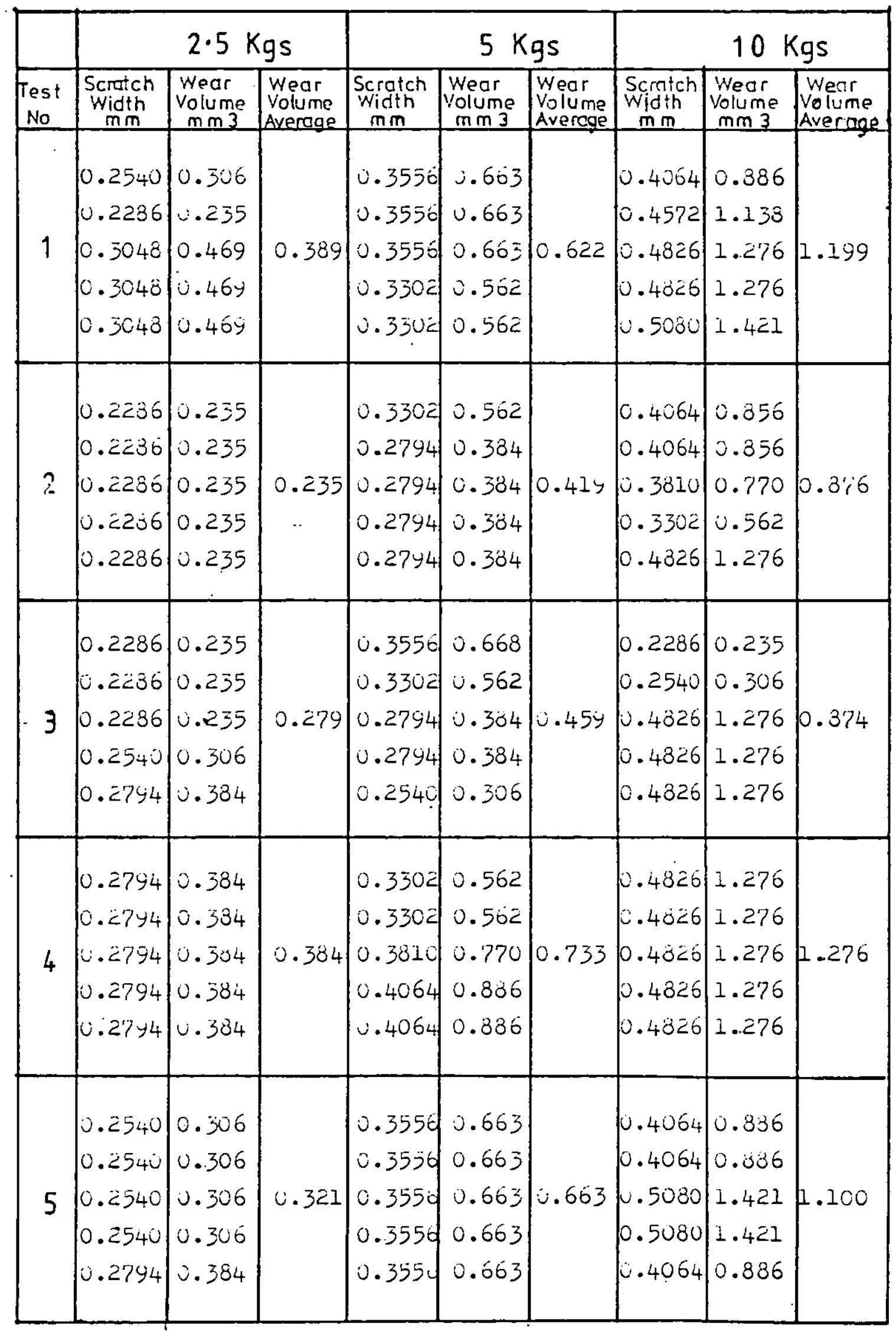


Wear Volume Vs Load

\begin{tabular}{|c|c|c|c|c|c|c|c|c|c|}
\hline & \multicolumn{3}{|c|}{$2.5 \mathrm{kgs}$} & \multicolumn{3}{|c|}{$5 \mathrm{kgs}$} & \multicolumn{3}{|c|}{$10 \mathrm{Kgs}$} \\
\hline $\begin{array}{l}\text { Test } \\
\text { No } \\
\end{array}$ & $\begin{array}{c}\text { Scratch } \\
\text { width } \\
\text { min }\end{array}$ & \begin{tabular}{|c|} 
Wear \\
Volume \\
m m 3 \\
\end{tabular} & $\begin{array}{l}\text { Wear } \\
\text { volume } \\
\text { Average }\end{array}$ & $\begin{array}{l}\text { Scratch } \\
\text { width } \\
\text { mm }\end{array}$ & $\begin{array}{l}\text { Wear } \\
\text { yolume } \\
\text { m m 3 } \\
\end{array}$ & $\begin{array}{l}\text { Wear } \\
\text { Volume } \\
\text { Avercoge }\end{array}$ & \begin{tabular}{|c|} 
Scratch \\
wijdth \\
mm
\end{tabular} & $\begin{array}{l}\text { Vear } \\
\text { volume } \\
\text { mm } 3\end{array}$ & $\begin{array}{l}\text { Weri } \\
\text { Volume } \\
\text { Averinge }\end{array}$ \\
\hline 1 & $\mid \begin{array}{l}0.2032 \\
0.2032 \\
0.2286 \\
0.2286 \\
0.2540\end{array}$ & $\begin{array}{l}0.172 \\
0.172 \\
0.235 \\
0.235 \\
0.306\end{array}$ & 0.224 & $\begin{array}{l}0.3556 \\
0.2794 \\
0.3810 \\
0.3048 \\
0.2794\end{array}$ & $\begin{array}{l}0.603 \\
0.384 \\
0.770 \\
0.469 \\
0.384\end{array}$ & 0.534 & $\left|\begin{array}{l}0.4064 \\
0.3048 \\
0.3810 \\
0.4318 \\
0.4572\end{array}\right|$ & $\begin{array}{l}0.806 \\
0.469 \\
0.770 \\
1.008 \\
1.138\end{array}$ & 0.354 \\
\hline 2 & $\begin{array}{l}0.2794 \\
0.2540 \\
0.2794 \\
0.2540 \\
0.2794\end{array}$ & $\begin{array}{l}0.384 \\
0.306 \\
0.384 \\
0.306 \\
0.384\end{array}$ & $\begin{array}{c}0.353 \\
. .\end{array}$ & $\begin{array}{l}0.3556 \\
0.330 \\
0.3048 \\
0.3048 \\
0.3810\end{array}$ & $\begin{array}{l}0.603 \\
0.562 \\
0.462 \\
0.462 \\
0.770\end{array}$ & 0.583 & $\mid \begin{array}{l}0.4064 \\
0.4064 \\
0.3556 \\
0.3550 \\
0.4572\end{array}$ & $\begin{array}{l}0.386 \\
0.386 \\
0.663 \\
0.663 \\
1.138\end{array}$ & 0.847 \\
\hline 3 & $\begin{array}{l}0.2032 \\
0.2286 \\
0.2286 \\
0.2540 \\
0.2540\end{array}$ & $\begin{array}{l}0.172 \\
0.235 \\
0.235 \\
0.306 \\
0.306\end{array}$ & 0.249 & $\begin{array}{l}0.3302 \\
0.3302 \\
0.3556 \\
0.3048 \\
0.3048\end{array}$ & $\begin{array}{l}0.562 \\
0.562 \\
0.663 \\
0.469 \\
0.469\end{array}$ & 0.545 & $\begin{array}{l}0.4064 \\
0.4318 \\
0.4064 \\
0.3556 \\
0.3556\end{array}$ & $\begin{array}{l}0.886 \\
1.008 \\
0.886 \\
0.663 \\
0.663\end{array}$ & 0.321 \\
\hline 4 & $\begin{array}{l}0.2286 \\
0.2236 \\
0.2540 \\
0.2794 \\
0.2794\end{array}$ & $\begin{array}{l}0.235 \\
0.235 \\
0.306 \\
0.384 \\
0.384\end{array}$ & 0.303 & $\begin{array}{l}0.3302 \\
0.3048 \\
0.3048 \\
0.3556 \\
0.3810\end{array}$ & $\begin{array}{l}0.562 \\
0.462 \\
0.462 \\
0.663 \\
0.770\end{array}$ & 0.583 & $\mid \begin{array}{l}0.3010 \\
0.3010 \\
0.4064 \\
0.4064 \\
0.4572\end{array}$ & $\begin{array}{l}0.770 \\
0.770 \\
0.886 \\
0.886 \\
1.138\end{array}$ & 0.390 \\
\hline 5 & $\begin{array}{l}0.3048 \\
0.2540 \\
0.3048 \\
0.2794 \\
u .3048\end{array}$ & $\begin{array}{l}0.469 \\
0.306 \\
0.469 \\
0.384 \\
0.469\end{array}$ & 0.419 & $\begin{array}{l}0.3556 \\
0.3556 \\
0.3048 \\
0.4064 \\
0.3048\end{array}$ & $\begin{array}{l}0.663 \\
0.663 \\
0.469 \\
0.886 \\
0.469\end{array}$ & 0.630 & $\begin{array}{l}0.330 z \\
0.4318 \\
0.4572 \\
0.4572 \\
0.4572\end{array}$ & $\begin{array}{l}0.562 \\
1.008 \\
1.138 \\
1.138 \\
1.138\end{array}$ & 0.997 \\
\hline
\end{tabular}


Wear Volume Vs Load

\begin{tabular}{|c|c|c|c|c|c|c|c|c|c|}
\hline & \multicolumn{3}{|c|}{$2.5 \mathrm{kgs}$} & \multicolumn{3}{|c|}{$5 \mathrm{kgs}$} & \multicolumn{3}{|c|}{$10 \mathrm{kgs}$} \\
\hline $\begin{array}{l}\text { Test } \\
\text { No } \\
\end{array}$ & $\begin{array}{c}\text { Scratch } \\
\text { Width } \\
\text { mm }\end{array}$ & \begin{tabular}{|l} 
Wear \\
Volume \\
mm?
\end{tabular} & \begin{tabular}{|l|} 
Wear \\
Volume \\
Average \\
\end{tabular} & $\begin{array}{l}\text { Scratch } \\
\text { Width } \\
\text { inm }\end{array}$ & \begin{tabular}{|l|} 
Wear \\
Volume \\
mm 3 \\
\end{tabular} & $\begin{array}{l}\text { Wear } \\
\text { Volume } \\
\text { Avercoe }\end{array}$ & $\begin{array}{c}\text { Scratch } \\
\text { width } \\
\mathrm{mm}\end{array}$ & $\begin{array}{l}\text { Wear } \\
\text { Volume } \\
\text { mm } 3\end{array}$ & $\begin{array}{l}\text { Wear } \\
\text { Volume } \\
\text { Average }\end{array}$ \\
\hline 1 & $\begin{array}{l}0.3048 \\
0.4084 \\
0.3302 \\
0.3302 \\
0.3302\end{array}$ & $\begin{array}{l}0.469 \\
0.386 \\
0.562 \\
0.562 \\
0.562\end{array}$ & 0.608 & $\begin{array}{l}0.3302 \\
0.4310 \\
0.4826 \\
0.3310 \\
0.3810\end{array}$ & $\begin{array}{l}0.562 \\
1.008 \\
1.276 \\
0.770 \\
0.770\end{array}$ & 0.377 & $\begin{array}{l}0.4026 \\
u .4318 \\
0.4318 \\
0.5334 \\
0.5080\end{array}$ & $\begin{array}{l}1.276 \\
1.008 \\
1.008 \\
1.573 \\
1.421\end{array}$ & 1.257 \\
\hline 2. & $\begin{array}{l}0.3302 \\
0.2540 \\
0.2794 \\
0.27 \% 4 \\
0.2794\end{array}$ & $\begin{array}{l}0.562 \\
0.306 \\
0.384 \\
0.384 \\
0.304\end{array}$ & $\begin{array}{c}0.404 \\
. .\end{array}$ & $\begin{array}{l}0.2794 \\
0.3556 \\
0.3506 \\
0.3810 \\
0.3556\end{array}$ & $\begin{array}{l}0.384 \\
0.663 \\
0.562 \\
0.770 \\
0.663\end{array}$ & 0.603 & $\begin{array}{l}0.5080 \\
0.5080 \\
0.3556 \\
0.4064 \\
0.4064\end{array}$ & $\begin{array}{l}1.421 \\
1.421 \\
0.665 \\
0.836 \\
0.886\end{array}$ & 1.055 \\
\hline 3 & $\begin{array}{l}0.2286 \\
0.2286 \\
0.2540 \\
0.2286 \\
0.2286\end{array}$ & $\begin{array}{l}0.235 \\
0.235 \\
0.306 \\
0.235 \\
0.235\end{array}$ & 0.249 & $\begin{array}{l}0.2540 \\
0.2540 \\
0.3048 \\
0.3048 \\
0.2794\end{array}$ & $\begin{array}{l}0.306 \\
0.306 \\
0.469 \\
0.469 \\
0.384\end{array}$ & 0.395 & $\begin{array}{l}0.3048 \\
0.4826 \\
0.5080 \\
0.4064 \\
0.3810\end{array}$ & $\begin{array}{l}0.469 \\
1.276 \\
1.421 \\
0.886 \\
0.770\end{array}$ & 0.964 \\
\hline 4 & $\begin{array}{l}0.3048 \\
0.3048 \\
0.3048 \\
0.3302 \\
0.3302\end{array}$ & $\begin{array}{l}0.469 \\
0.469 \\
0.469 \\
0.56 z \\
0.56 z\end{array}$ & $u .504$ & $\begin{array}{l}0.3310 \\
0.3810 \\
0.3810 \\
0.4572 \\
0.4572\end{array}$ & $\begin{array}{l}0.770 \\
0.770 \\
0.770 \\
1.138 \\
1.138\end{array}$ & 0.917 & $\begin{array}{l}0.4318 \\
0.4318 \\
.4572 \\
.457 c \\
0.4572\end{array}$ & $\begin{array}{l}1.008 \\
1.008 \\
1.138 \\
1.138 \\
1.138\end{array}$ & 1.086 \\
\hline 5 & $\begin{array}{l}0.2794 \\
0.2540 \\
0 . \ddot{2} 286 \\
0.2794 \\
0.1778\end{array}$ & $\begin{array}{l}0.384 \\
0.306 \\
0.233 \\
0.384 \\
0.116\end{array}$ & 0.285 & $\begin{array}{l}0.2540 \\
0.3048 \\
0.2286 \\
0.2540 \\
0.2794\end{array}$ & $\begin{array}{l}0.306 \\
0.469 \\
0.235 \\
0.306 \\
0.384\end{array}$ & 0.340 & $\begin{array}{l}.4318 \\
0.4318 \\
.4318 \\
.4064 \\
.4064\end{array}$ & $\begin{array}{l}1.008 \\
1.008 \\
1.008 \\
0.086 \\
0.886\end{array}$ & p.959 \\
\hline
\end{tabular}


Wear Volume Vs Load

\begin{tabular}{|c|c|c|c|c|c|c|c|c|c|}
\hline & \multicolumn{3}{|c|}{$2.5 \mathrm{kgs}$} & \multicolumn{3}{|c|}{$5 \mathrm{Kgs}$} & \multicolumn{3}{|c|}{$10 \mathrm{Kgs}$} \\
\hline $\begin{array}{l}\text { Test } \\
\text { No } \\
\end{array}$ & $\begin{array}{c}\text { Scrich } \\
\text { Width } \\
\mathrm{mm}\end{array}$ & $\begin{array}{l}\text { Wear } \\
\text { Volume } \\
\text { mm } 3 \\
\end{array}$ & $\begin{array}{l}\text { Wear } \\
\text { Volume } \\
\text { Average } \\
\end{array}$ & $\begin{array}{c}\text { Scratch } \\
\text { Width } \\
\text { inm }\end{array}$ & $\begin{array}{l}\text { Wear } \\
\text { Yolume } \\
\text { mm } 3\end{array}$ & $\begin{array}{l}\text { Wear } \\
\text { Volume } \\
\text { Avercge }\end{array}$ & \begin{tabular}{|c|} 
Scratch \\
width \\
$\mathbf{m m}$ \\
\end{tabular} & $\begin{array}{l}\text { Wear } \\
\text { Volume } \\
\text { mm } 3\end{array}$ & $\begin{array}{l}\text { Wert } \\
\text { Volume } \\
\text { Averuge }\end{array}$ \\
\hline 1 & $\mid \begin{array}{l}0.2794 \\
0.2794 \\
0.3048 \\
0.3302 \\
0.3556\end{array}$ & $\begin{array}{l}0.384 \\
0.384 \\
0.469 \\
0.562 \\
0.663\end{array}$ & 0.492 & $\begin{array}{l}0.3302 \\
0.4572 \\
0.3302 \\
0.2794 \\
0.3048\end{array}$ & $\begin{array}{l}0.562 \\
1.138 \\
0.562 \\
0.384 \\
0.469\end{array}$ & 0.623 & $\mid \begin{array}{l}0.3810 \\
0.3576 \\
0.4826 \\
0.5842 \\
0.4064\end{array}$ & $\begin{array}{l}0.770 \\
0.663 \\
1.276 \\
1.900 \\
0.806\end{array}$ & 1.099 \\
\hline 2 & $\mid \begin{array}{l}0.2286 \\
0.2236 \\
0.2286 \\
0.2286 \\
0.2540\end{array}$ & $\begin{array}{l}0.235 \\
0.235 \\
0.235 \\
0.235 \\
0.306\end{array}$ & $\begin{array}{c}0.249 \\
. .\end{array}$ & $\begin{array}{l}0.3550 \\
0.3556 \\
0.3302 \\
0.3502 \\
0.3048\end{array}$ & $\begin{array}{l}0.603 \\
0.603 \\
0.502 \\
0.502 \\
0.462\end{array}$ & 0.582 & $\left|\begin{array}{lll}0.3810 \\
0.4064 \\
0.3536 \\
0.3310 \\
0.4316\end{array}\right|$ & $\begin{array}{l}0.770 \\
0.386 \\
0.663 \\
0.770 \\
1.008\end{array}$ & 0.819 \\
\hline 3 & $\left\{\begin{array}{l}0.1524 \\
0.1778 \\
0.1778 \\
0.2032 \\
0.2540\end{array}\right.$ & $\begin{array}{l}0.068 \\
0.116 \\
0.116 \\
0.172 \\
0.306\end{array}$ & 0.155 & $\begin{array}{l}0.2794 \\
0.2794 \\
0.2540 \\
0.2540 \\
0.2540\end{array}$ & $\begin{array}{l}0.384 \\
0.384 \\
0.306 \\
0.306 \\
0.306\end{array}$ & 0.337 & $\begin{array}{l}0.355 \\
0.4318 \\
0.4064 \\
0.2794 \\
0.3556\end{array}$ & $\begin{array}{c}0.653 \\
1.008 \\
0.886 \\
0.304 \\
0.663\end{array}$ & 0.720 \\
\hline 4 & $\begin{array}{l}0.2540 \\
0.2540 \\
0.3048 \\
0.2794 \\
0.3048\end{array}$ & $\begin{array}{l}0.306 \\
0.306 \\
0.462 \\
0.384 \\
0.462\end{array}$ & 0.384 & $\begin{array}{l}0.3556 \\
0.3556 \\
0.4064 \\
0.3048 \\
0.3048\end{array}$ & $\begin{array}{l}0.663 \\
0.663 \\
0.386 \\
0.469 \\
0.469\end{array}$ & 0.630 & $\begin{array}{l}0.4826 \\
0.4326 \\
0.4826 \\
0.4572 \\
.4572\end{array}$ & $\begin{array}{l}1.276 \\
1.276 \\
1.276 \\
1.138 \\
1.138\end{array}$ & $1.2=0$ \\
\hline 5 & $\mid \begin{array}{l}0.203 z \\
0.2286 \\
0.2286 \\
0.2540 \\
0.2540\end{array}$ & $\begin{array}{l}0.172 \\
0.235 \\
0.235 \\
0.306 \\
0.306\end{array}$ & 0.249 & $\begin{array}{l}0.3048 \\
0.3556 \\
0.3556 \\
0.3556 \\
0.3556\end{array}$ & $\begin{array}{l}0.469 \\
0.663 \\
0.663 \\
0.663 \\
0.663\end{array}$ & 0.624 & $\begin{array}{l}0.3810 \\
.3810 \\
.4064 \\
0.4064 \\
0.4826\end{array}$ & $\begin{array}{l}0.770 \\
0.770 \\
0.886 \\
0.886 \\
1.276\end{array}$ & 0.917 \\
\hline
\end{tabular}


Wear Volume Vs Load

\begin{tabular}{|c|c|c|c|c|c|c|c|c|c|}
\hline & \multicolumn{3}{|c|}{$2.5 \mathrm{kgs}$} & \multicolumn{3}{|c|}{$5 \mathrm{Kgs}$} & \multicolumn{3}{|c|}{$10 \mathrm{Kgs}$} \\
\hline \begin{tabular}{|l} 
Test \\
No \\
\end{tabular} & \begin{tabular}{|c|}
$\begin{array}{c}\text { Scrutch } \\
\text { Width } \\
\mathrm{mm}\end{array}$ \\
\end{tabular} & \begin{tabular}{|l|} 
Wear \\
Volume \\
mm 3 \\
\end{tabular} & $\begin{array}{l}\text { Wear } \\
\text { Volume } \\
\text { Avergge }\end{array}$ & $\begin{array}{c}\text { Scratch } \\
\text { Width } \\
\text { mm }\end{array}$ & $\begin{array}{l}\text { Weor } \\
\text { Volume } \\
\text { mm } 3\end{array}$ & \begin{tabular}{|l|} 
Wear \\
Volume \\
Average \\
\end{tabular} & \begin{tabular}{|c|} 
Scratch \\
width \\
$\mathbf{m} \mathrm{m}$ \\
\end{tabular} & \begin{tabular}{|l|} 
Mear \\
Volume \\
mm 3 \\
\end{tabular} & $\begin{array}{l}\text { Wenr } \\
\text { Volume } \\
\text { Average }\end{array}$ \\
\hline 1 & $\begin{array}{l}0.5334 \\
0.5334 \\
0.5842 \\
0.3310 \\
0.3556\end{array}$ & $\begin{array}{l}1.573 \\
1.575 \\
1.900 \\
0.770 \\
0.663\end{array}$ & 1.296 & $\begin{array}{r}0.4064 \\
0.8636 \\
.6096 \\
0.6096 \\
.6096\end{array}$ & $\begin{array}{l}0.086 \\
4.230 \\
2.075 \\
2.075 \\
2.075\end{array}$ & 2.268 & $\mid \begin{array}{l}0.9398 \\
0.6604 \\
0.8890 \\
0.9144 \\
0.5334\end{array}$ & $\begin{array}{l}5.022 \\
2.446 \\
4.487 \\
4.750 \\
1.573\end{array}$ & 3.655 \\
\hline 2 & $\begin{array}{l}0.5334 \\
0.5334 \\
0 . .5334 \\
0.5334 \\
0.5334\end{array}$ & $\begin{array}{l}1.573 \\
1.573 \\
1.573 \\
1.573 \\
1 . .573\end{array}$ & $\begin{array}{c}1 . .573 \\
. .\end{array}$ & $\begin{array}{l}0.6858 \\
.6096 \\
.6096 \\
.6858 \\
.6096\end{array}$ & $\begin{array}{l}2.643 \\
2.075 \\
2.075 \\
2.643 \\
2.075\end{array}$ & 2.302 & $\mid \begin{array}{l}0.3556 \\
0.787 .4 \\
0.9652 \\
0.9906 \\
0.7620\end{array}$ & $\begin{array}{l}0.663 \\
3.437 \\
5.300 \\
5.587 \\
3.279\end{array}$ & 3.653 \\
\hline 3 & $\begin{array}{l}0.4826 \\
0.4826 \\
0.5080 \\
0.5080 \\
0.4826\end{array}$ & $\begin{array}{l}1.276 \\
1.276 \\
1.421 \\
1.421 \\
1.276\end{array}$ & 1.334 & $\begin{array}{l}0.5334 \\
.5588 \\
0.5842 \\
.4572 \\
0.4572\end{array}$ & $\begin{array}{l}1.573 \\
1.733 \\
1.900 \\
1.138 \\
1.138\end{array}$ & 1.496 & {$\left[\begin{array}{l}0.4064 \\
0.8636 \\
0.6096 \\
0.6096 \\
0.6096\end{array}\right.$} & $\begin{array}{l}0.886 \\
4.230 \\
2.075 \\
2.075 \\
2.075\end{array}$ & $\hat{c} .268$ \\
\hline 4 & $\begin{array}{l}0.5080 \\
0.5334 \\
0.5334 \\
0.4572 \\
0.4318\end{array}$ & $\begin{array}{l}1.421 \\
1.573 \\
1.573 \\
1.138 \\
1.008\end{array}$ & 1.342 & $\begin{array}{l}0.5334 \\
.6350 \\
.6604 \\
.5334 \\
.5334\end{array}$ & $\begin{array}{l}1.573 \\
2.272 \\
2.446 \\
1.573 \\
1.573\end{array}$ & 1.837 & $\begin{array}{l}0.5334 \\
0.7112 \\
1.0922 \\
0.6858 \\
0.5842\end{array}$ & $\begin{array}{l}1.573 \\
2.848 \\
6.805 \\
2.643 \\
1.900\end{array}$ & 3.154 \\
\hline 5 & $\begin{array}{l}0.5334 \\
0.5334 \\
0.5080 \\
0.7620 \\
0.3810\end{array}$ & $\begin{array}{l}1.573 \\
1.573 \\
1.421 \\
3.279 \\
0.770\end{array}$ & 1.723 & $\begin{array}{l}0.6858 \\
.7366 \\
.6604 \\
.6046 \\
0.6350\end{array}$ & $\begin{array}{l}2.643 \\
3.060 \\
2.446 \\
2.075 \\
z .<72\end{array}$ & 2.499 & $\begin{array}{l}0.8890 \\
0.3840 \\
0.8890 \\
0.8890 \\
0.8890\end{array}$ & $\begin{array}{l}4.487 \\
4.487 \\
4.487 \\
4.487 \\
4.487\end{array}$ & 4.467 \\
\hline
\end{tabular}


Wear Volume Vs Load

\begin{tabular}{|c|c|c|c|c|c|c|c|c|c|}
\hline & \multicolumn{3}{|c|}{$2.5 \mathrm{kgs}$} & \multicolumn{3}{|c|}{$5 \mathrm{Kgs}$} & \multicolumn{3}{|c|}{$10 \mathrm{Kgs}$} \\
\hline $\begin{array}{l}\text { Test } \\
\text { No } \\
\end{array}$ & \begin{tabular}{|c|}
$\begin{array}{c}\text { Scratch } \\
\text { Width } \\
\mathrm{mm}\end{array}$ \\
\end{tabular} & \begin{tabular}{|c|} 
Wear \\
Volume \\
m m 3 \\
\end{tabular} & \begin{tabular}{|l|} 
Wear \\
Volume \\
Averege
\end{tabular} & $\begin{array}{c}\text { Scratch } \\
\text { Width } \\
\text { mm } \\
\end{array}$ & \begin{tabular}{|l|} 
Wear \\
Yolume \\
mm 3 \\
\end{tabular} & $\begin{array}{l}\text { Wear } \\
\text { volume } \\
\text { Avercge }\end{array}$ & $\begin{array}{c}\text { Scroich } \\
\text { width } \\
\mathrm{m} \mathrm{m} \\
\end{array}$ & $\begin{array}{l}\text { Wear } \\
\text { Volume } \\
\text { mm } 3 \\
\end{array}$ & $\begin{array}{l}\text { Werir } \\
\text { Volume } \\
\text { Averuge }\end{array}$ \\
\hline 1 & $\begin{array}{l}0.2794 \\
0.2794 \\
0.3648 \\
0.2794 \\
0.2794\end{array}$ & $\begin{array}{l}0.384 \\
0.384 \\
0.469 \\
0.384 \\
0.384\end{array}$ & 0.401 & $\begin{array}{l}0.3048 \\
0.3556 \\
0.3556 \\
0.3556 \\
0.3556\end{array}$ & $\begin{array}{l}0.469 \\
0.663 \\
0.663 \\
0.663 \\
0.663\end{array}$ & 0.624 & $\begin{array}{l}0.3810 \\
0.4064 \\
0.4826 \\
0.5334 \\
0.3810\end{array}$ & $\begin{array}{l}0.770 \\
0.386 \\
1.276 \\
1.573 \\
0.770\end{array}$ & 1.055 \\
\hline 2 & $\begin{array}{l}0.4064 \\
0.4318 \\
0.4064 \\
0.3556 \\
0.3556\end{array}$ & $\begin{array}{l}0.886 \\
1.008 \\
0.886 \\
0.663 \\
0.663\end{array}$ & 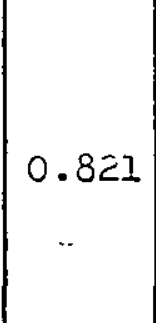 & $\mid \begin{array}{l}0.4826 \\
0.457 z \\
0.4825 \\
0.457 z \\
0.457 z\end{array}$ & $\begin{array}{l}1.276 \\
1.138 \\
1.276 \\
1.138 \\
1.138\end{array}$ & 1.193 & $\begin{array}{l}0.6096 \\
0.5082 \\
0.5842 \\
0.5588 \\
0.6350\end{array}$ & $\begin{array}{l}2.075 \\
1.421 \\
1.900 \\
1.133 \\
2.272\end{array}$ & \\
\hline 3 & $\begin{array}{l}0.4064 \\
0.3810 \\
0.3810 \\
0.3556 \\
0.3556\end{array}$ & $\begin{array}{l}0.886 \\
0.770 \\
0.770 \\
0.663 \\
0.663\end{array}$ & 0.750 & $\begin{array}{l}0.3810 \\
0.3810 \\
0.4572 \\
0.4572 \\
0.4572\end{array}$ & $\begin{array}{l}0.770 \\
0.770 \\
1.138 \\
1.138 \\
1.138\end{array}$ & 0.990 & $\begin{array}{l}0.4318 \\
0.4064 \\
.5583 \\
0.5538 \\
0.5588\end{array}$ & $\begin{array}{l}1.008 \\
0.886 \\
1.773 \\
1.773 \\
1.773\end{array}$ & 1.442 \\
\hline 4 & $\left\{\begin{array}{l}0.3810 \\
0.3810 \\
0.3556 \\
0.3048 \\
0.2794\end{array}\right.$ & $\begin{array}{l}0.770 \\
0.770 \\
0.603 \\
0.469 \\
0.384\end{array}$ & 0.611 & $\begin{array}{l}0.3310 \\
0.4318 \\
0.3556 \\
0.4572 \\
0.4064\end{array}$ & $\begin{array}{l}0.770 \\
1.008 \\
0.653 \\
1.138 \\
0.806\end{array}$ & 0.893 & $\begin{array}{l}0.5080 \\
.3010 \\
.4572 \\
0.5334 \\
.5388\end{array}$ & $\left\{\begin{array}{l}1.421 \\
0.770 \\
1.138 \\
1.573 \\
1.733\end{array}\right.$ & 1.327 \\
\hline 5 & $\begin{array}{l}0.3556 \\
0.2794 \\
0.3048 \\
0.2794 \\
0.3048\end{array}$ & $\begin{array}{l}0.603 \\
0.384 \\
0.469 \\
0.384 \\
0.469\end{array}$ & 0.473 & $\begin{array}{l}0.3010 \\
0.4064 \\
0.4064 \\
0.3810 \\
0.457 \bar{c}\end{array}$ & $\begin{array}{l}0.770 \\
0.836 \\
0.386 \\
0.770 \\
1.138\end{array}$ & 0.890 & $\begin{array}{l}0.4826 \\
.4826 \\
.4318 \\
.6858 \\
.6858\end{array}$ & $\begin{array}{l}1.276 \\
1.276 \\
1.008 \\
z .642 \\
z .643\end{array}$ & 11.769 \\
\hline
\end{tabular}


Wear Volume Vs Load

\begin{tabular}{|c|c|c|c|c|c|c|c|c|c|}
\hline & \multicolumn{3}{|c|}{$2.5 \mathrm{kgs}$} & \multicolumn{3}{|c|}{$5 \mathrm{kgs}$} & \multicolumn{3}{|c|}{$10 \mathrm{Kgs}$} \\
\hline $\begin{array}{l}\text { Test } \\
\text { No } \\
\end{array}$ & $\begin{array}{c}\text { Scraich } \\
\text { Width } \\
\mathrm{mm}\end{array}$ & \begin{tabular}{|c|} 
Wear \\
volume \\
$\mathrm{mm}^{2} 3$ \\
\end{tabular} & $\begin{array}{l}\text { Wear } \\
\text { Volume } \\
\text { Average }\end{array}$ & $\begin{array}{l}\text { Scratch } \\
\text { Width } \\
\text { mm } \\
\end{array}$ & $\begin{array}{c}\text { Wear } \\
\text { Volume } \\
\text { m m 3 }\end{array}$ & $\begin{array}{l}\text { Wear } \\
\text { volume } \\
\text { Avercge }\end{array}$ & $\begin{array}{c}\text { Scratch } \\
\text { Width } \\
\text { m m } \\
\end{array}$ & \begin{tabular}{|l|} 
Wear \\
Volume \\
mm 3
\end{tabular} & $\begin{array}{l}\text { Wear } \\
\text { Volume } \\
\text { Average }\end{array}$ \\
\hline 1 & $\left\{\begin{array}{l}0.2540 \\
0.2540 \\
0.4318 \\
0.2794 \\
0.2794\end{array}\right.$ & $\begin{array}{l}0.306 \\
u .306 \\
1.008 \\
0.384 \\
0.384\end{array}$ & 0.477 & $\begin{array}{l}0.3556 \\
0.5500 \\
0.4318 \\
0.3302 \\
0.4064\end{array}$ & $\begin{array}{l}0.003 \\
1.773 \\
1.008 \\
0.562 \\
0.006\end{array}$ & 0.973 & 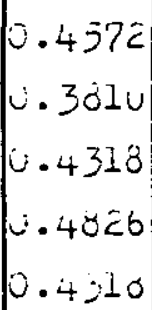 & $\begin{array}{l}1.130 \\
0.770 \\
1.008 \\
1.276 \\
1.008\end{array}$ & \pm .040 \\
\hline 2 & $\begin{array}{l}0.2540 \\
0.2540 \\
0.2540 \\
0.2236 \\
0.2754\end{array}$ & $\begin{array}{l}i .306 \\
0.306 \\
0.306 \\
0.235 \\
0.304\end{array}$ & $\begin{array}{l}0.307 \\
. .\end{array}$ & $\begin{array}{l}0.3048 \\
0.3548 \\
0.2794 \\
0.277 y 4 \\
0.3048\end{array}$ & $\left\{\begin{array}{l}0.469 \\
u .56 z \\
u .504 \\
0.504 \\
u .46 y\end{array}\right.$ & $u .453$ & 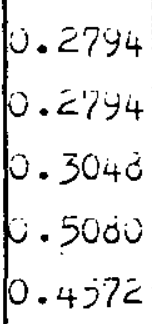 & $\begin{array}{l}0.384 \\
0.384 \\
0.409 \\
1.461 \\
1.138\end{array}$ & p.759 \\
\hline 3 & $\left\{\begin{array}{l}0.1524 \\
0.203 z \\
0.203 \dot{c} \\
0.203 c \\
0.2540\end{array}\right.$ & $\begin{array}{l}0.068 \\
0.172 \\
0.172 \\
0.172 \\
0.306\end{array}$ & $\cup .178$ & $\begin{array}{l}0.3306 \\
0.4064 \\
0.2286 \\
0.2<36 \\
0.2<80\end{array}$ & $\begin{array}{l}0.563 \\
0.386 \\
0.235 \\
0.235 \\
0.235\end{array}$ & 0.430 & $\begin{array}{l}0.4064 \\
.4064 \\
.4004 \\
.330 c \\
.3556\end{array}$ & $\begin{array}{l}0.086 \\
0.806 \\
0.806 \\
0.562 \\
0.663\end{array}$ & p.7\%6 \\
\hline 4 & $\begin{array}{l}0.2032 \\
0.203 z \\
0 . \angle 03 c \\
0.203 z \\
0 . \angle 03 c\end{array}$ & $\begin{array}{l}0.17 z \\
0.17 z \\
0.17 z \\
0.17 z \\
0.17 z\end{array}$ & $0.17 c$ & $\left\{\begin{array}{l}0.3048 \\
0.2194 \\
0.27 y 4 \\
u .2206 \\
0.2206\end{array}\right.$ & $\begin{array}{l}0.469 \\
0.384 \\
0.384 \\
0.255 \\
0.255\end{array}$ & 0.341 & $\left\{\begin{array}{l}.3500 \\
.27 y 4 \\
.3048 \\
.3048 \\
.3302\end{array}\right.$ & $\left\{\begin{array}{l}0.663 \\
0.304 \\
0.469 \\
0.56 \ddot{6} \\
0.469\end{array}\right.$ & p.5ug \\
\hline 5 & $\left\{\begin{array}{l}0 . \angle 03 c \\
0.203 c \\
0.2286 \\
0.1718 \\
0.1770\end{array}\right.$ & $\begin{array}{l}0.172 \\
0.17 z \\
0.230 \\
0.116 \\
0.110\end{array}$ & $u . \ddot{1} 6 \ddot{c}$ & $\begin{array}{l}u .2540 \\
u .2540 \\
0.2794 \\
0.2794 \\
0.4318\end{array}$ & $\begin{array}{l}0.306 \\
0.306 \\
0.384 \\
0.304 \\
1.008\end{array}$ & 0.477 & $\left\{\begin{array}{l}.3010 \\
.4004 \\
.3556 \\
.3302 \\
.3010\end{array}\right.$ & $\begin{array}{l}0.170 \\
0.006 \\
0.003 \\
0.562 \\
0.770\end{array}$ & 0.730 \\
\hline
\end{tabular}


Wear Volume Vs Load

\begin{tabular}{|c|c|c|c|c|c|c|c|c|c|}
\hline & \multicolumn{3}{|c|}{$2.5 \mathrm{kgs}$} & \multicolumn{3}{|c|}{$5 \mathrm{kgs}$} & \multicolumn{3}{|c|}{$10 \mathrm{kgs}$} \\
\hline $\begin{array}{l}\text { Test } \\
\text { No }\end{array}$ & $\mid \begin{array}{c}\text { Scratch } \\
\text { Width } \\
\mathrm{mm}\end{array}$ & $\begin{array}{l}\text { Wear } \\
\text { volumin } \\
\text { mm } 3\end{array}$ & $\begin{array}{l}\text { Wear } \\
\text { Volume } \\
\text { Avergge }\end{array}$ & $\begin{array}{l}\text { Scratch } \\
\text { Width } \\
\text { mm }\end{array}$ & $\begin{array}{l}\text { Wear } \\
\text { Volume } \\
\text { mm } 3\end{array}$ & $\begin{array}{l}\text { Yyear } \\
\text { vilume } \\
\text { Avercge }\end{array}$ & $\begin{array}{c}\text { Scratich } \\
\text { width } \\
\mathrm{m} \mathrm{m}\end{array}$ & $\begin{array}{l}\text { Year } \\
\text { Volume } \\
\text { mm } 3 \\
\end{array}$ & $\begin{array}{l}\text { iveri } \\
\text { Volume } \\
\text { Averige }\end{array}$ \\
\hline 1 & $\left\{\begin{array}{l}0.2540 \\
.2540 \\
.2200 \\
.2036 \\
.<286\end{array}\right.$ & $\begin{array}{l}0.306 \\
0.306 \\
u .235 \\
0.172 \\
0.255\end{array}$ & 2.251 & $\begin{array}{l}0 . \dot{2} 286 \\
0.2286 \\
u .2286 \\
u .2540 \\
u .<540\end{array}$ & $\begin{array}{l}0.235 \\
0.235 \\
0.235 \\
0.306 \\
0.306\end{array}$ & 0.263 & $\begin{array}{l}\text { i. } 3536 \\
\text { c. } 27 y 4 \\
\text { ic } 2794 \\
\text { i. } 2794 \\
0.3448\end{array}$ & $\begin{array}{l}0.063 \\
0.384 \\
u .384 \\
u .384 \\
0.46 y\end{array}$ & 0.456 \\
\hline 2 & $\begin{array}{l}0.1778 \\
0.1778 \\
.1778 \\
.1778 \\
.1778\end{array}$ & $\begin{array}{l}0.116 \\
0.116 \\
0.116 \\
0.116 \\
0.116\end{array}$ & $\begin{array}{c}0.116 \\
. .\end{array}$ & $\begin{array}{l}0.2540 \\
0.2286 \\
0.2280 \\
0.2032 \\
0.1778\end{array}$ & $\begin{array}{l}0.306 \\
0.235 \\
0.235 \\
0.17 z \\
0.116\end{array}$ & 0.213 & $\begin{array}{l}0 . z 7 y 4 \\
0.3040 \\
0.2794 \\
0.3030 \\
0.2794\end{array}$ & $\begin{array}{l}0.304 \\
0.469 \\
0.38 . t \\
0.46 y \\
0.384\end{array}$ & 0.418 \\
\hline 3 & $\left\{\begin{array}{l}0.2032 \\
0.2236 \\
0.203 \ddot{c} \\
0.1524 \\
0.1770\end{array}\right.$ & $\begin{array}{l}0.172 \\
0.235 \\
0.172 \\
0.668 \\
0.116\end{array}$ & $0.15 z$ & $\begin{array}{l}0.2032 \\
0.2286 \\
0.3048 \\
0.2032 \\
0.2032\end{array}$ & $\begin{array}{l}0.17 \bar{z} \\
0.235 \\
0.46 y \\
0.172 \\
0.172\end{array}$ & 0.244 & $\begin{array}{l}u .330 \\
0.2286 \\
.3302 \\
.2236 \\
.3302\end{array}$ & $\begin{array}{l}0.562 \\
0.235 \\
0.562 \\
0.235 \\
0.562\end{array}$ & 0.431 \\
\hline 4 & $\left\{\begin{array}{l}0.203 z \\
0.203 c \\
0.203 c \\
0.2286 \\
0.2200\end{array}\right.$ & $\left\{\begin{array}{l}0.17 z \\
0.17 z \\
0.17 z \\
0.23 j \\
0.235\end{array}\right.$ & 0.197 & $\begin{array}{l}u .2032 \\
0 . z u 3 z \\
0.2286 \\
0.2286 \\
u .2<80\end{array}$ & $\begin{array}{l}0.172 \\
0.172 \\
0.235 \\
0.235 \\
0.235\end{array}$ & 0.209 & $\left\{\begin{array}{l}.2540 \\
.2540 \\
.2794 \\
.27 y 4 \\
.4310\end{array}\right.$ & $\begin{array}{l}0.306 \\
0.306 \\
0.384 \\
0.384 \\
1.008\end{array}$ & p.477 \\
\hline 5 & $\begin{array}{l}.203 c \\
.203 c \\
.203 z \\
.2032 \\
.203 c\end{array}$ & $\begin{array}{l}0.172 \\
0.172 \\
0.172 \\
0.172 \\
0.172\end{array}$ & 0.172 & $\begin{array}{l}0.2540 \\
0.2540 \\
0.2286 \\
0.2032 \\
0.3040\end{array}$ & $\begin{array}{l}0.306 \\
0.506 \\
0.235 \\
0.172 \\
0.469\end{array}$ & 0.297 & $\begin{array}{l}.2794 \\
.2794 \\
.2794 \\
.2794 \\
.2794\end{array}$ & $\begin{array}{l}0.384 \\
0.384 \\
0.384 \\
0.384 \\
0.384\end{array}$ & $p \cdot 384$ \\
\hline
\end{tabular}


Wear Volume Vs Load

\begin{tabular}{|c|c|c|c|c|c|c|c|c|c|}
\hline & \multicolumn{3}{|c|}{$2.5 \mathrm{kgs}$} & \multicolumn{3}{|c|}{$5 \mathrm{Kgs}$} & \multicolumn{3}{|c|}{$10 \mathrm{Kgs}$} \\
\hline $\begin{array}{l}\text { Test } \\
\text { No } \\
\end{array}$ & \begin{tabular}{|c|}
$\begin{array}{c}\text { Scratch } \\
\text { width } \\
\text { m m }\end{array}$ \\
\end{tabular} & $\begin{array}{l}\text { Wear } \\
\text { volume } \\
\text { mm } 3 \\
\end{array}$ & \begin{tabular}{|l|} 
Wear \\
Volume \\
Avergge \\
\end{tabular} & \begin{tabular}{|c|} 
Scratch \\
Width \\
mm \\
\end{tabular} & \begin{tabular}{|l|} 
Wear \\
Volume \\
m m 3 \\
\end{tabular} & $\begin{array}{l}\text { Wear } \\
\text { Volume } \\
\text { Avercge }\end{array}$ & $\begin{array}{c}\text { Scratch } \\
\text { width } \\
\mathrm{m} m\end{array}$ & $\begin{array}{l}\text { Wear } \\
\text { Volume } \\
\text { mm? } \\
\end{array}$ & $\begin{array}{l}\text { Wear } \\
\text { Volume } \\
\text { Average } \\
\end{array}$ \\
\hline 1 & $\begin{array}{l}0.2540 \\
0.2540 \\
0.4518 \\
0.27 y 4 \\
0.27 y 4\end{array}$ & $\begin{array}{l}0.306 \\
0.306 \\
1.008 \\
0.384 \\
0.384\end{array}$ & 0.477 & $\begin{array}{l}.3556 \\
.5508 \\
0.4318 \\
0.3308 \\
0.4064\end{array}$ & $\begin{array}{l}0.603 \\
1.773 \\
1.008 \\
0.562 \\
0.306\end{array}$ & 0.978 & $\mid \begin{array}{l}0.4572 \\
0.3010 \\
0.4318 \\
0.4826 \\
0.4318\end{array}$ & $\begin{array}{l}1.138 \\
0.170 \\
1.008 \\
1.276 \\
1.008\end{array}$ & 1.040 \\
\hline 2 & $\begin{array}{l}0.3556 \\
0.27 y 4 \\
0.3048 \\
0.330 c \\
0.3048\end{array}$ & $\begin{array}{l}0.603 \\
0.384 \\
0.469 \\
0.562 \\
0.469\end{array}$ & $\begin{array}{c}0.50 y \\
.\end{array}$ & $\begin{array}{l}0.4064 \\
0.4064 \\
0.3502 \\
0.3556 \\
0.4064\end{array}$ & $\begin{array}{l}0.886 \\
0.806 \\
0.562 \\
0.653 \\
0.806\end{array}$ & 0.776 & $\mid \begin{array}{l}0.3536 \\
0.4318 \\
0.5538 \\
0.3502 \\
0 .+064\end{array}$ & $\begin{array}{l}0.603 \\
1.008 \\
1.773 \\
0.562 \\
0.306\end{array}$ & 0.978 \\
\hline 3 & $\begin{array}{l}0.2286 \\
0.2236 \\
0.2794 \\
0.2794 \\
0.2540\end{array}$ & $\begin{array}{l}0.235 \\
0.235 \\
0.0384 \\
0.384 \\
0.306\end{array}$ & 0.308 & $\begin{array}{l}0.3048 \\
0.4572 \\
0.3302 \\
0.3302 \\
0.27 y 4\end{array}$ & $\begin{array}{l}0.469 \\
1.138 \\
0.562 \\
0.562 \\
0.334\end{array}$ & 0.623 & $\begin{array}{l}0.3810 \\
0.35 j 6 \\
0.4064 \\
0.4826 \\
0.5842\end{array}$ & $\begin{array}{l}0.770 \\
0.663 \\
0.806 \\
1.276 \\
1.900\end{array}$ & 1.099 \\
\hline 4 & $\begin{array}{l}0.2540 \\
0.2540 \\
0.2540 \\
0.2236 \\
0.2540\end{array}$ & $\begin{array}{l}0.306 \\
0.306 \\
0.306 \\
0.235 \\
0.306\end{array}$ & 0.291 & $\begin{array}{l}0.2540 \\
0.2794 \\
0.3040 \\
0.3048 \\
0.3040\end{array}$ & $\begin{array}{l}0.306 \\
0.304 \\
0.469 \\
0.469 \\
0.409\end{array}$ & 0.419 & $\begin{array}{l}0.60 y 6 \\
.4572 \\
.3556 \\
.3556 \\
.3550\end{array}$ & $\begin{array}{l}2.075 \\
1.130 \\
0.603 \\
0.663 \\
0.663\end{array}$ & 1.040 \\
\hline 5 & {$\left[\begin{array}{l}0.3536 \\
0.3302 \\
0.3040 \\
0.3048 \\
0.3302\end{array}\right.$} & $\begin{array}{l}0.663 \\
0.562 \\
0.469 \\
0.469 \\
0.502\end{array}$ & 0.545 & $\mid \begin{array}{l}0.3556 \\
0.4318 \\
0.4318 \\
0.4572 \\
0.3810\end{array}$ & $\begin{array}{l}0.663 \\
1.008 \\
1.008 \\
1.138 \\
0.770\end{array}$ & 0.917 & $\begin{array}{l}p .5000 \\
.4064 \\
.5334 \\
.5334 \\
.4318\end{array}$ & $\begin{array}{l}1.421 \\
0.086 \\
1.573 \\
1.573 \\
1.008\end{array}$ & 1.292 \\
\hline
\end{tabular}


Wear Volume Vs Load

\begin{tabular}{|c|c|c|c|c|c|c|c|c|c|}
\hline & \multicolumn{3}{|c|}{$2.5 \mathrm{kgs}$} & \multicolumn{3}{|c|}{$5 \mathrm{Kgs}$} & \multicolumn{3}{|c|}{$10 \mathrm{Kgs}$} \\
\hline \begin{tabular}{|l|} 
Test \\
No
\end{tabular} & $\begin{array}{c}\text { Scroich } \\
\text { Width } \\
\mathrm{mm}\end{array}$ & $\begin{array}{l}\text { Wear } \\
\text { Volume } \\
\text { mm3 } \\
\end{array}$ & $\begin{array}{l}\text { Woar } \\
\text { Volume } \\
\text { Average } \\
\end{array}$ & $\begin{array}{l}\text { Scratch } \\
\text { Widith } \\
\text { mm }\end{array}$ & $\begin{array}{l}\text { Wear } \\
\text { Yolume } \\
\text { mm } 3 \\
\end{array}$ & $\begin{array}{l}\text { Weor } \\
\text { Vulume } \\
\text { Avercoge }\end{array}$ & $\begin{array}{c}\text { Scrotch } \\
\text { width } \\
\mathrm{m} \mathrm{m} \\
\end{array}$ & $\begin{array}{l}\text { Wear } \\
\text { Volume } \\
\text { mm } 3 \\
\end{array}$ & $\begin{array}{l}\text { Werr } \\
\text { Volume } \\
\text { Averuge }\end{array}$ \\
\hline 1 & $\left\{\begin{array}{l}0.2540 \\
0.2540 \\
0.2794 \\
0.27 y 4 \\
0.2540\end{array}\right.$ & $\begin{array}{l}0.306 \\
0.306 \\
0.384 \\
0.384 \\
0.306\end{array}$ & 0.137 & $\begin{array}{l}0.3300 \\
0.3550 \\
0.330 \\
0.3040 \\
0.304\end{array}$ & $\begin{array}{l}0.56 z \\
0.663 \\
0.562 \\
0.469 \\
0.46 y\end{array}$ & 0.545 & $\mid \begin{array}{l}0.3556 \\
0.3556 \\
0.4516 \\
0.4316 \\
0.4064\end{array}$ & $\begin{array}{l}0.663 \\
0.663 \\
1.008 \\
1.008 \\
0.006\end{array}$ & 0.845 \\
\hline 2 & $\mid \begin{array}{l}0.2286 \\
0.2036 \\
0.2794 \\
0.2794 \\
0.3040\end{array}$ & $\begin{array}{l}0.235 \\
0.172 \\
0.304 \\
0.384 \\
0.469\end{array}$ & $\begin{array}{c}0.329 \\
.\end{array}$ & $\begin{array}{l}0.3040 \\
0.3814 \\
0.3810 \\
0.330 \\
0.3810\end{array}$ & $\begin{array}{l}0.469 \\
0.770 \\
0.770 \\
0.502 \\
0.770\end{array}$ & 0.600 & $\mid \begin{array}{l}0.5580 \\
0.5080 \\
0.4510 \\
0.5588 \\
0.4826\end{array}$ & $\begin{array}{l}1.733 \\
1.421 \\
1.000 \\
1.733 \\
1.276\end{array}$ & 1.434 \\
\hline 3 & $\begin{array}{l}0.2286 \\
0.2540 \\
0.2286 \\
0.2540 \\
0.2286\end{array}$ & $\begin{array}{l}0.335 \\
0.306 \\
0.235 \\
0.306 \\
0.235\end{array}$ & 0.263 & $\begin{array}{l}0.2794 \\
0.2794 \\
0.3048 \\
0.2540 \\
0.3040\end{array}$ & $\begin{array}{l}0.384 \\
0.384 \\
0.469 \\
0.306 \\
0.469\end{array}$ & 0.402 & $\begin{array}{l}0.5080 \\
0.4572 \\
0.4572 \\
0.4064 \\
0.3556\end{array}$ & $\begin{array}{l}1.421 \\
1.138 \\
1.138 \\
0.886 \\
0.663\end{array}$ & 1.043 \\
\hline 4 & $\begin{array}{l}0.2286 \\
0.2286 \\
0.27 y 4 \\
0.27 y 4 \\
0.2540\end{array}$ & $\begin{array}{l}0 .<35 \\
0.2355 \\
0.384 \\
0.304 \\
0.306\end{array}$ & 0.308 & $\begin{array}{l}0.3810 \\
0.3040 \\
0.2794 \\
0.3810 \\
0.3556\end{array}$ & $\begin{array}{l}0.770 \\
0.46 y \\
0.384 \\
0.770 \\
0.663\end{array}$ & 0.611 & $\begin{array}{l}0.4572 \\
0.3010 \\
0.5334 \\
0.3040 \\
0.3302\end{array}$ & $\begin{array}{l}1.138 \\
0.170 \\
1.573 \\
0.469 \\
0.562\end{array}$ & $10.70 z$ \\
\hline 5 & $\mid \begin{array}{l}0.2540 \\
0.2794 \\
0.2540 \\
0.2794 \\
0.27 y 4\end{array}$ & $\begin{array}{l}0.306 \\
0.384 \\
0.306 \\
0.384 \\
0.384\end{array}$ & $0.35 c$ & $\begin{array}{l}0.3810 \\
0.3810 \\
0.3556 \\
0.3556 \\
0.4064\end{array}$ & $\begin{array}{l}0.770 \\
0.770 \\
0.663 \\
0.663 \\
0.356\end{array}$ & 0.750 & $\begin{array}{l}0.5080 \\
0.5508 \\
0.5334 \\
0.4572 \\
0.3810\end{array}$ & $\begin{array}{l}1.451 \\
1.733 \\
1.573 \\
1.138 \\
0.770\end{array}$ & $1 \cdot 3<7$ \\
\hline
\end{tabular}


Table 25

Wear Volume Vs Load

\begin{tabular}{|c|c|c|c|c|c|c|c|c|c|}
\hline & \multicolumn{3}{|c|}{$2.5 \mathrm{kgs}$} & \multicolumn{3}{|c|}{$5 \mathrm{kgs}$} & \multicolumn{3}{|c|}{$10 \mathrm{Kgs}$} \\
\hline $\begin{array}{l}\text { Test } \\
\text { No }\end{array}$ & $\begin{array}{c}\text { Scratch } \\
\text { Width } \\
\mathrm{mm}\end{array}$ & \begin{tabular}{|c|} 
Wear \\
Volume \\
mm 3 \\
\end{tabular} & \begin{tabular}{|l|} 
Wear \\
Volume \\
Avergge
\end{tabular} & $\begin{array}{c}\text { Scratch } \\
\text { Width } \\
\mathrm{mm}\end{array}$ & \begin{tabular}{|l|} 
Wear \\
Volume \\
mm 3 \\
\end{tabular} & $\begin{array}{l}\text { Wear } \\
\text { Volume } \\
\text { Averoge }\end{array}$ & $\begin{array}{c}\text { Scratch } \\
\text { width } \\
\mathrm{mm}\end{array}$ & $\begin{array}{l}\text { Wear } \\
\text { Volume } \\
\text { mm 3 } \\
\end{array}$ & $\begin{array}{l}\text { Wear } \\
\text { Volume } \\
\text { Average }\end{array}$ \\
\hline 1 & $\left|\begin{array}{l}0.3556 \\
0.3502 \\
0.3810 \\
0.3302 \\
0.3556\end{array}\right|$ & $\begin{array}{l}0.663 \\
0.562 \\
0.770 \\
0.562 \\
0.663\end{array}$ & 0.644 & $\left|\begin{array}{c}0.3810 \\
0.3810 \\
0.4064 \\
0.4064 \\
0.4310\end{array}\right|$ & $\begin{array}{l}0.770 \\
0.770 \\
0.886 \\
0.886 \\
1.008\end{array}$ & 0.364 & $\begin{array}{l}0.6350 \\
0.9144 \\
0.5334 \\
0.4826 \\
0.4326\end{array}$ & $\begin{array}{l}2.272 \\
4.750 \\
1.573 \\
1.276 \\
1.276\end{array}$ & 2.229 \\
\hline 2 & $\mid \begin{array}{l}0.3556 \\
0.3302 \\
0.3556 \\
0.3556 \\
0.3310\end{array}$ & $\begin{array}{l}0.663 \\
0.562 \\
0.603 \\
0.663 \\
0.770\end{array}$ & $\begin{array}{c}0.664 \\
. .\end{array}$ & $\mid \begin{array}{l}0.5080 \\
0.4318 \\
0.4064 \\
0.4004 \\
0.457 \mathrm{c}\end{array}$ & $\begin{array}{l}1.421 \\
1.008 \\
0.886 \\
0.806 \\
1.138\end{array}$ & 1.067 & $\begin{array}{l}0.3040 \\
0.3810 \\
0.4872 \\
0.4826 \\
0.6350\end{array}$ & $\begin{array}{l}0.469 \\
0.770 \\
1.138 \\
1.276 \\
2.272\end{array}$ & 1.135 \\
\hline 3 & $\mid \begin{array}{l}0.3556 \\
0.3556 \\
0.3302 \\
0.3556 \\
0.3010\end{array}$ & $\begin{array}{l}0.663 \\
0.663 \\
0.562 \\
0.663 \\
0.770\end{array}$ & 0.664 & $\begin{array}{l}0.3302 \\
0.3810 \\
0.3302 \\
0.3810 \\
0.4310\end{array}$ & $\begin{array}{l}0.562 \\
0.770 \\
0.562 \\
0.770 \\
1.008\end{array}$ & 0.734 & $\begin{array}{l}0.5080 \\
0.4572 \\
0.4318 \\
0.4826 \\
0.6350\end{array}$ & $\begin{array}{l}1.421 \\
1.138 \\
1.008 \\
1.276 \\
2.272\end{array}$ & 1.423 \\
\hline 4 & $\mid \begin{array}{l}0.27 y 4 \\
0.330 z \\
0.330 z \\
0.3048 \\
0.457 z\end{array}$ & $\begin{array}{l}0.384 \\
0.562 \\
0.562 \\
0.469 \\
1.138\end{array}$ & 0.623 & $\left|\begin{array}{c}0.4064 \\
0.4004 \\
0.3010 \\
0.3819 \\
0.4064\end{array}\right|$ & $\begin{array}{l}0.806 \\
0.386 \\
0.770 \\
0.770 \\
0.306\end{array}$ & 0.839 & $\left\{\begin{array}{l}0.5842 \\
0.8128 \\
0.5080 \\
0.4572 \\
0.4572\end{array}\right.$ & $\begin{array}{l}1.900 \\
3.740 \\
1.421 \\
1.138 \\
1.138\end{array}$ & 1.667 \\
\hline 5 & $\mid \begin{array}{c}0.301 \\
0.3810 \\
0.4318 \\
0.4004 \\
0.4064\end{array}$ & $\begin{array}{l}0.77 \\
0.770 \\
1.008 \\
0.836 \\
0.886\end{array}$ & 0.864 & $\begin{array}{l}0.457 \\
u .457 \\
u .457 \\
0.5500 \\
0.5500\end{array}$ & $\begin{array}{l}1.130 \\
1.138 \\
1.138 \\
1.733 \\
1.735\end{array}$ & 1.376 & $\begin{array}{l}0.5 .380 \\
0.4318 \\
0.4572 \\
0.4572 \\
0.4572\end{array}$ & $\begin{array}{l}1.421 \\
1.008 \\
1.133 \\
1.138 \\
1.138\end{array}$ & 1.086 \\
\hline
\end{tabular}


Wear Volume Vs Load

\begin{tabular}{|c|c|c|c|c|c|c|c|c|c|}
\hline & \multicolumn{3}{|c|}{$2.5 \mathrm{kgs}$} & \multicolumn{3}{|c|}{$5 \mathrm{Kgs}$} & \multicolumn{3}{|c|}{$10 \mathrm{Kgs}$} \\
\hline $\begin{array}{l}\text { Test } \\
\text { No }\end{array}$ & $\begin{array}{c}\text { Scratch } \\
\text { Width } \\
\text { min }\end{array}$ & $\begin{array}{l}\text { Wear } \\
\text { Volume } \\
\mathrm{mm} \text { ? }\end{array}$ & $\begin{array}{l}\text { Wear } \\
\text { Volume } \\
\text { Average }\end{array}$ & $\begin{array}{l}\text { Scrotch } \\
\text { Width } \\
\text { inm }\end{array}$ & \begin{tabular}{|l|} 
Wear \\
yolume \\
mm 3 \\
\end{tabular} & $\begin{array}{l}\text { Wear } \\
\text { vilume } \\
\text { Avercge }\end{array}$ & \begin{tabular}{c|} 
Scratich \\
wijdth \\
$\mathrm{mm}$ \\
\end{tabular} & \begin{tabular}{|l} 
Vear \\
Volume \\
mm 3 \\
\end{tabular} & $\begin{array}{l}\text { Werr } \\
\text { Volume } \\
\text { Averinge }\end{array}$ \\
\hline 1 & $\begin{array}{l}0.3556 \\
0.3302 \\
0.3310 \\
0.3302 \\
0.3556\end{array}$ & $\begin{array}{l}0.663 \\
0.562 \\
0.770 \\
0.562 \\
0.663\end{array}$ & 3.644 & $\begin{array}{l}0.3010 \\
0.3810 \\
0.4004 \\
0.4064 \\
0.4318\end{array}$ & $\begin{array}{l}0.770 \\
0.770 \\
0.386 \\
0.886 \\
1.008\end{array}$ & 0.864 & $\begin{array}{l}0.6350 \\
0.5334 \\
0.5334 \\
0.4826 \\
0.4826\end{array}$ & $\begin{array}{l}2.272 \\
1.573 \\
1.573 \\
1.276 \\
1.276\end{array}$ & 1.594 \\
\hline 2 & $\begin{array}{l}0.4064 \\
0.3810 \\
0.3556 \\
0.3810 \\
0.3048\end{array}$ & $\begin{array}{l}0.886 \\
0.770 \\
0.603 \\
0.770 \\
0.469\end{array}$ & $\begin{array}{c}0.711 \\
.\end{array}$ & $\begin{array}{l}0.4312 \\
0.3810 \\
0.4572 \\
0.3302 \\
0.3048\end{array}$ & $\begin{array}{l}1.008 \\
0.770 \\
1.138 \\
0.502 \\
0.469\end{array}$ & 10.789 & $\mid \begin{array}{l}0.4826 \\
0.5080 \\
0.4572 \\
0.3010 \\
0.4313\end{array}$ & $\begin{array}{l}1.276 \\
1.421 \\
1.158 \\
0.770 \\
1.008\end{array}$ & 1.122 \\
\hline 3 & $\begin{array}{l}0.3502 \\
0.3556 \\
0.3302 \\
0.3048 \\
0.3048\end{array}$ & $\begin{array}{l}0.562 \\
0.663 \\
0.562 \\
0.469 \\
0.469\end{array}$ & 0.545 & $\begin{array}{l}0.3810 \\
0.4572 \\
0.3556 \\
0.3810 \\
0.3810\end{array}$ & $\begin{array}{l}0.770 \\
1.138 \\
0.663 \\
0.770 \\
0.770\end{array}$ & 0.882 & $\begin{array}{l}0.4318 \\
0.4826 \\
0.4572 \\
0.5080 \\
0.3810\end{array}$ & $\begin{array}{l}1.008 \\
1.276 \\
1.138 \\
1.421 \\
0.770\end{array}$ & 1.122 \\
\hline 4 & $\mid \begin{array}{l}0.3556 \\
0.3048 \\
0.3556 \\
0.3302 \\
0.3302\end{array}$ & $\begin{array}{l}0.603 \\
0.465 \\
0.663 \\
0.562 \\
0.562\end{array}$ & 0.502 & $\begin{array}{l}0.3556 \\
0.3040 \\
0.4826 \\
0.3556 \\
0.3502\end{array}$ & $\begin{array}{l}0.663 \\
0.469 \\
1.276 \\
0.663 \\
0.562\end{array}$ & 0.726 & $\begin{array}{l}0.6350 \\
0.3010 \\
0.7366 \\
0.4326 \\
0.5334\end{array}$ & $\begin{array}{l}2.272 \\
0.770 \\
3.060 \\
1.276 \\
1.573\end{array}$ & 1.790 \\
\hline 5 & $\begin{array}{l}0.3556 \\
0.3536 \\
0.3043 \\
0.3048 \\
0.3043\end{array}$ & $\begin{array}{l}0.063 \\
0.663 \\
0.469 \\
0.469 \\
0.469\end{array}$ & 0.546 & $\begin{array}{l}0.3310 \\
0.3010 \\
0.4064 \\
0.4064 \\
0.4064\end{array}$ & $\begin{array}{l}0.770 \\
0.770 \\
0.886 \\
0.886 \\
0.886\end{array}$ & 0.039 & $\begin{array}{l}0.5842 \\
0.8128 \\
0.5080 \\
0.4572 \\
0.4572\end{array}$ & $\begin{array}{l}1.900 \\
3.740 \\
1.421 \\
1.138 \\
1.138\end{array}$ & 1.667 \\
\hline
\end{tabular}


Table 27

Wear Volume Vs Load

\begin{tabular}{|c|c|c|c|c|c|c|c|c|c|}
\hline & \multicolumn{3}{|c|}{$2.5 \mathrm{kgs}$} & \multicolumn{3}{|c|}{$5 \mathrm{kgs}$} & \multicolumn{3}{|c|}{$10 \mathrm{kgs}$} \\
\hline $\begin{array}{l}\text { Test } \\
\text { No }\end{array}$ & $\begin{array}{c}\text { Scrutich } \\
\text { Width } \\
\mathrm{mm}\end{array}$ & $\begin{array}{l}\text { Wear } \\
\text { Volume } \\
\text { mm } 3\end{array}$ & $\begin{array}{l}\text { Wear } \\
\text { Volume } \\
\text { Avergge }\end{array}$ & \begin{tabular}{|c|} 
Scratich \\
Widith \\
$\mathrm{mm}$
\end{tabular} & $\begin{array}{l}\text { Wear } \\
\text { Volume } \\
\text { mm } 3 \\
\end{array}$ & $\begin{array}{l}\text { Wear } \\
\text { Volume } \\
\text { Average }\end{array}$ & \begin{tabular}{|c|} 
Scratch \\
wid th \\
$\mathrm{mm}$ \\
\end{tabular} & \begin{tabular}{|l|} 
Wear \\
Volume \\
mm 3 \\
\end{tabular} & $\begin{array}{l}\text { Werr } \\
\text { Volume } \\
\text { Average }\end{array}$ \\
\hline 1 & $\mid \begin{array}{l}0.4064 \\
0.4064 \\
0.4572 \\
0.5508 \\
0.5000\end{array}$ & $\begin{array}{l}0.836 \\
0.086 \\
1.138 \\
1.733 \\
1.421\end{array}$ & 1.213 & $\mid \begin{array}{l}0.7366 \\
0.5588 \\
0.7366 \\
0.7366 \\
0.5354\end{array}$ & $\begin{array}{l}3.060 \\
1.733 \\
3.060 \\
3.060 \\
1.573\end{array}$ & $\ddot{2} .497$ & $\mid \begin{array}{l}0.0636 \\
0.8128 \\
0.9398 \\
1.2446 \\
1.0922\end{array}$ & $\begin{array}{l}4.230 \\
3.740 \\
5.022 \\
9.000 \\
6.805\end{array}$ & 5.759 \\
\hline 2 & $\begin{array}{l}0.5334 \\
0.5538 \\
0.5842 \\
0.4572 \\
0.4572\end{array}$ & $\begin{array}{l}1.573 \\
1.733 \\
1.900 \\
1.138 \\
1.138\end{array}$ & $\begin{array}{c}1.496 \\
. .\end{array}$ & $\left|\begin{array}{l}0.9398 \\
0.6604 \\
0.3890 \\
0.9144 \\
0.5334\end{array}\right|$ & $\begin{array}{l}5.022 \\
2.446 \\
4.487 \\
4.750 \\
1.573\end{array}$ & 3.655 & $\mid \begin{array}{l}0.7874 \\
0.9398 \\
1.241 .4 \\
1.1684 \\
1.1430\end{array}$ & $\begin{array}{l}3.437 \\
5.022 \\
6.000 \\
7.900 \\
7.459\end{array}$ & 5.963 \\
\hline 3 & $\begin{array}{l}0.4064 \\
0.5334 \\
0.5534 \\
0.5030 \\
0.5030\end{array}$ & $\begin{array}{l}0.386 \\
1.573 \\
1 . .573 \\
1.421 \\
1.421\end{array}$ & 1.575 & $\left|\begin{array}{l}0.6058 \\
0.3128 \\
0.7620 \\
0.7620 \\
0.7620\end{array}\right|$ & $\begin{array}{l}2.643 \\
3.740 \\
3.279 \\
3.279 \\
3.279\end{array}$ & 3.245 & $\begin{array}{l}0.8636 \\
0.8636 \\
0.3630 \\
0.9398 \\
0.9398\end{array}$ & $\begin{array}{l}4.230 \\
4.230 \\
4.230 \\
5.022 \\
5.022\end{array}$ & $4 \cdot .547$ \\
\hline 4 & $\begin{array}{l}0.5588 \\
0.4572 \\
0.5842 \\
0.4826 \\
0.4826\end{array}$ & $\begin{array}{l}1.733 \\
1.130 \\
1.900 \\
1 .<76 \\
1 . .276\end{array}$ & 1.464 & $\begin{array}{l}0.9398 \\
0.8390 \\
0.3040 \\
0.6604 \\
0.6604\end{array}$ & $\begin{array}{l}5.022 \\
4.487 \\
4.487 \\
2.446 \\
2.446\end{array}$ & 3.777 & $\begin{array}{l}0.9398 \\
0.9390 \\
1.0414 \\
1.0414 \\
1.1430\end{array}$ & $\begin{array}{l}5.022 \\
5.022 \\
6.000 \\
6.000 \\
7.459\end{array}$ & 5.901 \\
\hline 5 & $\begin{array}{l}0.5588 \\
0.5588 \\
0.5842 \\
0.5842 \\
0.5842\end{array}$ & $\begin{array}{l}1.735 \\
1.735 \\
1.900 \\
1.900 \\
1.900\end{array}$ & 1.833 & $\begin{array}{l}0.7620 \\
0.7620 \\
0.76 z 0 \\
0.81<0 \\
0.8128\end{array}$ & $\begin{array}{l}3.279 \\
3.279 \\
3.279 \\
3.740 \\
3.740\end{array}$ & 3.463 & $\begin{array}{l}0.3636 \\
0.9398 \\
0.3128 \\
1.0922 \\
1.2446\end{array}$ & $\begin{array}{l}4.230 \\
5.022 \\
3.740 \\
6.805 \\
9.000\end{array}$ & 5.759. \\
\hline
\end{tabular}


Wear Volume Vs Load

\begin{tabular}{|c|c|c|c|c|c|c|c|c|c|}
\hline & \multicolumn{3}{|c|}{$2.5 \mathrm{Kgs}$} & \multicolumn{3}{|c|}{$5 \mathrm{kgs}$} & \multicolumn{3}{|c|}{$10 \mathrm{kgs}$} \\
\hline $\begin{array}{l}\text { Test } \\
\text { No }\end{array}$ & $\begin{array}{l}\text { Scratch } \\
\text { Width } \\
\text { mm } \\
\end{array}$ & $\begin{array}{c}\text { Wear } \\
\text { volume } \\
\text { mm } 3\end{array}$ & $\begin{array}{l}\text { vear } \\
\text { volume } \\
\text { Averoge }\end{array}$ & $\begin{array}{c}\text { Scraich } \\
\text { Widith } \\
\text { in m }\end{array}$ & \begin{tabular}{|c|} 
Wear \\
volume \\
mm 3
\end{tabular} & $\begin{array}{l}\text { Wear } \\
\text { vislume } \\
\text { Avercoe }\end{array}$ & $\begin{array}{c}\text { Scrotich } \\
\text { width } \\
\mathrm{m} \mathrm{m}\end{array}$ & $\begin{array}{l}\text { Ylear } \\
\text { volume } \\
\text { mm } 3 \\
\end{array}$ & $\begin{array}{l}\text { Vyerr } \\
\text { Volume } \\
\text { Averoge }\end{array}$ \\
\hline 1 & $\begin{array}{l}0.2794 \\
0.3302 \\
0.3048 \\
0.3048 \\
0.2340\end{array}$ & $\begin{array}{l}0.384 \\
0.56 z \\
0.469 \\
0.469 \\
0.306\end{array}$ & 0.438 & $\begin{array}{l}0.4318 \\
0.5030 \\
0.5334 \\
0.5334 \\
0.457\end{array}$ & $\begin{array}{l}1.008 \\
1.4<1 \\
1.573 \\
1.573 \\
1.130\end{array}$ & 1.342 & $\begin{array}{l}0.7620 \\
0.7620 \\
0.711 z \\
0.0550 \\
0.6858\end{array}$ & $\begin{array}{l}3.279 \\
3.279 \\
2.848 \\
2.272 \\
2.643\end{array}$ & $=.870$ \\
\hline 2 & $\begin{array}{l}0.5030 \\
0.6350 \\
0.4826 \\
0.5334 \\
0.5334\end{array}$ & $\begin{array}{l}1.421 \\
2.272 \\
1.276 \\
1.573 \\
1.573\end{array}$ & 1.623 & $\begin{array}{l}0.6350 \\
0.8330 \\
0.7360 \\
0.8630 \\
0.8636\end{array}$ & $\left\{\begin{array}{l}2.27 z \\
3.981 \\
3.060 \\
4.230 \\
4.230\end{array}\right.$ & 3.554 & $\begin{array}{l}1.0160 \\
1.1430 \\
1.0160 \\
0.9398 \\
0.9906\end{array}$ & $\begin{array}{l}5.880 \\
7.459 \\
5.880 \\
5.022 \\
5.587\end{array}$ & 5.929 \\
\hline 3 & $\begin{array}{l}0.4318 \\
0.3302 \\
0.4064 \\
0.2794 \\
0.2794\end{array}$ & $\begin{array}{l}1.008 \\
0.562 \\
0.886 \\
0.384 \\
0.384\end{array}$ & 0.645 & $\begin{array}{l}0.4318 \\
0.4518 \\
0.6858 \\
0.4318 \\
0.4318\end{array}$ & $\left\{\begin{array}{l}1.008 \\
1.008 \\
2.043 \\
1.008 \\
1.008\end{array}\right.$ & 1.335 & $\left\{\begin{array}{l}0.8128 \\
0.8890 \\
0.9398 \\
0.8128 \\
0.9906\end{array}\right.$ & $\begin{array}{l}3.740 \\
4.487 \\
5.022 \\
3.740 \\
5.587\end{array}$ & 4.515 \\
\hline 4 & $\begin{array}{l}0.4318 \\
0.4318 \\
0.3810 \\
0.3550 \\
0.3536\end{array}$ & $\begin{array}{l}1.008 \\
1.008 \\
0.770 \\
0.605 \\
0.603\end{array}$ & 0.822 & $\begin{array}{l}0.7368 \\
0.5080 \\
0.4064 \\
0.4826 \\
0.48<6\end{array}$ & $\begin{array}{l}3.060 \\
1.421 \\
0.886 \\
1.276 \\
1.276\end{array}$ & 1.534 & $\begin{array}{l}0.7620 \\
0.6350 \\
0.7112 \\
0.6858 \\
.6850\end{array}$ & $\begin{array}{l}3.279 \\
2.272 \\
2.848 \\
\dot{c} .643 \\
\dot{c} .043\end{array}$ & $\varepsilon .735$ \\
\hline 5 & $\begin{array}{l}0.6096 \\
0.4572 \\
0.3556 \\
0.3556 \\
0.3556\end{array}$ & $\begin{array}{l}2.075 \\
1.130 \\
0.663 \\
0.663 \\
0.663\end{array}$ & 1.040 & $\begin{array}{l}0.6090 \\
0.5080 \\
0.6350 \\
0.5080 \\
0.7620\end{array}$ & $\begin{array}{l}2.075 \\
1.421 \\
2.272 \\
1.421 \\
3.279\end{array}$ & 2.093 & $\begin{array}{l}0.9348 \\
0.9398 \\
0.9652 \\
1.0414 \\
0.8890\end{array}$ & $\begin{array}{l}5.022 \\
5.022 \\
5.300 \\
6.000 \\
4.487\end{array}$ & 5.158 \\
\hline
\end{tabular}


Wear Volume Vs Load

\begin{tabular}{|c|c|c|c|c|c|c|c|c|c|}
\hline & \multicolumn{3}{|c|}{$2.5 \mathrm{kgs}$} & \multicolumn{3}{|c|}{$5 \mathrm{kgs}$} & \multicolumn{3}{|c|}{$10 \mathrm{Kgs}$} \\
\hline $\begin{array}{l}\text { Test } \\
\text { No } \\
\end{array}$ & $\begin{array}{c}\text { Scratch } \\
\text { Width } \\
\text { m m }\end{array}$ & \begin{tabular}{|l|} 
Wear \\
Volume \\
m m 3
\end{tabular} & \begin{tabular}{|l|} 
Wear \\
Volume \\
Average \\
\end{tabular} & $\begin{array}{c}\text { Scratch } \\
\text { Width } \\
\text { mm } \\
\end{array}$ & $\begin{array}{l}\text { Wear } \\
\text { Volume } \\
\text { mm } 3 \\
\end{array}$ & $\begin{array}{l}\text { Wear } \\
\text { Volume } \\
\text { Average }\end{array}$ & \begin{tabular}{|c|} 
Scratch \\
width \\
$\mathrm{mm}$ \\
\end{tabular} & \begin{tabular}{|l} 
Yrear \\
volume \\
mm?
\end{tabular} & $\begin{array}{l}\text { Wear } \\
\text { Volume } \\
\text { Averoge }\end{array}$ \\
\hline 1 & $\begin{array}{l}0.22886 \\
0.2286 \\
0.2236 \\
0.2540 \\
u .2540\end{array}$ & $\begin{array}{l}0.235 \\
0.235 \\
0.235 \\
0.306 \\
0.306\end{array}$ & 0.263 & $\begin{array}{l}0.2794 \\
0.4064 \\
0.3536 \\
0.4518 \\
0.5302\end{array}$ & $\begin{array}{l}0.384 \\
0.306 \\
0.605 \\
1.008 \\
0.562\end{array}$ & 0.600 & $\mid \begin{array}{l}0.3810 \\
0.4064 \\
0.5060 \\
0.5334 \\
0.3210\end{array}$ & $\begin{array}{l}0.770 \\
0.386 \\
1.421 \\
1.573 \\
0.770\end{array}$ & 1.078 \\
\hline 2 & $\begin{array}{l}0.2286 \\
0.2 z 86 \\
0.2 z 86 \\
0.2794 \\
0.2540\end{array}$ & $\begin{array}{l}0.235 \\
0.235 \\
0.235 \\
0.384 \\
0.306\end{array}$ & $\begin{array}{c}0.279 \\
. .\end{array}$ & $\begin{array}{l}0.3556 \\
0.3556 \\
0.3556 \\
0.3302 \\
0.3302\end{array}$ & $\begin{array}{l}0.663 \\
0.663 \\
0.663 \\
0.562 \\
0.562\end{array}$ & 0.622 & $\mid \begin{array}{l}0.4064 \\
0.4572 \\
0.4826 \\
0.4026 \\
0.5080\end{array}$ & $\begin{array}{l}0.836 \\
1.138 \\
1.276 \\
1.276 \\
1.421\end{array}$ & 1199 \\
\hline 3 & $\begin{array}{l}0.3302 \\
0.3302 \\
0.2540 \\
0.2540 \\
0.2286\end{array}$ & $\begin{array}{l}0.562 \\
0.562 \\
0.306 \\
0.306 \\
0.235\end{array}$ & 0.394 & $\begin{array}{l}0.3302 \\
0.3556 \\
0.4318 \\
0.3556 \\
0.3048\end{array}$ & $\begin{array}{l}0.562 \\
0.663 \\
1.008 \\
0.663 \\
0.469\end{array}$ & 0.673 & $\begin{array}{l}0.4064 \\
0.4572 \\
.3556 \\
0.4318 \\
0.4572\end{array}$ & $\begin{array}{l}0.836 \\
1.138 \\
0.663 \\
1.008 \\
1.138\end{array}$ & 0.966 \\
\hline 4 & $\begin{array}{l}0.2286 \\
0.2032 \\
0.2540 \\
0.2794 \\
0.2286\end{array}$ & $\begin{array}{l}0.235 \\
0.172 \\
0.306 \\
0.384 \\
0.235\end{array}$ & 0.266 & $\begin{array}{l}0.3556 \\
0.3556 \\
0.3556 \\
0.3556 \\
0.3556\end{array}$ & $\begin{array}{l}0.603 \\
0.663 \\
0.663 \\
0.663 \\
0.663\end{array}$ & 0.663 & $\begin{array}{l}0.4064 \\
.4064 \\
.4572 \\
.5080 \\
.5503\end{array}$ & $\begin{array}{l}0.886 \\
0.386 \\
1.138 \\
1.421 \\
1.733\end{array}$ & 1.213 \\
\hline 5 & $\begin{array}{l}0.2540 \\
.2794 \\
0.2032 \\
0.2032 \\
0.2032\end{array}$ & $\begin{array}{l}0.306 \\
0.304 \\
0.172 \\
0.172 \\
0.172\end{array}$ & 0.241 & $\mid \begin{array}{l}0.3302 \\
0.3302 \\
0.3048 \\
0.2794 \\
0.4572\end{array}$ & $\begin{array}{l}0.562 \\
0.562 \\
0.469 \\
0.384 \\
1.138\end{array}$ & 0.623 & $\begin{array}{l}0.355 \\
0.3810 \\
0.5080 \\
0.4571 \\
0.457\end{array}$ & $\begin{array}{l}0.663 \\
0.770 \\
1.421 \\
1.138 \\
1.138\end{array}$ & 1.026 \\
\hline
\end{tabular}


Wear Volume Vs Load

\begin{tabular}{|c|c|c|c|c|c|c|c|c|c|}
\hline & \multicolumn{3}{|c|}{$2.5 \mathrm{kgs}$} & \multicolumn{3}{|c|}{$5 \mathrm{kgs}$} & \multicolumn{3}{|c|}{$10 \mathrm{kgs}$} \\
\hline $\begin{array}{l}\text { Test } \\
\text { No }\end{array}$ & $\begin{array}{c}\text { Scratch } \\
\text { Width } \\
\text { m m }\end{array}$ & $\begin{array}{c}\text { Wear } \\
\text { volume } \\
\text { m m } 3\end{array}$ & $\begin{array}{l}\text { Woar } \\
\text { Volume } \\
\text { Average }\end{array}$ & $\begin{array}{l}\text { Scratch } \\
\text { Width } \\
\text { mm }\end{array}$ & $\begin{array}{l}\text { Wear } \\
\text { Yolume } \\
\text { mm } 3 \\
\end{array}$ & $\begin{array}{l}\text { Wear } \\
\text { Yolume } \\
\text { Avercge }\end{array}$ & \begin{tabular}{|c|} 
Scratich \\
width \\
$\mathrm{mm}$
\end{tabular} & $\begin{array}{l}\text { Wear } \\
\text { Volume } \\
\mathrm{mm} 3 \\
\end{array}$ & $\begin{array}{l}\text { Verr } \\
\text { Volume } \\
\text { averige }\end{array}$ \\
\hline 1 & $\mid \begin{array}{l}0.1524 \\
0.1778 \\
0.1778 \\
0.1524 \\
0.1524\end{array}$ & $\begin{array}{l}0.068 \\
0.116 \\
0.116 \\
0.068 \\
0.060\end{array}$ & 0.087 & $\begin{array}{l}0.1778 \\
0.3048 \\
0.2540 \\
0.2286 \\
0.2286\end{array}$ & $\begin{array}{l}0.116 \\
0.469 \\
0.306 \\
0.25 j \\
0.25 j\end{array}$ & 0.283 & $\begin{array}{l}0.3048 \\
0.350 z \\
0.2794 \\
0.330 z \\
0.3048\end{array}$ & $\begin{array}{l}0.469 \\
0.562 \\
0.504 \\
0.562 \\
0.469\end{array}$ & $=.489$ \\
\hline 2 & $\begin{array}{l}0.2540 \\
0.2540 \\
0.2286 \\
0.2286 \\
0.2032\end{array}$ & $\begin{array}{l}0.306 \\
0.306 \\
0.235 \\
0.235 \\
0.172\end{array}$ & $\begin{array}{c}0.250 \\
.\end{array}$ & $\begin{array}{l}0.3040 \\
0.2540 \\
0.2794 \\
0.2794 \\
0.2794\end{array}$ & $\begin{array}{l}0.402 \\
0.306 \\
0.384 \\
0.384 \\
0.384\end{array}$ & 0.384 & $\begin{array}{l}0.4826 \\
0.4318 \\
0.4313 \\
0.4064 \\
0.4318\end{array}$ & $\begin{array}{l}1.276 \\
1.008 \\
1.008 \\
0.386 \\
1.008\end{array}$ & 1.037 \\
\hline 3 & $\mid \begin{array}{l}0.2032 \\
0.2286 \\
0.2032 \\
0.1778 \\
0.1524\end{array}$ & $\begin{array}{l}0.172 \\
0.172 \\
0.172 \\
0.116 \\
0.068\end{array}$ & ن.152 & $\begin{array}{l}0.2286 \\
0.2540 \\
0.2754 \\
0.3302 \\
0.2286\end{array}$ & $\begin{array}{l}0.235 \\
0.306 \\
0.384 \\
0.562 \\
0.235\end{array}$ & 0.330 & $\begin{array}{l}0.4064 \\
0.4064 \\
0.3550 \\
0.3556 \\
0.3810\end{array}$ & $\begin{array}{l}0.886 \\
0.386 \\
0.663 \\
0.663 \\
0.770\end{array}$ & 0.773 \\
\hline 4 & $\begin{array}{l}0.2540 \\
0.2286 \\
0.2286 \\
0.2032 \\
0.1778\end{array}$ & $\begin{array}{l}0.306 \\
0.235 \\
0.235 \\
0.172 \\
0.116\end{array}$ & 0.213 & $\begin{array}{l}0.2286 \\
0.2286 \\
0.2540 \\
0.2794 \\
0.3306\end{array}$ & $\begin{array}{l}0.235 \\
0.235 \\
0.306 \\
0.384 \\
0.562\end{array}$ & 10.330 & $\begin{array}{l}0.3556 \\
u .3556 \\
u .3550 \\
0.3556 \\
u .3556\end{array}$ & $\begin{array}{l}0.663 \\
0.663 \\
0.663 \\
0.663 \\
0.663\end{array}$ & 0.663 \\
\hline 5 & $\begin{array}{l}0.1770 \\
0.1524 \\
0.1778 \\
0.2032 \\
0.1773\end{array}$ & $\begin{array}{l}0.116 \\
0.068 \\
0.116 \\
0.172 \\
0.116\end{array}$ & 0.117 & $\begin{array}{l}0.27 y 4 \\
0.2794 \\
0.2540 \\
0.2544 \\
0.3040\end{array}$ & $\begin{array}{l}0.384 \\
0.304 \\
0.306 \\
0.306 \\
0.462\end{array}$ & 0.368 & $\begin{array}{l}0.3556 \\
0.3810 \\
0.3302 \\
0.3048 \\
0.3302\end{array}$ & $\begin{array}{l}0.663 \\
0.770 \\
0.502 \\
0.402 \\
0.562\end{array}$ & 0.604 \\
\hline
\end{tabular}


Wear Volume Vs Load

\begin{tabular}{|c|c|c|c|c|c|c|c|c|c|}
\hline & \multicolumn{3}{|c|}{$2.5 \mathrm{Kgs}$} & \multicolumn{3}{|c|}{$5 \mathrm{Kgs}$} & \multicolumn{3}{|c|}{$10 \mathrm{kgs}$} \\
\hline $\begin{array}{l}\text { Test } \\
\text { No }\end{array}$ & $\begin{array}{c}\text { Scratch } \\
\text { Width } \\
\text { m m }\end{array}$ & \begin{tabular}{|c|} 
Wear \\
Volume \\
mm?
\end{tabular} & \begin{tabular}{|l|} 
Wear \\
volume \\
Avergge \\
\end{tabular} & \begin{tabular}{|c|} 
Scraich \\
Width \\
mm
\end{tabular} & \begin{tabular}{|l|} 
Wear \\
Volume \\
mm 3 \\
\end{tabular} & \begin{tabular}{|l|} 
Wear \\
Volume \\
Avercge \\
\end{tabular} & \begin{tabular}{|c|} 
Scratch \\
width \\
$\mathrm{m} \mathrm{m}$
\end{tabular} & $\begin{array}{l}\text { Wear } \\
\text { Volume } \\
\text { mm } 3\end{array}$ & $\begin{array}{l}\text { Wear } \\
\text { Volume } \\
\text { Average } \\
\end{array}$ \\
\hline 1 & $\begin{array}{l}0.3556 \\
0.3302 \\
0.3048 \\
0.3048 \\
0.3302\end{array}$ & $\begin{array}{l}0.663 \\
0.562 \\
0.469 \\
0.469 \\
0.562\end{array}$ & 0.545 & $\begin{array}{l}0.3550 \\
0.4318 \\
0.4318 \\
0.4572 \\
0.3810\end{array}$ & $\begin{array}{l}0.663 \\
1.008 \\
1.008 \\
1.138 \\
0.770\end{array}$ & 0.917 & $\mid \begin{array}{l}0.5080 \\
0.4064 \\
0.5354 \\
0.5334 \\
0.4318\end{array}$ & $\begin{array}{l}1.421 \\
0.886 \\
1.573 \\
1.573 \\
1.008\end{array}$ & $\because .292$ \\
\hline 2 & $\begin{array}{l}0.3048 \\
0.3302 \\
0.3302 \\
0.3302 \\
0.3556\end{array}$ & $\begin{array}{l}0.469 \\
0.562 \\
0.562 \\
0.562 \\
0.663\end{array}$ & $\begin{array}{c}0.563 \\
. .\end{array}$ & $\begin{array}{l}0.3550 \\
0.4318 \\
0.4310 \\
0.4578 \\
0.3810\end{array}$ & $\begin{array}{l}0.663 \\
1.008 \\
1.008 \\
1.138 \\
0.770\end{array}$ & 0.917 & $\begin{array}{l}0.6096 \\
0.5080 \\
0.6046 \\
0.7112 \\
0.4064\end{array}$ & $\begin{array}{l}2.075 \\
1.421 \\
2.075 \\
2.848 \\
0.886\end{array}$ & 1.861 \\
\hline 3 & $\begin{array}{l}0.3048 \\
0.3048 \\
0.3302 \\
0.3556 \\
0.2794\end{array}$ & $\begin{array}{l}0.469 \\
0.469 \\
0.562 \\
0.663 \\
0.384\end{array}$ & 0.509 & $\begin{array}{l}0.3048 \\
0.3810 \\
0.330 \\
0.330 \\
0.3010\end{array}$ & $\begin{array}{l}0.469 \\
0.770 \\
0.562 \\
0.562 \\
0.770\end{array}$ & 0.626 & $\begin{array}{l}0.4826 \\
0.4826 \\
0.4826 \\
0.6096 \\
0.4310\end{array}$ & $\begin{array}{l}1.276 \\
1.276 \\
1.276 \\
2.075 \\
1.008\end{array}$ & $1 . .382$ \\
\hline 4 & $\begin{array}{l}0.4064 \\
0.4064 \\
0.3302 \\
0.2540 \\
0.3556\end{array}$ & $\begin{array}{l}0.886 \\
0.836 \\
0.562 \\
0.306 \\
0.603\end{array}$ & 0.660 & $\begin{array}{l}0.3810 \\
0.330 \\
0.3810 \\
0.5080 \\
0.3819\end{array}$ & $\begin{array}{l}0.770 \\
0.562 \\
0.770 \\
1.421 \\
0.770\end{array}$ & 0.358 & $\begin{array}{l}0.5334 \\
0.6350 \\
0.3810 \\
0.3556 \\
0.5080\end{array}$ & $\begin{array}{l}1.573 \\
2.272 \\
0.770 \\
0.663 \\
1.421\end{array}$ & 1.339 \\
\hline 5 & $\begin{array}{l}0.3302 \\
0.2540 \\
0.2032 \\
0.3302 \\
0.4313\end{array}$ & $\begin{array}{l}0.362 \\
0.306 \\
0.172 \\
0.562 \\
1.008\end{array}$ & 0.522 & $\begin{array}{l}0.3810 \\
0.5080 \\
0.3550 \\
0.4064 \\
0.4064\end{array}$ & $\begin{array}{l}0.770 \\
1.421 \\
0.663 \\
0.886 \\
0.886\end{array}$ & 0.925 & $\left|\begin{array}{l}0.4572 \\
0.5334 \\
0.4310 \\
0.5030 \\
ن .4826\end{array}\right|$ & $\begin{array}{l}1.138 \\
1.573 \\
1.008 \\
1.421 \\
1.276\end{array}$ & 1.283 \\
\hline
\end{tabular}


Wear Volume Vs Load

\begin{tabular}{|c|c|c|c|c|c|c|c|c|c|}
\hline & \multicolumn{3}{|c|}{$2.5 \mathrm{kgs}$} & \multicolumn{3}{|c|}{$5 \mathrm{Kgs}$} & \multicolumn{3}{|c|}{$10 \mathrm{Kgs}$} \\
\hline $\begin{array}{l}\text { Test } \\
\text { No }\end{array}$ & $\begin{array}{c}\text { Scratch } \\
\text { Width } \\
\mathrm{mm}\end{array}$ & $\begin{array}{l}\text { Wear } \\
\text { volume } \\
\text { m m } 3\end{array}$ & $\begin{array}{l}\text { Vear } \\
\text { Volume } \\
\text { Average }\end{array}$ & $\begin{array}{c}\text { Scraich } \\
\text { Width } \\
\text { mm }\end{array}$ & $\begin{array}{l}\text { Wear } \\
\text { Yolume } \\
\text { mm } 3 \\
\end{array}$ & $\begin{array}{l}\text { Wear } \\
\text { Volurne } \\
\text { Avercge }\end{array}$ & $\begin{array}{c}\text { Scroich } \\
\text { widih } \\
\mathrm{mm} \\
\end{array}$ & $\begin{array}{l}\text { Year } \\
\text { Volume } \\
\mathrm{mm} 3 \\
\end{array}$ & $\begin{array}{l}\text { YVerr } \\
\text { Volume } \\
\text { Avernge }\end{array}$ \\
\hline 1 & $\begin{array}{l}0.2794 \\
0.27 y 4 \\
0.2794 \\
0.2540 \\
0.3556\end{array}$ & $\begin{array}{l}0.384 \\
0.384 \\
0.384 \\
0.306 \\
0.663\end{array}$ & $0.4 \overline{2} 2$ & $\begin{array}{l}0.3550 \\
0.3556 \\
0.3556 \\
0.3556 \\
0.3556\end{array}$ & $\begin{array}{l}0.663 \\
0.663 \\
0.663 \\
0.663 \\
0.663\end{array}$ & 0.663 & $\begin{array}{l}c .4826 \\
u .4026 \\
ن .4826 \\
0.4572 \\
0.4572\end{array}$ & $\begin{array}{l}1.276 \\
1.276 \\
1.276 \\
1.138 \\
1.138\end{array}$ & 1.220 \\
\hline 2 & $\begin{array}{l}0.3048 \\
0.3043 \\
0.3048 \\
0.2540 \\
0.2540\end{array}$ & $\begin{array}{l}0.462 \\
0.462 \\
0.462 \\
0.306 \\
0.306\end{array}$ & $\begin{array}{c}0.399 \\
.\end{array}$ & $\begin{array}{l}0.4064 \\
0.4064 \\
0.3556 \\
0.3550 \\
0.4572\end{array}$ & $\begin{array}{l}0.386 \\
0.886 \\
0.663 \\
0.663 \\
1.138\end{array}$ & 0.847 & $\begin{array}{l}0.5588 \\
0.5588 \\
0.4318 \\
0.4826 \\
0.5080\end{array}$ & $\begin{array}{l}1.733 \\
1.733 \\
1.008 \\
1.276 \\
1.421\end{array}$ & 1.434 \\
\hline 3 & $\begin{array}{l}0.2794 \\
0.2794 \\
0.2540 \\
0.2540 \\
0.3048\end{array}$ & $\begin{array}{l}0.384 \\
0.384 \\
0.306 \\
0.306 \\
0.462\end{array}$ & 0.368 & $\begin{array}{l}0.3556 \\
u .4064 \\
0.3556 \\
0.4064 \\
0.3556\end{array}$ & $\begin{array}{l}0.663 \\
0.886 \\
0.663 \\
0.886 \\
0.663\end{array}$ & 0.752 & $\begin{array}{l}0.4826 \\
0.4826 \\
0.5334 \\
0.4064 \\
0.5842\end{array}$ & $\begin{array}{l}1.276 \\
1.276 \\
1.573 \\
0.886 \\
1 . y 00\end{array}$ & 1.382 \\
\hline 4 & $\begin{array}{l}0.2540 \\
0.2540 \\
0.2794 \\
0.3048 \\
0.3040\end{array}$ & $\begin{array}{l}0.306 \\
0.306 \\
0.384 \\
0.462 \\
0.462\end{array}$ & 0.384 & $\begin{array}{l}0.3556 \\
0.3302 \\
0.3302 \\
0.3048 \\
0.3010\end{array}$ & $\begin{array}{l}0.663 \\
0.562 \\
0.562 \\
0.462 \\
0.770\end{array}$ & 0.604 & $\begin{array}{l}0.5500 \\
0.5334 \\
0.5080 \\
0.4572 \\
0.3810\end{array}$ & $\begin{array}{l}1.733 \\
1.573 \\
1.421 \\
1.138 \\
0.770\end{array}$ & 1.327 \\
\hline 5 & $\begin{array}{l}0.3048 \\
0.2744 \\
0.2794 \\
0.3302 \\
0.3556\end{array}$ & $\begin{array}{l}0.462 \\
0.384 \\
0.384 \\
0.562 \\
0.663\end{array}$ & 0.491 & $\begin{array}{l}0.4572 \\
0.3810 \\
0.3556 \\
0.3550 \\
0.3550\end{array}$ & $\begin{array}{l}1.138 \\
0.770 \\
0.633 \\
0.663 \\
0.663\end{array}$ & 0.779 & $\begin{array}{l}.4572 \\
.4064 \\
0.4318 \\
0.5334 \\
0.5588\end{array}$ & $\begin{array}{l}1.138 \\
0.886 \\
1.008 \\
1.573 \\
1.733\end{array}$ & 1.257 \\
\hline
\end{tabular}


Wear Volume Vs Load

\begin{tabular}{|c|c|c|c|c|c|c|c|c|c|}
\hline & \multicolumn{3}{|c|}{$2.5 \mathrm{kgs}$} & \multicolumn{3}{|c|}{$5 \mathrm{kgs}$} & \multicolumn{3}{|c|}{$10 \mathrm{Kgs}$} \\
\hline $\begin{array}{l}\text { Test } \\
\text { No }\end{array}$ & $\begin{array}{c}\text { Scratch } \\
\text { Width } \\
\text { m m }\end{array}$ & \begin{tabular}{|l|} 
Wear \\
Volume \\
$\mathrm{mm} 3$ \\
\end{tabular} & \begin{tabular}{|l|} 
Wear \\
Volume \\
Avergge \\
\end{tabular} & \begin{tabular}{c|} 
Scratch \\
Width \\
$\mathrm{mm}$ \\
\end{tabular} & \begin{tabular}{|l|} 
Wear \\
Volume \\
mm 3 \\
\end{tabular} & $\begin{array}{l}\text { Wear } \\
\text { Volume } \\
\text { Avercge }\end{array}$ & \begin{tabular}{|c|} 
Scratch \\
Width \\
$\mathrm{mm}$
\end{tabular} & $\begin{array}{l}\text { Wear } \\
\text { Volume } \\
\text { mm } 3 \\
\end{array}$ & $\begin{array}{l}\text { Wear } \\
\text { Volume } \\
\text { Average }\end{array}$ \\
\hline 1 & $\begin{array}{l}0.3556 \\
0.4318 \\
0.4064 \\
0.2794 \\
0.3556\end{array}$ & $\begin{array}{l}0.663 \\
1.008 \\
0.306 \\
0.384 \\
0.663\end{array}$ & 0.720 & $\begin{array}{c}0.4064 \\
0.5534 \\
0.5842 \\
0.5030 \\
0.4572\end{array}$ & $\begin{array}{l}0.886 \\
1.573 \\
1.900 \\
1.421 \\
1.138\end{array}$ & 1.383 & $\begin{array}{l}0.6096 \\
0.9393 \\
0.5842 \\
0.6096 \\
0.6858\end{array}$ & $\begin{array}{l}2.075 \\
5.022 \\
1.900 \\
2.075 \\
2.045\end{array}$ & $\hat{2} .743$ \\
\hline 2 & $\begin{array}{l}0.3302 \\
0.3302 \\
0.4572 \\
0.2794 \\
0.3048\end{array}$ & $\begin{array}{l}0.562 \\
0.562 \\
1.138 \\
0.384 \\
0.469\end{array}$ & 0.623 & $\begin{array}{l}0.3810 \\
0.3556 \\
0.4026 \\
0.5842 \\
0.4064\end{array}$ & $\begin{array}{l}0.770 \\
0.663 \\
1.276 \\
1.900 \\
0.886\end{array}$ & 1.099 & $\begin{array}{l}0.5842 \\
0.8128 \\
0.5080 \\
0.4572 \\
0.4572\end{array}$ & $\begin{array}{l}1.900 \\
3.740 \\
1.421 \\
1.138 \\
1.138\end{array}$ & 1.667 \\
\hline-3 & $\begin{array}{l}0.5080 \\
0.4826 \\
0.4572 \\
0.4828 \\
0.4572\end{array}$ & $\begin{array}{l}1.421 \\
1.276 \\
1.238 \\
1.276 \\
1.138\end{array}$ & 1.249 & $\begin{array}{l}0.5334 \\
0.5583 \\
0.5588 \\
0.6604 \\
0.6350\end{array}$ & $\begin{array}{l}1.573 \\
1.733 \\
1.733 \\
2.446 \\
2.272\end{array}$ & 1.951 & $\begin{array}{l}0.8382 \\
0.8128 \\
0.8128 \\
0.9390 \\
0.5080\end{array}$ & $\begin{array}{l}3.981 \\
3.740 \\
3.740 \\
5.022 \\
1.421\end{array}$ & 3.580 \\
\hline 4 & $\begin{array}{l}0.5583 \\
0.5842 \\
0.6096 \\
0.4064 \\
0.4064\end{array}$ & $\begin{array}{l}1.733 \\
1.900 \\
2.075 \\
0.886 \\
0.386\end{array}$ & 1.496 & $\begin{array}{l}0.6350 \\
0.6350 \\
0.6858 \\
0.6604 \\
0.7520\end{array}$ & $\begin{array}{l}z .272 \\
z .272 \\
z .643 \\
z .446 \\
3.279\end{array}$ & $\ddot{c} .582$ & $\begin{array}{l}.8390 \\
.8636 \\
.9906 \\
.7874 \\
0.7360\end{array}$ & $\begin{array}{l}4.487 \\
4.230 \\
5.587 \\
3.437 \\
3.060\end{array}$ & 4.160 \\
\hline 5 & $\begin{array}{l}0.3556 \\
0.3556 \\
0.3556 \\
0.3556 \\
0.3556\end{array}$ & $\begin{array}{l}0.663 \\
0.663 \\
0.663 \\
0.663 \\
0.603\end{array}$ & 0.663 & $\begin{array}{l}0.4572 \\
0.5588 \\
0.5588 \\
0.4826 \\
0.60 y 6\end{array}$ & $\begin{array}{l}1.138 \\
1.733 \\
1.753 \\
1.276 \\
2.075\end{array}$ & 1.591 & $\begin{array}{l}.5080 \\
.7620 \\
.6358 \\
.7620 \\
.5588\end{array}$ & $\begin{array}{l}1.421 \\
3.279 \\
2.643 \\
3.279 \\
1.773\end{array}$ & $=.479$ \\
\hline
\end{tabular}


Wear Volume Vs Load

\begin{tabular}{|c|c|c|c|c|c|c|c|c|c|}
\hline & \multicolumn{3}{|c|}{$2.5 \mathrm{kgs}$} & \multicolumn{3}{|c|}{$5 \mathrm{Kgs}$} & \multicolumn{3}{|c|}{$10 \mathrm{kgs}$} \\
\hline $\begin{array}{l}\text { Test } \\
\text { No }\end{array}$ & $\begin{array}{c}\text { Scratch } \\
\text { Width } \\
\mathrm{mm}\end{array}$ & \begin{tabular}{|l} 
Wear \\
volume \\
mm 3
\end{tabular} & \begin{tabular}{|l|} 
Wear \\
Volume \\
Average
\end{tabular} & $\begin{array}{l}\text { Scrotch } \\
\text { Width } \\
\text { inm }\end{array}$ & $\begin{array}{l}\text { Wear } \\
\text { Yolume } \\
\text { mm } 3 \\
\end{array}$ & $\begin{array}{l}\text { Weor } \\
\text { volume } \\
\text { Avercoge }\end{array}$ & $\begin{array}{c}\text { Scroich } \\
\text { width } \\
\text { mm } \\
\end{array}$ & $\begin{array}{l}\text { Year } \\
\text { Yolume } \\
\text { mm } 3 \\
\end{array}$ & $\begin{array}{l}\text { Vear } \\
\text { Volume } \\
\text { Average }\end{array}$ \\
\hline 1 & $\begin{array}{l}0.4064 \\
0.3048 \\
0.4064 \\
0.4826 \\
0.4572\end{array}$ & $\begin{array}{l}0.886 \\
0.469 \\
0.086 \\
1.276 \\
1.138\end{array}$ & 0.931 & $\begin{array}{l}u .5580 \\
0.4572 \\
0.5342 \\
0.4826 \\
0.4326\end{array}$ & $\begin{array}{l}1.733 \\
1.138 \\
1.900 \\
1.276 \\
1.276\end{array}$ & 1.464 & $\begin{array}{l}0.5308 \\
0.5334 \\
0.6004 \\
0.7366 \\
0.5508\end{array}$ & $\begin{array}{l}1.733 \\
1.573 \\
2.446 \\
3.060 \\
1.733\end{array}$ & $E .109$ \\
\hline 2 & $\begin{array}{l}0.5080 \\
0.5080 \\
.3556 \\
0.4064 \\
.4064\end{array}$ & $\begin{array}{l}1.421 \\
1.421 \\
0.663 \\
0.886 \\
0.886\end{array}$ & $\begin{array}{c}1.055 \\
. .\end{array}$ & $\begin{array}{l}0.4826 \\
0.4826 \\
0.5588 \\
0.5342 \\
0.5334\end{array}$ & $\begin{array}{l}1.276 \\
1.276 \\
1.733 \\
1.900 \\
1.573\end{array}$ & 1.551 & $\begin{array}{l}0.6858 \\
0.6858 \\
0.6858 \\
0.7112 \\
0.7112\end{array}$ & $\begin{array}{l}2.643 \\
2.643 \\
2.643 \\
2.848 \\
2.848\end{array}$ & $k .725$ \\
\hline 3 & $\begin{array}{l}0.3048 \\
.4826 \\
.5080 \\
.4064 \\
.3810\end{array}$ & $\begin{array}{l}0.469 \\
1.276 \\
1.421 \\
0.886 \\
0.770\end{array}$ & 0.964 & $\begin{array}{l}0.4826 \\
0.5334 \\
0.6096 \\
0.6096 \\
0.4826\end{array}$ & $\begin{array}{l}1.276 \\
1.573 \\
2.075 \\
2.075 \\
1.276\end{array}$ & 1.655 & $\begin{array}{l}.5842 \\
.7620 \\
.6858 \\
.8128 \\
.5080\end{array}$ & $\begin{array}{l}1.900 \\
3.279 \\
2.643 \\
3.740 \\
1.421\end{array}$ & $=.596$ \\
\hline 4 & $\begin{array}{l}.3556 \\
.3556 \\
.3556 \\
.4064 \\
.4064\end{array}$ & $\begin{array}{l}0.663 \\
0.663 \\
0.603 \\
0.336 \\
0.036\end{array}$ & 0.752 & $\begin{array}{l}0.3010 \\
0.4064 \\
0.3556 \\
0.3810 \\
0.4310\end{array}$ & $\begin{array}{l}0.770 \\
0.386 \\
0.663 \\
0.770 \\
1.008\end{array}$ & 0.819 & $\begin{array}{l}.4318 \\
.5080 \\
.5842 \\
.5588 \\
.7366\end{array}$ & $\begin{array}{l}1.008 \\
1.421 \\
1.900 \\
1.733 \\
3.060\end{array}$ & 1.824 \\
\hline 5 & $\begin{array}{l}0.4064 \\
0.4064 \\
0.4064 \\
0.4518 \\
.4318\end{array}$ & $\begin{array}{l}0.886 \\
0.086 \\
0.386 \\
1.008 \\
1.008\end{array}$ & 0.931 & $\begin{array}{l}0.4826 \\
0.4326 \\
0.4064 \\
0.5334 \\
0.5842\end{array}$ & $\begin{array}{l}1.276 \\
1.276 \\
0.886 \\
1.573 \\
1.900\end{array}$ & 1.382 & $\begin{array}{l}0.5334 \\
.5334 \\
.6350 \\
.6858 \\
.7112\end{array}$ & $\left\{\begin{array}{l}1.573 \\
1.573 \\
2.272 \\
2.643 \\
c .848\end{array}\right.$ & $\$ .182$ \\
\hline
\end{tabular}


Table 35

Wear Volume Vs Load

\begin{tabular}{|c|c|c|c|c|c|c|c|c|c|}
\hline & \multicolumn{3}{|c|}{$2.5 \mathrm{kgs}$} & \multicolumn{3}{|c|}{$5 \mathrm{kgs}$} & \multicolumn{3}{|c|}{$10 \mathrm{kgs}$} \\
\hline $\begin{array}{l}\text { Test } \\
\text { No } \\
\end{array}$ & $\begin{array}{c}\text { Scratich } \\
\text { Width } \\
\text { mm }\end{array}$ & $\begin{array}{l}\text { Wear } \\
\text { Volume } \\
\mathrm{mm} 3 \\
\end{array}$ & $\begin{array}{l}\text { Wear } \\
\text { Volume } \\
\text { Avergge }\end{array}$ & \begin{tabular}{|c|} 
Scratch \\
Width \\
mm
\end{tabular} & $\begin{array}{l}\text { Wear } \\
\text { Volume } \\
\text { mm } 3 \\
\end{array}$ & $\begin{array}{l}\text { Wear } \\
\text { Volume } \\
\text { Avercge }\end{array}$ & $\begin{array}{l}\text { Scritch } \\
\text { width } \\
\mathrm{mm}\end{array}$ & $\begin{array}{l}\text { Wear } \\
\text { volume } \\
\text { mm } 3 \\
\end{array}$ & $\begin{array}{l}\text { Went } \\
\text { Volume } \\
\text { Avernge }\end{array}$ \\
\hline 1 & $\begin{array}{l}0.4826 \\
0.7366 \\
0.5334 \\
0.4826 \\
0.4064\end{array}$ & $\begin{array}{l}1.276 \\
3.060 \\
1.573 \\
1.276 \\
0.806\end{array}$ & 1.614 & $\begin{array}{l}0.7874 \\
0.7620 \\
0.8382 \\
0.8636 \\
0.8636\end{array}$ & $\begin{array}{l}3.457 \\
3.279 \\
3.981 \\
4.230 \\
4.230\end{array}$ & 5.831 & $\begin{array}{l}0.9906 \\
1.2192 \\
0.9906 \\
1.0922 \\
1.1684\end{array}$ & $\begin{array}{l}5.587 \\
3.496 \\
5.537 \\
6.805 \\
7.000\end{array}$ & 6.695 \\
\hline 2 & $\begin{array}{l}0.6858 \\
0.3128 \\
.7620 \\
0.7620 \\
.5842\end{array}$ & $\begin{array}{l}2.643 \\
3.740 \\
3.279 \\
3.279 \\
1.900\end{array}$ & $\begin{array}{c}2.968 \\
. .\end{array}$ & $\begin{array}{l}0.7824 \\
0.838 z \\
0.7112 \\
1.0160 \\
0.858 z\end{array}$ & $\begin{array}{l}3.437 \\
3.931 \\
2.848 \\
5.880 \\
3.981\end{array}$ & 4.025 & $\begin{array}{l}-.092 z \\
.2446 \\
.8636 \\
.9398 \\
.1938\end{array}$ & $\begin{array}{l}6.305 \\
9.000 \\
4.230 \\
5.022 \\
8.000\end{array}$ & 6.611 \\
\hline-3 & $\begin{array}{l}0.6858 \\
0.6096 \\
0.7874 \\
.7874 \\
.6858\end{array}$ & $\begin{array}{l}2.643 \\
2.075 \\
3.437 \\
3.437 \\
2.643\end{array}$ & 2.037 & $\begin{array}{l}0.8128 \\
0.8890 \\
0.9398 \\
0.7874 \\
0.8890\end{array}$ & $\begin{array}{l}3.174 \\
4.487 \\
5.022 \\
3.437 \\
4.487\end{array}$ & 4.121 & $\begin{array}{l}.9144 \\
.3390 \\
.2446 \\
1.1684 \\
.1176\end{array}$ & $\begin{array}{l}4.750 \\
4.487 \\
9.000 \\
7.000 \\
6.900\end{array}$ & $5.4 \approx 2$ \\
\hline 4 & $\begin{array}{l}0.9398 \\
0.6604 \\
0.8390 \\
0.9144 \\
0.5334\end{array}$ & $\begin{array}{l}5.022 \\
2.446 \\
4.437 \\
4.750 \\
1.573\end{array}$ & 3.655 & $\begin{array}{l}0.7874 \\
0.9390 \\
1.0414 \\
1.1684 \\
1.1430\end{array}$ & $\begin{array}{l}3.437 \\
5.022 \\
6.000 \\
7.900 \\
7.459\end{array}$ & 3.963 & $\begin{array}{l}.2192 \\
1.2954 \\
1.1430 \\
1.0414 \\
1.0160\end{array}$ & $\begin{array}{l}0.496 \\
9.600 \\
7.459 \\
6.000 \\
5.880\end{array}$ & 7.485 \\
\hline 5 & $\begin{array}{l}0.60 y 6 \\
0.6858 \\
0.5588 \\
0.6858 \\
0.5334\end{array}$ & $\begin{array}{l}2.075 \\
2.643 \\
1.733 \\
2.643 \\
1.573\end{array}$ & 2.133 & $\begin{array}{l}0.9906 \\
1.1684 \\
1.1430 \\
1.1430 \\
0.4906\end{array}$ & $\begin{array}{l}5.587 \\
8.000 \\
7.459 \\
7.459 \\
5.587\end{array}$ & 6.818 & $\begin{array}{l}0.7874 \\
1.2192 \\
1.2446 \\
1.1176 \\
1.1430\end{array}$ & $\begin{array}{l}3.437 \\
8.496 \\
9.000 \\
6.900 \\
7.459\end{array}$ & 7.058 \\
\hline
\end{tabular}


Wear Volume Vs Load

\begin{tabular}{|c|c|c|c|c|c|c|c|c|c|}
\hline & \multicolumn{3}{|c|}{$2.5 \mathrm{kgs}$} & \multicolumn{3}{|c|}{$5 \mathrm{Kgs}$} & \multicolumn{3}{|c|}{$10 \mathrm{Kgs}$} \\
\hline \begin{tabular}{|l} 
Test \\
No \\
\end{tabular} & $\begin{array}{c}\text { Scratch } \\
\text { Width } \\
\text { mm }\end{array}$ & $\begin{array}{c}\text { Wear } \\
\text { Volume } \\
\text { mm } 3\end{array}$ & \begin{tabular}{|l|} 
vear \\
volume \\
Average \\
\end{tabular} & \begin{tabular}{|c|} 
Seratch \\
Widith \\
mm
\end{tabular} & $\begin{array}{l}\text { Wear } \\
\text { Yolume } \\
\text { mm } 3 \\
\end{array}$ & $\begin{array}{l}\text { Wear } \\
\text { Volume } \\
\text { Avercge }\end{array}$ & \begin{tabular}{|c|} 
Scratch \\
width \\
$\mathrm{mm}$ \\
\end{tabular} & $\begin{array}{l}\text { Vear } \\
\text { Volume } \\
\text { mm } 3 \\
\end{array}$ & $\begin{array}{l}\text { Viear } \\
\text { Volume } \\
\text { Averige } \\
\end{array}$ \\
\hline 1 & $\begin{array}{l}0.4572 \\
0.4572 \\
0.5334 \\
0.5080 \\
0.4318\end{array}$ & $\begin{array}{l}1.138 \\
1.138 \\
1.573 \\
1.421 \\
1.008\end{array}$ & 1.255 & $\left|\begin{array}{c}0.6604 \\
0.7874 \\
0.5842 \\
0.6850 \\
0.7620\end{array}\right|$ & $\begin{array}{l}2.446 \\
3.437 \\
1.900 \\
2.643 \\
3.279\end{array}$ & 2.741 & $\mid \begin{array}{l}0.6858 \\
0.8123 \\
0.8382 \\
0.8890 \\
0.7874\end{array}$ & $\begin{array}{l}2.643 \\
3.740 \\
3.931 \\
4.487 \\
3.457\end{array}$ & 3.655 \\
\hline 2 & $\begin{array}{l}0.4826 \\
0.5842 \\
0.6096 \\
0.4326 \\
0.4826\end{array}$ & $\begin{array}{l}1.276 \\
1.900 \\
2.075 \\
1.276 \\
1.276\end{array}$ & $\begin{array}{c}1.500 \\
. .\end{array}$ & $\begin{array}{l}0.5334 \\
0.5533 \\
0.6353 \\
0.8302 \\
0.7366\end{array}$ & $\begin{array}{l}1.573 \\
1.733 \\
2.643 \\
3.981 \\
3.060\end{array}$ & $\tilde{z} .618$ & $\mid \begin{array}{l}0.9144 \\
0.9144 \\
0.8390 \\
0.7620 \\
0.7620\end{array}$ & $\begin{array}{l}4.750 \\
4.750 \\
4.487 \\
3.279 \\
3.279\end{array}$ & 4.109 \\
\hline 3 & $\begin{array}{l}0.3810 \\
0.4064 \\
0.4318 \\
0.4826 \\
0.4318\end{array}$ & $\begin{array}{l}0.770 \\
0.886 \\
1.008 \\
1.276 \\
1.008\end{array}$ & 0.989 & $\mid \begin{array}{l}0.4572 \\
0.7112 \\
0.6350 \\
0.5354 \\
0.5334\end{array}$ & $\begin{array}{l}1.138 \\
2.848 \\
2.272 \\
1.573 \\
1.573\end{array}$ & 1.880 & $\mid \begin{array}{l}0.7874 \\
0.7620 \\
0.6096 \\
0.8636 \\
0.6858\end{array}$ & $\begin{array}{l}3.437 \\
3.279 \\
2.075 \\
4.230 \\
2.643\end{array}$ & 3.132 \\
\hline 4 & $\begin{array}{l}0.4064 \\
0.5334 \\
0.5842 \\
0.5080 \\
0.4572\end{array}$ & $\begin{array}{l}0.886 \\
1.573 \\
1.900 \\
1.421 \\
1.138\end{array}$ & 1.383 & $\mid \begin{array}{c}0.6058 \\
0.8128 \\
0.7620 \\
0.7620 \\
0.5842\end{array}$ & $\begin{array}{l}2.643 \\
3.740 \\
3.279 \\
3.279 \\
1.900\end{array}$ & $\dot{2} .968$ & $\begin{array}{l}0.7874 \\
0.7620 \\
0.838 \hat{c} \\
0.3636 \\
0.8636\end{array}$ & $\begin{array}{l}3.437 \\
3.279 \\
3.981 \\
4.230 \\
4.230\end{array}$ & 3.831 \\
\hline 5 & $\begin{array}{l}0.5842 \\
0.8128 \\
0.5080 \\
0.4572 \\
0.4572\end{array}$ & $\begin{array}{l}1.900 \\
3.740 \\
1.421 \\
1.138 \\
1.138\end{array}$ & 1.667 & $\begin{array}{l}0.6096 \\
0.9398 \\
0.5840 \\
0.6096 \\
0.6850\end{array}$ & $\begin{array}{l}2.075 \\
5.022 \\
1.900 \\
2.075 \\
2.643\end{array}$ & 2.743 & $\begin{array}{l}0.7824 \\
0.8382 \\
0.7112 \\
1.0160 \\
0.8382\end{array}$ & $\begin{array}{l}3.457 \\
3.931 \\
2.848 \\
5.880 \\
3.981\end{array}$ & 4.025 \\
\hline
\end{tabular}


APPENDIX 3

4 
Table 37

\begin{tabular}{|c|c|c|c|c|c|c|c|c|c|}
\hline \multicolumn{2}{|c|}{$\begin{array}{c}\text { Test ivo } \\
1\end{array}$} & \multicolumn{2}{|c|}{$\begin{array}{c}\text { Test ino } \\
2\end{array}$} & \multicolumn{2}{|c|}{$\begin{array}{c}\text { Test No } \\
3\end{array}$} & \multicolumn{2}{|c|}{$\begin{array}{c}\text { Test ivo } \\
4\end{array}$} & \multicolumn{2}{|c|}{$\begin{array}{c}\text { Pest No } \\
5\end{array}$} \\
\hline $\begin{array}{l}\text { Depth } \\
\text { mm }\end{array}$ & $\mathrm{HV}$ & $\begin{array}{l}\text { Jepth } \\
\mathrm{mm}\end{array}$ & $\mathrm{Hi}$. & $\underset{\text { mm }}{\text { Depth }}$ & $\mathrm{HV}$ & $\begin{array}{c}\text { Depth } \\
\text { ram }\end{array}$ & HV & $\underset{m}{\text { Deptin }}$ & $\mathrm{HV}$ \\
\hline .076 & 660 & .076 & 660 & .096 & 686 & IOI & 600 & .076 & 686 \\
\hline .123 & 742 & .152. & 772 & .152 & 772 & .123 & 686 & .152 & 7.42 \\
\hline .203 & 742 & .203 & 742 & .228 & 772 & .254 & 606 & .228 & 742 \\
\hline .340 & 686 & .254 & 742 & .330 & 742 & .330 & 686 & .381 & 742 \\
\hline .381 & 600 & .330 & 686 & .381 & 742 & .482 & 660 & .482 & 686 \\
\hline .482 & 462 & .406 & 482 & .431 & $48 z$ & .505 & $46 ?$ & .584 & 467 \\
\hline .558 & 245 &. .558 & 230 & .482 & 245 & .558 & 467. & .660 & 467 \\
\hline .736 & 214 & .660 & 224 & .558 & 297 & .660 & $29 ?$ & .785 & 297 \\
\hline .787 & 214 & .785 & 224 & .787 & 245 & .787 & 230 & .938 & 245 \\
\hline 1.041 & 214 & .938 & 224 & 1.041 & 224 & 1.114 & 230 & 1.041 & 230 \\
\hline
\end{tabular}

Thermal Spraying

1 Layer Deposit

Macro Hardness

Table 38

\begin{tabular}{|c|c|c|c|c|c|c|c|c|c|}
\hline \multicolumn{2}{|c|}{$\begin{array}{c}\text { Test No } \\
1\end{array}$} & \multicolumn{2}{|c|}{$\begin{array}{r}\text { Test No } \\
2\end{array}$} & \multicolumn{2}{|c|}{$\frac{\text { Test }}{3}$ No } & \multicolumn{2}{|c|}{$\begin{array}{c}\text { Test No } \\
4\end{array}$} & \multicolumn{2}{|c|}{$\begin{array}{c}\text { Test No } \\
5\end{array}$} \\
\hline$\underset{\mathrm{mm}}{\text { Depth }}$ & EV & $\begin{array}{c}\text { Depth } \\
\mathrm{mm}\end{array}$ & $\mathrm{HV}$ & $\underset{\min }{\text { Deptil }}$ & $\mathrm{HV}$ & $\underset{\text { men }}{\text { Depth }}$ & $\mathrm{HV}$ & $\underset{\mathrm{mm}}{\text { Depth }}$ & HV \\
\hline .076 & 772 & .076 & 836 & .098 & 876 & .101 & $876^{\circ}$ & .098 & 839 \\
\hline .123 & 095 & .136 & 831 & $.14 \ddot{2}$ & 876 & .152 & 876 & .177 & 713 \\
\hline .203 & 861 & .203 & 772 & .223 & 772 & .228 & 876 & .228 & 876 \\
\hline. .330 & 772 & .340 & 742 & .330 & 772 & .381 & 742 & .290 & 772 \\
\hline .482 & 496 & .482 & 572 & .432 & 482 & .406 & 453 & $\cdot 381$ & 482 \\
\hline .660 & 321 & .558 & 283 & .558 & 321 & .482 & 321 & .482 & 378 \\
\hline .785 & 263 & .787 & 257 & .711 & 263 & .584 & 276 & .558 & 276 \\
\hline .965 & 2334 & .938 & 234 & 1.041 & 234 & .736 & 321 & .787 & 297 \\
\hline 1.041 & 234 & 1.041 & 234 & 1.270 & 234 & 1.041 & 245 & 1.041 & 245 \\
\hline 1.422 & 224 & 1.401 & 214 & 1.422 & 224 & 1.401 & 214 & 1.444 & 224 \\
\hline
\end{tabular}




\begin{tabular}{|c|c|c|c|c|c|c|c|c|c|}
\hline \multicolumn{2}{|c|}{$\begin{array}{c}\text { Test ifo } \\
1\end{array}$} & \multicolumn{2}{|c|}{ liest ilo } & \multicolumn{2}{|c|}{$\begin{array}{c}\text { l'est No } \\
3\end{array}$} & \multicolumn{2}{|c|}{$\begin{array}{c}\text { PeEt wo } \\
4\end{array}$} & \multicolumn{2}{|c|}{$\because \because \frac{\pi t}{5}$} \\
\hline $\begin{array}{l}\text { Dejth } \\
\mathrm{mm}\end{array}$ & IVV & $\underset{m m}{D e p t h}$ & $\mathrm{HiV}$ & $\begin{array}{c}D \in N \tau \text { in } \\
\text { ara }\end{array}$ & $\mathrm{IiV}$ & $\underset{\min }{D e_{j} \operatorname{th}}$ & iv & Dejth & $\mathrm{SV}$ \\
\hline .152 & 606 & .152 & .772 & $: 15 \ddot{2}$ & 039 & .177 & 772 & .152 & $77 \bar{z}$ \\
\hline.$\dot{2} 28$ & 036 & . ச்َ & 839 & $. \dot{C}<I$ & 059 & .546 & $74 \ddot{z}$ & .231 & $77 z$ \\
\hline .381 & 636 & .346 & 839 & نَن & $77 \ddot{z}$ & . 3ól & 686 & .381 & $77 \bar{z}$ \\
\hline .508 & 453 & .600 & 636 & .482 & 606 & .505 & 533 & .534 & 686 \\
\hline .863 & 453 & .787 & 686 & .508 & 772 & .600 & 533 & .660 & 686 \\
\hline .965 & 578 & I. Ėl9 & 330 & 1.016 & 606 & .965 & 297 & 1.066 & 533 \\
\hline 1.219 & 378 & 1.346 & 378 & 1.117 & 533 & 1.114 & $26 y$ & $1.21 y$ & 482 \\
\hline 1.472 & 251 & 1.549 & 269 & 1.346 & 269 & 1.346 & 269 & 1.422 & 276 \\
\hline 1.600 & 229 & 1.600 & 251 & 1.422 & 251 & 1.549 & 245 & 1.574 & 276 \\
\hline 2.108 & 224 & 1.959 & 219 & 1.600 & 245 & $1.95 y$ & $\ddot{z} \dot{y}$ & 2.108 & 229 \\
\hline
\end{tabular}

Table 40

\begin{tabular}{|c|c|c|c|c|c|c|c|c|c|}
\hline \multicolumn{2}{|c|}{$\begin{array}{c}\text { Test No } \\
1\end{array}$} & \multicolumn{2}{|c|}{$\begin{array}{r}\text { iest io } \\
2\end{array}$} & \multicolumn{2}{|c|}{$\begin{array}{c}\text { Test } 10 \\
3\end{array}$} & \multicolumn{2}{|c|}{$\begin{array}{c}\text { iest ivo } \\
4\end{array}$} & \multicolumn{2}{|c|}{$\begin{array}{c}\text { Test iNo } \\
5\end{array}$} \\
\hline $\begin{array}{l}\text { jepth } \\
\text { Inm }\end{array}$ & $\mathrm{HV}$ & Dejth & $\because: V$ & $\begin{array}{l}\text { Deptin } \\
\text { mm }\end{array}$ & $i \in V$ & $\begin{array}{c}\text { Depth } \\
\text { min }\end{array}$ & $\mathrm{HV}$ & $\underset{\text { meph }}{\text { Depth }}$ & $\dddot{i} \mathrm{~V}$ \\
\hline .101 & 772 & $.15 \hat{z}$ & $y 16$ & .177 & 876 & .152 & 839 & .101 & 839 \\
\hline .228 & 772 & .281 & 1003 & .281 & 876 & .546 & 339 & .281 & 916 \\
\hline .301 & 742 & .381 & 839 & .301 & 686 & .444 & 805 & .381 & 916 \\
\hline .482 & 686 & .508 & 713 & .482 & 636 & .508 & 686 & .508 & 805 \\
\hline .508 & 085 & .990 & 630 & .548 & 533 & .914 & 636 & .863 & 686 \\
\hline .965 & 533 & 1.066 & $57 I$ & .990 & 453 & $.9 y 0$ & 453 & 1.117 & 482 \\
\hline 1.346 & 378 & 1.214 & 378 & 1.219 & 453 & 1.117 & 453 & 1.371 & 453 \\
\hline 1.549 & 305 & 1.498 & 312 & 1.498 & 305 & 1.778 & 239 & 2.362 & 257 \\
\hline 2.108 & 251 & 2.362 & 235 & 2.306 & 313 & 2.302 & $22 y$ & 2.540 & 230 \\
\hline 2.489 & $2 \overline{2} \overline{9}$ & 2.540 & 224 & 2.794 & 224 & 2.540 & $22 y$ & 2.794 & .218 \\
\hline
\end{tabular}


Table 41

\begin{tabular}{|c|c|c|c|c|c|c|c|c|c|}
\hline \multicolumn{2}{|c|}{$\begin{array}{c}\text { Test So } \\
1\end{array}$} & \multicolumn{2}{|c|}{$\begin{array}{c}\text { rest No } \\
2\end{array}$} & \multicolumn{2}{|c|}{$\begin{array}{c}\text { Tesi ito } \\
3\end{array}$} & \multicolumn{2}{|c|}{$\begin{array}{c}\text { Test ino } \\
4\end{array}$} & \multicolumn{2}{|c|}{$\begin{array}{c}T e=t \text { i:o } \\
5\end{array}$} \\
\hline $\begin{array}{c}\text { Depth } \\
\mathrm{mm}\end{array}$ & $\mathrm{IV}$ & $\begin{array}{l}\text { Depth } \\
m \mathbf{m}\end{array}$ & IIV & $\underset{\mathrm{mm}}{\text { Depth }}$ & $\mathrm{HV}$ & $\begin{array}{l}\text { Depth } \\
\text { mam }\end{array}$ & EV & $\underset{\mathrm{mm}}{D \in \mathrm{p}^{\mathrm{th}}}$ & $\mathrm{EV}$ \\
\hline .203 & $\therefore \& 2$ & .152 & 533 & .279 & 551 & .203 & 533 & .228 & $5 y 1$ \\
\hline .355 & 482 & .503 & 563 & .355 & 498 & .279 & 551 & .355 & 498 \\
\hline .584 & 467 & .584 & 503 & .584 & 498 & .355 & 563 & .584 & 467 \\
\hline .787 & 467 & .312 & 600 & .685 & 498 & .605 & 533 & .812 & 434 \\
\hline 1.244 & 439 & $1.2 \times 5$ & 467 & .990 & 439 & 1.160 & 533 & 1.244 & 462 \\
\hline 1.353 & 425 & 1.794 & 439 & 1.676 & 348 & 1.244 & 498 & 1.676 & 390 \\
\hline 1.676 & 305 & 2.032 & 251 & 1.955 & 348 & 1.600 & 467 & 1.955 & 348 \\
\hline 2.032 & 297 & 2.540 & 251 & 2.302 & 263 & 1.955 & 305 & 2.794 & 263 \\
\hline 2.540 & 245 & 3.303 & 229 & 3.302 & $25]$ & 2.794 & 263 & 3.302 & 251 \\
\hline $2.794^{\circ}$ & ży & 3.556 & 224 & 3.556 & 2229 & 3.302 & 251 & 3.799 & 224 \\
\hline
\end{tabular}

Oxy-acetylene Helding I Layer Devosit _._. Nacro Hardines.s.

tajo 42

\begin{tabular}{|c|c|c|c|c|c|c|c|c|c|}
\hline \multicolumn{2}{|c|}{$\begin{array}{c}\text { Test } 1: 0 \\
1\end{array}$} & \multicolumn{2}{|c|}{$\begin{array}{r}\text { Test No } \\
2\end{array}$} & \multicolumn{2}{|c|}{$\begin{array}{c}\text { Test io } \\
3\end{array}$} & \multicolumn{2}{|c|}{$\begin{array}{c}\text { Test No } \\
4\end{array}$} & \multicolumn{2}{|c|}{$\begin{array}{c}\text { Test No } \\
5\end{array}$} \\
\hline $\begin{array}{l}\text { Nepth } \\
\mathrm{mm}\end{array}$ & $\mathrm{HV}$ & $\operatorname{meoth}_{\text {min }}$ & LiV & $\underset{\text { mentin }}{\text { Destin }}$ & $\mathrm{HV}$ & $\underset{m m}{\text { Depth }}$ & $\mathrm{HV}$ & Depth & $\mathrm{iV}$ \\
\hline .1uI & 591 & .101 & jyI & .203 & 571 & .203 & 453 & .152 & 636 \\
\hline .228 & 533 & .203 & 571 & .301 & 515 & .257 & 515 & .279 & 636 \\
\hline .508 & 660 & .381 & 591 & .5003 & 613 & .687 & 351 & .508 & 686 \\
\hline .812 & 660 & .635 & 686 & .736 & $6 \sigma 0$ & 1.219 & 515 & .838 & 772 \\
\hline 1.295 & 660 & 1.143 & 613 & 1.193 & 636 & 1.676 & 439 & 1.270 & 613 \\
\hline 1.955 & 498 & 1.676 & 013 & 1.955 & 636 & 2.032 & 498 & 1.600 & 426 \\
\hline 2.794 & 467 & 2.413 & 453 & 2.514 & 401 & 2.540 & 551 & 2.794 & 390 \\
\hline 3.048 & 297 & 2.794 & 297 & 3.048 & 305 & 2.794 & 515 & 3.064 & 358 \\
\hline 3.302 & 251 & 3.302 & 257 & 3.556 & 269 & 3.556 & 269 & 3.810 & 313 \\
\hline 4.064 & 229 & 4.064 & 224 & 4.064 & 251 & $4 \cdot 318$ & 234 & $4 \cdot 318$ & 245 \\
\hline
\end{tabular}

Oxy-acetylene :

iacro ilardness 


\begin{tabular}{|c|c|c|c|c|c|c|c|c|c|}
\hline \multicolumn{2}{|c|}{$\frac{\mathrm{T} e s t}{I}$} & \multicolumn{2}{|c|}{$\underset{\bar{C}}{\text { 'ì }}$} & \multicolumn{2}{|c|}{$\begin{array}{c}\text { Test io } \\
3\end{array}$} & \multicolumn{2}{|c|}{$\begin{array}{c}\text { Test ino } \\
4\end{array}$} & \multicolumn{2}{|c|}{ Test } \\
\hline $\begin{array}{l}\text { Jepth } \\
\text { mm }\end{array}$ & $\because V$ & $\begin{array}{l}\text { Dejth } \\
\mathrm{mm}\end{array}$ & $\mathrm{IVV}$ & $\begin{array}{c}\text { Deptin } \\
\mathrm{mm}\end{array}$ & $\mathrm{EV}$ & $\begin{array}{c}\text { Depth } \\
\text { mm }\end{array}$ & $\ddot{n} V$ & $\underset{\text { mepti }}{\text { Deptis }}$ & $\mathrm{BV}$ \\
\hline .203 & +82 & .228 & 515 & .152 & 551 & .254 & 533 &.$\ddot{257}$ & 467 \\
\hline $.35 j$ & 467 & $.27 y$ & 482 & .254 & 533 & .279 & 533 &.$\ddot{279}$ & 482 \\
\hline .498 & 4067 &. .554 & 482 & .605 & 533 & .787 & 482 & .660 & 482 \\
\hline .312 & 482 & .685 & 467 & .812 & 482 & 1.524 & 467 & .312 & 482 \\
\hline $1.160^{\circ}$ & 435 & 1.244 & 467 & 1.279 & 482 & 1.676 & 467 & 1.524 & 348 \\
\hline 1.325 & 439 & 1.752 & 439 & $1 . .5=4$ & 482 & $c .082$ & 305 & 1.600 & 348 \\
\hline 1.752 & 425 & 1.900 & 434 & 1.676 & 407 & 2.540 & 313 & 1.955 & 290 \\
\hline $2.03 z$ & ¿y? & 2.032 & 305 & 2.540 & 313 & $2.79 y$ & 313 & 2.794 & $2 \approx 4$ \\
\hline 2.794 & 214 & 2.540 & 313 & 2.799 & 214 & 3.048 & 224 & 2.900 & 224 \\
\hline 3.048 & 214 & 2.794 & $<45$ & 3.302 & 214 & 3.556 & 224 & 3.048 & 214 \\
\hline
\end{tabular}

Pungsten Inert Gas ielding 1 Layer Deposit ivacro iaraness.

Table 44

\begin{tabular}{|c|c|c|c|c|c|c|c|c|c|}
\hline \multicolumn{2}{|c|}{$\begin{array}{c}\text { ri'est No } \\
1\end{array}$} & \multicolumn{2}{|c|}{$\underset{c}{I E S L}$ ilo } & \multicolumn{2}{|c|}{$\underset{3}{\text { Test }}$} & \multicolumn{2}{|c|}{$\begin{array}{c}\text { Test ivo } \\
4\end{array}$} & \multicolumn{2}{|c|}{$\begin{array}{r}\text { Test No } \\
5\end{array}$} \\
\hline$\underset{m m}{D e p t h}$ & 萡 & $\begin{array}{c}D e_{i} \tau h \\
\mathrm{~mm}\end{array}$ & $\mathrm{BV}$ & $\begin{array}{l}\text { Dep } \mathrm{m} \Omega \\
\mathrm{mm}\end{array}$ & पY. & $\begin{array}{l}\text { Deptin } \\
\mathrm{mm}\end{array}$ & $\mathrm{FV}$ & Depth & $\mathrm{HV}$ \\
\hline.$\check{2} 28$ & 606 & .203 & 571 & .152 & 591 & $.15 \bar{c}$ & 571 & .223 & 636 \\
\hline .355 & 600 & .584 & 551 & .2228 & $5 y 1$ & .254 & 533 & .279 & 636 \\
\hline $.730^{\circ}$ & 606 & .965 & 531 & .504 & 571 & .685 & 533 & .736 & 533 \\
\hline 1.244 & 551 & 1.397 & 636 & .736 & 533 & 1.168 & 482 & 1.143 & 591 \\
\hline 1.676 & 432 & 1.828 & 551 & 1.524 & 518 & 1.600 & 515 & 1.524 & 551 \\
\hline 2.082 & 402 & $\bar{z} .260$ & 482 & 2.068 & 426 & 2.430 & 467 & 2.260 & 482 \\
\hline 2.413 & .467 & 2.540 & 467 & 2.794 & 234 & 3.048 & 313 & 2.540 & 348 \\
\hline 2.794 & 339 & 3.043 & 305 & 3.048 & 218 & 3.556 & 229 & 2.794 & 290 \\
\hline 3.048 & 251 & 3.556 & 239 & 3.556 & 216 & 4.064 & 224 & 3.048 & 283 \\
\hline 3.302 & 245 & 4.064 & 218 & 4.318 & 216 & 4.318 & y & 4.064 & 224 \\
\hline
\end{tabular}


APPENDIX 4 


\section{$\because \because A \therefore E S L I T S$}

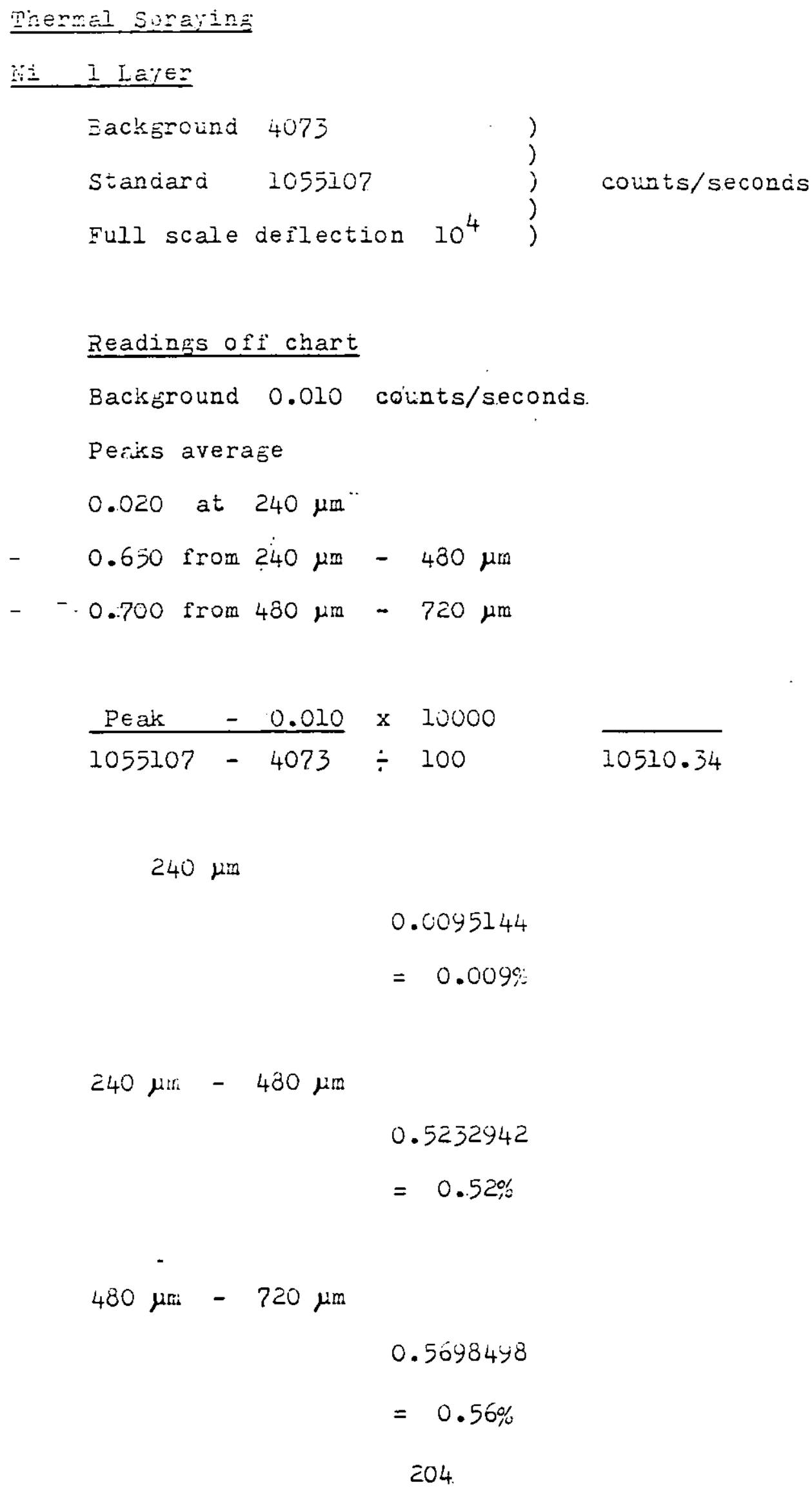




\section{Thermal Soräing}

\section{$\because \quad$ C Lajers}

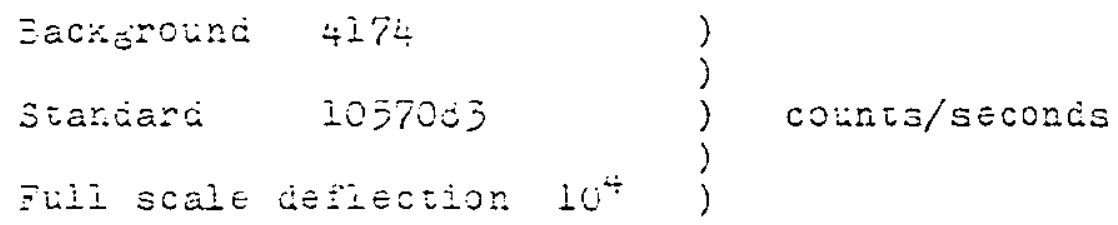

\section{Reacings off chart}

Background 0.010 counts/seconds

Peairs averā̄e

0.020 at $240 \mu \mathrm{m}$

0.833 from $240 \mu \mathrm{m} \quad-7 \check{\mathrm{m}} \mu \mathrm{m}$

$\frac{\text { Peak }-0.010}{1057083-4174 \div 10000} \div \frac{}{10529.09}$

$240 \mu \mathrm{m}$

$$
\begin{aligned}
& 0.0094974 \\
& =0.009 \%
\end{aligned}
$$

$240 \mu \mathrm{m}-720 \mu \mathrm{m}$

$$
\begin{aligned}
& 0.7816439 \\
& =0.78 \%
\end{aligned}
$$




\section{Eowcer Spray $\because \in i$ ing}

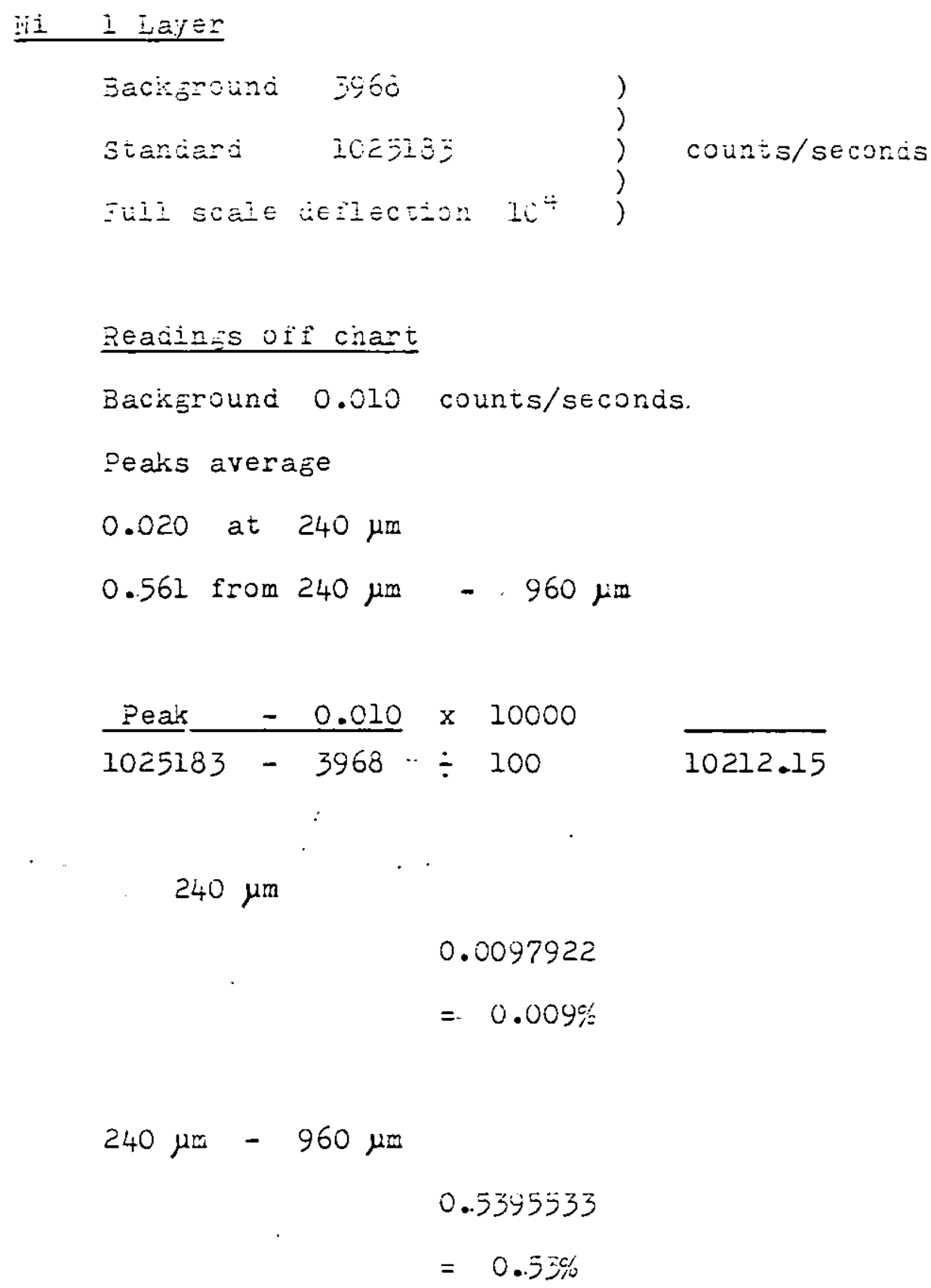




\section{Powcer Soray helcins}

Ni 2 Layers

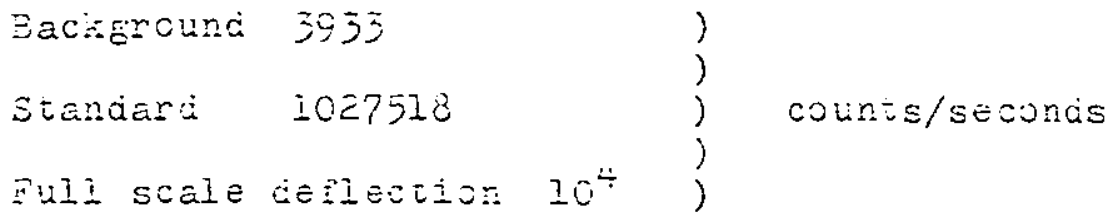

\section{Readings ofi chart}

Background 0.010 counts/seconas

Peaiss average

0.020 at $240 \mu \mathrm{m}$

0.300 from $240 \mu \mathrm{m} . .960 \mu \mathrm{m}$

$\underline{\text { Peak }-0.010} \times 10000$

$1027518-3933 \div 100 \quad \overline{10235.85}$

$240 \mu \mathrm{m}$

$$
\begin{aligned}
& 0.0097695 \\
& =0.009 \%
\end{aligned}
$$

$$
\begin{aligned}
240 \mu \mathrm{m}-900 \mu \mathrm{m} & \\
& 0.7717971 \\
& =0.77 \%
\end{aligned}
$$




\section{Cxy-acetylene :UeIding}

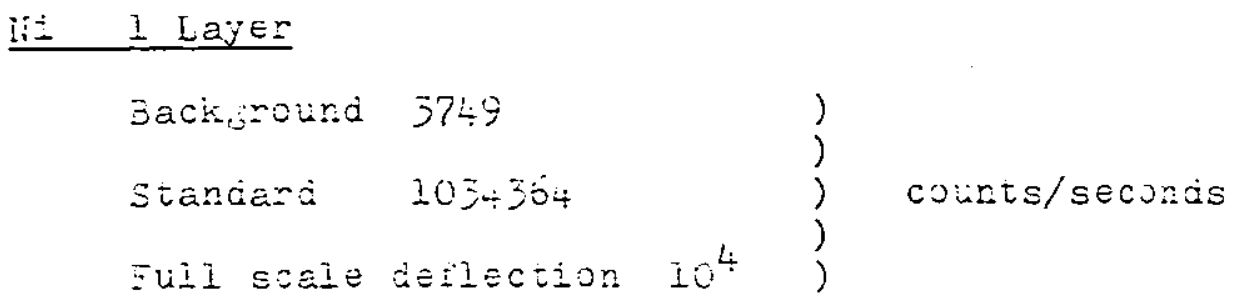

\section{Feacings of chart}

Background 0.050 counts/seconds

Feaiss averaöe

0.075 at $240 \mu m$

0.500 from $240 \mu \mathrm{m}-480 \mu \mathrm{m}$

0.550 from $480 \mu \mathrm{m}-960 \mu \mathrm{m}$

$\frac{\text { Peak }-0.050}{1034364 \ldots 37.49} \div 10000 \quad \overline{10306.15}$

$240 \mu \mathrm{m}$

$$
\begin{aligned}
& 0.0242573 \\
& =0.02 \%
\end{aligned}
$$

$240 \mu \mathrm{m}-480 \mu \mathrm{m}$

$$
\begin{aligned}
& 0.4366324 \\
& =0.430 \%
\end{aligned}
$$

$430 \mu \mathrm{m} \quad-960 \mu \mathrm{m}$

$$
0.4851472
$$$$
=0.48 \%
$$ 
Oxy-acetylene :eldins

$\underline{\text { Wi } \quad \text { L Layers }}$

Eackeround 4402

Stanciard 1151205

Fuli scaie de

coures/seconds

Readings ofi chart

Background $10^{4}$ counts/seconds.

Peaks average

0.075 at $240 \mu$

0.667 from $240 \mu \mathrm{m}-480 \mu \mathrm{m}$

0.720 from $480 \mu \mathrm{m}-960 \mu \mathrm{m}$

$240 \mu \mathrm{m}$

0.0217997

$=0.02 \%$

$240 \mu \mathrm{m}-480 \mu \mathrm{m}$

0.5380174

$=0.53 \%$

$480 \mu \mathrm{m}-960 \mu \mathrm{m}$

$0.584<328$

$=0.58 \%$ 
TG : : I I ing

I I Layer

Eaçeround $40 I I$

Stansard 10250EI

$\operatorname{count} \delta / \operatorname{secondis}$

Fuí scaie ciefiection iot)

\section{Readings of chart}

Background 0.010 counts/seconds

Pears. average

0.056 at $240 \mu \mathrm{m}$

0.450 from $240 \mu m-400 \mu m$

0.500 from $480 \mu m-960 \mu m$

$240 \mu \mathrm{m}$

0.0450534

$=0.04 \%$

$240 \mu m-480 \mu m$

0.3063718

$=0.38 \%$

$480 \mu m-960 \mu m$

$$
\begin{aligned}
& 0.44074 \\
& =0.44 \%
\end{aligned}
$$


TIG :

ii E Iayers

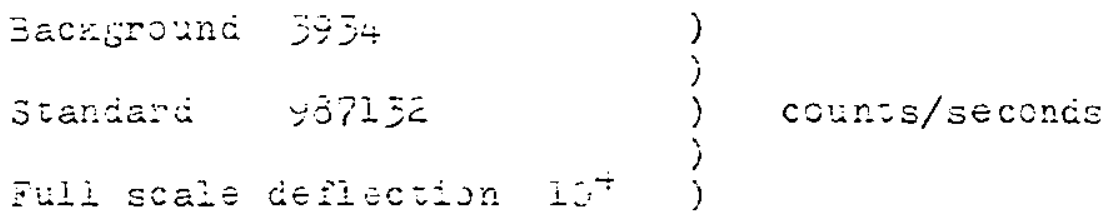

Zeadings ofic chart

Baciground 0.010 counts/seconds

Peairs average

0.055 at $240 \mu \mathrm{m}$

0.500 from $240 \mu \mathrm{m}-480 \mu \mathrm{m}$

0.540 from $480 \mu m-960 \mu \mathrm{m}$

$\frac{\text { Peak }-0.010}{987132} \div 10000 \quad \frac{}{9331.98}$

$240 \mu \mathrm{m}$

0.045769

$=0.04 \%$

$240 \mu \mathrm{m}-480 \mu \mathrm{m}$

0.4983736

$=0.45 \%$

$480 \mu \mathrm{m}-960 \mu \mathrm{m}$

0.5390572

$=0.53 \%$ 
Thermal Suraying

Cr 1 iajer

ذackeround i $i 260$

Standard $\$ 15788$

counts/seconis

Flill scaie detiection $三 x$ ioj)

\section{Readings offeciart}

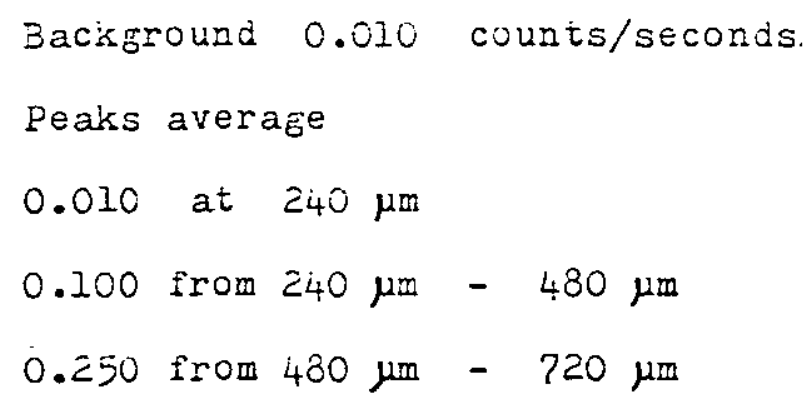

$240 \mu \mathrm{ras}$

Zero

$240 \mu \mathrm{m}-400 \mu \mathrm{m}$

$$
\begin{aligned}
& 0.0524758 \\
& =0.05 \%
\end{aligned}
$$

$480 \mu \mathrm{m}-720 \mu \mathrm{m}$

0.1399357

$=0.13 \%$ 


\section{Thermal spraying}

\section{2 Lajers}

Jackgrounc $i z こ 0$

Standara ji7j7a

counts/seconcis

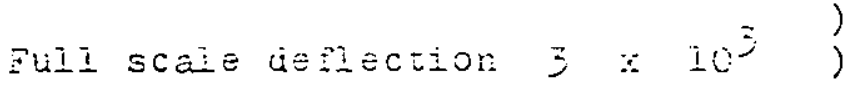

Feacines off crart

Background 0.010 counts/seconds

Peaks average

0.010 at $240 \mu \mathrm{m}$

0.250 from $240 \mu \mathrm{m}-480 \mu \mathrm{m}$

0.350 from $480 \mu \mathrm{m}-720 \mu \mathrm{m}$

Peak $-0.010^{\circ} \times 3000$

$517572-1220 \div 100$

5163.52

$240 \mu \mathrm{m}$

$$
\text { Zero }
$$

$240 \mu \mathrm{m}-480 \mu \mathrm{m}$

$$
\begin{aligned}
& 0.1394397 \\
& =0.13 \%
\end{aligned}
$$

$480 \mu m-720 \mu m$

$$
\begin{aligned}
& 0.1742997 \\
& =0.17 \%
\end{aligned}
$$


Powcien sonay ateicing

Cr I iajer

Jackground 1171

Standara $3014 \div 0$

counts/secondis

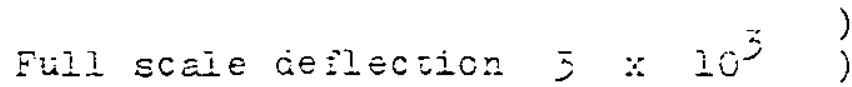

\section{Reacings of i chart}

Background 0.010 counts/seconds

Peaks average

0.010 at $240 \mathrm{pm}$

0.100 from $240 \mu \mathrm{m}-480 \mu \mathrm{m}$

0.250 from $480 \mu \mathrm{m}-960 \mu \mathrm{m}$

$\frac{\text { Peak }-0.010}{501440 \times-1171} \div 100$

$240 \mu \mathrm{m}$

Zero

$240 \mu \mathrm{m}-480 \mu \mathrm{m}$

0.0539709

$=0.05 \%$

$480 \mu m-960 \mu m$

$$
\begin{aligned}
& 0.1439225 \\
& =0.14 \%
\end{aligned}
$$




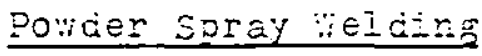

L= Z Layers

Eackgrounc Iig?

Stantarci $\quad 305158$

countsiseconds

Fuil scaie deilection $; x$ ioj)

\section{Readings off chart}

Eacikground 0.010 counts/seconds.

Peaks average

0.010 at $240 \mu \mathrm{m}$

0.200 from $240 \mu \mathrm{m}-480 \mu \mathrm{m}$

0.350 from $480 \mu \mathrm{m}-960 \mu \mathrm{m}$

$\frac{\text { Peak }-0.010}{503138 \times 3000}$

$240 \mu \mathrm{m}$

$$
\text { Zero }
$$

$240 \mu \mathrm{m}-480 \mu \mathrm{m}$

$$
\begin{aligned}
& 0.1135591 \\
& =0.11 \%
\end{aligned}
$$

$480 \mu \mathrm{m}-960 \mu \mathrm{m}$

$$
\begin{aligned}
& 0.2032111 \\
& =0.20 \%
\end{aligned}
$$


Oxy-acetylene $: \because e l$ ding

\section{Cr 1 iajer}

Eackground $144 \div$

Stanciarc $6 \% \equiv 7 \geqslant 0$

Ful scaie de Election $\left.3 \times 10^{j}\right)$

\section{Peadings off chart}

Bacisground 0.050 counts/seconds

Peaks average

0.075 at $240 \mu \mathrm{m}$

0.150 from $240 \mu \mathrm{m}-480 \mu \mathrm{m}$

0.300 from $480 \mu \mathrm{m}-960 \mu \mathrm{m}$

$240 \mu \mathrm{m}$

0.0118239

$=0.01 \%$

$240 \mu m-480 \mu m$

$$
\begin{aligned}
& 0.0472957 \\
& =0.04 \%
\end{aligned}
$$

$480 \mu \mathrm{m}-960 \mu \mathrm{m}$

$$
0.1182394
$$

$=0.11 \%$ 


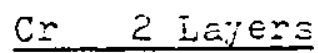

Eackground $130 \div$

Standard $97 \div 054$

counis/seconis

FuiI scaie cieriection $\equiv \because 10^{j}$ )

\section{Readings off crart}

Background 0.050 counts/seconds

Peaks average

0.075 at $240 \mu \mathrm{m}$

0.200 from $240 \mu \mathrm{m}-480 \mu \mathrm{m}$

0.310 from $480 \mu \mathrm{m}-960 \mu \mathrm{m}$

$\frac{\text { Peak }-0.050}{574094 \times 1304} \div 3000$

$$
240 \mu \mathrm{m}
$$$$
0.0130938
$$$$
=0.01 \%
$$

$240 \mu \mathrm{m}-480 \mu \mathrm{m}$

$$
\begin{aligned}
& 0.0785628 \\
& =0.07 \%
\end{aligned}
$$

$480 \mu m-960 \mu m$

$$
\begin{aligned}
& 0.1361755 \\
& =0.13 \%
\end{aligned}
$$




\section{TIG :..eiding}

\section{Cr I Layer}

\begin{tabular}{|c|c|c|}
\hline Eackerouna & 1347 & \\
\hline Standara & $63 \div 647$ & counta/secords \\
\hline
\end{tabular}

\section{Reacings off chart}

Eackgrolind 0.050 counts/seconds

Peaks average

0.200 at $240 \mu \mathrm{m}$

0.250 from $240 \mu \mathrm{m}-480 \mu \mathrm{m}$

0.500 from $480 \mu m-960 \mu m$

$240 \mu \mathrm{m}$

$$
\begin{aligned}
& 0.0236854 \\
& =0.02 \%
\end{aligned}
$$

$$
\begin{aligned}
240 \mu \mathrm{m}-480 \mu \mathrm{m} & \\
& 0.0515806 \\
& =0.03 \%
\end{aligned}
$$

$$
\begin{aligned}
480 \mu \mathrm{m}-960 \mu \mathrm{m} & \\
& 0.0710563 \\
& =0.07 \%
\end{aligned}
$$


TIG :

Cr 2 Layers

Eact:ground $116 ́ 1$

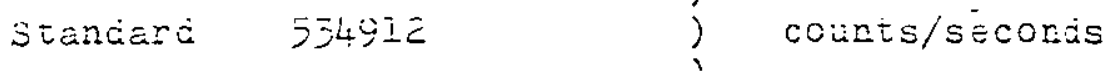

Ful soaie defiection Iij

Reavings OP̃ chart

Background 0.050 count $s /$ seconds

Peałs average

0.200 at $240 \mu \mathrm{m}$

0.300 from $240 \mu \mathrm{m}-480 \mu \mathrm{m}$

0.650 from $480 \mu m-960 \mu m$

$\frac{\text { Peak }-0.050}{534912-1161} \times 1000$

5337.51

$240 \mu \mathrm{m}$

$$
\begin{aligned}
& 0.0231029 \\
& =0.02 \%
\end{aligned}
$$

$240 \mu \mathrm{m}-480 \mu \mathrm{m}$

0.0468383

$=0.04 \%$

$480 \mu m-960 \mu m$

0.1124119

$=0.11 \%$ 


\section{Thernal Sorayins}

\section{Si I Layer}

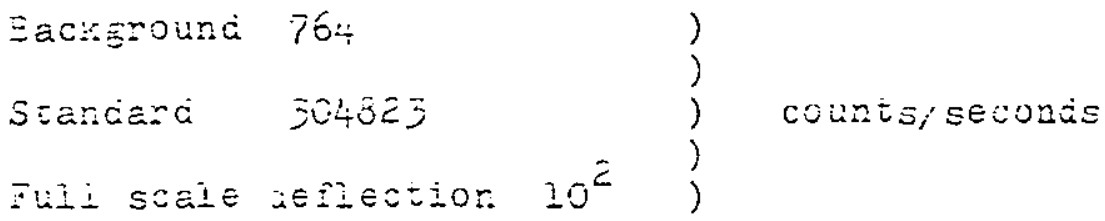

\section{Readinss off chart}

Background 0.120 counts/seconds

Peaks. average

0.455 at $240 \mu \mathrm{m}$

0.600 from $240 \mu \mathrm{m}-480 \mu \mathrm{m}$

0.710 from $480 \mu m-720 \mu m$

$240 \mu \mathrm{m}$

$$
\begin{aligned}
& 0.0110175 \\
& =0.01 \%
\end{aligned}
$$

$240 \mu \mathrm{m}-480 \mu \mathrm{m}$

0.0157864

$=0.01 \%$

$$
\begin{aligned}
480 \mu \mathrm{m}-720 \mu \mathrm{m} & \\
& 0.0194041 \\
& =0.01 \%
\end{aligned}
$$




\section{lhermai joraying}

\section{Si_z Lajers}

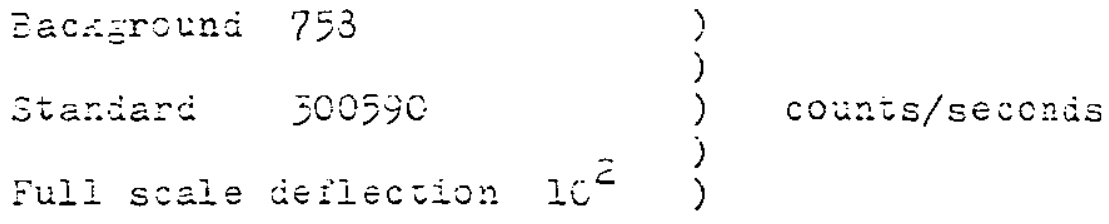

\section{Teadings ofi chart}

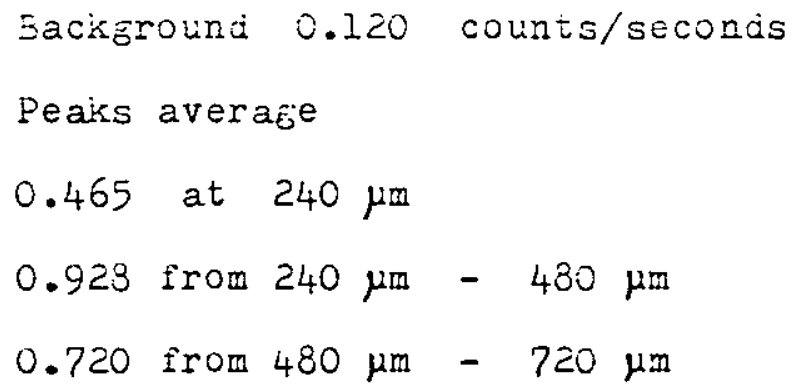

$\frac{\text { Peaik }-0.120}{300590-758 \div 100} \div 100 \quad \frac{2998.32}{}$

$240 \mathrm{jin}$

$$
\begin{aligned}
& 0.0115064 \\
& =0.01 \%
\end{aligned}
$$

$240 \mu \mathrm{m}-480 \mu \mathrm{m}$

$$
\begin{aligned}
& 0.0269484 \\
& =0.02 \%
\end{aligned}
$$

$$
\begin{aligned}
480 \mu \mathrm{m}-720 \mu \mathrm{m} & \\
& 0.0200112 \\
& =0.02 \%
\end{aligned}
$$




\section{Powder Soray :Elding}

\section{SI 2 Layers}

$\begin{array}{lll}\text { Eackground } 749 & \text { ) } \\ \text { Stancard } 306347 & \text { ) counisiseconds } \\ \text { Full scaie detlection } 10^{j} \text { ) } & \end{array}$

\section{Readings off chart}

Backgrolind 0.120 counts/seconds

Peaks average

0.400 at $240 \mu \mathrm{m}$

0.740 from $240 \mu \mathrm{m}-480 \mu \mathrm{m}$

0.740 from $480 \mu m-960 \mu m$

$\frac{\text { Peak }-0.120}{306847-749} \div 100 \quad \frac{}{3060.98}$

$240 \mu m$

0.0091473

$=0.005 \%$

$240 \mu \mathrm{m}-400 \mu \mathrm{m}$

$$
0.0202549
$$$$
=0.02 \%
$$

$480 \mu \mathrm{m}-960 \mu \mathrm{m}$

$$
\begin{aligned}
& 0.0202549 \\
& =0.02 \%
\end{aligned}
$$


Ory-acetyiene : aejoinz

\section{$\underline{\text { Si I I Iarer }}$}

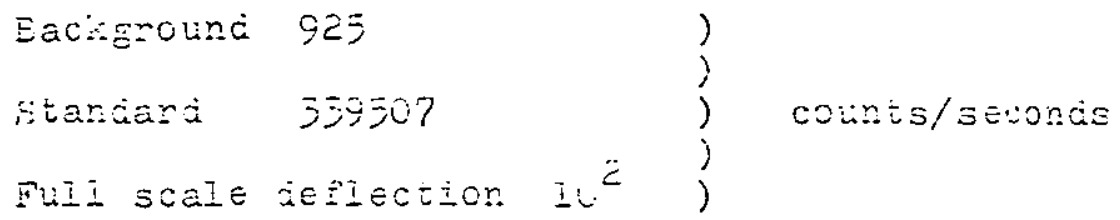

\section{Reacings of: ciart}

Backeround 0.140 counts/seconds

Peaks average

0.420 at $240 \mu \mathrm{m}$

0.567 from $240 \mu \mathrm{m}-480 \mu \mathrm{m}$

0.800 from $480 \mu \mathrm{m}-960 \mu \mathrm{m}$

$\frac{\text { Feak }-0.140}{339507-925 \div 100} \div 100 \quad \overline{3585.82}$

$240 \mu \mathrm{m}$

0.0082697

$=0.008 \%$

$$
\begin{aligned}
240 \mu \mathrm{m}-400 \mu \mathrm{m} & \\
& 0.0126114 \\
& =0.01 \%
\end{aligned}
$$

$480 \mu \mathrm{m}-960 \mu \mathrm{m}$

0.019493

$=0.01 \mathrm{c}$ 
Oxy-acetyiere ‥ eldirz

\section{$\underline{B \quad z i a j e r s}$}

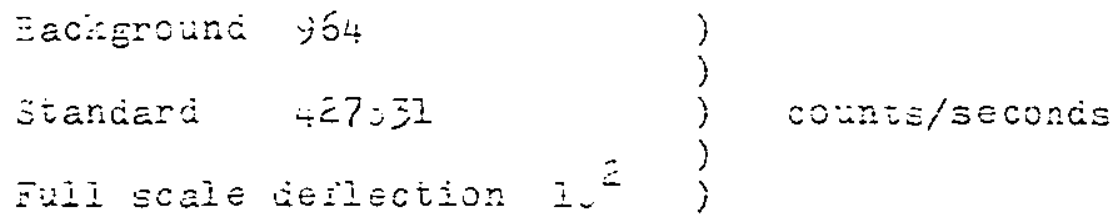

Eeadings off chart

Eackground 0.120 counts/seconas

Peaks averase

0.500 at $240 \mu \mathrm{m}$

0.980 from $240 \mu \mathrm{m}-480 \mu \mathrm{m}$

0.980 from $480 \mu \mathrm{m}-960 \mu \mathrm{m}$

$\frac{\text { Peak }-0.120}{427831-.964 .} \div 100$

4268.67

$240 \mu \mathrm{m}$

0.008902

$240 \mu m-480 \mu m$

0.0201467

$=0.02 \%$

$430 \mu m-960 \mu m$

0.0201467

$=0.02 \%$ 
TIG …elains

Si 1 iayer

Bacisound 30

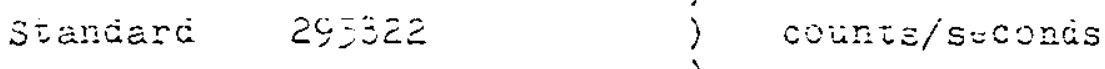

Till scaie derection io?

Reacings ofi chart

Backeround 0.140 counts/seconcis

Peaks average

0.520 at $240 \mu \mathrm{m}$

0.531 from $240 \mu \mathrm{m}-430 \mu \mathrm{m}$

0.580 from $480 \mu \mathrm{m}-960 \mu \mathrm{m}$

$\frac{\text { Peak }-0.140}{293822 \times 309 \div 100}$

$2930.13=$

$240 \mu \mathrm{m}$

$$
\begin{aligned}
& 0.0129692 \\
& =0.01 \%
\end{aligned}
$$

$240 \mu \mathrm{m}-430 \mu \mathrm{m}$

$$
\begin{aligned}
& 0.0135441 \\
& =0.01 \%
\end{aligned}
$$

$480 \mu \mathrm{m}-960 \mu \mathrm{m}$

0.0150163

$=0.01 \%$ 
TIG :.EICIDE

\section{$\underline{3+\quad 2 \text { Laters }}$}

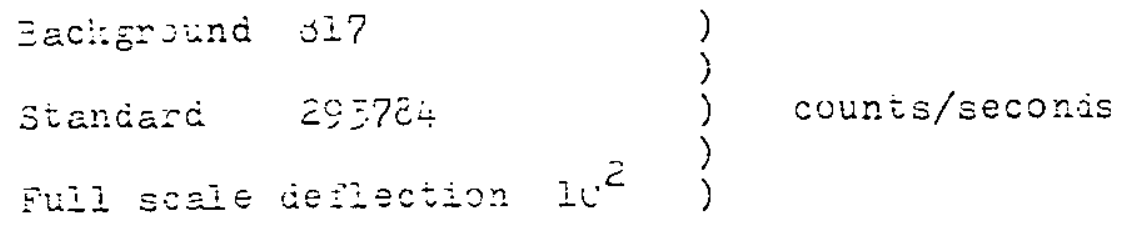




\section{Thermai Suraying}

Fe I Lajizen

Eacispound $246 j$

Stardard 847505 ) colnis/seconds

TuI scaie detecion $10^{4}$;

\section{Readings of i chart}

Eakcground 0.010 counts/seconds

Peaks average

0.835 at $240 \mu \mathrm{m}$

0.050 from $240 \mu \mathrm{m}-720 \mu \mathrm{m}$

$\frac{p}{847385-2463-0.010} \div 10000$

8449.22

$$
240 \mu \mathrm{m}
$$

$$
\begin{aligned}
& 0.9764214 \\
& =0.97 \%
\end{aligned}
$$

$240 \mu \mathrm{m}-720 \mu \mathrm{m}$

$$
\begin{aligned}
& 0.0473416 \\
& =0.04 \%
\end{aligned}
$$


Whermal Drraying

Ee ziayers

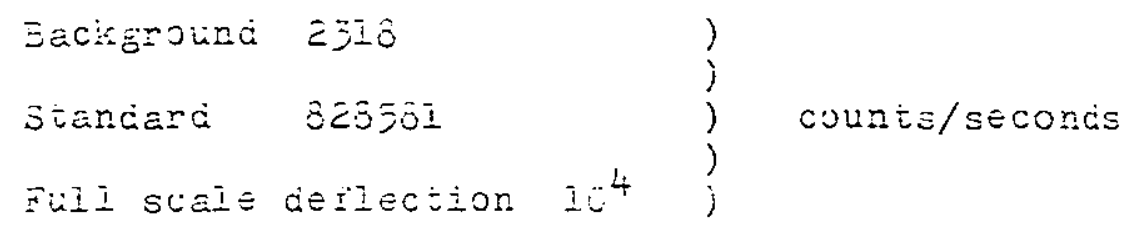

Eeadins oif crart

Bacigrolind 0.010 colints/seconds

Peaks average

0.793 . at $240 \mu \mathrm{m}$

0.050 from $240 \mu \mathrm{m}-480 \mu \mathrm{m}$

0.038 from $480 \mu \mathrm{m}-720 \mu \mathrm{m}$

Peak - $0.010{ }^{\circ} \times 10000$

$828581-.2318 \div 100 \quad 8262.63$

$240 \mu \mathrm{m}$

0.9476401

$=0.94 \%$

$240 \mu \mathrm{m}-480 \mu \mathrm{m}$

0.0484107

$=0.04 \%$

$480 \mathrm{\mu m} \mathrm{-} 720 \mathrm{\mu m}$

0.0338875

$=0.03 \%$ 


\section{Dowden Soray Hejdag}

Ee I Iajer

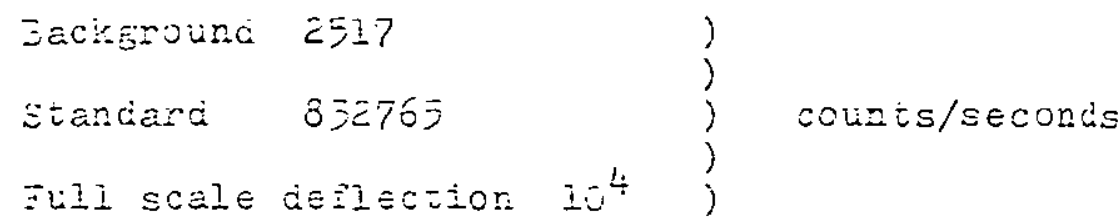

\section{reacings ofi chart}

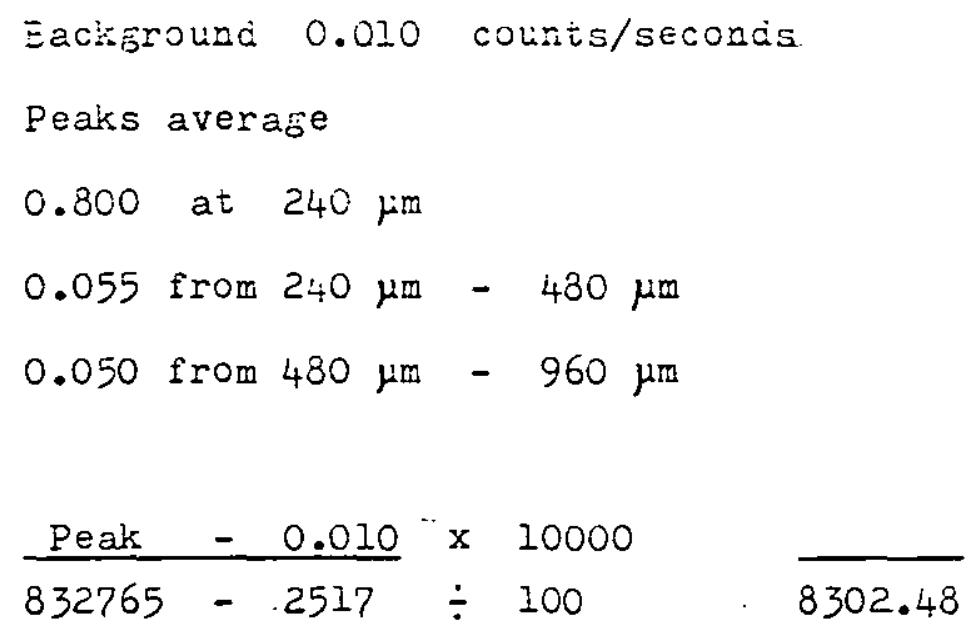




\section{Poude: Spray UeIding}

\section{Fe z Layers}

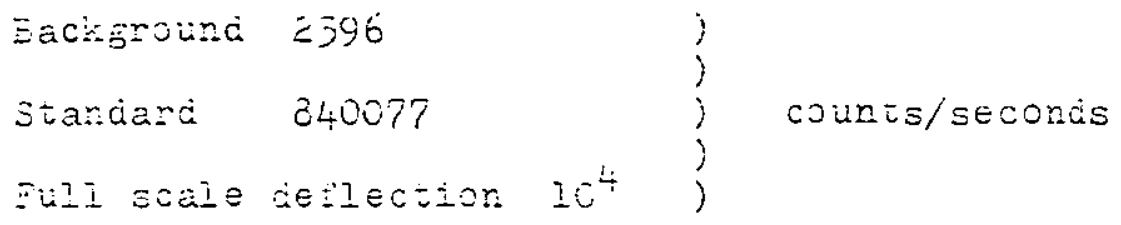

\section{Feacings ổ chart}

Background 0.010 colints/seconds

Peaks averäe

$$
\begin{aligned}
& 0.310 \text { at } 240 \mu \mathrm{m} \\
& 0.050 \text { from } 240 \mu \mathrm{m}-480 \mu \mathrm{m} \\
& 0.040 \text { from } 480 \mu \mathrm{m}-960 \mu \mathrm{m}
\end{aligned}
$$

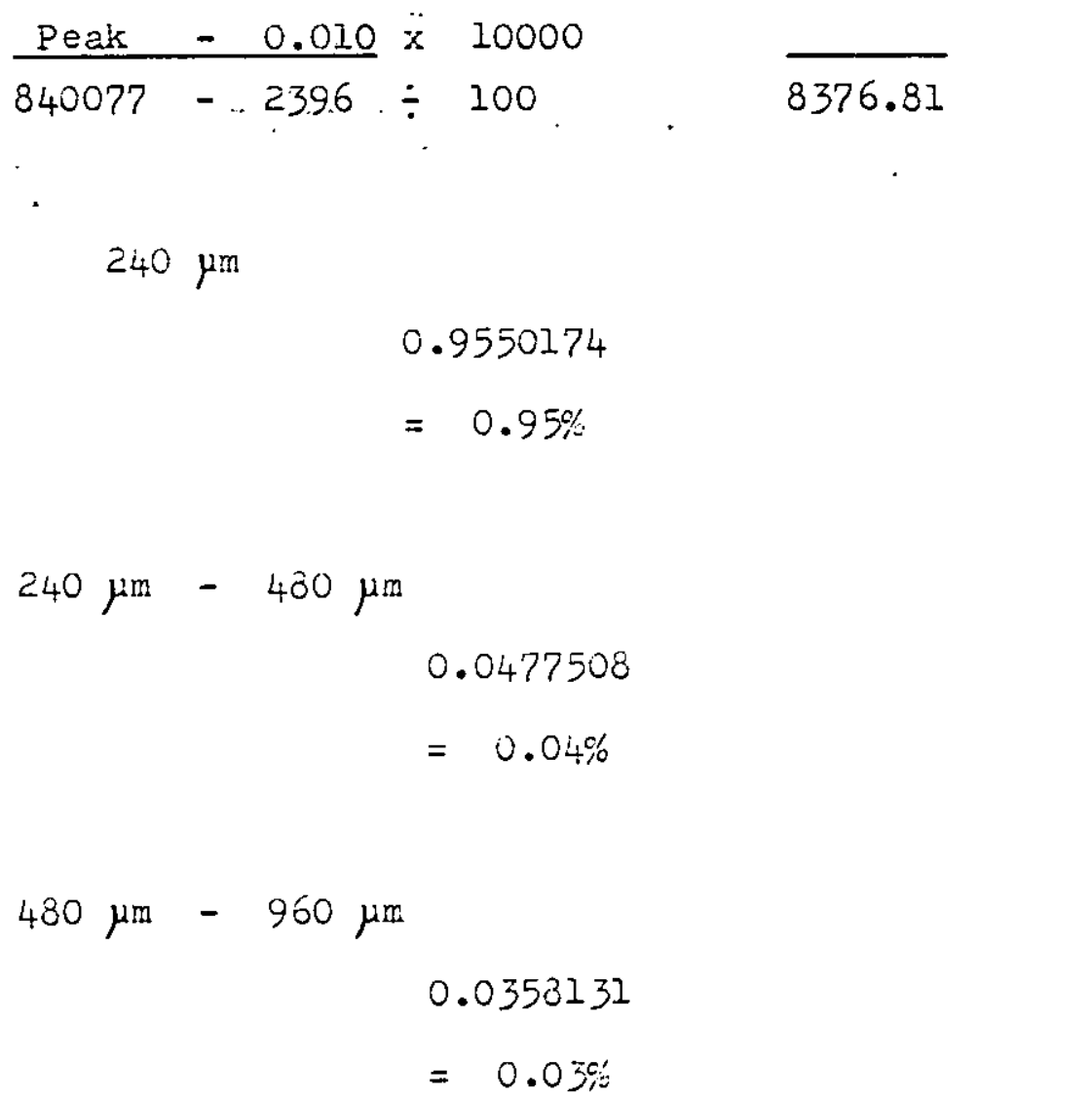


Ox-acetyiene $\because \in$ iding

\section{FE 1 iayer}

\begin{tabular}{|c|c|}
\hline Eackzround & 22509 \\
\hline Stancàád & 1080336 \\
\hline
\end{tabular}

Reacins off chart

Background 0.060 counts/seconds

Peaks. average

0.745 at $240 \mathrm{Hm}$

0.135 from $240 \mu \mathrm{m}-430 \mu \mathrm{m}$

0.120 from $480 \mu m-960 \mu m$

$\begin{array}{llll}\text { Peak }-0.060 & \\ 1088886-22589 & -15000 & \\ 10662.97\end{array}$

$$
\begin{array}{rl}
240 \mu \mathrm{m} & 0.9636152 \\
& =0.96 \% \\
240 \mu \mathrm{m}-480 \mu \mathrm{m} & \cdot \\
& 0.1055053 \\
& =0.10 \% \\
480 \mathrm{\mu m}-960 \mu \mathrm{m} & \\
& 0.0844042 \\
& =0.08 \%
\end{array}
$$




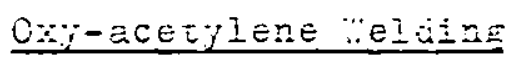

\section{Fe z iayers}

\begin{tabular}{|c|c|c|}
\hline Fackorolna & $=\$ 18$ & \\
\hline Stariam i & シこショとう & counis; secoras \\
\hline
\end{tabular}

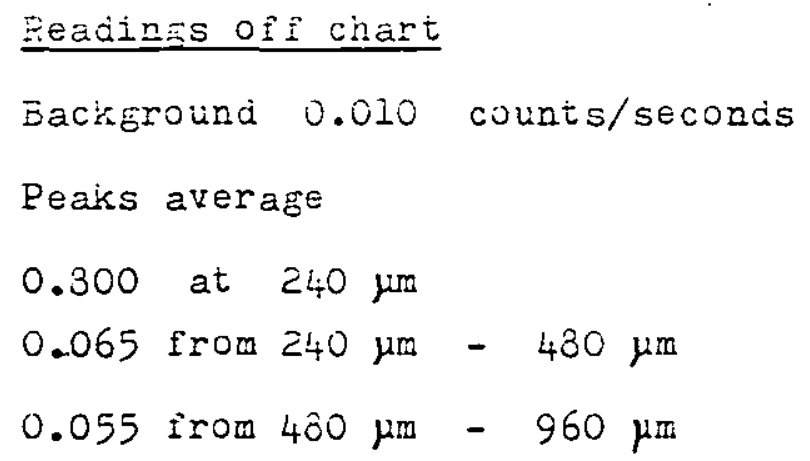

$240 \mu \mathrm{m}$

$$
\begin{aligned}
& 0.9622353 \\
& =0.96 \%
\end{aligned}
$$

$240 \mu \mathrm{m}-400 \mu \mathrm{m}$

$$
\begin{aligned}
& 0.066991 \\
& =0.06 \%
\end{aligned}
$$

$430 \mu m-960 \mu m$

$$
\begin{aligned}
& 0.0540108 \\
& =0.05 \%
\end{aligned}
$$




\section{PIG EIGing}

Fe I Lajer

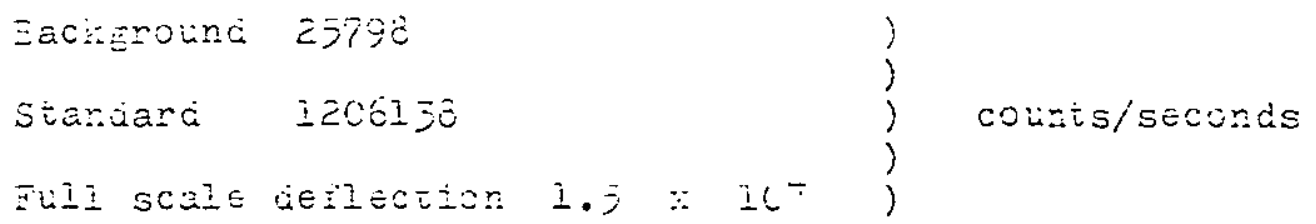

Reacinas off chart

Sackeround 0.060 counts/seconds

Peahs average

0.810 at $240 \mu \mathrm{m}$

0.200 from $240 \mu \mathrm{m}-480 \mu \mathrm{m}$

0.150 from $480 \mu \mathrm{m}-960 \mu \mathrm{m}$

$\frac{\text { Peak }-0.060}{-1206138-25798-\div .1000} \quad \overline{11803.4}$

$240 \mu \mathrm{m}$

0.9531152

$=0.95 \%$

$240 \mu \mathrm{m}-480 \mu \mathrm{m}$

0.1779148

$=0.17 \%$

$480 \mu \mathrm{m}-960 \mu \mathrm{m}$

0.1143738

$=0.11 \%$ 
TIG …eldirg

Fe z iayers

\begin{tabular}{|c|c|}
\hline Bacteground & 25908 \\
\hline$\Xi$ ¿andand & 1222574 \\
\hline
\end{tabular}

\section{Reauinss off chart}

Eackground $0.06 j$ counts/seconds

Peaks average

0.838 at $240 \mu \mathrm{m}$

0.150 from $240 \mu \mathrm{m}-480 \mu \mathrm{m}$

0.130 from $480 \mu m-960 \mu m$

Peak - $0.065 \times 15000$

$1222574.25988 \div \div 100$

$240 \mu \mathrm{m}$

$$
\begin{aligned}
& 0.9690063 \\
& =0.96 \%
\end{aligned}
$$

$$
\begin{aligned}
240 \mu \mathrm{m}-480 \mu \mathrm{m} & \\
& 0.1065531 \\
& =0.10 \% \\
480 \mu \mathrm{m}-960 \mu \mathrm{rm} & \\
& 0.0814818 \\
& =0.08 \%
\end{aligned}
$$


APPENDIX 5

Y. 
STATISTICAL ANALYSIS OF UEAR AND SURFACE HARDNESS TEST RESULTS

Nethod: The Standard Error of the Difference between Sample Means.

The research worker can tell whether the difference between two experiments is a chance difference, arising merely firom the random selection of samples from the same population, or whether the difference signifies a real difïerence between the populations represented oy the samples by calculating the standard error of the mean.

Just as the standard error of tine mean is the standard deviation of the distribution of sample means, so the standard error of the difference is the standard deviation of the distribution of the differences between sample means.

To calculate the standard error, first calculate the variance of the distribution of the differences.

$$
\operatorname{var}=\sigma^{2}
$$

Similarly, the variance of tine distribution of sample means may be expressed:

$$
\operatorname{Var} \bar{x}=\frac{\sigma^{2}}{n}
$$

It may also be shown mathematically that the variance of the difference of two independent variables is equal to the sum of their individual variances. Thus:

$$
\operatorname{Var}\left(\bar{x}_{1}-\bar{x}_{2}\right)=\frac{\sigma^{2}}{n_{1}}+\frac{\sigma 2^{2}}{n_{2}}
$$

The standard deviation for the distribution of the differences is equal to the square root of the variance 


$$
=\sqrt{\frac{\sigma^{2}}{n_{1}^{2}}+\frac{62^{2}}{n_{2}}}
$$

and this is known as the standard error of the mean.

The difference between the two sample means is then measured against the standard error. If the difference between the means exceeds three times the standard error of the difference, such a difference woula indicate that there is a significant difference between the populations from wich the samples were drawn. 
